Aline PRADO Silva

\title{
LEGITIMIDADE E DECISÃO: A CONSTRUÇÃO DO JULGAMENTO DOS CASOS DIFÍCEIS PELA TEORIA DA DECISÃO JUDICIAL DE RONALD DWORKIN
}

\author{
Dissertação de mestrado
}

Orientadora: Profa. Associada Elza Antonia Pereira Cunha Boiteux

FACULDADE DE DIREITO DA UNIVERSIDADE DE SÃO PAULO

SÃO PAULO 


\section{Aline PRADO SILVA}

\section{LEGITIMIDADE E DECISÃO: A CONSTRUÇÃO DO JULGAMENTO DOS CASOS DIFÍCEIS PELA TEORIA DA DECISÃO JUDICIAL DE RONALD DWORKIN}

Dissertação apresentada ao programa de PósGraduação stricto sensu do Departamento de Filosofia e Teoria Geral do Direito, da Faculdade de Direito da Universidade de São Paulo, visando à obtenção de título de Mestre.

Orientadora: Profa. Associada Elza Antonia Pereira Cunha Boiteux

FACULDADE DE DiREITO DA UNIVERSIDADE DE SÃo PAULO

SÃO PAULO 
Aos meus queridos pais, Janete e Carlos Roberto, por tudo, qualquer palavra reduziria o que eles representam para mim.

A Rafael por toda paciência e amor, especialmente, nos dias em que eu não merecia. 


\section{AgRADECIMENTOS}

Agradeço, em primeiro lugar, à Professora Elza Antonia Pereira Cunha Boiteux por sua imensa generosidade, inicialmente, por ter me aceito como orientanda e, depois, por ter me permitido vivenciar essa incrível experiência acadêmica, que é o mestrado, em todas as suas dimensões.

Agradeço aos Professores Tércio Sampaio Ferraz Junior e Orlando Villas Bôas Filho por toda a contribuição de ideias sobre o tema do presente trabalho, além das valiosas indicações bibliográficas, no exame de qualificação.

Agradeço às colegas de monitoria por ter tido a oportunidade de conviver e compartilhar o semestre ao lado de vocês, Renata, Melissa, Paula, Irinéia e Mariana. Agradeço, duplamente, a Renata por todo apoio e pela amizade que se construiu ao longo desses três anos.

Agradeço a todos aqueles que, mesmo sem terem sido lembrados nesta oportunidade, de alguma forma deram sua contribuição ao longo deste percurso. 


\section{RESUMO}

O presente trabalho tem por objetivo discutir a teoria proposta por Ronald Dworkin para resolver os casos difíceis pela perspectiva da construção da decisão judicial e da sua legitimidade. A abordagem, no que se refere à decisão, procura esclarecer o conceito de Direito para Dworkin, a teoria da decisão judicial que ele propõe, e, por fim, como se opera a decisão nos casos difíceis, de modo a abordar as etapas da interpretação e o método de Hércules; o poder discricionário do juiz; os direitos institucionais e jurídicos e a tese da única resposta certa nos casos controversos. No que se refere à legitimidade, são discutidas as questões atinentes ao modelo de Estado de Direito em referência ao papel a ser desempenhado pelos juízes; o problema da coerção nos casos controversos e a eventual violação da Democracia pela teoria proposta por Dworkin.

Palavras-chave: Ronald Dworkin; casos difíceis; integridade; decisão; legitimidade. 


\begin{abstract}
This work focuses on analyzing the Ronald Dworkin's theory on hard cases from the perspective of adjudication and legitimacy. The approach, in relation to adjudication, intends to clarify the Dworkin's concept of Law, the theory of adjudication, and, lastly, how works adjudication in hard cases, in order to enlighten the stages of interpretation and the Hercules' method; judicial discretion; institutional and legal rights and the one right answer thesis in hard cases. In relation to legitimacy, the discussion is focused on the rule of law concerning to the role that judges play; the problem of coercion on hard cases and the possible threatens to democracy that Dworkin's theory would represent.
\end{abstract}

legitimacy.

Key-words: Ronald Dworkin; hard cases; integrity; adjudication; 


\section{SUMÁRIO}

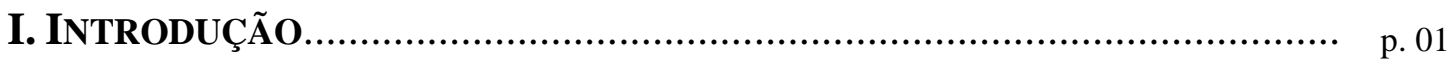

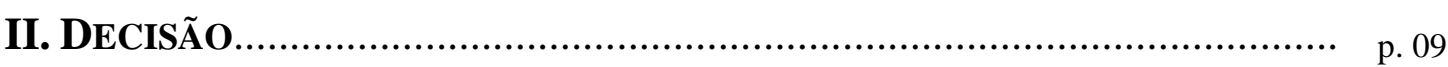

II.1. O CONCEITO DE DIREITO PARA RONALD DWORKIN................. p. p. 09

II.1.1. Direito como integridade vs. Convencionalismo e Pragmatismo Jurídico..................................................................... p. 20

II.1.2. Diálogo com o positivismo jurídico de H. L. A. Hart................ p. 36

II.1.3. Diferenças entre regras, princípios e políticas.......................... p. 51

II.2. A TEORIA DA DECISÃO JUDICIAL DE RONALD DWORKIN........... p. p. 55

II.3. A DECISÃO NOS CASOS DIFÍCEIS........................................ p. p. 69

II.3.1. Etapas da interpretação e o método de Hércules....................... p. p. 75

II.3.2. O poder discricionário do juiz............................................. p. 92

II.3.3. Direitos institucionais e jurídicos........................................... p. 98

II.3.4. Tese da única resposta certa nos casos controversos................. p. 102

II.3.4.1. Crítica dos céticos (ceticismo interno e externo)....... p. 115

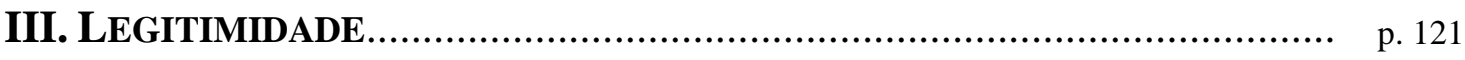

III.1. CONCEPÇÕES DE ESTADO DE DIREITO E SUAS RELAÇÕES COM O PAPEL A SER DESEMPENHADO PELOS JUÍZES............................. p. 121 
III.3. VIOLAÇÃO DA DEMOCRACIA.

III.3.1. Conceitos de Democracia: a concepção constitucional, a premissa majoritária e sua relação com as ações coletivas estatística e comunitária.

III.3.1.1. As relações do princípio da igualdade com as concepções de Democracia.

III.4. OS MODELOS DE COMUNIDAdE POLÍTICA E A QUESTÃo DA LEGITIMIDADE

V. Conclusão. p. 180 


\section{INTRODUÇÃO}

Esta dissertação tem por objeto a análise de como se devem construir os julgamentos dos casos difíceis ${ }^{1}$ pela teoria da decisão judicial de Ronald Dworkin. Para que o tema seja trabalhado, em toda a sua complexidade e envergadura, não se irá apresentar apenas a teoria da decisão judicial proposta por Dworkin, será, também, apresentada uma análise cuidadosa da legitimidade da decisão construída, nestes termos, considerando o Estado de Direito em que se vive contemporaneamente.

Destaca-se que o foco, em todos os aspectos que serão abordados ao longo deste trabalho, é o pensamento de Dworkin externado, diretamente, em suas obras. Nesse sentido, as demais doutrinas e teorias serão tratadas apenas na medida em que se façam necessárias ao esclarecimento e confrontamento com o pensamento do autor. Por essa razão, procurou-se privilegiar as citações do próprio Dworkin no corpo do texto, enquanto os seus comentadores foram citados, preponderantemente, em notas de rodapé, para que não se prejudicasse o desenvolvimento do raciocínio do autor objeto de estudo deste trabalho.

Com relação ao primeiro grande tema trabalhado nesta dissertação, a questão da decisão judicial (Capítulo II), a análise foi do macro para o micro tema. Explica-se. No caso, para que se entenda o método proposto por Dworkin para a resolução dos casos difíceis será necessário entender o que este autor entende por Direito, na medida em que isso irá delimitar o campo de ação do

\footnotetext{
1 "Os casos difíceis se apresentam, para qualquer juiz, quando sua análise preliminar não fizer prevalecer uma entre duas ou mais interpretações de uma lei ou de um julgado." (DWORKIN, Ronald. O império do direito, trad. Jefferson Luiz Camargo, São Paulo: Martins Fontes, 2007, p. 306) “(...) quando juristas competentes se dividem quanto qual a decisão se exige, porque as únicas leis ou precedentes pertinentes são ambíguos ou não há nenhuma opinião firmada com pertinência direta, ou porque o direito, por alguma razão, não está assente."(DWORKIN, Ronald. Uma questão de princípio, trad. Luís Carlos Borges, São Paulo: Martins Fontes, 2005, p. 109)
} 
juiz em suas decisões. Dentro desta temática, mostrou-se relevante a confrontação do conceito de Direito proposto por Dworkin face às duas teorias opositoras centrais, o convencionalismo e o pragmatismo jurídico (Capítulo II.1.1.). Estas duas correntes foram eleitas pelo próprio Dworkin, em seu livro $O$ Império do Direito, para confrontar com o conceito de Direito como integridade, por ele elaborado, por serem representativas quanto às posturas mais frequentes dos intérpretes do Direito na resolução dos casos difíceis.

Prosseguindo-se no aprofundamento do conceito de Direito na teoria de Dworkin, além do confrontamento com o convencionalismo e o pragmatismo jurídico, estabeleceu-se diálogo com o seu grande antagonista, nesta empreitada teórica, qual seja, o positivista H. L. A. Hart (Capítulo II.1.2.). O diálogo, dado o seu destaque, foi construído em diversas obras de Dworkin, as quais serão devidamente tratadas ao longo deste trabalho, tendo sido realçados os pontos de divergência entre os autores.

A partir dessa conceituação de Direito, passou-se a uma etapa seguinte, qual seja, a análise da teoria da decisão judicial proposta por Ronald Dworkin, a qual, diferentemente de positivistas como Hart, é parte da sua teoria do Direito. A esse respeito, cumpre ressaltar que Dworkin não pauta a discussão da sua teoria do Direito, na discussão da validade das normas, como os positivistas analíticos costumam fazer, mas concentra a sua atenção na aplicação do Direito, que para ele é um conceito interpretativo.

Com relação à aplicação do Direito, o Capítulo II.2., referente à teoria da decisão judicial, compreende as questões atinentes à construção da decisão judicial, isto é, define os elementos que se deve considerar ao julgar, o que é relevante e o que não é, bem como trata das limitações do poder do juiz ao julgar um caso controverso, além desses temas, no referido Capítulo, é 
aprofundada a questão metodológica da teoria proposta por Dworkin. Quanto à relevância dessas temáticas, destaca-se que os casos fáceis não geram controvérsia, porque a regra aplicável é clara, todavia, em um caso difícil, em que não se sabe prima facie qual a solução, deve-se desenvolver uma teoria consistente para se chegar a uma decisão, uma vez que não se admite o non liquet.

Em continuidade ao afunilamento da temática, aborda-se, especificamente, a teoria proposta por Dworkin para se resolver um caso difícil, no Capítulo II.3., para tanto são consideradas: (i) as etapas da interpretação e o método de Hércules (Capítulo II.3.1.); (ii) o poder discricionário dos juízes (Capítulo II.3.2.), com enfoque na diferença da proposta apresentada por Hart e Dworkin, para resolver os casos difíceis; (iii) os direitos institucionais e jurídicos (Capítulo II.3.3.); e, por fim, (iv) a controversa tese de uma única resposta certa nos casos difíceis (Capítulo II.3.4.). Neste último ponto, será confrontada esta tese com a forte crítica dos céticos que rejeitam com veemência essa possibilidade de única resposta certa nos casos controversos (Capítulo II.3.4.1).

Cabe ressaltar que a escolha do tema deste trabalho decorre do interesse pela construção do julgamento de casos limites, nos quais o julgador sai de sua zona de conforto (as regras expressas e os precedentes), e se insere em uma área cinzenta de dúvida sobre a melhor solução ao caso. Essa temática é cada vez mais recorrente, na medida em que os juízes, ao se depararem com um caso controverso, são por vezes acusados de serem ativistas e usurparem para si as funções constitucionalmente estabelecidas para os demais Poderes. Nesta seara, insere-se a questão da legitimidade, que é tratada no Capítulo III, cuja tônica do debate é dada pela forma como se concebe o Estado de Direito (Capítulo III.1.) e, a partir disso, desdobram-se as outras questões, como, por 
exemplo, a questão da coerção nos casos controversos (Capítulo III.2.) e a eventual violação da Democracia (Capítulo III.3.).

Pode-se dizer que o papel mais ativo assumido pelo Judiciário (sendo ele legítimo, ou não) decorre da própria concepção de Estado mais intervencionista, provedor das necessidades da população, que, para atingir suas finalidades, atribuí competências que se compartilham entre os Poderes. Isso se reflete nas normas, que deixam de ser apenas dirigidas à regulação de condutas e passam a ter caráter principiológico e finalístico, tal como afirma Mauro Cappelletti em sua obra “Juizes Legisladores?”. ${ }^{2}$ O Poder Judiciário assume, em razão de fazer parte dessa nova formulação de Estado, um papel mais ativo na realização das finalidades a que o Estado se propõe a alcançar, todavia, há de se ter cautela com o seu papel na resolução de questões políticas. ${ }^{3}$

O Poder Judiciário em face das demandas sociais, ainda que de cunho estritamente político, não atendidas pelos Poderes competentes, tende a extrapolar as suas competências constitucionais em prol de uma suposta justiça social a ser efetivada ${ }^{4}$. Todavia, o risco a que se está sujeito com um Poder Judiciário politizado é muito alto, nesse sentido, manifesta-se o professor Tércio

2 CAPPELLETTI, Mauro. Juízes Legisladores?, trad. Carlos Alberto Alvaro de Oliveira, Porto Alegre: Sérgio Antonio Fabris Editor, 1999, pp. 40-41

3 A esse respeito, o constitucionalista Paulo Bonavides ressalta que: “À concepção liberal se deve pois a delimitação de uma extensa província - a dos direitos individuais - inteiramente fora das questões políticas (as únicas excluídas do exame judicial). As questões políticas, consideradas de um ponto de vista técnico, para efeito de excluí-las do controle de constitucionalidade, são entre outras as que se alojam na faculdade discricionária, reservada aos poderes políticos, para ditar, por exemplo, as medidas de política econômica, declarar guerra, negociar a paz, estabelecer regime tributário (...), em suma, aquelas prerrogativas que, pela sua natureza mesma, podem compor o substrato de uma política ou de uma legislação, cujo teor controverso não será nunca objeto legítimo de apreciação judicial. A esfera de controle material fica porém com os juízes e os tribunais é tão-somente a dos direitos individuais, não obstante a dimensão política e a relatividade que tais direitos tomaram nas vigentes concepções de Estado social.” BONAVIDES, Paulo. Curso de Direito Constitucional. 15 ed., São Paulo: Malheiros, 2004, p. 323

4 "A Justiça limita-se a decidir sobre os direitos individuais. Quando se diz que lhe não compete resolver sobre questões políticas, o que se entende afirmar é que se não pode intrometer em assuntos, encarregados, pela Constituição, ou pelas leis, à discrição de outro poder.” DE MIRANDA, Pontes. Comentários à Constituição de 1946. $3^{\text {a }}$ ed., Tomo III, Rio de Janeiro: Editor Borsoi, 1960, p. 206 
Sampaio Ferraz Junior: "Uma Justiça politizada, ao contrário, compartilha da responsabilidade pelos resultados do uso da violência, fazendo do juiz um justiceiro e do processo um movimento na direção dos famigerados tribunais de exceção. Ou seja, a Justiça politizada arrisca-se a render-se ao marketing das opiniões, reduzindo o direito a elas, o que funciona bem no Legislativo mas que, no Judiciário, torna opaco o uso da força, conduzindo-a à banalidade e à trivialidade do jogo de interesses."

A politização desmedida conduz a um processo crescente de violação do princípio da separação dos Poderes, processo este, por meio do qual, o Judiciário assume funções, que não lhe incumbe assumir, sendo ativista e pouco reverenciador do Estado Democrático de Direito. Com relação a esta questão, destaca-se que é um grande equívoco considerar Dworkin um defensor do ativismo judicial. Ao contrário, Dworkin refuta o ativismo judicial, expressamente $^{6}$, o que é evidenciado no Capítulo III.1 e III.3., que tratam do entendimento do autor acerca do que seria o Estado de Direito, em sua teoria, e sobre eventual violação da Democracia de acordo com este modelo. O modelo de Estado de Direito proposto por Dworkin atende a essas novas demandas, porém não se baseia em uma postura ativista do juiz.

Outro ponto que merece destaque na formação deste quadro, que aqui se ilustra, foi a mudança no paradigma de Estado, que passou de Liberal, para o Estado de Bem Estar Social (welfare state), e, posteriormente, para o Estado neoliberal, marcado ainda pelo intervencionismo estatal, nas relações sociais e econômicas. As Constituições contemporâneas, além de privilegiar os direitos individuais, fruto do Estado Liberal, também, trazem em seu bojo direitos sociais, oriundos do Estado de Bem Estar Social, o que motiva em

\footnotetext{
${ }^{5}$ FERRAZ JUNIOR, Tércio Sampaio. O Judiciário frente à divisão dos Poderes: um princípio em decadência?. Revista USP - Dossiê Judiciário, São Paulo, v. 21, 1994, p. 18

${ }^{6}$ DWORKIN, Ronald. O império do direito, cit., p. 452
} 
alguma medida a postura ativista do Judiciário na efetivação desses direitos. Nesse sentido, o professor José Eduardo Faria destaca o papel do Judiciário mais intervencionista, na mudança de paradigma do Estado. Para o professor, no Estado liberal, a legitimidade centra-se nas formas que estabelecem as regras do jogo, portanto, não haveria uma preocupação com a substância das decisões políticas e jurídicas; enquanto, um Estado mais intervencionista remeteria a essa substância, na medida em que se demandaria uma aceitação generalizada do conteúdo das decisões, proferidas pela ordem vigente, dentro de uma pluralidade de interesses defendidos pelos grupos e classes sociais conflitantes. ${ }^{7}$

Como se pôde observar, essa temática sobre os limites e a legitimidade do Poder Judiciário para agir em casos controversos, que podem envolver questões de cunho político, está na ordem do dia do debate constitucional e filosófico. Tendo em vista esse cenário, que não é exclusivo da realidade brasileira, mas também ocorre em países de common law, como os Estados Unidos, Dworkin desenvolve a sua teoria da decisão judicial, que visa apresentar e fundamentar as balizas para as decisões judiciais sobre os casos difíceis. É uma teoria que não se limita a explicar o melhor método de interpretação, mas que, também, apresenta os pressupostos legitimadores desse método em uma dada comunidade política.

Pode-se questionar, a esse respeito, se a teoria desenvolvida por Dworkin aplicar-se-ia ao Brasil, que é um país de tradição romano-germânica no

7 "Na perspectiva do liberalismo jurídico-político, como vimos na seção precedente, a fórmula legitimadora de seu sistema legal não está na obtenção do consenso em torno do conteúdo de suas normas ou de decisões de política substantiva, porém no respeito unânime aos procedimentos formais que definem as regras do jogo. Já na perspectiva do Estado dito "intervencionista", a fórmula legitimadora de sua ação regulatória depende de sua eficácia tanto em promover a despolitização dos conflitos para repolitizá-los de modo controlado quanto em ampliar a prontidão generalizada para aceitação de suas decisões independentemente de seu conteúdo, permitindo-lhe assim garantir o engajamento e a mobilização dos diferentes grupos e classes sociais em torno da ordem vigente." FARIA, José Eduardo. O modelo liberal de direito e Estado. In: José Eduardo Faria (Org.), Direito e Justiça: a função social do judiciário, 3a edição, São Paulo: Editora Ática, 1997, p. 31 
que se refere ao Direito. Com relação a esta questão, deve-se destacar que o Direito brasileiro, embora provenha desta tradição, incorpora diversos institutos que mesclam os modelos romano-germânico com o anglo-saxão (common law), nesse sentido, pode-se citar que (i) o controle de constitucionalidade pode ser feito de maneira difusa no Brasil, como é no direito norte-americano, diferentemente, dos tribunais políticos dos países de tradição romanogermânica, cujo modelo de controle de constitucionalidade é apenas concentrado (e.g. França); (ii) foi introduzido o instituto da súmula vinculante pela Emenda Constitucional n. ${ }^{\circ} 45$, de 30 de dezembro de 2004, que é, claramente, uma forma de adoção do stare decisis do direito norte-americano no direito brasileiro para que um precedente judicial vincule os demais; e (iii) no direito norte-americano, os juízes não têm um poder criador tal como o legislador, como alguns poderiam imaginar; Dworkin, inclusive, refuta o papel do Judiciário, enquanto um legislador delegado, pois naquela cultura há uma forte vinculação às leis e aos precedentes (direito costumeiro) e uma rechaço à criação judicial desvinculada das decisões políticas passadas, o que será devidamente tratado ao longo deste trabalho.

Nesse sentido, uma suposta diferença considerável que haveria entre o juiz norte-americano (de tradição anglo-saxã) e o juiz brasileiro (de tradição romano-germânica) revela-se bastante atenuada, o que justifica, não apenas enquanto um apelo teórico, mas prático, do estudo da teoria da decisão judicial de Dworkin em território nacional. Ainda, destaca-se que os próprios magistrados da mais alta Corte deste país, o Supremo Tribunal Federal, referemse ao trabalho de Dworkin e a sua relevância ao Direito brasileiro, em seus votos $^{8}$, o que será devidamente evidenciado no Capítulo IV desta dissertação. 8 'Não se pode ceder, no caso, a considerações de ordem moral, exceto por uma, que, ao revés, é
indispensável: todos os indivíduos devem ser tratados com igual consideração e respeito. É esta a
base da leitura moral da Constituição propugnada por RONALD DWORKIN (Freedom's Law: The
Moral Reading of The American Constitution. Cambridge: Harvard University Press, p. 7-8), que, 
Tendo em vista todos os problemas levantados por estas questões, atinentes ao papel dos juízes no Estado de Direito contemporâneo, no que se refere ao tema da legitimidade das decisões (Capítulo III) por eles confeccionadas, serão abordadas à luz da teoria proposta por Dworkin: as concepções de Estado de Direito e suas relações com o papel a ser desempenhado pelos juízes (Capítulo III.1.); o problema da coerção nos casos controversos (Capítulo III.2.); a eventual violação da Democracia nas decisões, que versam sobre os casos controversos (Capítulo III.3.); bem como, os modelos de comunidade política associados à questão da legitimidade (Capítulo III.4.).

Por fim, como fechamento da análise, que permitirá a necessária união entre teoria e prática ${ }^{9}$, serão trabalhados alguns casos práticos difíceis, nos quais os ministros do Supremo Tribunal Federal adotaram, expressamente, em seus votos, teses de Dworkin para firmar algumas de suas posições.

mesmo tecendo argumentos sobre o constitucionalismo nos EUA, formula assertivas perfeitamente aplicáveis ao direito constitucional brasileiro." (g.n.) Voto do Ministro Carlos Ayres Britto, ADPF 132/RJ, p. 65

9 “(...) enquanto a Filosofia tende a ser uma investigação teórica. Entretanto, enquanto Direito ela é uma atividade preponderantemente prática. É por essa razão que o jusfilósofo não pode ser exclusivamente teórico como um físico, nem exclusivamente prático como um engenheiro." LAFER, Celso. A reconstrução dos direitos humanos. Um diálogo com o pensamento de Hannah Arendt. São Paulo: Cia das Letras, 1988, p. 49 


\section{DECISÃO}

\section{1. O CONCEITO DE DIREITO PARA RONALD DWORKIN}

\section{O conceito de Direito para Dworkin é interpretativo ${ }^{10}$, chegar-se-ia}

a ele interpretando, construtivamente e da melhor forma possível, a prática jurídica de uma dada comunidade política ${ }^{11}$. Essa interpretação construtiva permite a formação do conceito de Direito, enquanto um todo íntegro, que se constituiria no tempo, formando o que Dworkin denomina de romance em cadeia $^{12}$, cujos autores que compõem este enredo estariam no passado, presente

10 "O direito é um conceito interpretativo. Os juízes devem decidir o que é o direito interpretando o modo usual como os outros juízes decidiram o que é o direito. Teorias gerais do direito são, para nós, interpretações gerais da nossa própria prática judicial.” DWORKIN, Ronald. O império do direito, cit., p. 488

11 DENNIS PATTERSON critica a concepção de Dworkin de Direito, como interpretação, sob o argumento de que existe "entendimento", inclusive no Direito, o qual não carece de interpretação. Por esta visão, afirma que se todo tipo de "entendimento" carecesse de interpretação iria-se regressar ao infinito em busca dele, o que não parece a ele plausível. Para Patterson, a única forma de não cair nessa cadeia viciosa de regresso ao infinito seria por meio da assunção de que a normatividade das regras jurídicas reside na prática e não na interpretação desta: "If all understanding were interpretation, then each interpretation would itself stand in need of interpretation, and so on, infinitely regressing to infinity. This logical problem, one long ago recognized, suggest that there is something deeply wrong with assigning to interpretation a mediating role between utterances and the understanding of them. The only way out of this vicious regress is to recognize that the normativity of rule-guided behavior (e.g., law) lies not in the act of the individual (e.g., interpretation) but in a practice. Of course, Dworkin argues that law is a practice, and in this he is surely correct. He has simply misstated the role of interpretation in that practice." (PATTERSON, Dennis. Law and Truth, Oxford: Oxford University Press, 1996, p. 88) No mesmo sentido, pode-se mencionar NEIL MACCORMICK, o qual considera Dworkin um ultra-racionalista, e que essa posição o levaria à regressão ao infinito nas suas justificações: “A falácia ultra-racionalista consiste na pressuposição de que existe algum modo de estabelecer pelo raciocínio e pela reflexão uma ordem moral ou legal objetivamente válida. Contudo, qualquer tentativa de estabelecer e justificar uma ordem teórica dessa natureza simplesmente levaria a uma infinita regressão de justificações, que não é apenas semelhante, mas é o próprio caminho de regressão infinita de teorias ao qual o Hércules de Dworkin está fadado sem perceber." (MACCORMICK, Neil. Argumentação Jurídica e Teoria do Direito, São Paulo: Martins Fontes, 2006, pp. 350-351)

12 "Em tal projeto, um grupo de romancistas escreve um romance em série; cada romancista da cadeia interpreta os capítulos que recebeu para escrever um novo capítulo, que é então acrescentado ao que recebe o romancista seguinte, e assim por diante. Cada um deve escrever seu capítulo de modo a criar da melhor maneira possível o romance em elaboração, e a complexidade desta tarefa reproduz a complexidade de decidir um caso difícil de direito como integridade. O projeto literário fictício é fantástico, mas não irreconhecível. Na verdade, alguns foram escritos dessa maneira, ainda que com uma finalidade espúria, e certos jogos de salão para os fins de semana chuvosos nas casas de campo inglesas têm estrutura semelhante. As séries de televisão repetem por décadas os mesmos personagens e um mínimo de relação entre personagens e enredo, ainda que sejam escritas por 
e futuro.

Nessa ideia de romance em cadeia, Dworkin compara o Direito a um exercício literário, em que o texto passa de mãos em mãos, formando uma única história. O ponto que se coloca em foco, em um primeiro momento, é sobre os sentidos que se atribui às proposições de Direito que compõem esta história, quando o intérprete recebe o texto em mãos para dar prosseguimento ao enredo. Com as proposições claras, que não deixam dúvidas interpretativas, o intérprete continua a redigir o texto sem dificuldades, mas quando ele se depara com casos difíceis que exigem que ele recorra a proposições gerais e abstratas, como os princípios, que não indicam uma resposta imediata, fica em dúvida sobre o melhor caminho para dar continuidade à história.

De acordo com Dworkin, muitos juristas e filósofos do Direito entendem que a atividade interpretativa, quando se deparam com uma proposição geral e abstrata, deve ser empreendida na busca pela intenção dos legisladores ao positivar certa norma. Isto é, o que eles queriam dizer com as palavras que empregaram. A essa corrente pode-se denominar originalista/intenção original $^{13}$, ou psicologia de grupo $^{14}$. Esta corrente parece

diferentes grupos de autores e, inclusive, em semanas diferentes. Em nosso exemplo, contudo, espera-se que os romancistas levem mais a sério suas responsabilidades de continuidade; devem criar em conjunto, até onde for possível, um só romance unificado que seja da melhor qualidade possível." DWORKIN, Ronald. O império do direito, cit., p.276

13 "Segundo o originalismo, os grandes dispositivos da Declaração de Direitos não devem ser interpretados como exposições dos princípios morais abstratos que eles descrevem de fato, mas como referências, em código ou disfarçadas, aos pressupostos e expectativas que os próprios autores tinham acerca da correta aplicação daqueles princípios.” DWORKIN, Ronald. $O$ direito da liberdade: A leitura moral da Constituição norte-americana, trad. Marcelo Brandão Cipolla, São Paulo: Martins Fontes, 2006, pp. 19-20

14 "Mais uma vez, não ocorre aqui nenhuma suposição de que todos os juristas sensatos concordarão quanto ao que os legisladores pretendiam. Pelo contrário, os defensores do modelo centrado no repertório legislativo sabem que mesmo advogados habilidosos discordarão no que diz respeito a inferências da intenção legislativa extraídas de uma mesma prova. Insiste, não obstante, em que a questão da intenção é a pergunta certa a se fazer, pois cada juiz que a faz está, pelo menos, fazendo o melhor que pode para seguir o modelo do repertório legal e, portanto (segundo sua concepção), seguir o Estado de Direito.” DWORKIN, Ronald. Uma questão de princípio, cit, p.12 
ser conservadora, de modo a reverenciar a separação dos Poderes e limitar a atividade jurisdicional à descoberta da vontade do legislador.

Todavia, Dworkin, com propriedade, esclarece que esta empreitada para descobrir a vontade do legislador não traz segurança ao jurisdicionado, ou reverencia a separação dos Poderes, porque não se trata de um processo que traz certeza, ou uma única resposta sobre esta intenção. Isto se pode verificar até mesmo pelos debates legislativos nos anais do Congresso, há muita divergência entre os parlamentares sobre os propósitos da lei, suas intenções.

Nesse sentido, a interpretação mais adequada e justificável, de acordo com a teoria de Dworkin, é aquela que se volta à moralidade política de uma comunidade $^{15}$, não à intenção dos legisladores, ou constituintes, porque até mesmo esta, tendo em vista as divergências dos legisladores e constituintes sobre as proposições políticas que positivaram, será pautada por um critério político:

“(...) a ideia de uma intenção legislativa ou constitucional não tem nenhuma interpretação natural estabelecida que faça o conteúdo da intenção dos constituintes uma simples questão de fato histórico, psicológico ou de outro tipo. A ideia pede uma formulação que juristas e juízes também irão desenvolver de maneira diferente. Qualquer justificativa para uma formulação e, portanto para um entendimento de que os constituintes pretenderam, deve ser encontrada não na história, na semântica ou na análise conceitual, mas na teoria política. Deve ser

15 "Interpretativism, on the other hand, denies that law and morals are wholly independent systems. It argues that law includes not only the specific rules enacted in accordance with the community's accepted practices but also the principles that provide the best moral justification for those enacted rules. The law then also includes rules that follow from those justifying principles, even though those further rules were never enacted. Interpretativism, in other words, treats legal reasoning as I have argued in this book we must treat all interpretative reasoning. It treats the concept of law as an interpretative concept." DWORKIN, Ronald. Justice for hedgehogs, Cambridge, USA: Harvard University Press, 2011, p. 402 
encontrada, por exemplo, num argumento de que uma concepção ajusta-se melhor à teoria de governo representativo. Mas, então, a ideia com que começamos, de que os juízes podem tomar decisões constitucionais apolíticas ao descobrir e impor a intenção dos constituintes, é uma promessa que não pode ser cumprida. Pois os juízes não têm como descobrir essa intenção constitucional em vez de outra, isto é, sem tomar decisões de moralidade política que tinham como objetivo evitar."(g.n. $)^{16}$

Dworkin complementa a importância da moralidade política na atividade interpretativa e, consequentemente, para se chegar ao conceito de Direito, afirmando que:

\begin{abstract}
"A história do último meio século do direito constitucional é, em grande parte, uma investigação exatamente destas questões de moralidade política. Juristas conservadores argumentaram persistentemente (embora de maneira não coerente) a favor de um estilo de interpretar essa cláusula baseado nas intenções do autor e acusaram outros, que usavam um estilo diferente, com resultados mais igualitários, de inventar ao invés de interpretar o direito. Mas tratava-se de vociferação com intuito de ocultar o papel que suas próprias convicções políticas desempenhavam na escolha do estilo interpretativo, e os grandes debates jurídicos quanto à cláusula da igualdade de direitos teriam sido mais esclarecedores se fosse mais amplamente reconhecido que valer-se de uma teoria política não é uma corrupção da interpretação, mas parte do que significa a interpretação." 17
\end{abstract}

Com essas considerações, pode-se dizer que o conceito de Direito enunciado por Dworkin, enquanto interpretação, exige que se recorra à moralidade política de uma comunidade, seja isso realizado de maneira explícita, ou velada, como fazem os originalistas. Há um descompasso, portanto, entre o que a moralidade efetivamente representa nas decisões judiciais e a sua reputação perante os intérpretes do Direito ${ }^{18}$, que em geral refugam a assumir o

DWORKIN, Ronald. Uma questão de princípio, cit, p.77

DWORKIN, Ronald. Uma questão de princípio, cit, pp. 246-247

18 De acordo com ThOMAS D. EISELE, a teoria de Dworkin afirma este descompasso entre a leitura moral que os juízes, efetivamente, fazem e o que eles dizem fazer: "Dworkin claims that while we do 
papel da moralidade no deslinde dos feitos sub judice, quando se trata de um caso difícil que requer a consideração às proposições gerais e abstratas, como os princípios.

Esse caráter interpretativo do Direito, que, na resolução dos casos difíceis, forma-se com a consideração à moralidade política de uma comunidade, pode levar à crítica de que, como se trata de interpretação, que recorre a elementos não expressos no próprio texto da norma, seria possível qualquer afirmação, ou imposição subjetiva da opinião do próprio intérprete sobre o que seria o Direito aplicável ao caso concreto. Ou seja, não haveria qualquer objetividade, ou segurança, na resolução dos casos concretos, mas meros subjetivismos arbitrários.

A respeito desta questão, é importante esclarecer que o conceito de Direito para Dworkin não se pauta por uma interpretação subjetivista, que permite chegar a qualquer resultado no julgamento de um caso difícil submetido à apreciação judicial. Ao contrário, ele afirma que há respostas certas a estes casos, que poderiam ser conhecidas não só pelo juiz, mas também pelas partes. Este tema sobre respostas certas aos casos difíceis será devidamente trabalhado no Capítulo II.3.4, desta dissertação. Por ora, cumpre destacar que o conceito de Direito, enquanto interpretação que considera o aspecto moral, não é incerto, ou flexível, às vontades múltiplas dos julgadores a respeito do que gostariam que o Direito fosse, ao contrário, deve-se observar às dimensões da adequação e justificação do Direito, concebido como um todo íntegro ${ }^{19}$.

in fact engage in a moral reading of Constitution, we still deny that this is what we are doing, and we continue to doubt that such a method of reading is a legitimate approach to our founding document." EISELE, Thomas D. Taking our actual constitution seriously, Michigan Law Review, vol, 95. 1997, p. 1801

19 LAWRENCE B. SOLUM esclarece a importância dessas duas dimensões para resolver os casos difíceis "In Hard Cases, Dworkin offered a view of interpretation that seemed to distinguish between easy cases, where the legal sources did the work, and hard cases, in which judges were required to move beyond the rules that were explicit in legal texts (such as constitutional provision, statutes, and cases) 
O Direito, enquanto integridade ${ }^{20}$, para Dworkin é:

\begin{abstract}
“(...) tanto o produto da interpretação abrangente da prática jurídica quanto sua fonte de inspiração. O programa que apresenta aos juízes que decidem casos difíceis é essencialmente, não apenas contingentemente, interpretativo; o direito como integridade pede-lhes que continuem interpretando o mesmo material que ele próprio afirma ter interpretado com sucesso. Oferece-se como continuidade - e como origem - das interpretações mais detalhadas que recomenda." 21
\end{abstract}

Na empreitada de se chegar a esse Direito íntegro, que se desenvolve como um romance em cadeia pelo tempo, Dworkin esclarece a importância da história da comunidade política. A investigação do intérprete sobre a história não deve ser em busca da reconstrução das intenções concretas dos legisladores e constituintes (framers), o que já foi refutado acima, mas deve procurar o intérprete investigar se os framers pretendiam, ou não, positivar uma proposição geral e abstrata:

“(...) a história é um fator pertinente. Mas só o é num sentido particular. Consultamos a história para saber o que eles pretendiam dizer, e não quais outras intenções eles tinham, o que é uma questão muito diferente. Não temos necessidade de

and resort to principles. At this stage, Dworkin explicitly distinguished between the criteria of "fit" and "justification", and seemed to suggest a two-step process. Step one: indentify the set of possible legal rules that fits the existing institutional history (e.g., the texts of authoritative legal materials). If there is only one rule that fits, or if all the rules that fit favor the same resolution of the case, then we need not proceed beyond step one. Step two: select from among those rules on the basis of the principles or values that provide the best justification for that institutional history." SOLUM, Lawrence B. The unity of interpretation, Boston University Law Review, vol. 90, 2010, p. 553

20 STEPHEN GUEST, ao comentar a obra de Dworkin, esclarece que a interpretação adequada do Direito, para o autor, é concebendo-o com um todo íntegro (princípio da integridade), segundo o qual se deve ter como ideia última tratar todas as pessoas com igual consideração: "A proper interpretation of law, according to Dworkin, lies in the idea of integrity. Through this idea we must personify the law treat is as having its own integrity - so that it takes on a moral character, one that consistently treats people as equals." GUEST, Stephen. Ronald Dworkin, 3a edição, Stanford: Stanford University Press, 2012, p. 21

21 DWORKIN, Ronald. O império do direito, cit., p. 273 
saber, por exemplo, o que eles previam ou queriam que acontecesse em decorrência de terem dito o que disseram; nesse sentido, o objetivo deles não faz parte do nosso estudo." 22 (g.n.)

"O direito como integridade, portanto, começa no presente e só se volta para o passado na medida em que seu enfoque contemporâneo assim o determine. Não pretende recuperar, mesmo para o direito atual, os ideais ou objetivos práticos dos políticos que primeiro o criaram. Pretende, sim, justificar o que eles fizeram (às vezes incluindo, como veremos, o que disseram) em uma história geral digna de ser contada aqui, uma história que traz consigo uma afirmação complexa: a de que a prática atual pode ser organizada e justificada por princípios suficientemente atraentes para oferecer um futuro honrado." 23

A respeito desta afirmação sobre a não reconstrução do passado para que o intérprete aplique concretamente a vontade do legislador, mas para que este verifique apenas se ele quis positivar uma proposição geral e abstrata, pode-se mencionar o caso Brown vs. Board of Education, citado por Dworkin em sua obra, no qual a Suprema Corte norte-americana decidiu sobre a segregação racial nas escolas públicas dos Estados Unidos, e sua eventual compatibilidade com a Décima Quarta Emenda da Constituição norteamericana, que consagra a igual proteção da lei ${ }^{24}$.

Os juízes da Suprema Corte norte-americana mesmo cientes que na época que tal emenda foi positivada, ainda perdurava a escravidão nos Estados Unidos, ou seja, que essa igualdade na intenção concreta dos constituintes não se dirigia a todos, decidiram que a segregação racial violava o

22 DWORKIN, Ronald. O direito da liberdade: A leitura moral da Constituição norte-americana, cit., p. 15

23 DWORKIN, Ronald. $O$ império do direito, cit., p. 274

24 Com relação à crítica de Dworkin ao originalismo e a ilustração com o caso Brown vs. Board of Education, MICHAEL DORF destaca a sua relevância: "Dworkin offers Brown vs. Board of Education as the starting point for his critique of originalism. Because of the central place Brown occupies in modern constitutional law, Dworkin contends that "no theory seems acceptable that condemns that decision as a mistake" (p. 268). Yet the proponents of the Fourteenth Amendment did not intend it to outlaw segregated education." DORF, Michael C. Truth, Justice, and the American Constitution, Columbia Law Review, vol. 97:133, 1997, p. 139 
princípio da igualdade previsto na Décima Quarta Emenda. Para Dworkin, o acerto desta decisão, hoje, pode parecer inquestionável, mas à época foi bastante controvertida a sua aceitação, em especial, tendo em vista a intenção dos constituintes quando formularam tal emenda.

Esta decisão é um exemplo clássico de Dworkin para demonstrar que os juízes devem estar atentos, quando se trata da interpretação de princípios, não à intenção concreta dos legisladores/constituintes sobre o que queriam que estes princípios fizessem, mas se de fato estes queriam positivar uma proposição geral e abstrata. Nesse sentido, com o auxílio deste caso prático, foi esclarecido o papel particular da história na concepção do Direito como integridade para Dworkin.

Superada esta etapa, retomam-se as dimensões da adequação e justificação do Direito, concebido como um todo íntegro, decorrente de um processo interpretativo, necessárias ao esclarecimento de que não coaduna com esta visão de Direito de Dworkin a interpretação por um viés puramente subjetivo, impondo o intérprete qualquer convicção sobre o que o Direito seria.

A dimensão da adequação, proposta por Dworkin, determina que a interpretação deve fazer sentido com a história já escrita ${ }^{25}$, ou seja, com o texto

25 Há críticas de comentadores dirigidas a Dworkin sobre esta questão da limitação da história, segundo a qual há dois "Dworkins", um que prezaria pela adequação histórica e outro que busca a resposta certa e que, com esse objetivo em mente, passaria por cima da história, se fosse necessário, para encontrar a melhor resposta. A esse respeito, menciona-se MiCHAEL W. MCCONNELL o qual argumenta que: "Running through Dworkin's account is a profound ambivalence toward arguments based on history (text, history, practice, and precedent). It is not too much to say that there are two Dworkins, with two quite different versions of "The Moral Reading." I will call these "the Dworkin of Fit" and "the Dworkin of Right Answers." According to the Dworkin of Fit, judges are, and should be, seriously constrained by what has come before by text, history, tradition, and precedentand should exercise their moral-philosophical faculties only within the limits set by history. The Dworkin of Fit recognizes that the constraints of history are an indispensable part of the "principle" that governs judicial decision making. The Dworkin of Right Answers, by contrast, distinguishes sharply between "the party of history" (bad) and "the party of principle"(good). He insists that text, history, and unwelcome precedent must be interpreted at a sufficiently abstract level that they do not 
que lhe foi entregue, deve haver uma coerência na continuidade da história. Então, por mais que pareça ao intérprete melhor, mais interessante, que a história tome certo rumo sem nexo algum com o passado, ele não pode impor esta visão, pois feriria a dimensão da adequação, que exige um mínimo de coerência no prosseguimento do romance em cadeia. Dworkin esclarece que esta coerência não precisa ser absoluta com todo o conteúdo do texto, porque muitas vezes os próprios autores anteriores escrevem de forma incoerente alguns capítulos desta história, todavia, deve fazer sentido com o texto analisado como um todo; deve guardar esta relação de adequação estrutural com a maior parte do texto:

"A primeira é a que até aqui chamamos de dimensão da adequação. Ele não pode adotar nenhuma interpretação, por mais complexa que seja, se acredita que nenhum autor que se põe a escrever um romance com as diferente leituras de personagem, trama, tema e objetivo que essa interpretação descreve, poderia ter escrito, de maneira substancial, o texto que lhe foi entregue. Isso não significa que sua interpretação deva se ajustar a cada segmento do texto. Este não será desqualificado simplesmente porque ele afirma que algumas linhas ou alguns tropos são acidentais, ou mesmo que elementos da trama são erros, pois atuam contra ambições literárias que são afirmadas pela interpretação. Ainda assim, a interpretação que adotar deve fluir ao longo de todo o texto; deve possuir um poder explicativo geral, e será mal sucedida se deixar sem explicação algum importante aspecto estrutural do texto $(\ldots) ., 26$

interfer with the judge's ability to make the Constitution "the best it can be."The "best reading" is the reading that, in the judge's own opinion, will produce the best answers, defined philosophically and not historically." (MCCONNELL, Michael W. The Importance of humildity in judicial review: a comment on Ronald Dworkin's Moral Reading of the Constitution, Fordham Law Review, vol. 65, 1997, p. 1270) Esta crítica parece se equivocar. Explica-se. Dworkin, realmente, admite que a história é um importante fator de limitação na construção de sua decisão judicial, todavia, em momento algum afirma que há um dever de coerência com todos os elementos dela. Se um deles se apresentar anacrônico, incoerente, poderá ser afastado, porque a aplicação dele implicaria em uma resposta que menos se justificaria diante de toda prática jurídica. Essa questão de afastamento de uma decisão política passada é melhor esclarecida no Capítulo II.3.1., referente às etapas da interpretação e o método de Hércules.

26 DWORKIN, Ronald. O império do direito, cit., p. 277 
A dimensão da adequação permite ao intérprete chegar a uma série de possíveis continuidades ao texto, exclui algumas possibilidades, mas ainda permanecem várias a sua escolha. Desse modo, para que se escolha a melhor continuidade ao texto, deve-se recorrer a uma outra dimensão importante, qual seja, a justificação.

A dimensão da justificação, proposta por Dworkin, exige que a escolha do intérprete seja a melhor ${ }^{27}$ em consideração ao texto em desenvolvimento, isto é, que coadune com a moralidade política daquela comunidade, que analise os compromissos passados e presentes e preveja os anseios futuros dos cidadãos para com seu próximo e com o seu país, na escolha de uma das possíveis interpretações. Dworkin aproxima essa dimensão da justificação com os juízos estéticos:

\begin{abstract}
“(...) entram em jogo os juízos estéticos mais profundos sobre a importância, o discernimento, o realismo ou a beleza das diferentes ideias que se poderia esperar que o romance expressasse. Mas as considerações formais e estruturais que dominam a primeira dimensão também estão presentes na segunda, pois mesmo quando nenhuma das duas interpretações é desqualificada por explicar muito pouco, pode-se demonstrar o texto sob uma melhor luz, pois se ajusta a uma maior parte do texto ou permite uma integração mais interessante de estilo e conteúdo." 28
\end{abstract}

Para ilustrar um intérprete que respeita o Direito como integridade e aplica com perfeição as dimensões de adequação e justificação, Dworkin cria

\footnotetext{
27 A esse respeito, menciona-se STEPHEN GUEST: "His perspective on law is that of justification. We must interpret the law to make the best 'moral' sense of it. In other words, we must always assume when we try to work out what the law requires or permits that it makes moral sense. What is the point, he asks, of justifying action in the name of law unless that action has also a moral justification? This is the major concern of Dworkin's moral and political theory and rests upon what we might call his foundational principle: that people should be treated with equal concern and respect. When we are making sense of law, we must assume that its best sense expresses an equal concern for people." GUEST, Stephen. Ronald Dworkin, cit., p. 19

28 DWORKIN, Ronald. O império do direito, cit., p. 278
} 
o juiz Hércules, que teria "capacidade e paciência sobre-humanas" 29 . O método de proceder do juiz Hércules e as etapas da interpretação serão abordados em Capítulo próprio (Capítulo II.3.1), desta dissertação, e complementará a empreitada, aqui iniciada, no intuito de esclarecer o conceito de Direito elaborado por Dworkin em sua obra.

Em conclusão a este Capítulo introdutório a respeito do conceito de Direito elaborado por Dworkin, por ora, já se pode afirmar que: o Direito é um conceito interpretativo, que se constrói como um todo íntegro, observadas as dimensões de adequação e justificação no processo interpretativo; que exige a consulta aos elementos históricos do processo legislativo apenas para saber o que seus autores (framers) efetivamente disseram, desvencilhando-se de suas intenções no caso concreto. Desse modo, se a história permite concluir que os autores prescreveram um princípio constitucional geral, não se deve limitar a interpretação deste princípio ao modo como os autores o aplicariam no caso concreto.

O conceito de Direito, portanto, apresenta grande dinamicidade, na medida em que não se trata de uma mera consideração acerca de um repertório jurídico de leis, costumes, jurisprudência, doutrina etc., ou uma simples reconstrução das intenções dos legisladores; exige do intérprete um trabalho muito mais complexo que envolve a consideração à moralidade política de uma comunidade em constante desenvolvimento e evolução. Somente assim será possível manter a integridade na redação do romance em cadeia:

“(..) o direito não é esgotado por nenhum catálogo de regras ou
princípios, cada qual com seu próprio domínio sobre uma
diferente esfera de comportamentos. Tampouco por alguma
lista de autoridades com seus poderes sobre parte de nossas

29 DWORKIN, Ronald. O império do direito, cit., p. 287 
vidas. O império do direito é definido pela atitude, não pelo território, o poder ou o processo. (...) É uma atitude interpretativa e auto-reflexiva, dirigida à política no mais amplo sentido. É uma atitude contestadora que torna o cidadão responsável por imaginar quais são os compromissos públicos de sua sociedade com os princípios, e o que tais compromissos exigem em cada nova circunstância. (...) A atitude do direito é construtiva: sua finalidade, no espírito interpretativo, é colocar o princípio acima da prática para mostrar o melhor caminho para um futuro melhor, mantendo a boa-fé com relação ao passado. É, por último, uma atitude fraterna, uma expressão de como somos unidos pela comunidade apesar de divididos por nossos projetos, interesses e convicções. Isto é, de qualquer forma, o que o direito representa para nós: para as pessoas que queremos ser e para a comunidade que pretendemos ter." 30

Para Dworkin, portanto, o conceito de Direito como integridade advém de uma atitude interpretativa e auto-reflexiva, que assume um papel transformador na sociedade complexa em que se vive, unindo as dimensões do passado, presente e futuro de um romance em constante desenvolvimento, que passa de mãos em mãos, na construção de uma comunidade política melhor aos anseios dos cidadãos que a compõem.

\section{II.1.1. DIREITO COMO INTEGRIDADE VS. CONVEncionalismo e Pragmatismo Jurídico}

Realizada a introdução do conceito de Direito, enquanto integridade, é importante dar mais luz a ele confrontando-o com duas correntes importantes, quais sejam, o convencionalismo e o pragmatismo jurídico. Estas duas correntes foram eleitas pelo próprio Dworkin, em seu livro O Império do Direito, para confrontar com o conceito de Direito como integridade por ele elaborado, por serem elas representativas quanto às posturas mais frequentes dos intérpretes perante o Direito na resolução dos casos difíceis.

30 DWORKIN, Ronald. O império do direito, cit., p. 492 
O convencionalismo pauta-se por um conceito de Direito, que seria aquilo que foi posto pelas decisões políticas passadas, reduzindo o papel dos juízes, nas decisões judiciais, a uma mera reprodução daquilo que foi posto:

"O direito é o direito. Não é o que os juízes pensam ser, mas aquilo que realmente é. Sua tarefa é aplicá-lo, não modificá-lo para adequá-lo à sua própria ética ou política. (...) a força coletiva só deve ser usada contra o indivíduo quando alguma decisão política do passado assim o autorizou explicitamente, de tal modo que advogados e juízes competentes estarão todos de acordo sobre qual foi a decisão, não importa quais sejam suas divergências em moral e política." 31

A corrente convencionalista, como o próprio nome sugere, insiste na aplicação da convenção, nesse sentido, saber o que é o Direito é uma atividade que se volta para o passado, o toma como algo estático, definido nos exatos termos estabelecidos na convenção.

Todavia, quando os adeptos do convencionalismo se deparam com um caso difícil - em que não há convenção, ou seja, quando a decisão política sobre um determinado assunto não foi tomada por quem competia juridicamente -, eles admitem que os juízes exercitem o poder discricionário e criem um direito novo. Ou seja, nos casos em que não há convenção, não há Direito, e, por conseguinte, para solucionar o caso sub judice, o juiz deve criar um Direito novo. $^{32}$

31 DWORKIN, Ronald. O império do direito, cit., p.141

32 "En principio los jueces están determinados por las decisiones del pasado siempre y cuando estas decisiones se hayan producido. Si no hay decisión previa entonces el juez no se ve limitado y decide discrecionalmente. Dworkin llama convencionalismo a esta posición. El derecho se encuentra en las convenciones del pasado. El pasado determina el presente. El valor subyacente está claro. La fidelidad a la ley supone la garantía de la seguridade jurídica." CALSAMIGLIA, Albert. El concepto de integridad en Dworkin, Doxa: Cuadernos de Filosofía del Derecho, núm. 12, 1992, p. 161 
O processo de criação desse Direito novo, como esclarece Dworkin ao discorrer sobre o convencionalismo, recorre a padrões extrajurídicos:

\begin{abstract}
"Declara que não existe direito - nenhum direito decorrente de decisões tomadas no passado - a não ser aquele extraído de tais decisões por meio de técnicas que são, elas próprias, questões de convenção, e que, portanto, em alguns casos não existe direito algum. (...) Não se segue daí que os juízes confrontados com tal problema devam cruzar os braços e mandar as partes para casa sem tomar decisão alguma. Esse é o tipo de caso em que os juízes devem exercitar o poder discricionário há pouco descrito, isto é, usar padrões extrajurídicos para fazer o que o convencionalismo considera ser novo direito. Depois, em casos futuros, a convenção do precedente transformará esse novo direito em direito antigo." ${ }^{, 3}$
\end{abstract}

Desse modo, ao contrário da concepção do Direito como integridade, entende-se que os casos difíceis são decididos com base no poder discricionário do juiz, visto que não há direito anterior a pautar a decisão, esta seria formada por elementos extrajurídicos, criando-se, a partir de então, um Direito novo.

Pela teoria convencionalista, conforme enunciada por Dworkin, apenas nestes casos difíceis, o juiz deve deixar a convenção de lado, nos demais sempre deve seguir o direito posto, mesmo se entender que este é injusto ao analisar o caso concreto. Desse modo, há uma forte previsibilidade para parte e operadores do Direito quanto aos comportamentos legais e ilegais vigentes ${ }^{34}$, que lhe permitirão ter o ganho, ou perda, de uma determinada causa. Essa teoria, como esclarece Dworkin, pode ser bastante sedutora para aqueles que tendem a

33 DWORKIN, Ronald. O império do direito, cit., pp. 144-145

34 "O convencionalismo não nega que muitos advogados têm posições antagônicas sobre a melhor interpretação da prática que compartilham. Afirma que esses advogados estão errados, que lhes falta perspicácia e percepção, que interpretam mal seu próprio comportamento." DWORKIN, Ronald. $O$ império do direito, cit., p. 144 
justificar a possibilidade de coerção do Estado, apenas com base nas decisões políticas passadas (concepção de Estado de Direito centrada nas regras, conforme Capítulo infra, III.1, desta dissertação):

\begin{abstract}
"As decisões políticas do passado justificam a coerção porque, e portanto apenas quando, fazem uma advertência justa ao subordinarem as ocasiões de coerção a fatos simples e acessíveis a todos, e não a apreciações recentes da moralidade política, que juízes diferentes poderiam fazer de modo diverso. (...) Insiste em que, uma vez tomada uma decisão clara por um organismo autorizado por convenção, e que o conteúdo de tal decisão foi estabelecido em conformidade com as convenções sobre a melhor maneira de compreender tais decisões, os juízes devem respeitar essa decisão, mesmo achando que uma decisão diferente teria sido mais justa ou sábia ${ }^{~} 35$
\end{abstract}

O convencionalismo, todavia, não responde ao problema da coerção quando se lida com casos difíceis, na medida em que admitem a criação de um Direito novo, que será aplicado retroativamente às partes para resolver um caso difícil em questão. Retira-lhe, portanto, a previsibilidade, a segurança jurídica, para orientar seus comportamentos em sociedade, ou seja, retira a característica mais enaltecida pelos convencionalistas - que é a certeza trazida pela convenção.

Nesse sentido, para que a compreensão do tema atinja a envergadura necessária, é importante dar um passo atrás e esclarecer o que é um caso difícil para um convencionalista. A afirmação de que um caso difícil é aquele em que não há convenção é correta, mas não alinhava alguns pontos importantes sobre a extensão daquilo que se entende por convenção. A respeito dessa questão, Dworkin distingue duas correntes de convencionalistas: o convencionalismo estrito e o convencionalismo moderado.

35 DWORKIN, Ronald. O império do direito, cit., pp. 145-146 
Os convencionalistas estritos defendem que a lei é apenas a extensão explícita da convenção, que corresponderia à parte sobre a qual todos acordão sobre o seu conteúdo (por exemplo, todo réu tem direito de produzir provas); mas não se inclui na lei a sua extensão implícita, na qual reside a divergência dos intérpretes (por exemplo, quais são os meios de provas aceitos num dado caso concreto, caso a lei não disponha a respeito). Então, a lei para os convencionalistas estritos seria aquilo que está na extensão explícita da convenção, enquanto, para os convencionalistas moderados, também, incluiria a extensão implícita da convenção:

"A primeira, que poderíamos chamar de convencionalismo "estrito" restringe a lei de uma comunidade à extensão explícita de suas convenções jurídicas, como a legislação e o precedente. A segunda, que vamos aqui chamar de convencionalismo "moderado", insiste em que o direito de uma comunidade inclui tudo que estiver dentro da extensão implícita dessas convenções. (...) O convencionalismo estrito seria para nós uma concepção muito restritiva do direito, pois as extensões explícitas de nossas convenções putativas da legislação e do precedente contêm muito poucos elementos de grande importância práticas nos litígios reais. Se tentássemos descrever uma teoria da legislação que fosse incontestável o suficiente para obter consenso universal entre nossos juristas e juízes, ficaríamos limitados a algo assim: se os termos de uma lei admitem um único significado, não importa o contexto em que sejam formulados, e se não tivermos razão para duvidar de que é esse o significado entendido por todos os legisladores que votaram a favor ou contra essa lei, ou que se abstiveram, e a lei assim entendida não obtém nenhum resultado não pretendido por todos os que votaram a favor dela, e seria assim entendida por todos os membros do público ao qual se dirige, e se nenhuma pessoa sensata nela visse uma violação de qualquer imposição substantiva ou processual da Constituição, nem uma ofensa a nenhum ponto de vista sobre a equidade ou a eficiência da legislação, então as proposições contidas nessa lei, assim compreendidas, fazem parte do direito da comunidade. ${ }^{36}$

36 DWORKIN, Ronald. O império do direito, cit., pp. 152-153 
Como se pôde constatar do excerto selecionado acima, há uma séria limitação do convencionalismo estrito, na medida em que os casos concretos, em geral, demandam análises mais profundas da lei que extrapolam aquilo que está explícito nela, havendo em alguma medida divergência entre os intérpretes sobre a medida exata da aplicação dos comandos legais ao caso concreto. Por essa razão, o convencionalismo moderado tem atraído mais adeptos do que o estrito, na medida em que permite que os juízes e intérpretes em geral possam modelar de maneira mais profícua a lei ao caso concreto, recorrendo à sua extensão implícita. ${ }^{37}$

Partindo dessas considerações, verifica-se que o ponto de convergência dos convencionalistas é a necessidade do juiz e intérpretes, em geral, pautarem-se pela convenção; e a divergência residiria na extensão daquilo que se entende por convenção (extensão explícita e implícita). Nesse esteio, Dworkin esclarece que para os convencionalistas moderados, ou seja, para aqueles que admitem a extensão implícita da convenção, não há lacunas no Direito, na medida em que aplicam aos casos concretos aspectos não expressos na convenção, como se dela realmente fizessem parte, não havendo, portanto, um caso difícil sob essa perspectiva. ${ }^{38}$

\footnotetext{
37 “A parte positiva do convencionalismo moderado orienta os juízes a decidirem segundo sua própria interpretação das exigências concretas da legislação e do precedente, ainda que isso possa ser controverso, e esse conselho não é irrelevante nos casos difíceis.”DWORKIN, Ronald. O império do direito, cit., p. 154

38 "O convencionalismo estrito deve declarar uma 'lacuna' no direito, que requer o exercício de um poder discricionário extralegal por parte do juiz para criar um novo direito sempre que uma lei for vaga, ambígua ou problemática de alguma maneira, e não houver outra convenção sobre o modo de interpretá-la. Ou quando a intenção de uma cadeia de precedentes for incerta, e os juristas não chegarem a um consenso sobre sua força. Contudo, o convencionalista moderado não precisa admitir 'nenhuma' lacuna em tais casos. Pode afirmar, de modo plausível, que existe uma maneira correta, ainda que polêmica, de interpretar as convenções abstratas da legislação e do precedente, de tal modo que elas decidam qualquer caso que possa surgir. (...) $\mathrm{Na}$ verdade um convencionalista moderado poderia negar a existência de lacunas mesmo que os advogados divergissem sobre essas convenções abstratas, mesmo que muitos juristas se recusassem a admitir que as leis fazem direito, ou que os precedentes exercem alguma influência sobre decisões posteriores.” DWORKIN, Ronald. O império do direito, cit., p. 155
} 
Dworkin, ao contrapor a sua concepção de Direito como integridade ao convencionalismo, refere-se ao convencionalismo estrito, ou seja, aquele que admite lacunas no Direito e, por conseguinte, a existência de casos difíceis. Enquanto, em outro sentido, os convencionalistas moderados acreditam na completude do ordenamento e na possibilidade de resolver todos os casos concretos postos sob análise com base na convenção, recorrendo à sua extensão implícita.

Por essa razão, feitos estes esclarecimentos, é possível afirmar que a segurança jurídica, prezada pelos convencionalistas, na resolução dos casos difíceis, não encontra guarida nem no convencionalismo moderado (na medida em que este admite a extensão implícita da convenção para resolver casos complexos); nem no convencionalismo estrito (na medida em que este admite fazer uso do poder discricionário, recorrendo a elementos extrajurídicos, para resolver os casos não previstos na convenção).

Nesse sentido, é possível afirmar que ao convencionalismo moderado falta franqueza de admitir que não estão na convenção elementos que afirmam estar nela para resolver uma questão complexa; e ao convencionalismo estrito falta uma visão realística do sistema jurídico para perceber que são poucos os casos em que é possível obter uma resposta óbvia a partir da análise daquilo que está explícito na convenção.

O convencionalismo, portanto, na visão de Dworkin, fracassa em seu objetivo de segurança jurídica com o respeito às decisões políticas passadas, porque estas não serão suficientes na maior parte dos casos concretos sub judice:

"Do mesmo modo que o aspecto positivo do convencionalismo 
perde sua importância prática no tribunal, pois são muito poucas as ocasiões em que os juízes podem apoiar-se no direito do modo como o convencionalismo o interpreta, essa defesa específica do aspecto negativo torna-se mais fraca, pois as exceções invariavelmente se sobrepõe à regra. (...) $\mathrm{O}$ convencionalismo estrito fracassa como interpretação de nossa prática jurídica mesmo quando - e sobretudo quando enfatizamos seu aspecto negativo. E fracassa pela seguinte razão paradoxal: nossos juízes, na verdade, dedicam mais atenção às chamadas fontes convencionais do direito, como as leis e os precedentes, do que lhes permite o convencionalismo. Um juiz consciente de seu convencionalismo estrito perderia o interesse pela legislação e pelo precedente exatamente quando ficasse claro que a extensão explícita dessas supostas convenções tivesse chegado ao fim. Ele então entenderia que não existe direito, e deixaria de preocupar-se com a coerência com o passado; passaria a elaborar um novo direito, indagando qual lei estabeleceria a legislatura em vigor, qual é a vontade popular ou o que seria melhor para os interesses da comunidade no futuro." 39

Outro elemento relevante, que auxilia na elucidação dessa falsa segurança trazida pelos convencionalistas, é a forma como eles compreendem o dever de coerência com o passado. Nos casos difíceis, para o convencionalista ${ }^{40}$, o dever de coerência é apenas devido em seu sentido "estratégico", e não de "princípios", como exige o Direito como integridade concebido por Dworkin. O convencionalista não tem o dever de buscar princípios que subjazem à resolução da questão difícil, e que permitem, dentro desta perspectiva, unidade no ordenamento, visto como um todo interligado, cuja coerência está nos princípios que o norteiam. Pela coerência estratégica exige-se tão somente a verificação se aquela decisão, que teve de recorrer a padrões extrajurídicos, não apresenta uma contradição à convenção, não sendo necessário e nem desejável, por esta perspectiva, que se recorra a algo abstrato e mais amplo que a literalidade da lei. Metaforicamente, poder-se-ia dizer que a coerência estratégica apenas exige que

39 DWORKIN, Ronald. O império do direito, cit., pp. 158-159

40 Dworkin, apesar de ter feito a distinção entre os convencionalistas estritos e moderados, esclarece que quando se refere aos "convencionalistas", sem os adjetivos estrito ou moderado, refere-se aos convencionalistas estritos. 
se olhe para o lado (visão horizontal focada nas regras) e não para cima (visão vertical voltada para os princípios):

\begin{abstract}
"Mas o convencionalismo difere do direito como integridade exatamente porque o primeiro rejeita a coerência de princípio como uma fonte de direitos. O segundo a aceita: o direito como integridade supõe que as pessoas têm direitos - direitos que decorrem de decisões anteriores de instituições políticas, e que, portanto, autorizam a coerção - que extrapolam a extensão explícita das práticas políticas concebidas como convenções. $\mathrm{O}$ direito como completude supõe que as pessoas têm direito a uma extensão coerente, e fundada em princípios, das decisões políticas do passado, mesmo quando os juízes divergem profundamente sobre seu significado. Isso é negado pelo convencionalismo: um juiz convencionalista não tem razões para reconhecer a coerência de princípio como uma virtude judicial, ou para examinar minuciosamente leis ambíguas ou precedentes inexatos para tentar alcançá-la."41
\end{abstract}

A convenção, enquanto regra, perde seu significado em uma visão temporal perspectiva, seja pela evolução dos tempos que modifica a maneira como se interpreta o significado das normas insculpidas na convenção, seja pela alteração da própria convenção. O que permanece, em uma dada comunidade política, não são as regras, constantemente em mutação, mas os princípios, que são a base fundante desta comunidade.

Sob este aspecto, pode-se dizer que o Direito, como integridade, exige a coerência de princípios e fornece uma solução mais segura e estável à resolução dos casos difíceis do que o convencionalismo, que aceita recorrer a padrões extrajurídicos para resolvê-las, tendo como parâmetro as regras, não os princípios.

Considerando a necessidade do convencionalista de recorrer a

${ }^{41}$ DWORKIN, Ronald. O império do direito, cit., p. 164 
padrões extrajurídicos, as partes não têm segurança jurídica, pois não conseguem saber com antecedência o seu direito, e planejar suas ações de acordo com ele.

A questão que dá o tom de todo o debate, empreendido neste Capítulo, é a medida exata do equilíbrio entre estabilidade/previsibilidade e flexibilidade. Cada uma dessas visões de Direito tende a ressaltar uma dessas qualidades. Com fim de instruir o debate do Direito como integridade, confrontado com outras importantes teorias sobre a concepção de Direito, introduz-se a última teoria que se irá tratar neste Capítulo, o pragmatismo.

O pragmatismo diferencia-se do convencionalismo, especialmente, no que diz respeito à valorização da flexibilidade à previsibilidade ${ }^{42}$, uma vez que o pragmático procura voltar seu olhar para o futuro, na procura de decisões que atendam melhor às expectativas prospectivas de uma dada comunidade política. Nesse sentido, a convenção (regras e precedentes) assume um papel menor e pode ser desconsiderada nas decisões judiciais, desde que outra solução indique ser o melhor caminho a se seguir a partir dali.

Dworkin esclarece que o pragmático:

“(...) adota uma atitude cética com relação ao pressuposto que acreditamos estar personificado no conceito de direito: nega que as decisões políticas do passado, por si sós, ofereçam qualquer justificativa para o uso ou não do poder coercitivo do Estado. Ele encontra a justificativa necessária à coerção na justiça, na eficiência ou em alguma outra virtude contemporânea da própria decisão coercitiva, como e quando ela é tomada por juízes, e acrescenta que a coerência com qualquer decisão legislativa ou judicial anterior não contribui, em princípio, para a justiça ou a virtude de qualquer decisão

42 DWORKIN, Ronald. O império do direito, cit., p. 182 
atual. Se os juízes se deixarem guiar por esse conselho, acredita ele, então, a menos que cometam grandes erros, a coerção que impõem tornará o futuro da comunidade mais promissor, liberado da mão morta do passado e do fetiche da coerência pela coerência." 43

Os pragmáticos têm uma visão cética do direito, segundo a qual as pessoas não têm previamente direito a ganhar uma causa com base em decisões políticas passadas, tudo é incerto, e a incerteza permite aos juízes a quebra de paradigmas, que considerarem não mais atender aos interesses daquela comunidade, seja por uma questão de justiça, eficiência etc. Pode-se constatar, por esta visão, que o pragmático preza pela flexibilidade e não pela estabilidade/previsibilidade. O foco está no futuro e as decisões políticas passadas são tomadas apenas como referências positivas, ou negativas, para a tomada de decisão no presente. Não vinculam, servem apenas de referência, com o propósito de construção de uma prática jurídica melhor aos interesses da comunidade.

Na prática, porém, Dworkin esclarece que o pragmatismo acaba não sendo tão radical quanto aparenta ser na teoria, uma vez que os pragmáticos compreendem que a desconsideração de algumas decisões políticas passadas pode gerar instabilidade na comunidade política, pois as pessoas não saberiam os impostos que têm de pagar; as ações que não podem cometer na esfera criminal etc. Esta instabilidade da comunidade política não é desejada pelos pragmáticos.

Desse modo, em alguns casos, entendem que devem decidir com base nas decisões políticas passadas, porque os efeitos destas serão positivos no futuro. Explica-se. Estas decisões atenderão a algumas expectativas relevantes

43 DWORKIN, Ronald. O império do direito, cit., p. 185 
ao funcionamento da sociedade, em especial, nas áreas de direito público, como direito penal e tributário. As pessoas físicas e jurídicas necessitam ter estabilidade/previsibilidade em algumas questões para que não se instaure o caos social. Basta imaginar alguém ser preso por um ato que o juiz, sem base legal, decidiu ser crime naquele momento. Ou, então, que o juiz decidiu ser devida uma quantia em tributos, que não estão previstos em lugar algum, confiscando bens e punindo os "infratores" sem qualquer base legal. Estes são exemplos que retratam situações inaceitáveis, que levariam a uma grave instabilidade institucional e social, quiçá a uma guerra civil, e o pragmático não deseja o caos futuro. Por essa razão, apenas nos casos de direito privado, que se acaba revelando a faceta mais inovadora do pragmático, com as quebras de paradigmas.

Nestes casos, as pessoas nas suas relações privadas em geral, sabendo que os juízes são pragmáticos e, portanto, decidirão os litígios colocados à sua apreciação com base naquilo que acreditam ser o melhor para a comunidade no futuro, mesmo sem qualquer base legal, tenderão a agir da melhor forma possível para evitar dissabores judiciais. A incerteza dos direitos, sob este aspecto, é uma ferramenta no controle social que leva as pessoas não a procurar as brechas da lei (como um convencionalista poderia fazer), com intuito de adequar a lei ao seu interesse particular a despeito da sociedade. Ao revés, a incerteza leva as pessoas a adequarem o seu comportamento dentro daquilo que consideram o melhor para a comunidade, pois não sabem de antemão o que o juiz considerará enquanto tal, não há espaço para buscar brechas, mas esforço na busca dentre as diversas interpretações daquilo que é o melhor para a comunidade, pois esta conduta é a que melhor lhe assegura quanto aos riscos de sucumbência em eventual litígio judicial.

A esse respeito, Dworkin esclarece que: 
"O pragmatismo não exclui nenhuma teoria sobre o que torna uma comunidade melhor. Mas também não leva a sério as pretensões juridicamente tutelada. Rejeita aquilo que outras concepções do direito aceitam: que as pessoas podem claramente ter direitos, que prevalecem sobre aquilo que, de outra forma, asseguraria o melhor futuro à sociedade. Segundo o pragmatismo, aquilo que chamamos de direitos atribuídos a uma pessoa são apenas auxiliares do melhor futuro: são instrumentos que construímos para esse fim, e não possuem força ou fundamento independentes." 44

É evidente que cada juiz pode entender de maneira diversa e, em alguns casos, até mesmo oposta, aquilo que julga melhor representar os anseios futuros da comunidade, o que prejudica o planejamento das ações das pessoas, que por mais que queiram fazer tudo certo, podem sofrer com uma sucumbência judicial, absolutamente, inesperada.

Nessa toada, pode-se dar um passo além e afirmar que a ruptura com o passado, na forma de descompromisso com as decisões políticas pretéritas, por mais que esteja repleta de boas intenções (o que nem sempre é verdade), revela a falta de coerência política e jurídica do pragmático, na medida em que este pode resolver traçar um caminho absolutamente distinto do já traçado se entender que esta é a melhor maneira de aprimorar a comunidade no futuro. Falta-lhe integridade, visão do conjunto, e continuidade do romance em cadeia. Na visão de Direito como integridade de Dworkin, a história de uma comunidade política precisa continuar com coerência de princípios e não ser uma colcha de retalhos sem sentido, para tanto é necessário respeitar os princípios regentes da integridade: (i) princípio de integridade na legislação; e (ii) princípio de integridade no julgamento.

44 DWORKIN, Ronald. O império do direito, cit., p. 195 
"O primeiro é o princípio da integridade na legislação, que pede aos que criam o direito por legislação que o mantenham coerente quanto aos princípios. O segundo é o princípio de integridade no julgamento: pede aos responsáveis por decidir o que é a lei, que a vejam e façam cumprir como sendo coerente nesse sentido. $\mathrm{O}$ segundo princípio explica que como e por que se deve atribuir ao passado um poder especial próprio no tribunal, contrariando o que diz o pragmatismo, isto é, que não se deve conferir tal poder. Explica por que os juízes devem conceber o corpo do direito que administram como um todo, e não como uma série de decisões distintas que eles são livres para tomar ou emendar uma por uma, com nada além de um interesse estratégico pelo restante." 45

Para que prossiga nesta discussão e seja possível fechá-la, dentro dos propósitos deste Capítulo (distinguir representativas concepções de Direito: convencionalismo; pragmatismo e integridade), é necessário esclarecer um importante ponto recorrente na obra de Dworkin e mencionado em diversos pontos deste Capítulo - a questão da coerência dos princípios da comunidade -, especialmente, no que se refere à tomada de decisão. A esse respeito, mencionou-se que os convencionalistas apenas observam a coerência estratégica nas decisões judiciais e não a coerência de princípios; e que os pragmáticos admitem a sua completa desconsideração, pois voltam seus olhos apenas ao futuro e não ao passado.

Admitir que esta questão é um critério relevante para distinguir as diferentes concepções de Direito, na teoria de Dworkin, não levanta grandes considerações. Todavia, o ponto nodal desta discussão é: se é possível afirmar que uma comunidade tem verdadeiramente estes princípios, e, se for afirmativa esta resposta, se eles advêm do consenso da maioria, ou de alguma outra fonte.

Para tanto, Dworkin recorre à personificação da comunidade

45 DWORKIN, Ronald. O império do direito, cit., p. 203 
política:

\begin{abstract}
"Minha apresentação da integridade política assume a personificação com muito mais seriedade, como se uma comunidade política realmente fosse alguma forma especial de entidade, distinta dos seres reais que são seus cidadãos. Pior ainda, atribui influência e responsabilidade morais a essa entidade distinta. Pois, quando digo que uma comunidade é fiel aos seus próprios princípios, não me refiro a sua moral convencional ou popular, às crenças e convicções da maioria dos cidadãos. Quero dizer que a comunidade tem seus próprios princípios que pode honrar ou desonrar, que ela pode agir de boa ou má-fé, com integridade ou de maneira hipócrita, assim como fazem as pessoas." $" 46$
\end{abstract}

Como se pode extrair do excerto selecionado, os princípios de uma comunidade política não decorrem do consenso da maioria momentânea ${ }^{47}$, ao contrário, são decorrentes da comunidade personificada que supera a barreira temporal e é representada por uma visão conjunta do passado, presente e futuro, na constituição da moralidade política da comunidade. O convencionalismo só olha para trás (passado); o pragmático só olha para frente (futuro); e o Direito como integridade olha para o todo (passado, presente e futuro). Os princípios a que se deve obediência e que devem nortear todas as decisões políticas e jurídicas, na teoria de Dworkin, são os princípios da comunidade personificada.

A coerência de princípios de uma comunidade personificada não permite soluções conciliatórias ${ }^{48}$, que, para Dworkin, são aquelas oriundas de uma tentativa do legislador, ou dos juízes, de agradar a "gregos" e "troianos", seja em um mesmo recorte temporal, ou em momentos diferentes. Por exemplo, uma mesma Corte, diante de questões semelhantes, que envolvam os mesmos

${ }^{46}$ DWORKIN, Ronald. O império do direito, cit., p. 204

47 A relação entre Democracia e vontade da maioria será tratada com profundidade no Capítulo III.3. "Violação da Democracia" desta dissertação.

48 “(...) se as soluções conciliatórias têm um defeito, este deve estar na característica que as distingue de outras, no fato de tratarem as pessoas diferentemente quando nenhum princípio pode justificar a distinção." DWORKIN, Ronald. O império do direito, cit., p. 219 
princípios, decide de maneira contraditória sem que as peculiaridades do caso concreto justifiquem qualquer tratamento diferenciado. Este tipo de contradição revela arbitrariedade, ofende a segurança jurídica, além de violar a coerência de princípios, exigida pelo Direito como integridade.

A moralidade política de uma comunidade ${ }^{49}$, chave para construção do Direito como integridade, é algo muito mais estável e que oferece mais segurança jurídica, especialmente na resolução dos casos difíceis, do que a teoria convencionalista, que recorre a elementos extrajurídicos, ou a pragmática, que desconsidera as decisões políticas passadas. O compromisso do Direito como integridade aos princípios da comunidade, pilares fundantes de uma verdadeira comunidade política, além da estabilidade e coerência intertemporal, oferece outros benefícios se comparado com as outras concepções de Direito, conforme esclarece Dworkin:

\begin{abstract}
"A integridade protege contra a parcialidade, a fraude e outras formas de corrupção oficial, por exemplo. (...) A integridade também contribui para a eficiência do direito no sentido que já assinalamos aqui. Se as pessoas aceitam que são governadas não apenas por regras explícitas, estabelecidas por decisões políticas tomadas no passado, mas por quaisquer outras regras que decorrem dos princípios que essas decisões pressupõem, então o conjunto de normas públicas reconhecidas pode expandir-se e contrair-se organicamente, à medida que as pessoas se tornem mais sofisticadas em perceber e explorar aquilo que esses princípios exigem sob novas circunstâncias, sem a necessidade de um detalhamento da legislação ou da jurisprudência de cada um dos possíveis pontos de conflito. (...) uma comunidade que aceite a integridade tem um veículo para a transformação orgânica, mesmo que este nem sempre seja totalmente eficaz, que de outra forma sem dúvida não teria." $" 50$
\end{abstract}

\footnotetext{
49 Ressalta-se que a moralidade política de uma comunidade, para Dworkin, é construída ao longo do tempo com as experiências históricas, com respeito ao presente e aos anseios futuros da comunidade, não se tratando de uma moralidade particular de uma determinada época.

50 DWORKIN, Ronald. O império do direito, cit., pp. 228-229
} 
Em suma, pelas razões já expostas, o Direito como integridade oferece uma melhor concepção de Direito $^{51}$, porque além de atender à expectativa de segurança jurídica de maneira mais profícua que os demais, pautando-se pela coerência de princípios e não apenas por uma coerência estratégica, também, oferece possibilidade de transformação orgânica do Direito, que não fica engessado no tempo (convencionalismo) e nem além de seu tempo (pragmatismo), mas de acordo com ele, em uma visão conjunta do passado, presente e futuro da comunidade política.

\section{II.1.2. DiÁLOGO COM O POSITIVISMO JURÍDICO DE}

\section{H. L. A. HART}

Para que se conheça o conceito de Direito em Dworkin, além da caminhada já realizada no Capítulo anterior sobre o convencionalismo e o pragmatismo, que acabam por agregar conceitualmente uma série de outras correntes doutrinárias, respeitadas é claro as especificidades de cada uma delas (por exemplo, há identificação do convencionalismo com o positivismo jurídico, assim como do pragmatismo com o realismo legal), é fundamental estabelecer diálogo com o seu grande antagonista ${ }^{52}$ nesta empreitada, qual seja, o positivista

51 "A teoria dos direitos, elaborada por Dworkin, pode ser entendida como a tentativa de evitar as falhas das propostas de solução realistas, positivistas e hermenêuticas, bem como de esclarecer, através da adoção de direitos concebidos deontologicamente, como a prática da decisão judicial pode satisfazer simultaneamente às exigências de segurança do direito e da aceitabilidade racional." HABERMAS, Jürgen. Direito e democracia: entre facticidade e validade, vol. I, trad. Flávio Beno Siebeneichler, Rio de Janeiro: Tempo Brasileiro, 1997, p. 252

52 NEIL MACCORMICK esclarece que Dworkin foi sucessor de Hart na cadeira de filosofia do direito na Universidade de Oxford. Ele afirma que Hart foi ativo para que Dworkin fosse nomeado como o seu sucessor, pois ele era seu preferido, e de fato acabou sendo nomeado pela Universidade, mesmo sem ser conhecido à época. Todavia, a relação dos dois que, inicialmente, era muito boa, depois das duras críticas que Dworkin fez a ele, em suas obras, acabou sendo abalada, fato este do qual Dworkin se arrepende de acordo com MacCormick: "Nicola Lacey's biography also shows from private papers what an extent Hart's intellectual and personal relationship with Dworkin came to dominate his thought in his last years. In 1968, Hart had been unusually active, contrary, to the normal convention, in seeking to influence the appointment of his successor after retired (early) from the Oxford Jurisprudence Chair. Though still relatively little known in the United Kingdom, or even in the United States, Ronald Dworkin was his preferred candidate, and in due course Dworkin was indeed appointed. Yet after the most mutually cordial of beginnings, the atmosphere between them became, 
H. L. A. Hart ${ }^{53}$.

O diálogo foi construído em diversas obras, iniciou-se com a publicação do artigo Modelo de Regras ("The Model of Rules"), em 1967, o qual se encontra atualmente no livro Levando os direitos a sério ${ }^{54}$ de Dworkin, prosseguiu em Uma questão de princípio e em $O$ Império do Direito, tendo as críticas elencadas nestes livros sido respondidas por Hart no pós-escrito da sua obra $O$ Conceito de Direito. ${ }^{55} \mathrm{~A}$ esse respeito, é importante ressaltar que Hart faleceu antes de concluir o referido pós-escrito, cuja publicação ocorreu de maneira póstuma, então, não é possível saber se trata-se da versão final de suas considerações. Esse pós-escrito foi revisado e organizado por Joseph Raz e Penelope Bullock a pedido da família de Hart. ${ }^{56} \mathrm{O}$ debate direto, portanto, foi interrompido. Dworkin, mais de dez anos após a morte de Hart, que veio a falecer em 1992, tendo seu pós-escrito sido publicado em 1994, publica uma resposta ao pós-escrito hartiano, em $2004^{57}$, o qual foi, posteriormente, incluído na obra $A$ justiça de toga ${ }^{58}$. Frisa-se, novamente, que o debate sofreu uma

over time, one of mutual noncomprehension, and their early friendship cooled considerably. This was a matter of particular regret to Dworkin, whose intellectual disagreements with Hart never disrupted personal regard and indeed respect for the man and the thinker." MACCORMICK, Neil. H.L.A. Hart, 2a. ed., Stanford: Stanford University Press, 2008, p. 14

53 "Desejo examinar a solidez do positivismo jurídico, especialmente na forma poderosa que lhe foi dada pelo Professor H. L. A. Hart. Resolvi concentrar-me na sua posição não apenas devido a sua clareza e elegância, mas porque neste caso, como em quase todas as outras áreas da filosofia do direito, o pensamento que visa construir deve começar com um exame das concepções de Hart." DWORKIN, Ronald. Levando os direitos a sério, trad. Jefferson Luiz Camargo, São Paulo: Martins Fontes, 2007, p. 27

54 Trata-se do Capítulo 2 (Modelo de regras I) do livro Levando os direitos a sério.

55 "Mas, neste Pós-escrito, tentarei responder a algumas críticas de maior alcance feitas enfaticamente por Dworkin em muitos artigos seminais coletados em Taking Rights Seriously [Levando os direitos à sério] (1977) e A Matter of Principle [Uma questão de princípio] (1985) e no livro Law's Empire [O Império do Direito] (1986)." HART, H. L. A. O Conceito de Direito, trad. Antônio de Oliveira Sette-Câmara, São Paulo: Martins Fontes, 2009, p. 308

56 Conforme nota do revisor da obra a Justiça de toga de Dworkin, o qual, no Capítulo 6, referente ao pós-escrito, menciona a revisão e a organização deste manuscrito de Hart por Joseph Raz e Penelope Bullock. (DWORKIN, Ronald. A justiça de toga, trad. Jefferson Luiz Camargo, São Paulo: Martins Fontes, 2010, p. 199)

57 DWORKIN, Ronald. Hart's Postscript and the character of political philosophy, Oxford Journal of Legal Studies, vol. 24, n. ${ }^{\text {o }}$ 1, 2004

58 Trata-se do Capítulo 6 do livro A justiça de toga 
restrição no que se refere ao diálogo direto entre os autores, o que prejudica, consideravelmente, aquele que saiu do debate antes, no caso H. L. A. Hart. O direito de resposta acabou por restar nas mãos de comentadores ${ }^{59}$. Feitos estes esclarecimentos, passa-se à análise das concepções dos autores.

Hart afirma que seu objetivo com o livro "O Conceito de Direito" foi apresentar uma teoria que fosse geral e descritiva:

"É geral no sentido de que não se vincula a nenhum sistema jurídico ou cultura jurídica específicos, mas busca fornecer uma descrição explicativa e elucidativa do direito como instituição social e política complexa, dotada de um aspecto regulatório (e, nesse sentido, "normativo"). (...) Minha exposição é descritiva no sentido de que é moralmente neutra e não tem fins de justificativa: não busca justificar, com base em fundamentos morais ou outros, ou recomendar as formas e estruturas que aparecem em minha descrição geral do direito, embora uma compreensão clara destas constitua, a meu ver, uma condição preliminar importante para qualquer crítica moral frutífera do direito." 60

Nesse sentido, Hart acabaria por construir uma teoria diferente da de Dworkin, na medida em que (i) não se dirigiria a uma cultura jurídica específica (por exemplo, direito anglo-saxônico, ou direito romano-germânico), enquanto a teoria de Dworkin dirigir-se-ia, a princípio, aos anglo-saxões ${ }^{61}$, e (ii)

59 Por exemplo, pode-se mencionar: SCOTT J. SHAPIRO (The "Hart-Dworkin" Debate: a short guide for the perplexed, Public law and legal theory working paper series, University of Michigan Law School, working paper n. ${ }^{\circ}$ 77, março, 2007); BRIAN BIX (Jurisprudence Theory and Context, 5a ed., London: Sweet \& Maxwell Ltd., 2009, pp. 33-55); BRIAN LeITER (Beyond the Hart/Dworkin debate: The methodology Problem in Jurisprudence, American Journal of Jurisprudence, vol. 48, 2003, pp. 17-51); NeIL MACCORMICK (H.L.A. Hart, cit.)

60 HART, H. L. A. $O$ conceito de direito, cit., pp. 309-310

${ }^{61}$ Hart afirma em seu pós-escrito que seu trabalho é geral e descritivo não se vinculando a explicar a prática de seu próprio país, ao contrário, do que Dworkin faria, pois a teoria dele estaria vinculada aos anglo-saxões. "Meu objetivo neste livro foi apresentar uma teoria do direito que fosse ao mesmo tempo geral e descritiva. É geral no sentido de que não se vincula a nenhum sistema jurídico ou cultura jurídica específicos, mas busca fornecer uma descrição explicativa e elucidativa do direito como instituição social e política complexa, dotada de um aspecto regulatório. (...) diferente da concepção que dela faz Dworkin (que costuma chamá-la de jurisprudence): a seu ver, toda teoria do direito deve ter caráter parcialmente avaliativo e justificatório, bem como dirigir-se a uma cultura 
nem procuraria justificar esta prática jurídica, empreendendo apenas uma análise descritiva desta, enquanto Dworkin procuraria justificá-la moralmente. A esse respeito, é importante destacar que Dworkin discorda dessa neutralidade moral da teoria de Hart:

“(...) uma teoria geral sobre como o direito válido deve ser identificado, a exemplo da teoria do próprio Hart, não constitui uma descrição neutra da prática jurídica, mas uma interpretação dela que pretende não apenas descrevê-la, mas também justificá-la - mostrar por que a prática é valiosa e como deve ser conduzida de modo a proteger e enfatizar esse valor. (...) os argumentos jurídicos habituais têm a mesma natureza: um juiz ou um cidadão que precisa decidir o que é o direito quando se vê diante de alguma questão complexa, deve interpretar o direito do passado para descobrir quais princípios melhor o justificam, e, em seguida, decidir o que tais princípios exigem no novo caso. Portanto, uma teoria do direito de um filósofo do direito não é diferente, em sua natureza - embora seja, sem dúvida, bem mais abstrata -, das alegações jurídicas comuns que os advogados fazem nos casos em que atuam."62

Dworkin rechaça esse pretensioso propósito descritivo/neutro da teoria hartiana com base em considerações metodológicas: afirma que não é possível chegar a alguns conceitos, como liberdade, igualdade, justiça etc, sem considerar valores; na medida em que estes são conceitos interpretativos (não há consenso sobre o seu significado), cuja melhor descrição depende necessariamente de se recorrer a valores ${ }^{63}$. Dworkin complementa esta posição

jurídica específica, geralmente a do próprio teórico, e que, no caso de Dworkin, é a do direito anglo-saxão.” g.n. (HART, H.L.A. O conceito de direito, cit., p. 310.) Dworkin refuta esta afirmação de que sua teoria aplicaria-se apenas ao seu país: "Os críticos ingleses afirmam frequentemente que meu projeto tem inspiração provinciana - que pretende apenas explicar a prática jurídica de meu país - ou que é claramente provinciano em seus resultados, porque de algum modo se pode perceber, sem grandes reflexões ou pesquisas, que ele só se ajusta a essa prática jurídica. Na verdade, minha exposição aspira a uma grande generalidade, e em que medida esse objetivo é bem-sucedido é algo que só pode ser avaliado por um trabalho muito mais exaustivo de interpretação jurídica comparativa do que o que foi realizado por esses críticos.” (DWORKIN, Ronald. A justiça de toga, cit., p. 262)

62 DWORKIN, Ronald, A justiça de toga, cit., p. 200

63 "Os conceitos de liberdade, democracia etc. Funcionam, no pensamento e no discurso comuns, como conceitos interpretativos de valor: seu sentindo descritivo é contestado, e a contestação gira em torno de qual especificação de um sentido descritivo melhor apreende e melhor dá conta desse valor. O 
afirmando que nem todos os conceitos são determinados por critérios comuns (antecedentes factuais), especialmente, os conceitos políticos (por exemplo, Democracia, liberdade etc). ${ }^{64}$ Nesse sentido, pode-se afirmar que, segundo Dworkin, a teoria que Hart pretende desenvolver sobre o Direito apresenta severas falhas em seus pressupostos.

A teoria de Hart, como pretende ser descritiva ${ }^{65}$, adota uma visão empírica do Direito, como se tudo que dissesse respeito a ele já estivesse construído e não a construir, tudo fosse fatos sobre os quais se atribuiria algum significado $^{66}$, mas que este deveria ser despretensioso, isto é, não deveria visar algum objetivo, nem ter algum valor que justificasse o Direito - contrariamente ao que Dworkin defende ${ }^{67}$. O olhar de Hart volta-se para o passado. A prática

significado descritivo não poder ser removido da força valorativa porque o primeiro depende do segundo desse modo particular.” DWORKIN, Ronald. A justiça de toga,cit., p. 212

64 "A sugestão semântica pressupõe determinados antecedentes factuais. Pressupõe que o uso de "liberdade", "democracia" e outros nomes de conceitos políticos é regido - em nossa linguagem por critérios comuns que determinam se um uso é correto ou incorreto, ou se fica em alguma área limítrofe entre os dois. (...) Esses pressupostos semânticos são plausíveis em alguns casos: quando estamos estudando o conceito de artefato, por exemplo. (...) Alguns filósofos cometeram o erro, acredito, de pensar que todos os conceitos são regidos dessa maneira por critérios comuns, ou, pelo menos, o erro de pressupor, de um ponto de vista acrítico, que os conceitos que eles estudam são regidos desse modo. Porém, muitos conceitos são de natureza diversa, inclusive aqueles de maior importância para os filósofos políticos." DWORKIN, Ronald. A justiça de toga, cit., pp. 213-214

65 Essa pretensão descritiva do Direito é tradicional nas escolas analíticas, a qual, no Direito anglosaxão, ganhou grande projeção com JoHn AUSTIN e foi, também, adotada por H. L. A. HART. De acordo com ALBERT CALSAMIGLIA, Dworkin contesta esta visão da teoria do Direito, enquanto mera descrição: "El puento de vista de Austin y de sus seguidores supone que el derecho es un producto acabado y que el científico del derecho tiene un objetivo fundamental: describir y explicar ese derecho. El científico es un descriptor de ese producto. Las teorías jurídicas de Kelsen y Hart están en esa línea y constituyen las versiones más sofisticadas del paradigma austiano. La osadía de Dworkin consiste em poner em cuestión esse paradigma. (...) la tarea de la ciencia jurídica no es describir el derecho desde fuera, sino ofrecer solución a los problemas que se plantea" CALSAMIGLIA, Albert. El concepto de integridad em Dworkin, cit., p. 158

66 Essa atribuição de significado pode ser considerada um avanço na teoria de Hart, que abarca a dimensão da interpretação no conceito do Direito, embora não considere que esta deva justificar algo, ou visar algum objetivo, que não a própria interpretação semântica dos antecedentes factuais. Ocorre que, como foi explanado no texto principal, em alguns conceitos extremamente relevantes ao Direito (como a liberdade, a igualdade, a Democracia etc) não se consegue chegar a um consenso com base em critérios prévios (antecedentes factuais).

67 "As pessoas agora tentam impor um significado à instituição - vê-la em sua melhor luz - e, em seguida, reestruturá-la à luz desse significado. Os dois componentes da atitude interpretativa são independentes um do outro; podemos adotar o primeiro componente dessa atitude com relação a alguma instituição sem que seja necessário adotar também o segundo. É o que fazemos nos casos de 
jurídica atual, o seu propósito, ou sua melhor justificativa, não seriam relevantes na sua conceituação, que pretende ser apenas teórica. Dworkin discorda dessa suposta construção avalorativa do Direito em Hart, isto é, de uma descrição sem justificação.

A respeito da mencionada relação entre teoria e prática jurídica, importa salientar que, para Dworkin, ambas caminham juntas na construção do conceito de Direito. É impossível, nesse sentido, entender o significado do conceito de Direito, na concepção de Dworkin, se não adotar essa visão conjunta, construtiva do Direito, em que são aliadas a prática e a teoria. Diferentemente de Hart, o passado, o presente e o futuro caminham juntos na conceituação do Direito na teoria de Dworkin. A referida aliança entre teoria e prática será melhor demonstrada no Capítulo II.2, referente à teoria da decisão judicial. Por ora, prossegue-se no adensamento conceitual da obra de Hart.

Ao aprofundar a leitura da obra de Hart, percebe-se que ele se esforçou para seguir o seu propósito analítico na construção da sua teoria do Direito e, nesta empreitada, estabeleceu critérios para distinguir as regras jurídicas, criando duas categorias principais: as regras primárias e as regras secundárias $^{68}$. Esta distinção é essencial na sua teoria do Direito, levando Dworkin a afirmar que "o conceito de direito de Hart é uma construção a partir

jogos e competições. Recorremos à finalidade dessas práticas ao discutirmos a possibilidade de alterar suas regras, mas não (a não ser em casos muito raros) aquilo que elas são no momento; isso é determinado pela história e pela convenção. A interpretação, portanto, desempenha um papel apenas exterior nos jogos e competições. Contudo, é fundamental para a minha fábula sobre a cortesia que as pessoas da comunidade hipotética adotem o segundo componente dessa atitude, bem como o primeiro; para eles, a interpretação decide não apenas por que a cortesia existe, mas também o que, devidamente compreendida, ela agora requer. Valor e conteúdo se confundem.” DWORKIN, Ronald. O império do direito, cit., p. 58

68 A professora ElZA BoITEUX esclarece que a teoria proposta por Hart estabelece: "A existência do sistema jurídico depende de dois tipos de regras: das primárias, que impõem obrigações, e das secundárias que outorgam poderes aos particulares e autoridade públicas para criar, modificar, extinguir ou determinar os efeitos das regras primárias.” BOITEUX, Elza A. Pereira Cunha. A função ética da pena privada, Tese de livre-docência em Filosofia e Teoria Geral do Direito, Universidade de São Paulo, 2010, p. 42 
dessas várias distinções. ${ }^{69,}$

As regras primárias estabelecem direitos e obrigações aos membros da comunidade política, enquanto as regras secundárias dizem respeito a como e quem pode estabelecer e alterar essas regras ${ }^{70}$, ou seja, referem-se ao processo de formação das regras primárias. Pela teoria de Hart, as regras para serem consideradas obrigatórias precisam ter "autoridade", que pode advir tanto (i) de uma aceitação por parte dos membros da comunidade política de certa prática reiterada, um costume, por exemplo; ou (ii) da observância do processo estabelecido na regra secundária. Nesse sentido, Dworkin afirma que para Hart "uma regra pode ser obrigatória (a) porque é aceita ou (b) porque é válida.",71

Na teoria de Hart, só existe Direito se houver uma regra que permita a identificação de uma norma como jurídica. Se não houver um critério de distinção entre normas jurídicas e sociais, estar-se-ia em uma comunidade primitiva, em que apenas há regras primárias, oriundas da aceitação. O Direito para ser Direito, na teoria de Hart, exige a existência de norma de reconhecimento $^{72}$, que permita saber se uma norma é válida, ou inválida, pertencente, ou não, ao sistema jurídico. Com esse propósito de verificação da validade das normas, Hart desenvolve o conceito de regra de reconhecimento:

DWORKIN, Ronald. Levando os direitos a sério, cit., p. 33

DWORKIN, Ronald. Levando os direitos a sério, cit., p. 31

DWORKIN, Ronald. Levando os direitos a sério, cit., p. 33

72 Embora haja semelhanças, Hart esclarece que sua concepção de norma de reconhecimento distinguese da concepção kelseniana de norma fundamental (grundnorm), especialmente, porque: (i) a norma de reconhecimento decorre de um processo empírico complexo, havendo desse modo um apelo forte ao aspecto factual, enquanto a norma fundamental de Kelsen é hipotética; (ii) não se "pressupõe a validade" da norma de reconhecimento, "aceita-se" a norma de reconhecimento, portando, a ideia de validade não se aplica a norma de reconhecimento; enquanto, na norma fundamental de Kelsen, está pressuposta a sua validade; e (iii) a norma de reconhecimento varia conforme a cultura políticojurídica de cada povo, enquanto a norma fundamental de Kelsen teria sempre o mesmo conteúdo. (HART, H.L.A., O conceito de direito, cit., pp. 375-376) 
"Num sistema jurídico moderno, no qual existem várias "fontes" do direito, a norma de reconhecimento é correspondentemente mais complexa: os critérios para identificar a norma jurídica são múltiplos e geralmente incluem uma constituição escrita, a promulgação pelo legislativo e precedentes judiciais. Na maioria dos casos, há mecanismos destinados a solucionar possíveis conflitos, hierarquizando-se esses critérios segundo uma ordem de subordinação e primazia relativas. (...) No cotidiano de um sistema jurídico, é muito raro que sua norma de reconhecimento seja expressamente formulada como norma. (...) Em geral, a norma de reconhecimento não é explicitamente declarada, mas sua existência fica demonstrada pela forma como se identificam normas específicas, seja pelos tribunais ou outras autoridades, seja por indivíduos particulares ou seus advogados e assessores jurídicos. (...) Dizer que determinada norma é válida equivale a reconhecer que esta satisfaz a todos os critérios propostos pela norma de reconhecimento e é, portanto, uma norma do sistema."73

"Afirmava que os verdadeiros fundamentos do direito encontram-se na aceitação, por parte da comunidade como um todo, de uma regra-mestra fundamental (que ele chamou de "regra de reconhecimento") que atribui a pessoas ou grupos específicos autoridade de criar leis. Assim, as proposições jurídicas não são verdadeiras apenas em virtude da autoridade de pessoas que costumam ser obedecidas, mas, fundamentalmente, em virtude de convenções sociais que representam a aceitação, pela comunidade, de um sistema de regras que outorga a tais indivíduos ou grupos o poder de criar leis válidas." 74

A regra de reconhecimento, como apontado nos excertos selecionados, varia de acordo com a comunidade política, pode-se estabelecer critérios diferentes que se adéquem à cultura político-jurídica de um determinado povo, no reconhecimento da validade de suas normas. A regra de reconhecimento permite verificar a validade das normas, embora ela mesma não seja válida e sim aceita. ${ }^{75}$

HART, H. L. A., O conceito de direito, cit., pp. 130-133

74 DWORKIN, Ronald. $O$ império do direito, cit. p. 42

75 "Sem dúvida, uma regra de reconhecimento não pode ser ela mesma válida, de vez que, por hipótese, 
A respeito desta temática, Dworkin aponta uma contradição na teoria de Hart, qual seja, a ideia de que a regra de reconhecimento, em tese, validaria todas as regras do sistema jurídico. A contradição residiria na aceitação de Hart dos costumes como regras obrigatórias de uma comunidade. Ou seja, sua obrigatoriedade não decorre de sua validade, de terem sido tais costumes elaborados em conformidade a uma regra secundária, mas de serem eles aceitos pela comunidade política. Nesse sentido, Dworkin afirma que:

\begin{abstract}
"A regra suprema, diz Hart, marca a transformação de uma sociedade primitiva em uma sociedade regida pelo direito, porque fornece um teste para determinar quais são as regras jurídicas da sociedade, em vez de medi-las por sua aceitação. Mas, se a regra suprema simplesmente afirma que quaisquer outras regras aceitas pela sociedade como juridicamente obrigatórias são juridicamente obrigatórias, então ela de modo nenhum fornece um teste, além do teste que deveríamos aplicar caso não houvesse regra suprema. (...) Na verdade, o tratamento dado por Hart ao costume equivale a uma confissão de que existem pelo menos algumas regras de direito que não são obrigatórias, tal como a regra suprema - porque são aceitas como obrigatórias pela comunidade. Isso reduz a fragmentos a elegante arquitetura piramidal que admiramos na teoria de Hart: não podemos mais afirmar que apenas a regra suprema é obrigatória em razão de sua aceitação e que todas as demais regras são válidas nos termos da regra suprema."
\end{abstract}

ela é a última instância e não pode, portanto, satisfazer os testes estipulados por uma regra ainda mais fundamental. A regra de reconhecimento é a única regra em um sistema jurídico cuja obrigatoriedade depende de sua aceitação." (DWORKIN, Ronald. Levando os direitos a sério, cit., p. 34). No mesmo sentido, JÜRGEN HABERMAS, sobre a regra de reconhecimento de Hart, esclarece que: "A legitimação da ordem jurídica em sua totalidade é transportada para o início, isto é, para uma regra fundamental ou regra do conhecimento, a qual legitima tudo, sem ser, porém, passível de uma justificação racional; ela tem que ser assimilada faticamente como parte de uma forma de vida histórica, portanto conforme o costume. Hart procura explicar isso utilizando-se do conceito de "jogo de linguagem", de Wittgenstein. Do mesmo modo que a gramática de um jogo de linguagem, a regra do conhecimento está enraizada numa prática descrita a partir de fora como fato, a qual, porém, "é aceita" como auto-evidência cultural "e suposta como válida" pelos próprios participantes.”(HABERMAS, Jürgen. Direito e democracia: entre facticidade e validade, cit., p. 251)

76 DWORKIN, Ronald. Levando os direitos a sério, cit., pp. 68-69 
Esta pode representar uma grande falha no sistema piramidal proposto por Hart, na medida em que este autor admite que a obrigatoriedade de uma regra pode decorrer da sua aceitação pela comunidade política, o que retiraria a força e utilidade da regra de reconhecimento, uma vez que ela não seria capaz de testar para diferenciar o jurídico do não jurídico, em diversas situações.

Dando prosseguimento ao diálogo com Dworkin, Hart afirma em seu pós-escrito que o conceito de regra de reconhecimento por ele elaborado foi mal interpretado por Dworkin, cuja obra Levando os direitos a sério parece limitá-lo ao teste de pedigree (maneira como as leis são criadas, modificadas, alteradas, revogadas etc., pelas instituições jurídicas). Hart defende que sua regra de reconhecimento não se limita a esse teste e pode, em alguns sistemas jurídicos, ter como critério princípios de justiça e valores morais ${ }^{77}$ substantivos:

“(...) embora meus principais exemplos dos critérios oferecidos pela norma de reconhecimento envolvam aquilo que Dworkin chamou de "pedigree", ocupando-se apenas com a maneira como as leis são adotadas ou criadas pelas instituições jurídicas e não com seu teor, declaro expressamente, (...) que, em alguns sistemas jurídicos, como nos Estados Unidos, os critérios últimos de validade jurídica podem incorporar explicitamente, além do pedigree, princípios de justiça ou valores morais substantivos, e estes podem integrar o conteúdo das restrições jurídicas constitucionais. (...) nada há em meu livro que sugira que só critérios factuais oferecidos pela norma de reconhecimento devam se restringir às questões de pedigree;

77 NEIL MACCORMICK, nesse sentido, parece tentar compatibilizar a regra de reconhecimento hartiana com os princípios, sob o argumento de que é relevante conhecer quais regras são válidas, conforme a regra de reconhecimento, para, então, identificar os princípios, que podem ser tidos como jurídicos: "Em suma, quando perguntamos o que confere a um princípio uma qualidade jurídica, devemos dar a resposta em termos de sua função real ou potencial de explanação ou justificação diante da lei como já está estabelecida, ou seja, em relação a normas estabelecidas do direito conforme identificadas por referência a critérios de reconhecimento. Isso é perfeitamente compatível com a proposição igualmente verdadeira de que no processo de criação de leis é a adesão do povo a princípios morais e políticos que lhes dá razão para promulgar ou enunciar judicialmente leis ou deliberações jurídicas.” MACCORMICK, Neil. Argumentação Jurídica e Teoria do Direito, cit., pp. 310-311 
podem, ao contrário, constituir restrições substantivas ao conteúdo da legislação, como a Décima Sexta ou a Décima Nona Emendas à Constituição norte-americana, sobre o estabelecimento de religiões ou do direito de voto."78

Como se pôde verificar, Hart afirma que sua regra de reconhecimento não se limita a um aspecto formal, que estabeleceria como as leis devem ser adotadas, modificadas, ou criadas pelas instituições competentes, mas que, também, teria uma preocupação com o seu conteúdo, ou seja, que consideraria princípios morais e valores substantivos da comunidade política.

Dworkin afirma ser impossível haver uma regra de reconhecimento que permitiria distinguir uma regra e princípios morais das regras e princípios jurídicos, ou seja, a tentativa de Hart de afirmar que sua regra de reconhecimento poderia abarcar princípios morais e valores substantivos da comunidade política parece não ser bem sucedida em sua empreitada:

\begin{abstract}
"A primeira tese sustenta que, em todos os países que têm um sistema jurídico desenvolvido, existe, na comunidade de seus juízes e autoridades judiciárias, alguma regra social ou conjunto de regras que determinam os limites do dever, por parte do juiz, de reconhecer qualquer outra regra ou princípio como direito. (...) A questão é importante; dela depende a ideia ortodoxa de que os padrões jurídicos podem, em princípio e como grupo, ser distinguidos de padrões morais e políticos. Se a primeira tese fosse correta, existe realmente em todo sistema jurídico algum teste de direito comumente aceito, na forma de uma regra social, e isto é suficiente para distinguir regras e princípios morais de regras e princípios jurídicos."79
\end{abstract}

Realmente, a regra de reconhecimento pode operar bem nos casos que exijam apenas o teste de pedigree de uma norma, isto é, na averiguação se uma norma está, ou não, conforme o estabelecido no processo de formação,

8 HART, H.L.A., O conceito de direito, cit., pp. 319-324

79 DWORKIN, Ronald. Levando os direitos a sério,cit., pp. 95-96 
alteração, revogação etc. desta, mas a regra de reconhecimento parece não ser satisfatória nos casos que envolvam questões controversas, difíceis, na medida em que não tem aptidão para trabalhar com princípios. Por mais que Hart afirme que sua norma de reconhecimento tenha essa consideração aos princípios morais e valores substantivos da comunidade, não apresenta o filósofo mecanismos efetivos sobre como ela operaria em termos práticos, até porque, questões difíceis, por óbvio, levantam muitas controvérsias, não apresentam consenso entre os membros da comunidade, o que torna mais complicada a situação da regra de reconhecimento que, como já foi explanado, na teoria de Hart, depende de "aceitação" enquanto regra social para ser considerada enquanto tal. Se há forte dissenso na comunidade política, não é possível afirmar a sua aceitação ${ }^{80}$.

\section{Por outro lado, Dworkin reconhece o esforço de Hart ao afirmar a} moral enquanto critério para a identificação do Direito em alguns casos, ou seja, poderia ser fonte do Direito e reafirma o dissenso nessas questões (inviabilizador de uma regra de reconhecimento):

80 A respeito da regra de reconhecimento e o debate entre Hart-Dworkin, no que se refere aos casos difíceis, ANDREI MARMOR esclarece que, como no positivismo legal de Hart, a validade das normas depende do consenso e tem como regra mestra a norma de reconhecimento, segundo a qual se verifica esta validade, nos casos controversos, nos quais não há consenso, não haveria norma obrigatória (válida) para decidir a questão: “According to legal positivism, the conditions of legal validity are determined by social rules and conventions prevalent in a given community. These conventions indentify which actions or procedures create the law, or in other words, they identify the source of law. An additional thesis of legal postivism is that the law is essentially source based. This means that a norm cannot be legally valid unless it derives its validity from one of the source identified by the pertinent conventional rules. (Hart has further maintained that in any given legal system these conventions can be formulated by one master rule, the Rule of Recognition.) Now, according to Dworkin, this conventional account of law's validity cannot explain how the law is able to impose obligations in controversial cases. Conventions, Dworkin assumes, manifest a pattern of agreement, a convergence of beliefs; once their application turns out to be controversial there are no grounds for further argument on the basis of these conventions, as ex hypothesis, they have exhausted their binding force. Hence on this conventional theory of law, there is no binding law in controversial cases. But this latter conclusion, Dworkin argued, cannot be maintained. Lawyers and judges regard numerous norms as legally binding, despite their undeniably controversial nature. Thus his conclusion that because legal positivism is committed to the view that law is uncontroversial, legal positivism is patently false." MARMOR, Andrei. Interpretation and legal theory, 2a ed., Oxford: Hart Publishing, 2005, pp. 7-8 
"Hart afirmou que a moral se torna pertinente para a identificação do direito quando alguma "fonte" tiver determinado que ela deve exercer esse papel, citando as cláusulas constitucionais abstratas da Constituição norteamericana como exemplo. Mas ele interpretou mal a situação do direito constitucional norte-americano. Não existe consenso nem a favor nem contra a interpretação moral da Constituição: ao contrário, essa questão é objeto de feroz divergência. (...) Não há consenso geral a favor ou contra tal interpretação, nenhuma regra fundamental de reconhecimento a partir da qual um dos lados possa pretender corroborar as proposições de direito constitucional que, não obstante, cada um dos grupos afirma serem verdadeiras." 81

Portanto, a regra de reconhecimento de Hart não é útil ao se trabalhar com casos difíceis, em que o dissenso, dada a complexidade das questões envolvidas, está sempre presente. A ausência de regras claras (normas em que há consenso) para resolver a questão, na teoria de Dworkin, exige do intérprete que este alce voo sobre o nebuloso campo da moral. $\mathrm{O}$ alçar voo sobre o campo da moral não é algo consensual no direito norte-americano ${ }^{82}$ e, por isso, não poderia fazer parte de uma regra de reconhecimento. Nesse sentido, pode-se dizer que o coração da teoria do Direito de Hart - a regra de reconhecimento - não soluciona de maneira satisfatória o problema dos casos difíceis, pois não há, verdadeiramente, como esclarece Dworkin, regra de reconhecimento que abarque aspectos morais e valorativos da comunidade política.

Para finalizar as considerações sobre o diálogo travado entre Hart e Dworkin, e dar o devido encaminhamento ao Capítulo seguinte (II.1.3. Diferença entre regras, princípios e políticas), destaca-se a questão das fontes do Direito.

81 DWORKIN, Ronald, A justiça de toga, cit., p. 238

82 Essa consideração de Dworkin sobre a falta de consenso quanto a recorrer a questões morais para resolver casos difíceis, também, se aplica à doutrina nacional (Brasil). 
A compreensão do que são as fontes do Direito e se estas incluem padrões, que não são regras, influem, diretamente, em como se julga um caso prático, e assume peculiar relevância nos casos difíceis nos quais não há regras previamente estabelecidas para resolvê-los. Os positivistas como Hart afirmam que se deve, nos casos difíceis, recorrer à discricionariedade, ou seja, o juiz cria um direito novo e aplica retroativamente às partes $^{83}$ (Capítulo II.3.2. O poder discricionário do juiz); enquanto, por outro lado, Dworkin afirma ser possível resolver a questão com base no Direito já existente ${ }^{84}$.

Na teoria de Hart, os princípios não são capazes de gerar direitos e obrigações jurídicas ${ }^{85}$, ou seja, permitir que uma pessoa ganhe, ou perca, uma causa com base nele, a não ser que tenham sido expressamente positivados ${ }^{86}$

83 DWORKIN, Ronald. Levando os direitos a sério,cit., p. 127

84 Albert CALSAMiglia, importante professor na expansão do pensamento de Dworkin em território espanhol, reitera a posição de que a teoria proposta por Dworkin não se baseia na possibilidade de criação de Direito pelos juízes, ao contrário, as decisões devem se basear em direitos preexistentes, embora estes não estejam todos positivados: "Por último, cabría destacar que frente a la tesis de la función creadora de derecho del juez - función política por excelencia - Dworkin mantiene que la función judicial es dar el triunfo al derecho más fuerte y que por tanto deben garantizar derechos preestabelecidos y no crearlos. Esta tesis garatinzadora es más coherente con el sistema de legitimación del estado de dercho que no permite las leyes retroactivas ni tolera poderes políticos paralelos a los órganos representativos.” (g.n.) CALSAMIGLIA, Albert. ¿Por qué es importante Dworkin?, Doxa: Cuadernos de Filosofía del Derecho, nº 2, 1985, p. 163

85 "Uma interpretação dos princípios tal como eles realmente funcionam na prática (fit) deve reconhecer que os princípios não são meros guias para o exercício de uma atividade discricionária nem são vinculantes em razão de seu pedigree autoritativo. O positivismo jurídico fracassa justamente por não reconhecer esse aspecto importante do funcionamento dos princípios. (...) Poder-se-ia alegar que os princípios e, mais ainda, os conflitos entre princípios sempre envolvem uma controvérsia e, por tal motivo, não teriam conteúdo objetivo. Pela mesma razão, eles não poderiam criar obrigações para os operadores do direito. A isso Dworkin responderá (como se verá com mais detalhe adiante) que a interpretação dos princípios, apesar de frequentemente envolver controvérsia, possui um conteúdo cognitivo objetivo. Evidentemente, trata-se de uma objetividade não redutível a uma concepção absoluta do mundo nem tampouco redutível a critérios de verificação fisicalistas, conforme se procurou demonstrar em capítulos anteriores. Esse argumento exigirá, entretanto, o desenvolvimento de uma teoria da controvérsia capaz de mostrar como a objetividade é possível mesmo quando há desacordo - e, portanto, numa situação em que inexiste convenção que estabeleça os sentidos dos princípios e regras." (g.n.) MACEDO JUNIOR, Ronaldo Porto. Do xadrez à cortesia: Dworkin e a teoria do direito contemporânea, Tese de livre-docência em Filosofia e Teoria Geral do Direito, Universidade de São Paulo, 2012, p. 119

86 "Em minha opinião, o argumento jurídico é um argumento típica e completamente moral. Os juristas devem decidir qual desses conjuntos concorrentes de princípios oferece a melhor justificação da prática jurídica como um todo, isto é, que seja mais peremptória em termos morais. Por outro lado, segundo a tese das fontes de Hart, o argumento jurídico substantivo só é normativo quando as fontes 
pelas instituições políticas competentes; caso não tenham sido, apenas as regras, que passaram pelo crivo da regra de reconhecimento, teriam este papel. Portanto, na hipótese de lacuna, de não haver uma norma positivada a regular o caso, Hart propõe que se recorra ao poder discricionário do juiz para decidi-lo (conforme Capítulo II.3.2. , infra). Nesse sentido, Dworkin afirma que a teoria de Hart não consegue dar uma solução satisfatória aos casos difíceis:

\begin{abstract}
"Nos termos de sua própria tese, o positivismo não chega a enfrentar esses casos difíceis e enigmáticos que nos levam à procura de teorias do direito. Quando lemos esses casos, o positivista nos remete a uma teoria do poder discricionário que não leva a lugar algum e nada nos diz. Sua representação do direito como um sistema de regras tem exercido um domínio tenaz sobre nossa imaginação, talvez graças a sua própria simplicidade. Se nos livrarmos desse modelo de regras, poderemos ser capazes de construir um modelo mais fiel à complexidade e sofisticação de nossas práticas. ${ }^{~}{ }^{87}$
\end{abstract}

Por fim, para concluir o presente Capítulo, importa salientar que os casos fáceis, nos quais regras expressas regulam uma dada situação, a divergência entre os autores não se revela de maneira contundente; todavia, no que se refere aos casos difíceis, Dworkin levanta fortes argumentos no sentido de revelar a inconsistência e inadequação da solução apresentada pelo positivista, na medida em que sua teoria piramidal, pautada pela regra de reconhecimento, não conseguiria lidar com questões difíceis, recorrendo ao poder discricionário dos juízes ${ }^{88}$, de modo a desconsiderar todo o esforço positivista de dar segurança ao sistema jurídico construído pelas regras.

sociais tornam os critérios morais parte do direito.” DWORKIN, Ronald. A justiça de toga,cit. p. 205

88 Como já foi mencionado, a questão do poder discricionário dos juízes, como forma de resolução dos casos difíceis apresentada por Hart, será trabalhada em Capítulo próprio - II.3.2. O poder discricionário do juiz. 


\section{II.1.3. DIFERENÇA ENTRE REGRAS, PRINCÍPIOS E POLÍTICAS}

Em uma primeira etapa, foi realizada a conceituação do Direito como integridade, diferenciando-o de importantes correntes antagonistas selecionadas pelo próprio Dworkin em sua obra - o convencionalismo e o pragmatismo. Para aprofundar a distinção e, ao mesmo tempo, a afirmação do Direito enquanto integridade como o melhor conceito de Direito para uma verdadeira comunidade política confrontou-o com o positivismo de H. L. A. Hart, importante antagonista de Dworkin. Como fechamento deste Capítulo sobre o "Conceito de Direito para Ronald Dworkin" e, também, como forma de introdução ao Capítulo que se segue a este sobre a "Teoria da Decisão Judicial de Dworkin", recorremos à última etapa deste percurso, qual seja, estabelecer a distinção entre regras, princípios e políticas. A forma como esses três elementos afetam o processo decisório será construída no Capítulo seguinte. O propósito deste Capítulo é apenas pontuar as principais distinções.

Antes de iniciar as distinções, destaca-se que elas ainda permanecem relevantes ao debate que aqui se pretende empreender, embora Dworkin tenha refinado suas críticas ao positivismo jurídico por um viés metodológico, em seus últimos trabalhos ${ }^{89}$, a relevância desta distinção e o que isso representou quando de sua publicação, em 1967, ainda são válidas. Segundo Stephen Guest, este artigo fez a reputação de Dworkin no meio acadêmico, e mesmo com a mudança de ênfase das obras mais recentes do autor, ele não perdeu sua força inicial e permanece importante à teoria de Dworkin ${ }^{90}$.

\footnotetext{
A esse respeito, menciona-se a obra a Justiça de toga e Justice for hedgehogs

90 "It was the publication of "The model of rules" in the University of Chicago Law Review that made his reputation. This article has three characteristic features of his later writing. It is very well written, having energy and journalistic clarity, it contains a brilliantly clear summary of the main tenets of $\mathrm{H}$. L. A. Hart's The Concept of Law and above all, it presents a sustained, original and constructive attack on the thesis contained in that book. The article, now appearing as Chapter 2 of Taking Right
} 
Feito esse esclarecimento, passa-se à análise da distinção.

Dworkin denomina princípios como:

“(...) um padrão que deve ser observado, não porque vá promover ou assegurar uma situação econômica, política ou social considerada desejável, mas porque é uma exigência de justiça ou equidade ou alguma outra dimensão de moralidade" ${ }^{11}$

Enquanto política seria:

“(...) aquele tipo de padrão que estabelece um objetivo a ser alcançado, em geral uma melhoria em algum aspecto econômico, político ou social da comunidade (ainda que certos objetivos sejam negativos pelo fato de estipularem que algum estado atual deve ser protegido contra mudanças adversas). ${ }^{.92}$

Logo se verifica, com as definições acima trazidas, que os princípios não visam um objetivo circunstancial de ordem política, ou econômica, mas pretendem atender a algo maior concernente à moralidade política da comunidade, que supera esses interesses momentâneos. A partir dessa consideração, é possível afirmar que os princípios de uma comunidade política são mais sólidos e, portanto, mais perenes que as políticas, na medida em que estas atendem a estes objetivos circunstanciais.

Quanto às regras, na teoria de Dworkin, a diferença com os princípios é de natureza lógica ${ }^{93}$. Explica-se: as regras teriam uma clara

Seriously, has not lost its initial force and although there are changes of emphasis in his later theory the emerging theses is clear and, I believe, mostly unchanged." GUEST, Stephen. Ronald Dworkin, cit., pp. 12-13

92 DWORKIN, Ronald. Levando os direitos a sério, cit., p. 36

93 A esse respeito, HABERMAS esclarece que "Regras e princípios também servem como argumentos na fundamentação das decisões, porém o seu valor posicional na lógica da argumentação é diferente. 
aplicação a um dado caso prático, operando ao que Dworkin denomina de "tudo-ou-nada", como em um jogo, no qual os movimentos do jogador têm consequências conhecidas por todos. Ou a regra se aplica, ou ela não se aplica, não existe meio-termo ao se operar com regras. Elas até podem prever exceções, mas estas devem ser expressas.

Os princípios, por outro lado, operam de maneira oposta. Não se pode afirmar, previamente, se uma dada ação terá uma consequência jurídica $x$ ou y com base nos princípios elencados. Não é uma operação automática de verificação de uma causa e atribuição de uma consequência, como ocorrem com as regras.

\begin{abstract}
"A diferença entre princípios jurídicos e regras jurídicas é de natureza lógica. (...) As regras são aplicáveis a maneira do tudo-ou-nada. (...) Mas não é assim que funcionam os princípios apresentados como exemplos nas citações. Mesmo aqueles que mais se assemelham a regras não apresentam consequências jurídicas que se seguem automaticamente quando as condições são dadas." 94
\end{abstract}

Considerado o acima exposto, que os princípios não se aplicam automaticamente a um dado caso concreto como as regras, deve-se apresentar, então, o que deve ser considerado, ou levado em conta, para aplicar um princípio concretamente. Nesse sentido, Dworkin esclarece que os princípios

Pois regras contêm sempre um componente "se", que especifica as condições de aplicação típicas da situação, ao passo que princípios, ou surgem com uma pretensão de validade não-específica, ou são limitados em sua esfera de aplicação através de condições muito gerais, em todo caso carentes de um interpretação. Pode-se explicar a partir daí a diferença característica entre regras e princípios no que tange à atitude de coalisão, que Dworkin coloca em relevo. Só se pode solucionar um conflito entre regras, introduzindo uma cláusula de exceção ou declarando uma das regras conflitantes como inválida. Ora, no conflito entre princípios, não se faz necessária uma decisão de tipo "tudo ou nada". É certo que um determinado princípio goza de primazia, porém não a ponto de anular a validade dos princípios que cedem o lugar. Um princípio passa à frente do outro, conforme o caso a ser decidido. No desenrolar dos casos, estabelece-se entre os princípios uma ordem transitiva, sem que isso arranhe sua validade." HABERMAS, Jürgen. Direito e democracia: entre facticidade e validade, cit., pp. 258-259

94 DWORKIN, Ronald. Levando os direitos a sério,cit., p. 40 
têm a dimensão do peso e da importância na sua aplicação prática, o que não permite uma resposta (ou consequência jurídica) prévia. Em um caso, um princípio assume um papel central de relevância e prepondera sobre outro; em uma situação diversa, pode ocorrer o contrário.

Dworkin diferentemente de alguns autores ${ }^{95}$, ao distinguir princípios de regras, não esclarece de imediato qual seria o seu "método" de aplicação dos princípios (ponderação, razoabilidade etc). Ao longo da leitura de sua obra, pode-se constatar que a escolha de um princípio, em detrimento de outro, na aplicação em um caso concreto, decorre da análise de qual decisão melhor atende à concepção do Direito como integridade, que não é propriamente um método exclusivo aos princípios, aplicando-se às questões jurídicas como um todo. Esta análise será detalhada no Capítulo II.3.1., referente às etapas da interpretação e ao método de Hércules.

Os princípios são, especialmente, relevantes para a resolução dos casos difíceis. Quando os operadores do Direito se deparam com um caso prático, para considerá-lo difícil, devem, em primeiro lugar, verificar se não tem alguma regra que o regule, se não houver, considerando a ideia de tudo-ou-nada, terá de recorrer a outro padrão para resolver a questão. Se resolvê-la com base nos princípios, a solução dada ao caso concreto acaba por estabelecer uma regra jurídica particular ex post facto, embora o princípio em que ela se fundamente seja a ela prévio, por isso não se cria um direito novo, apenas lhe é dado concretude com essa regra. A esse respeito, Dworkin esclarece que:

“Uma vez que tenhamos identificado os princípios jurídicos

\footnotetext{
95 Por exemplo, um autor que é famoso por distinguir princípios e regras e por apresentar método de aplicação dos princípios é Robert Alexy, que desenvolveu a ideia de ponderação dos princípios, considerados como mandados de otimização. ALEXY, Robert. Teoria de los Derechos Fundamentales. Madrid: Centro de Estudios Políticos y Constitucionales, 1993
} 
como tipos particulares de padrões, diferentes das regras jurídicas, subitamente nos damos conta de que estão por toda parte, à nossa volta. Os professores de direito os ensinam, os livros de direito os citam e os historiadores do direito o celebram. Mas eles parecem atuar de maneira mais vigorosa, com toda sua força, nas questões judiciais difíceis (...). Depois que o caso é decidido, podemos dizer que ele ilustra uma regra particular (por exemplo, a regra de que um assassino não pode beneficiar-se do testamento de sua vítima). Mas a regra não existe antes de o caso ser decidido; o tribunal cita princípios para justificar a adoção e a aplicação de uma nova regra"96

Feitas essas considerações sobre as distinções iniciais dos princípios, políticas e regras jurídicas, passa-se a análise da teoria da decisão judicial de Dworkin, que envolve como esses três elementos interagem entre si e em que medida são determinantes para a tomada de decisão judicial coerente com o conceito de Direito como integridade.

\section{II.2. A TEORIA DA DECISÃo JUdiCIAL DE RONALD DWORKIN}

A teoria da decisão judicial de Dworkin faz parte da sua teoria geral do Direito ${ }^{97}$, o que já foi sinalizado, neste trabalho, tendo em vista que o conceito de Direito é um conceito interpretativo ${ }^{98}$. A esse respeito, deve-se esclarecer que há uma importante diferença da teoria proposta por Dworkin em relação aos positivistas analíticos (e.g. Kelsen, Austin etc), os quais visam

\footnotetext{
DWORKIN, Ronald. Levando os direitos a sério, cit., p. 46

DWORKIN, Ronald. O império do direito, cit., pp. 112-113; A justiça de toga, cit., p. 29

98 "Para ele, as práticas jurídicas ocorrem dentro de um contexto e impactam esse contexto. Esse impacto contextual é medido e avaliado em termos morais. Por esse motivo o conceito de direito é um conceito político. É importante salientar que o que o torna político é a existência de uma intencionalidade referida a uma demanda de legitimação moral. (...) O caráter argumentativo e discursivo do direito, aliado ao fato de que em seu interior são produzidas disputas e controvérsias sobre a melhor forma de conceptualizar conceitos, confere ao direito uma natureza essencialmente interpretativa. Em outras palavras, a gramática lógica do jogo jurídico, além de envolver uma prática social normativa, implica também que esta seja interpretativa, e não meramente convencional" MACEDO JUNIOR, Ronaldo Porto. Do xadrez à cortesia: Dworkin e a teoria do direito contemporânea, cit., pp. 157-158
} 
fundar as suas teorias do Direito na ideia da validade, ou seja, focam-se sobre o que pode ser considerado Direito, sem explicar como ele deve ser aplicado (interpretado) após essa identificação ${ }^{99}$. Por essa perspectiva, há uma desvinculação da teoria geral do Direito da teoria da decisão judicial, que ficaria relegada. Dworkin vai no sentido contrário dessa perspectiva ${ }^{100}$. Com relação a este ponto, para que não falte clareza, irão ser refinadas algumas questões da teoria geral do Direito de Dworkin, que irão iluminar a sua teoria da decisão judicial.

No Capítulo II.1., apresentou-se o conceito de Direito para Dworkin, enquanto um conceito interpretativo, todavia, é necessário aprofundar um pouco mais sobre como esse conceito interpretativo é afetado pela moralidade política da comunidade, e se esta moralidade deve ser utilizada como condição de veracidade das proposições jurídicas colocadas em análise por um juiz ao decidir um caso concreto. A necessidade de se verificar a veracidade da proposição, na teoria da decisão judicial de Dworkin, decorre do fato de que os juízes apenas poderiam decidir, com a necessária responsabilidade ao papel que desempenham, se a proposição jurídica escolhida para fundamentar a sua decisão for a resposta correta (esse tema será retomado

99 "Quando se sabe $o$ que deverá ser aplicado (questão de validade), a teoria do direito se limita a um exercício acadêmico sem relevância cognitiva para o aplicador do direito. Isso indica a ausência de uma teoria juspositivista no âmbito da interpretação.” (DIMOULIS, Dimitri. Positivismo jurídico: introdução a uma teoria do direito e defesa do pragmatismo jurídico-político, São Paulo: Método, 2006, p. 218); “También aparece la idea - ciertamente heterodoxa en el campo de la reflexión analítica - de que la teoría jurídica no sólo tiene funciones descriptivo-cognoscitivas sino tambiém prescriptivas. La teoría jurídica fundamenta una tecnologia que sirve para ayudar al juez a resolver los casos difíciles. De tal forma que la distinción entre la parte conceptual y la parte normativa de la ciencia general del derecho tampoco se mantiene de la forma rígida recomendada por las escuelas analíticas.” (CALSAMIGLIA, Albert. ¿Por qué es importante Dworkin?, cit., p. 163)

100 "Para Dworkin, todavia, existe uma continuidade básica e essencial entre questões teórico-jurídicas (ou questões de filosofia do direito) e questões jurídicas mundanas enfrentadas pelos tribunais e pelos operadores do direto em geral. Para ele, “(...) inexiste uma linha firme que divida a teoria do direito (jurisprudence) da decisão judicial (adjudication) ou qualquer outro aspecto da prática jurídica (...) A teoria do direito é parte geral da decisão judicial (adjudication), um prólogo silencioso de toda decisão jurídica."” MACEDO JUNIOR, Ronaldo Porto. Do xadrez à cortesia: Dworkin e a teoria do direito contemporânea, cit., p. 136 
com maior envergadura, no Capítulo II.3.4, sobre a tese da única resposta correta nos casos controversos).

Para conduzir esta questão da moralidade do Direito e sua afetação à teoria da decisão judicial, como fio condutor da veracidade das proposições jurídicas nela utilizadas, Dworkin desenvolve, em sua teoria geral, um conceito de Direito, ao qual denomina doutrinário. Este conceito é formado por aquilo que as pessoas, de uma dada comunidade política, compartilham sobre as exigências, as proibições etc, do Direito em vigor (grosso modo, as normas jurídicas), e abriga, também, as suas consequências práticas ao considerar verdadeiros tais pressupostos compartilhados (genericamente, as consequências/sanções dos direitos e deveres estabelecidos). ${ }^{101}$

A respeito da formulação deste conceito doutrinário de Direito, com intuito de abordar desde o seu aspecto mais germinal (práticas compartilhadas) até a aplicação concreta com a decisão judicial, Dworkin estrutura sua explicação em quatro etapas, que indicam estágios em progressão, aos quais denomina (i) semântico; (ii) teórico; (iii) doutrinário; e (iv) da decisão judicial. Passa-se, a partir de agora, à análise de cada um deles.

No primeiro estágio (semântico), para Dworkin, a questão central a que se procura responder com ele é:

101 “Os estudos desta coletânea tratam sobretudo do direito no sentido que chamarei de doutrinário. Eles exploram o conceito do "direito" de algum lugar ou entidade no sentido de obter determinado efeito: usamos esse conceito doutrinário quando dizemos, por exemplo, que perante o direito de Rhode Island um contrato assinado por alguém com menos de doze anos é nulo ou, o que é ainda mais controverso, que o direito constitucional norte-americano autoriza o presidente a ordenar que estrangeiros suspeitos de atos terroristas sejam submetidos à tortura. Todos nós fazemos afirmações deste tipo sobre aquilo que o direito exige, proíbe, permite ou cria, e compartilhamos muitos pressupostos sobre os tipos de argumentos que são pertinentes à defesa de tais afirmações , e também sobre as consequências que se seguem quando tais afirmações são verdadeiras." DWORKIN, Ronald. A justiça de toga, cit., pp. 4-5 
"quais pressupostos e práticas as pessoas devem compartilhar para que seja sensato dizer que elas compartilham o conceito doutrinário de modo a poderem, claramente, concordar e divergir acerca de sua aplicação?"102

Com intuito de esclarecer esta questão, Dworkin cria uma tipologia própria e divide os conceitos em: (a.) conceitos baseados em critérios; (b.) conceitos de espécies naturais; e (c.) conceitos interpretativos. Nesta última categoria, que se enquadra o conceito doutrinário de Direito. Explicam-se as diferenças dessa tipologia.

(a.) Os conceitos baseados em critérios são formulados a partir da concordância de critérios para que seja possível utilizá-lo de maneira apropriada em um dado contexto. As pessoas, por exemplo, concordam que um quadrado tem quatro lados iguais e este é o critério que usam para conceituar se algo é, ou não, um quadrado. O quadrado é um conceito baseado em critério, que se mostra bastante preciso. Todavia, nem todos os conceitos baseados em critérios têm a mesma precisão. Dworkin, por exemplo, afirma que o casamento pode ser um conceito baseado em critérios e, em algumas ocasiões, mostrar-se inadequado recorrer a esses critérios previamente estabelecidos para resolver uma dada questão prática. Por exemplo, no caso de definir se se "enquadra", ou não, no conceito de casamento, a união homoafetiva. ${ }^{103}$

(b.) Os conceitos de espécies naturais, diferentemente dos conceitos baseados em critérios, são aqueles:

“cujos exemplos têm uma estrutura física ou biológica natural metais e animais, por exemplo -, ainda que não concordem quanto à natureza essencial dos conceitos ou quanto aos

02 DWORKIN, Ronald. A justiça de toga,cit., p. 15

103 DWORKIN, Ronald. A justiça de toga,cit., p. 16 
critérios que utilizam para identificar tais exemplos."104

Nestes casos, o objeto analisado é matéria bruta, e cada pessoa pode considerá-la, de acordo com seu interesse e nível cultural, sob uma perspectiva diferente, mas isso não a descaracteriza. Uma criança no zoológico, certamente, enxerga um elefante de maneira diferente que um geneticista o vê, mas ambos concordam que o animal é um elefante. Sobre estes conceitos, tornase mais clara a possibilidade de descrever e afirmar a veracidade das suas proposições. Por exemplo, todos aqueles que são versados em química concordariam que soda cáustica (hidróxido de sódio - $\mathrm{NaOH}$ ) tem em sua composição sódio, oxigênio e hidrogênio.

(c.) Por último, Dworkin destaca os conceitos interpretativos, que são os mais relevantes à sua teoria geral, na medida em que o conceito doutrinário de Direito, de acordo com este autor, é um conceito interpretativo. Dworkin defende que os conceitos centrais evocados na teoria política e na prática jurídica são interpretativos, como a liberdade, igualdade, Democracia etc. Os operadores do Direito, em geral, concordam que estes conceitos são interpretativos, e compartilham as práticas que o subsidiam e permitem afirmálo enquanto esse tipo de conceito. Todavia, apesar de fundarem-se neste substrato compartilhado, tendem a discordar quanto à sua aplicação em um caso concreto. Nesse sentido, Dworkin esclarece que:

"Os conceitos interpretativos também exigem que as pessoas compartilhem uma prática: elas devem admitir consensualmente que o conceito seja tratado como interpretativo. Mas isso não significa que também devam estar de acordo quanto à aplicação do conceito. As pessoas podem compartilhar tal conceito mesmo quando divergem drasticamente quanto a seus exemplos. Portanto, uma boa teoria de um conceito interpretativo - uma teoria da justiça ou de se

104 DWORKIN, Ronald. A justiça de toga,cit. ,p. 16 
ganhar um assalto em uma luta de boxe - não pode simplesmente descrever os critérios que as pessoas usam para identificar casos ilustrativos ou apenas expor a estrutura profunda daquilo que a maioria entende como exemplos. Uma boa teoria de um conceito interpretativo deve ser, em si mesma, uma interpretação, de caráter provavelmente polêmico, da prática em que está inserido o conceito."

Como se admitiu supra a existência costumeira de divergências para aplicar estes conceitos interpretativos, é necessário estabelecer, na etapa que se segue a este estágio, o que deve orientar a aplicação dos conceitos interpretativos, já que eles não são informados por critérios, nem fundam-se em matéria bruta, mas encontram-se em algo mais difuso, que são as práticas compartilhadas pelos membros daquela comunidade política. Para se decidir um caso com base nestes conceitos interpretativos, ou seja, para aplicá-los na prática com responsabilidade, deve-se considerar o seu valor e propósito na prática jurídica. Se estes valores e propósitos devem orientar a aplicação de um conceito interpretativo, é necessário, portanto, identificá-los, o que é feito, no segundo estágio, o teórico.

O segundo estágio (teórico) tem por objetivo a interpretação da prática jurídica para identificação dos valores do conceito interpretativo elaborado no estágio semântico. De acordo com Dworkin, os conceitos interpretativos, embora sejam valores em si mesmos, dependem que o intérprete o insira em um contexto de outros valores, pluralmente considerados. Nessa empreitada, portanto, o intérprete deve recorrer a um conjunto mais vasto de convicções, como Dworkin esclarece:

“(...) se queremos entender realmente o que é a liberdade, a democracia, o direito ou a justiça, devemos enfrentar a difícil questão de saber como identificar o valor de um valor. Só

105 DWORKIN, Ronald. A justiça de toga,cit. p. 19 
podemos esperar fazê-lo - como afirmarei - se situarmos o lugar do valor em uma rede mais ampla de convicções."

A esse respeito, esclarece-se que, na teoria de Dworkin, há duas formas distintas de interpretar um valor, pode-se entendê-lo como autônomo, ou integrado. Se entendê-lo como autônomo não seria necessário recorrer a uma teia de valores outros que fariam parte daquela prática, não haveria um dever de coerência para com esta, não importando, nesse sentido, as consequências que ele geraria quando aplicado especificamente. Por outro lado, se entendê-lo como um valor integrado, ele careceria estar inserido em uma teia de valores, de modo a considerar as consequências da sua aplicação, havendo um dever de coerência, que dá unidade à teia. ${ }^{107}$

Dworkin rejeita a concepção autônoma dos valores na prática jurídica, ele defende que os valores, neste contexto, são integrados e, portanto, exigem que se considerem as suas consequências quando aplicados. Essas consequências devem proporcionar uma vida boa às pessoas e, se assim o fizerem, também, serão um valor. Há um círculo virtuoso.

Dentro desta visão holística, Dworkin afirma que não há hierarquia entre os valores e sim uma constante interação entre eles, em que cada um contribui a sua forma ao objetivo último de todos, que seria uma boa vida aos membros da comunidade política, que somente é possível se todos forem tratados com igual consideração pelo Direito ${ }^{108}$, regidos por um conjunto

106 DWORKIN, Ronald. A justiça de toga, cit. p. 221

107 "Em primeiro lugar, podemos tratar o valor como algo autônomo em relação a nossa preocupação de viver bem e determinado independentemente dela: devemos respeitá-lo simplesmente porque ele constitui, em si mesmo, algo de valor que, de nossa parte, será um erro ou uma impropriedade não reconhecer. $\mathrm{Ou}$, em segundo lugar, podemos tratar o valor como algo integrado ao nosso interesse em viver bem: podemos pressupor que se trata de um valor, e que tem o caráter que tem, porque o fato de aceitá-lo como um valor dotado de tal caráter enriquece a nossa vida de algum outro modo." DWORKIN, Ronald. A justiça de toga,cit. pp. 221-222

108 "Refiro-me à integridade política, que significa igualdade perante o direito não apenas no sentido que 
de princípios a priori aplicável a todos. Para que se clareie a maneira como os valores integrados são compreendidos por Dworkin, seleciona-se o seguinte trecho de sua obra:

\begin{abstract}
"A filosofia política que pretende compreender melhor os valores políticos deve incorporar seu próprio trabalho nessa grande estrutura. Deve almejar, primeiro, elaborar concepções ou interpretações de cada um desses valores que fortaleçam os outros - por exemplo, uma concepção de democracia que seja útil à igualdade e à liberdade, e concepções de cada um desses outros valores que sejam úteis à democracia assim concebida. (...) Tudo isso, sem dúvida, parece impossivelmente e, talvez, até mesmo desagradavelmente holístico. Mas não vejo de que outra maneira os filósofos podem abordar a tarefa de atribuir o máximo possível de sentido crítico a quaisquer dessa vasta estrutura humana, que dirá dela toda. (...) É mais fácil encontrar um sentido profundo de exatidão em um conjunto de valores unificados e integrados do que em uma lista de compras." 109
\end{abstract}

Em suma, o estágio teórico de Dworkin - que visa à interpretação da prática jurídica para identificação dos valores dos conceitos interpretativos elaborados no estágio semântico - opera com valores integrados, em que se busca o valor do valor de uma posição, ou de outra, considerando-se como melhores àquelas que se mostrarem mais integradas/coerentes com os demais valores.

Esclarecidos os pontos centrais do estágio teórico, passa-se à análise do estágio doutrinário. O estágio doutrinário, na teoria de Dworkin, tem por objetivo descrever as condições de veracidade das proposições de Direito de acordo com os valores identificados no estágio teórico. ${ }^{110} \mathrm{~A}$ identificação da

ele seja imposto conforme escrito, mas no sentido mais pertinente de que o Estado deve governar de acordo com um conjunto de princípios em princípio aplicável a todos.” DWORKIN, Ronald. $A$ justiça de toga,cit., p. 250

109 DWORKIN, Ronald. A justiça de toga, cit., pp. 228-229

110 DWORKIN, Ronald. A justiça de toga,cit., p. 21 
veracidade de uma proposição jurídica é possível diante de um caso prático, ou seja, este processo de verificação não é feito em abstrato. Para Dworkin, uma proposição jurídica é verdadeira se o intérprete, em respeito aos princípios de moralidade, apresentar uma solução que corresponda à melhor justificativa à prática jurídica (passada/presente/futura) de uma dada comunidade política. Pode-se dizer que, neste estágio, passa-se um filtro nos valores identificados no estágio anterior (teórico), para que se possa escolher qual deles apresenta uma resposta que melhor justifique a prática jurídica.

Nesse sentido, as condições de veracidade de uma proposição jurídica, no estágio doutrinário, verificam-se se atenderem aos valores identificados no estágio teórico, os quais devem representar a melhor justificação daquela proposição contextualizada na prática jurídica da comunidade $^{111}$. Com relação ao sucesso de uma justificação, Dworkin afirma que a proposta deve adequar-se àquilo que pretende justificar, isto é, não deve evocar o que sabe não ser parte da prática jurídica, como por exemplo, afirmar que a prática serve para cumprir os desígnios de Deus escritos na Bíblia. Além disso, Dworkin afirma que a justificação, também, deve observar os valores relevantes a esta prática:

"Em primeiro lugar, uma justificação deve, ao menos grosso modo, adequar-se àquilo que pretende justificar: para a prática jurídica contemporânea, não seria uma justificação competente afirmar que ela se presta à aplicação de um desígnio divino tal como revelado em um documento bíblico. Ainda que isso fosse um objetivo legítimo e importante a ser adotado pela prática jurídica, não podemos afirmar que se trata do objetivo de nossa prática jurídica, uma vez que tal afirmação não corresponderia minimamente à verdadeira atividade de juristas e juízes. Em segundo lugar, a justificação de uma prática deve ir além de simplesmente ajustar-se mais ou menos a ela; deve também descrever algum valor suficientemente importante servido pela

111 DWORKIN, Ronald . A justiça de toga, cit., p. 22 
prática. A afirmação de que essas práticas oferecem uma vida excelente a muitos juristas não justificaria as instituições e as práticas do direito. (...) as duas dimensões - a de ajuste e a de valor - representam aspectos diferentes de uma mesma avaliação geral da moralidade política, e o modo como aplicarmos e unirmos os dois critérios em uma avaliação final do êxito interpretativo no estágio doutrinário irá refletir a avaliação que tivermos feito no estágio teórico anterior."

A partir dessas considerações, resta clara a relação de interconexão entre os estágios, a partir dos pressupostos que se firmam em um, prossegue-se ao seguinte. Há uma progressão de estágios, cujas respostas podem ser iguais, ou diferentes, de acordo com o que o intérprete estabelece no estágio anterior. Esse caminho percorrido entre os diferentes estágios será essencial para análise do último estágio, o estágio da decisão judicial, cuja análise mais interessa a este Capítulo.

O estágio da decisão judicial tem por objetivo esclarecer a relação entre a moral e as leis (decisões políticas tomadas, no passado, pelas instituições competentes) no processo decisório judicial. A questão que se coloca é se o juiz pode afastar a aplicação de uma dada lei, em um caso concreto, por uma exigência moral. Dworkin, ao contrário do que muitos acreditam, valoriza as leis, todavia, não considera a sua obediência (supremacia legislativa) como um valor absoluto que sempre deve ser observado pelos juízes e demais operadores do Direito:

"Podemos admitir que, em determinadas ocasiões excepcionais, os juízes devem repudiar ou ignorar a lei naquilo que fazem, mas devemos contar com uma expectativa permanente de que não agirão desse modo, de que decidirão de acordo com o que consideram que as proposições verdadeiras de direito exigem ou permitem." 113

12 DWORKIN, Ronald . A justiça de toga, cit., pp. 23-24

13 DWORKIN, Ronald . A justiça de toga,cit., p. 29 
A legalidade (supremacia legislativa), enquanto um valor integrado, deve ser concebida em conjunto com os demais valores importantes à prática jurídica, em respeito à integridade. Não se pode afirmar a veracidade de uma proposição jurídica, conforme explanado no estágio doutrinário, se não forem considerados os princípios de moralidade que ofereçam a melhor interpretação da proposição colocada em análise. ${ }^{114}$

O conceito de Direito para Dworkin, por ser interpretativo, conforme estabelecido no estágio semântico, não se limita ao que está escrito na lei, pode ir além dela, e em alguns casos até suprimi-la, quando sua aplicação não atender aos valores identificados no estágio teórico. Por essa razão, Dworkin defende que o Direito não se presta a ser uma descrição neutra da prática jurídica, ou do conteúdo das leis, mas deve ser norteado por valores que melhor justificam essa prática complexa (composta por elementos históricos, normativos, morais etc.). A interferência da moral na decisão judicial decorre, neste contexto metodológico apresentado, do fato dela fazer parte da prática jurídica, conforme identificado no estágio semântico, pois o Direito, enquanto conceito interpretativo, não se confunde com a lei, é muito mais complexo que ela. $^{115}$

Por último, como fechamento dos quatro estágios explanados, destaca-se que o valor da integridade (coerência na prática jurídica segundo a qual todos devem ser tratados por princípios aplicáveis a priori a todos), tão

114 DWORKIN, Ronald . A justiça de toga,cit. ,p. 250

${ }^{115}$ Esclarece-se que, neste trecho, a expressão Law significa Direito: "Interpretativism, on the other hand, denies that law and morals are wholly independent systems. It argues that law includes not only the specific rules enacted in accordance with the community's accepted practices but also the principles that provide the best moral justification for those enacted rules. The law then also includes rules that follow from those justifying principles, even though those further rules were never enacted. Interpretativism, in other words, treats legal reasoning as I have argued in this book we must treat all interpretative reasoning. It treats the concept of law as an interpretative concept." DWORKIN, Ronald. Justice for hedgehogs, cit., p. 402 
caro à teoria de Dworkin para a conceituação do Direito, não exerce seu papel apenas no estágio semântico e teórico, ele vai além, influenciando o estágio da decisão judicial, na medida em que exige a consideração à moral, especialmente, nos casos difíceis, em que a lei positivada não se mostra suficiente, para que se possa estabelecer o que é o Direito e como os juízes devem desempenhar o seu papel com responsabilidade ao julgar tais casos com respeito à integridade.

Feitas essas considerações metodológicas sobre a teoria do direito e teoria da decisão judicial, e sua relação com a moralidade, aprofunda-se a teoria da decisão judicial, por um viés mais prático, com a análise de como interagem regras, princípios e políticas, na construção da decisão judicial, especialmente no que se refere aos casos difíceis.

Sobre esta temática, a primeira questão que se coloca é se os juízes ao julgarem um caso difícil, o qual por sua natureza não tem um normativo (lei, costume, precedentes) claro que o regule, poderiam criar um direito novo, como os legisladores, que são políticos eleitos, fazem. Para Dworkin, os juízes não assumem este papel de legisladores delegados, mas isso não significa que eles não estão indo além das decisões políticas passadas ${ }^{116}$ :

"Os juízes não deveriam ser e não são legisladores delegados, e é enganoso o conhecido pressuposto de que eles estão legislando quando vão além de decisões políticas já tomadas por outras pessoas. Este pressuposto não leva em consideração a importância de uma distinção fundamental na teoria política que agora introduzirei de modo sumário. Refiro-me à distinção entre argumentos de princípio, por um lado, e argumentos de política (policy), por outro."

${ }^{116}$ Esclarece-se que não se adentrará neste Capítulo, na questão da violação da Democracia, quando os juízes não decidem seus casos com base em uma decisão política passada tomada pelos políticos eleitos. Este tema será objeto de discussão no Capítulo III.3. desta dissertação.

117 DWORKIN, Ronald. Levando os direitos a sério,cit., p. 129 
Como mencionado no excerto selecionado, o erro daqueles que fazem a afirmação de que os juízes legislam consiste em não considerar a diferença entre argumentos de política e argumentos de princípio. Os argumentos de política dizem respeito a objetivos coletivos, considerando a comunidade em sua totalidade, enquanto os argumentos de princípios dizem respeito a direitos individuais, ou de um grupo.

Os casos fáceis, em que há uma norma clara aplicável, não geram controvérsia quanto ao argumento que deve ser utilizado para decidi-lo, no caso, o argumento de princípio; todavia, nas questões difíceis, essa opção não é tão óbvia.

A esse respeito, Dworkin menciona o caso Spartan Steel \& Alloys Ltd. vs. Martin \& Co., segundo o qual:

"Os empregados do réu haviam rompido um cabo elétrico pertencente a uma companhia de energia elétrica que fornecia energia ao autor da ação, e a fábrica deste foi fechada enquanto o cabo estava sendo consertado. $\mathrm{O}$ tribunal tinha de decidir se permitiria ou não que o demandante fosse indenizado por perda econômica decorrente de danos à propriedade alheia cometidos por negligência."

Diante deste caso, para Dworkin, os juízes teriam duas opções: (i) se fossem utilizar argumentos de princípio perguntariam se o autor tem direito à indenização pleiteada; e (ii) se fossem utilizar argumentos de política, considerando a comunidade como um todo, questionariam economicamente qual seria a alternativa mais adequada para as duas empresas litigantes, considerando eventual repartição dos prejuízos entre ambas.

${ }^{118}$ DWORKIN, Ronald. Levando os direitos a sério,cit., p. 131 
Dworkin defende que não se deve decidir casos difíceis, como o acima referido, com base em argumentos de política, mas em argumentos de princípio. Caso os juízes decidissem com base em argumentos de política poderse-ia dizer que são legisladores delegados, o que não é o papel dos juízes na teoria da decisão judicial proposta por Dworkin.

Considerando esta afirmação, que os juízes devem decidir com base em argumentos de princípios, isto é, com base no Direito, a questão que resta pendente é como se dá a relação entre originalidade judicial (que é inerente à resolução dos casos difíceis) e a história institucional (decisões políticas tomadas pelas instituições competentes). Dworkin afirma que os direitos existentes de um cidadão são estabelecidos tanto pelas instituições políticas (como a Câmara dos Deputados, Senado, Presidente da República), como são, também, decorrentes da moralidade política da comunidade e, desse modo, podem ser reconhecidos pelos juízes mesmo não tendo sido, previamente, estabelecidos pelas referidas instituições políticas:

"Os direitos políticos são criações tanto da história, quanto da moralidade: aquilo a que um indivíduo tem direito, na sociedade civil, depende tanto da prática quanto da justiça de suas instituições políticas. Desse modo, desaparece a alegada tensão entre originalidade judicial e história institucional $(\ldots)^{\prime \prime 119}$

A liberdade do juiz, certamente, é mais restrita que a do legislador na teoria apresentada por Dworkin, na medida em que ele apenas reconhece aquilo que já foi posto pela moralidade da comunidade política, ainda que não esteja institucionalmente reconhecido, e, além disso, tem o dever de coerência. Ao contrário dos legisladores, que podem criar realmente um direito novo de

119 DWORKIN, Ronald. Levando os direitos a sério,cit., p. 136 
maneira mais livre, beneficiando um determinado grupo com uma lei, e prejudicando um outro setor econômico, conforme a conveniência política the indicar. Os juízes, ao contrário, não devem seguir conveniências, pois são norteados por argumentos de princípio, e têm a partir disso um dever de coerência, de aplicar o Direito pertinente a todos os membros da comunidade política, da maneira mais igualitária possível, sem criar favorecimentos a uma determinada classe sem que haja um Direito que os justifique ${ }^{120}$. Os políticos, por não encontrarem essa restrição, podem estabelecer, por exemplo, um subsídio a um determinado produto para torná-lo mais competitivo no mercado externo. Um produtor, nas mesmas condições daquele que cultiva o produto subsidiado, de um produto não tão atrativo ao mercado externo, não se beneficiará do referido subsídio e poderá ser prejudicado pela medida. Isto é uma decisão possível para um político, nunca para um juiz na teoria da decisão judicial de Dworkin.

O Capítulo que se segue a este tem por objetivo esclarecer com maior precisão como se opera a aplicação destes princípios e a questão da moralidade política no processo interpretativo que conduz à decisão nos casos difíceis.

\section{II.3. A DECISÃO NOS CASOS DIFÍCEIS}

O desenvolvimento da teoria sobre os hard cases (casos difíceis), na obra de Dworkin, teve início com a publicação de $O$ Modelo de Regras ${ }^{121}$, em 1967, e, posteriormente, com artigo do autor publicado na Harvard Law Review $^{122}$, cujo nome é Hard Cases, em 1975, prosseguiu-se o aprofundamento

\footnotetext{
${ }^{120}$ DWORKIN, Ronald. Levando os direitos a sério, cit., p. 138

121 DWORKIN, Ronald. The model of rules, University of Chicago Law Review, vol. 35, 1967, pp. 1446

122 DWORKIN, Ronald. Hard cases, Harvard Law Review, vol. 88, abril, 1975, pp. 1057-1109
} 
de sua análise, tratando, com maior especificidade, o estudo destes $\operatorname{casos}^{123}$. A esse respeito, destaca-se que a preocupação com os hard cases, em si, não é inovadora, ao revés, é bastante antiga, por exemplo, já estava presente na obra de Gottfried Wilhelm von Leibniz, com a sua tese de doutoramento Disputatio Inauguralis de Casibus Perplexibus in Jure, apresentada em $1666^{124}$. Todavia, pode-se dizer que a inovação das teorias sobre essa temática acaba residindo na forma como se conceitua os casos difíceis e nas propostas apresentadas para resolvê-los, as quais variam conforme o conceito de Direito de cada tempo e cultura e, também, a ideologia adotada pelo doutrinador.

Os casos difíceis, na teoria formulada por Dworkin, que é objeto deste trabalho, podem ser conceituados como aqueles em que não há uma norma clara, ou em que não há, efetivamente, qualquer norma (lacuna) a ele aplicável. Entendam-se como norma, neste contexto, as leis e os precedentes. Ou seja, o juiz não tem elementos normativos suficientes que indiquem, preliminarmente, a decisão que deve tomar:

\begin{abstract}
"Os casos difíceis se apresentam, para qualquer juiz, quando sua análise preliminar não fizer prevalecer uma entre duas ou mais interpretações de uma lei ou de um julgado."
\end{abstract}

123 A análise dos casos difíceis aparece em quase todas as obras do autor com maior, ou menor destaque. Por exemplo, em 1978, publicou artigo sobre o mesmo tema (No right answer?, New York University Law Review, vol. 53, n. ${ }^{\circ}$ 1, abril, 1978), o qual, atualmente, encontra-se no Capítulo 5, do livro Uma questão de princípio. Em sua obra mais recente, Justice for hedgehogs, publicada em 2011, também, é tratada a questão da resposta certa nos casos difíceis.

124 "In the last of his formal disputations, which granted him the doctoral degree in November 1666, the Disputatio Inauguralis de Casibus Perplexis in Jure (A VI 1 233-256), Leibniz addresses one of the most difficult issue in legal theory and practice, the so-called "hard cases". (...) Leibniz adopts a rather strict position, according to which "all the cases can be decided by the law alone"." (DASCAL, Marcelo. Leibniz's two-pronged dialetic, In: DASCAL, Marcelo (ed.), Leibniz: what kind of rationalist?, Logic, espistemologic, and the unity of science, vol. 13, Springer, 2008, p. 47) Esclarece-se que por "lei", LEIBNIZ entende que se trata da lei natural, racional, da qual a lei positiva extrai o seu conteúdo, e sobre ela prevalece, conforme é esclarecido na nota de rodapé 43, da obra citada nesta nota: "Quod si jam interpretatio incerta est, adhibendae regulae interpretandi rationis naturalis, et etsi pro utraque parte aequales regulae et praesumptiones militant, judicandum contra eum, qui se in lege aliqua positive, quam tamen introductam satis probare non potest, fundat." (DASCAL, Marcelo. Leibniz's two-pronged dialetic, cit., p. 66)

125 DWORKIN, Ronald. O império do direito, cit. p. 306 
“(...) quando juristas competentes se dividem quanto qual a decisão se exige, porque as únicas leis ou precedentes pertinentes são ambíguos ou não há nenhuma opinião firmada com pertinência direta, ou porque o direito, por alguma razão, não está assente."126

\section{Stephen Guest ${ }^{127}$, ao esclarecer o pensamento de Dworkin,}

\section{conceitua os casos difíceis como:}

“(...) aqueles em que a lei não fornece uma resposta definitiva, o juiz não pode apelar às regras porque, por hipótese, não há regras. Ao invés disso, ele deve recorrer a padrões de $\underset{128}{\arg u m e n t o}$ legal aos quais Dworkin denomina princípios (...)."

A partir desse impasse de não haver regras aplicáveis ao caso, ou o

fato delas não serem claras e, portanto, não indicarem um caminho prima facie ao julgador, considerando a obrigação que todo o juiz tem de decidir os casos judicializados $^{129}$ (princípio da proibição do non liquet), Dworkin desenvolve sua

126 DWORKIN, Ronald. Uma questão de princípio, cit., p. 109

127 Esclarece-se que há outros autores, além de STEPHEN GUEST, que conceituam os casos difíceis na teoria de Dworkin, por exemplo, AULIS AARNIO: "Dworkin starts from a case which he calls, in accordance with traditional terminology, a "hard case". Such a case is typified by the fact that not one provision gives a clear answer to it, the intention of the law cannot recognized, and court precedents as well as other interpretative material point in different direction ("pull both ways")." AARNIO, Aulis. The rational as reasonable, Dordrecht: D. Reidel Publishing Company, 1987, p. 162

128 Tradução livre do seguinte trecho: "In hard cases, which are those where the existing legal practices do not supply a definitive answer, the judge cannot rely on rules because, by hypothesis, there are no rules. Instead, he must rely on standards of legal argument which Dworkin calls principles (...)" GUEST, Stephen. Ronald Dworkin, cit., p. 20

129 Com relação aos casos difíceis, LON L. FULLER, em artigo publicado em 1958, compara a dificuldade do juiz em decidir um caso difícil a de um bibliotecário, que não sabe como classificar certa obra, porque ela não se enquadra em nenhuma das classificações, previamente, estabelecidas. $\mathrm{O}$ bibliotecário não pode descartar o livro, assim como o juiz, não poderia simplesmente não resolver o caso, o desafio que se impõe é saber como isso deve ser feito. "A judge faced with a novel situation is like a library clerk who has to decide where to shelve a new book. There are easy cases: the Bible belongs under Religion, The Wealth of Nations under Economics, etc. Then there are hard cases, when the librarian has to exercise a kind of creative choice, as in deciding whether Das Kapital belongs under Politics or Economics, Gulliver's Travels under Fantasy or Philosophy. But whether the decision where to shelve is easy or hard, once it is made all the librarian has to do is to put the book away. " FULLER, Lon L. Positivism and Fidelity to Law: A Reply to Professor Hart. Harvard Law Review, vol. 71, nº. 4, Feb., 1958, p. 666 
teoria da decisão judicial. A teoria da decisão judicial de Dworkin, como já esclarecido no Capítulo supra (Capítulo II.2. A teoria da decisão judicial de Ronald Dworkin), não se aplica somente aos casos difíceis, decorre de algo mais abrangente que é a teoria geral do direito, cujos conceitos desenvolvidos aplicam-se a tudo que é de Direito, inclusive, aos casos fáceis, com a diferença de que, para estes, não se precisaria fazer perguntas, porque já se saberia as $\operatorname{respostas}^{130}$. No mesmo sentido, o professor Juliano Maranhão, em sua tese de livre-docência, esclarece que a interpretação mostra-se relevante quando não há clareza no objeto a ser interpretado, como, por exemplo, nos casos considerados difíceis, em que as respostas não são obtidas prima facie. ${ }^{131}$

É possível afirmar que o que se desenvolveu na teoria de Dworkin, principalmente, quanto à interpretação judicial, mostra-se mais relevante nos casos difíceis, os quais, por sua natural condição, exigem um esforço teórico maior por parte dos jurisfilósofos para apresentar e justificar suas posições. ${ }^{132}$

130 “O direito como integridade explica e justifica tanto os casos fáceis quanto os difíceis; também mostra porque são fáceis. É evidente que o limite de velocidade na Califórnia é de 90 quilômetros por hora, pois é óbvio que qualquer interpretação competente do código de trânsito desse Estado leva a essa conclusão. (...) a reclamação do crítico é apenas aquilo que o próprio Hércules se daria por satisfeito em reconhecer: que não precisamos fazer perguntas quando já conhecemos as respostas." (g.n.) DWORKIN, Ronald. O império do direito, cit. p. 317

131 "Marmor descreve tais situações como aquelas nas quais o sentido dos termos da norma são claros e dispensam a interpretação para sua aplicação. A interpretação só é chamada a atuar quando a formulação da regra criar dúvida. Trata-se da posição clássica sobre a interpretação,expressa pelo brocardo clara non sunt interpretanda, que pode já ser encontrada, por exemplo, em Leibniz, para quem a clareza é uma qualidade do significado das palavras da lei e está presente quando a apreendemos de forma imediata." MARANHÃO, Juliano Souza de Albuquerque. Positivismo Jurídico Lógico-inclusivo. Tese de livre-docência em Filosofia e Teoria Geral do Direito, Universidade de São Paulo, 2010, p. 109

132 LAWRENCE SOLUM critica a teoria de Dworkin, afirma que, em cada uma de suas obras, ele vai ampliando o escopo da sua teoria interpretativa, pois, (i) em um primeiro momento, na sua obra Levando os direitos a sério, considerou que a sua teoria da interpretação se aplicaria aos casos difíceis, desenvolvendo as dimensões da adequação e justificação para resolver estes casos, depois, (ii) em um segundo momento, na obra $O$ império do direito, estendeu a interpretação a tudo que é relativo ao Direito, inclusive, portanto, aos casos fáceis, e, finalmente, (iii) em um terceiro momento, na sua obra Justice for Hedgehogs, estendeu a sua teoria da interpretação a todos os empreendimentos humanos com a exceção da ciência. Inclusive, Solum comete a deselegância de afirmar que, na próxima obra de Dworkin, se for seguido o mesmo padrão, a teoria da interpretação de Dworkin abarcará todos os domínios do conhecimento, inclusive a ciência: "At this point, however, we are in a position to take stock of the development of Dworkin's theory of interpretation. 
Os casos podem ser considerados difíceis não apenas quando não há lei, ou precedente, ou seja, quando há uma lacuna nestas fontes institucionais, mas também quando estas se apresentam de maneira não clara, de modo a gerar dúvidas no intérprete quanto à sua aplicação. Por exemplo, quando são usados termos vagos em seu texto, como "a indenização será arbitrada de maneira equitativa entre os causadores do dano", sem esclarecer o que se considera equitativo. Poder-se-ia entender que o comando legal indica que cada um arcará de maneira absolutamente igual, ainda que um deles tenha tido uma participação menor no evento danoso. Poder-se-ia entender, por outro lado, que cada um arcará de acordo com sua participação no evento danoso. Poder-se-ia, também, considerar que equitativo, de acordo com o dispositivo legal, exigiria que cada um dos réus arcasse de acordo com o seu poder econômico, independentemente da extensão do dano que cada um deles efetivamente causou ao autor. A partir disso, pode-se observar que há diversas formas de se interpretar o termo equitativo, quando a lei por si não esclarece o que quer dizer com ele e não há consenso sobre o que ele significa. Nestes casos, embora haja uma lei a regular o caso, a abstração do termo utilizado, e falta de consenso sobre o seu significado, dificultaria saber como aplicá-lo ao caso concreto, sendo assim mais uma das formas de se caracterizar um caso como difícil.

Para Dworkin, a abstração, a ambiguidade, ou a obscuridade de

In Hard Cases, interpretivism plays a role limited to the zone that Hart might have called the penumbra of legal rules. In Law's Empire, interpretivism governs all of law. And in Hedgehogs, interpretivism provides the normative theory for all human endeavors except science. If this pattern continues, we might expect that Dworkin's next book will take up the philosophy of science, extending interpretivism to this final domain." (SOLUM, Lawrence B. The unity of interpretation, cit., p. 558) Observa-se que essa crítica de Solum parece não ter respaldo em uma análise mais acurada da obra de Dworkin, na medida em que, de fato, há um refinamento da sua teoria interpretativa, ao longo de suas obras, mas não há contradição neste processo. É natural que um filósofo, quando se propõe a escrever sobre um tema, com o passar do tempo, irá prosseguir no refinamento do seu pensamento, e este processo não implica em uma contradição automática, como parece querer propor Solum. 
uma lei, por si sós, não tornam o caso difícil. O que o assim caracteriza é a dúvida dos intérpretes quanto à maneira correta de aplicá-la. Instaura-se uma divergência em razão dessa abstração, ambiguidade, ou obscuridade. A partir disso, pode-se afirmar que há uma dinamicidade entre casos fáceis e difíceis, isto é, uma lei pode ser clara hoje aos intérpretes e, após algum tempo, a mesma lei deixar de ter a mesma clareza antes vista. Antes o caso seria fácil, depois passou a ser difícil. Nesse sentido, Dworkin esclarece que:

\begin{abstract}
"Quando não houve dúvida, a lei é clara, não porque Hércules tenha alguma forma, fora de seu método geral, de distinguir entre os usos claro e obscuro de uma palavra, mas porque o método que ele sempre utiliza é de tão fácil aplicação que se aplica por si próprio. (...) É "óbvio" que o limite de velocidade em Connecticut é de 88 quilômetros por hora, e que os ingleses devem pagar pela comida que pedem em um restaurante. A não ser em circunstâncias muito incomuns, isso é realmente óbvio. (...) Incluímos entre os casos fáceis a questão de saber se, legalmente, alguém pode dirigir mais rápido que o limite de velocidade estipulado porque admitimos de imediato que nenhuma análise dos documentos jurídicos que negasse esse paradigma seria adequada. Contudo, uma pessoa cujas convicções sobre justiça e equidade fossem muito diferentes das nossas poderia não achar essa pergunta fácil; mesmo que terminasse por concordar com nossa resposta, insistiria em dizer que estávamos errados por ser tão confiantes. Isso explica por que questões consideradas fáceis durante certo período tornam-se difíceis antes de se tornarem novamente fáceis - com as respostas opostas." 133
\end{abstract}

Em prosseguimento, feita a conceituação de casos difíceis para Dworkin, dá-se o próximo passo e o mais relevante deles: a análise da teoria de Dworkin na construção do processo decisório dos casos difíceis. Esse processo será divido em quatro frentes centrais neste trabalho, quais sejam, (i) as etapas da interpretação e o método de Hércules; (ii) o poder discricionário dos juízes; (iii) direitos institucionais e jurídicos; e, por fim, (iv) a tese da única resposta

133 DWORKIN, Ronald. O império do direito, cit. pp. 422-424 
certa nos casos controversos, com especial atenção à crítica dos céticos.

Após percorrer estas quatro frentes, detalhando as questões a elas pertinentes, restará concluída, ao final deste Capítulo, a construção do processo decisório dos casos difíceis na teoria de Ronald Dworkin.

\section{II.3.1. ETAPAS DA INTERPRETAÇÃO E O MÉTODO DE HÉRCULES}

As etapas da interpretação ${ }^{134}$, que serão aqui apresentadas, refletem em alguma medida, aquilo que se refinou no Capítulo II.2., sobre a teoria da decisão judicial. De maneira didática, Dworkin divide em três fases distintas as etapas da interpretação. A primeira fase consiste na fase préinterpretativa; a segunda, na fase interpretativa; e a terceira, na fase pósinterpretativa. Passa-se, em um primeiro momento, a analisar em que consiste cada uma delas como uma introdução conceitual necessária, inclusive, ao método de Hércules, sobre o qual se falará mais adiante.

Na primeira fase (pré-interpretativa), identifica-se aquilo que há de consenso na comunidade política. Essa fase, ainda que se denomine préinterpretativa, também, envolve certa interpretação ainda que mínima de acordo com Dworkin. Procura-se encontrar as bases comuns, os padrões com que todos concordam, isto é, visa-se encontrar o consenso, para então poder caminhar à fase seguinte e as pessoas se entenderem minimamente quando dialogam. Não é possível iniciar um verdadeiro diálogo com alguém, em que são genuínas as divergências interpretativas, quando não há consenso mínimo para alguns

\footnotetext{
134 "We interpret social practices, first, when we individuate those practices: when we take ourselves to be engaged in legal rather than literary interpretation. We interpret, second, when we attribute some package of purposes to the genre or subgenre we identify as pertinent, and, third, when we try to identify the best realization of that package of purposes on some particular occasion." DWORKIN, Ronald. Justice for hedgehogs, cit., p. 131
} 
aspectos e características da prática sob análise. A esse respeito Dworkin esclarece que:

"O direito não pode florescer como um empreendimento interpretativo em qualquer comunidade, a menos que haja suficiente consenso inicial sobre quais práticas são práticas jurídicas, de tal modo que os advogados discutam sobre a melhor interpretação a ser aplicada, grosso modo, aos mesmos dados. Essa é uma exigência prática de qualquer empreendimento interpretativo: seria inútil que dois críticos discutissem sobre a melhor interpretação de um poema se um deles tivesse em mente o poema Sailing to Byzanthium e o outro estivesse pensando em Mathilda Who Told Lies. Não quero dizer que todos os advogados, sempre e em todos os lugares, devam estar de acordo sobre exatamente quais matérias devem considerar como matérias jurídicas, mas apenas que os advogados de qualquer cultura na qual a atitude interpretativa seja bem-sucedida devem, em grande parte, estar de acordo em qualquer época dada. Todos entramos na história de uma prática interpretativa em um determinado momento; nesse sentido, o necessário acordo pré-interpretativo é contingente e local" 135

Na segunda fase (interpretativa), o intérprete irá estabelecer qual a melhor justificativa geral aos elementos da prática jurídica sobre os quais se encontrou consenso na fase anterior. Essa justificação não precisa ser absolutamente convergente com todos os elementos da prática jurídica, até porque nem tudo sobre o que há consenso, quando analisado em conjunto, produz um resultado interpretativo uníssono. Dworkin destaca que a interpretação realizada nesta etapa, todavia, precisa ser fruto genuíno daquilo que se coletou enquanto característica e aspecto da prática jurídica na fase préinterpretativa e não uma mera criação de algo novo. ${ }^{136}$

135 DWORKIN, Ronald. O império do direito,cit. p. 113

136 “A justificativa não precisa ajustar-se a todos os aspectos ou características da prática estabelecida, mas deve ajustar-se o suficiente para que o intérprete possa ver-se como alguém que interpreta essa prática, não como alguém que inventa uma nova prática." DWORKIN, Ronald. $O$ império do direito,cit. p. 81 
$\mathrm{Na}$ terceira fase (pós-interpretativa) ${ }^{137}$, o intérprete deve dar concretude às normas de acordo com as exigências que a prática requer em consideração à justificativa geral da prática jurídica estabelecida na fase interpretativa. É uma questão de ver a prática sob sua melhor luz, isto é, o intérprete deve definir que tipo de decisão concreta melhor atende à justificativa estabelecida na fase anterior. Há uma reformulação daquilo que se mostra inadequado na prática para que se atenda da melhor maneira possível à justificativa encontrada na etapa interpretativa. Essa fase apresenta o elemento mais dinâmico na interpretação, pois não exige consenso quanto ao que seria a decisão sob sua melhor luz, apenas que se observe à justificativa aceita na etapa interpretativa. A divergência ocorre em razão de se entender que a justificativa será mais bem alcançada de uma maneira e não de outra a partir de um mesmo contexto fático e normativo. Nesse sentido, Dworkin exemplifica que:

"Um intérprete da comunidade hipotética em que se pratica a cortesia, por exemplo, pode vir a pensar que uma aplicação coerente da melhor justificativa dessa prática exigiria que as pessoas tirassem os chapéus tanto para soldados que voltam de uma guerra quanto para os nobres. Ou que ela exige uma nova exceção a um padrão estabelecido de deferência: isentar os soldados das demonstrações de cortesia quando voltam da guerra, por exemplo. Ou, talvez, até mesmo que uma regra

137 ANDREI MARMOR comenta sobre a diferença entre a fase interpretativa (segunda fase) e a fase pósinterpretativa (terceira fase): "Now, returning to fit, it seems (though Dworkin is not explicit on this point) that the main difference between the interpretative and the post-interpretative stages is as follows: in the former, fit is basically a threshold requirement. The proposed interpretation 'must fit enough for the interpreter to be able to see himself as interpreting that practice, not inventing one'(1986: 66, emphasis mine). But this may not be enough, as several and conflicting interpretations may fit the text in this sense. The post-interpretative stage introduces another, more evaluative notion of fit. It involves the choice of that interpretation which is attributed the better, or actually, the best fit. In other words, when fit operates as threshold requirement, it is more likely a necessary condition; the interpretation must account for enough parts of the text and must consider paradigm cases as such (with the proviso mentioned earlier). A interpretation of a novel requiring us to disregard every second line in the book, or a legal theory claiming that statutes are not part of the law of England are easy examples of unfitness in this sense. Fit in the post-interpretative stage is more substantially evaluative. At the very least, it seems to assume that the more fit, the better. At this stage, the intepreter 'adjusts his sense of what the practice "really" requires so as better to serve the justification he accepts at the interpretative stage'." MARMOR, Andrei. Interpretation and legal theory, cit., p. 55 
inteira estipulando deferência para com todo um grupo (ou toda uma classe) de pessoas deva ser vista como um erro à luz daquela justificativa." 138

Embora, Dworkin estabeleça essa maneira estruturada das etapas da interpretação, ele afirma que os juízos interpretativos, em geral, ocorrem de maneira não segmentada por etapas, é um processo automático para as pessoas.

Feitas essas considerações sobre as etapas da interpretação, passase a segunda parte deste Capítulo, que é a análise do método de Hércules, o qual ilustra a maneira como se deve construir uma decisão judicial de um caso difícil, isto é, o que deve ser considerado pelos juízes ao decidir um caso e como esses elementos a ser considerados interagem entre si e são determinantes para o resultado final ${ }^{139}$. Em primeiro lugar, é importante esclarecer quem seria Hércules nesta teoria. Hércules seria um juiz muito especial, pois seria dotado de "capacidade, sabedoria, paciência e sagacidade sobre-humanas" "140.

No seu processo interpretativo/decisório, Hércules deve ser norteado pela prática jurídica de sua comunidade e, portanto, deve considerar tudo a ela pertinente: a Constituição e as leis infraconstitucionais, enquanto elementos legislativos; os precedentes, enquanto direito costumeiro (common law); bem como a moralidade política, enquanto elemento moral de seu juízo.

Com relação à Constituição, no método de Hércules, ela teria o papel de fornecer os princípios e políticas que justificam o sistema de

138 DWORKIN, Ronald. O império do direito, cit., p. 82

139 HABERMAS, ao comentar sobre o juiz Hércules de Dworkin, afirma os componentes do saber deste juiz: "O "juiz Hércules" dispõe de dois componentes de um saber ideal: ele conhece todos os princípios e objetivos válidos que são necessários para a justificação; ao mesmo tempo, ele tem uma visão completa sobre o tecido cerrado dos elementos do direito vigente que ele encontra diante de si, ligados através de fios argumentativos. Ambos os componentes traçam limites à construção de sua teoria." HABERMAS, Jürgen. Direito e democracia: entre facticidade e validade, cit., p. 263

140 DWORKIN, Ronald. O império do direito, cit., p. 165 
governo $^{141}$. Nesse contexto, ao se deparar com casos difíceis, Hércules deve analisar a Constituição como um todo, enquanto este conjunto complexo de princípios e políticas, e testar se sua decisão se harmoniza da melhor maneira possível a ela. As leis, por sua vez, oferecem um limite a essas possíveis harmonizações, uma vez que a linguagem empregada pelo legislador limita a gama de interpretações possíveis ao juiz. Nesse ponto, remete-se a ideia já explanada no Capítulo II.1. O Conceito de Direito para Ronald Dworkin, no qual se referiu ao romance em cadeia e a necessidade de se manter o respeito às dimensões de adequação e justificação, no processo interpretativo de construção do Direito como integridade. Hércules é parte dessa ideia de romance em cadeia, um complemento alegórico dela, e não o oferecimento de uma nova perspectiva. Nesse sentido, rememora-se a importante ideia de que o respeito aos limites da linguagem empregada pelo legislador não é o mesmo que observar suas intenções concretas com tal dispositivo (corrente dos originalistas/intencionalistas). Em outras palavras, os objetivos concretos do dispositivo legal positivado pelo legislador não é um limite a Hércules; o limite encontra-se na linguagem por ele empregada:

"Os termos da lei efetivamente promulgada pelo poder
legislativo permitem que este processo de interpretação opere
sem incorrer em qualquer absurdo; permitem que Hércules
afirme que o poder legislativo estendeu uma política até os
limites permitidos pela linguagem de que fez uso. No entanto,
Hércules não supõe que o poder legislativo tenha estendido essa
política até um ponto ulterior indeterminado, além desse
limite."142

Nesse sentindo, pode-se afirmar que Hércules não deve, em seu processo interpretativo, extrapolar os limites da linguagem empregada pelos legisladores, extraindo dela um conteúdo que não é possível alcançar.

141 DWORKIN, Ronald. O império do direito, cit., p. 167

142 DWORKIN, Ronald. O império do direito, cit., p. 171 
Em prosseguimento ao método de Hércules, pode ocorrer de um caso não estar regulado pela legislação positivada, de modo a se exigir outra fonte legítima para dar solução ao caso. A esse respeito, Dworkin menciona o papel do direito costumeiro (common law), com os seus precedentes. Ao se deparar com um caso não regulamentado por lei, consultam-se os precedentes para verificar se os Tribunais já decidiram, anteriormente, alguma questão semelhante que permita afirmar ser devido o ganho de causa a uma das partes litigantes.

A análise empreendida por Hércules, para averiguar a semelhança da questão sub judice com o procedente, não se restringe à linguagem empregada na decisão pretérita ${ }^{143}$, decorre da necessidade de se dar soluções iguais a casos substancialmente semelhantes para não tratar com desigualdade os jurisdicionados. Os fundamentos - argumentos de princípio - justificam a decisão e geram uma justa expectativa no jurisdicionado de que será tratado da mesma forma caso seja processado, ou venha a processar alguém, em termos substancialmente semelhantes. Por outro lado, se os fundamentos do precedente forem políticos, essa mesma expectativa não deve ser gerada, porque não são decorrentes do Direito, como os argumentos de princípio, e por sua natureza não estão sujeitos a um dever de coerência, na medida em que os objetivos e metas coletivas (inerentes ao argumento de política, conforme explicado no Capítulo II.1.3) variam conforme a conjuntura e os propósitos dos governantes. Nesse sentido, Dworkin esclarece que:

"Hércules concluirá que sua doutrina da equidade oferece a

${ }^{143}$ Nota-se uma substancial diferença na interpretação dos precedentes e dos dispositivos legais positivados, na medida em que o que determina a aplicação da lei é a linguagem empregada pelo legislador, ela é o ponto de referência do intérprete, enquanto nos precedentes mais interessa analisar os fundamentos (argumentos de princípios) que justificam a decisão. 
única explicação adequada da prática do precedente em sua totalidade. Extrairá algumas outras conclusões sobre suas próprias responsabilidades quando da decisão de casos difíceis. A mais importante delas determina que ele deve limitar a força gravitacional das decisões anteriores à extensão dos argumentos de princípio necessários para justificar tais decisões. Se se considerasse que uma decisões anterior estivesse totalmente justificada por algum argumento de política, ela não teria força gravitacional alguma.(...) Não poder haver, portanto, nenhum argumento geral de equidade, de acordo com o qual um governo que atende a uma meta coletiva de uma certa maneira em determinada ocasião deve atendê-la dessa maneira, ou mesmo atender à mesma meta, sempre que uma oportunidade paralela se apresentar.",144

De acordo com Dworkin, a adequação ${ }^{145}$ do caso difícil ao precedente que norteará sua resolução não é uma adequação fática absoluta, importa mais perceber os pontos centrais do caso e os argumentos de princípio que a ele deram solução. Por exemplo, há um precedente pela condenação de certa empresa a pagar indenização a um empregado, que sofreu um acidente de trabalho por falta de equipamentos de segurança, com base em um argumento de princípio, segundo o qual todos aqueles que lesam alguém, por negligência, têm o dever de reparar o dano. Na jurisdição de Hércules, para que se verifique a força gravitacional deste precedente, não seria relevante questionar qual o segmento econômico da empresa nele indicada, porque este não seria um ponto

144 DWORKIN, Ronald. Levando os direitos a sério,cit., pp. 177-179

145 Ao mencionar o caso McLoughlin, para se averiguar se há, ou não, direito a ser indenizada pelos danos morais, Dworkin esclarece a questão da adequação da interpretação de Hércules: "Suas opiniões sobre a adequação se irradiam a partir do caso que tem diante de si em uma série de círculos concêntricos. Ele pergunta quais interpretações de sua lista inicial se ajustam aos casos de danos morais do passado, depois quais se ajustam aos casos de dano acidental à pessoa em termos mais gerais, e, em seguida, quais se ajustam aos prejuízos a interesses econômicos, e assim por diante, até encontrar em áreas cada vez mais distantes do caso McLoughlin original. Esse procedimento confere uma espécie de prioridade local àquilo que poderíamos chamar de "áreas" do direito. Se Hércules achar que nenhum dos dois princípios se mostram em contradição frontal com os casos de danos causados por acidentes em sua jurisdição, expandirá seu estudo de modo a incluir, digamos, os casos contratuais, para ver qual desses princípios se ajusta melhor às decisões de contrato, se é que algum deles o faz. Do ponto de vista de Hércules, porém, se um princípio não se ajusta de modo algum ao direito sobre acidentes - se for contestado por quase todas as decisões na área que poderia tê-lo confirmado -, isso o desqualifica seriamente enquanto interpretação aceitável dessa área do direito, mesmo quando se ajusta perfeitamente a outras esferas legais." DWORKIN, Ronald. O império do direito, cit. p. 300 
central do caso, dever-se-ia, por exemplo, verificar se houve negligência, ou não, por parte da empresa ré e se esta foi a causadora exclusiva do dano ao empregado, na medida em que estes seriam os seus pontos centrais. $\mathrm{O}$ fato de se afastar o precedente, porque a empresa nele condenada não pertence ao mesmo segmento econômico da ré, ora em questão, geraria uma iniquidade, segundo a teoria de Dworkin, porque não se trata de um ponto relevante ao caso.

Esse dever de coerência com o precedente semelhante, para que seja equânime a decisão judicial de um caso difícil, não se limita a um único, ou um conjunto limitado de precedentes, sendo sua abrangência muito mais ampla na teoria de Dworkin. Hércules deve buscar uma coerência global, deve verificar se a aplicação de um precedente, em um caso específico, não viola outros precedentes, isto é, outros argumentos de princípio que também deveriam ser levados em consideração para se chegar a uma solução equânime. A visão de Hércules, nesse sentido, deve ser a mais global possível, exige-se que ele conheça e compreenda um grande repertório jurisprudencial, para que possa chegar a uma solução equânime ao julgar o caso sob análise:

"Mas se a força gravitacional do precedente tem por base a ideia de que a equidade exige a aplicação coerente de direitos, Hércules deve então descobrir os princípios que se ajustam não apenas ao precedente específico para o qual algum litigante dirige sua atenção, mas para todas as outras decisões no âmbito de sua jurisdição geral e, na verdade, também às leis, na medida em que estas devem ser vistas como geradas a partir de princípios e não a partir de determinada política. Caso os princípios que ele citar como estabelecidos forem incompatíveis com outras decisões que seu tribunal propõe-se igualmente a sustentar, Hércules não terá cumprido seu dever de mostrar que a decisão que ele tomou é compatível com princípios estabelecidos e, portanto, equânime (fair)." "146

A partir do que se exige para Hércules bem desempenhar a

146 DWORKIN, Ronald. Levando os direitos a sério,cit. p. 181 
judicatura, esclarece-se porque Dworkin atribui a ele este nome. Como foi esclarecido, a coerência na aplicação dos princípios depende de um vasto conhecimento tanto dos precedentes como da Constituição e da legislação infraconstitucional, o que em geral é muito difícil de se alcançar, exigindo um esforço hercúleo por parte dos julgadores, considerando o volume de trabalho destes. $^{147}$

Destaca-se que essa avaliação da coerência dos princípios empreendida por Hércules ${ }^{148}$ se dá em diferentes níveis, desde uma perspectiva vertical, quanto em uma horizontal. A perspectiva vertical exige, por exemplo, que os tribunais inferiores respeitem os argumentos de princípio emitidos pelas decisões dos Tribunais superiores, ao resolver seus litígios; enquanto, a coerência horizontal exigiria manter a coerência no mesmo tribunal entre as diferentes Turmas, ou Câmaras.

Ainda nesse esteio, ressalta-se que os juízes, mesmo diante de idêntico repertório legislativo e jurisprudencial, podem chegar a conclusões diferentes quanto ao que essa coerência aos princípios indica como solução ao caso $s u b$ judice. ${ }^{149}$ Mas isso não significa que não há uma resposta certa ao caso concreto, o que será objeto de análise detalhada em Capítulo próprio deste

\footnotetext{
147 “O direito como integridade, então, exige que um juiz ponha à prova sua interpretação de qualquer parte da vasta rede de estruturas e decisões políticas de sua comunidade, perguntando-se se ela poderia fazer parte de uma teoria coerente que justificasse essa rede como um todo. Nenhum juiz real poderia impor nada que, de uma só vez, se aproxime de uma interpretação plena de todo o direito que rege sua comunidade. É por isso que imaginamos um juiz hercúleo, dotado de talentos sobrehumanos e com um tempo infinito a seu dispor. Um juiz verdadeiro, porém, só pode imitar Hércules até certo ponto. Pode permitir que o alcance de sua interpretação se estenda desde os casos imediatamente relevantes até os casos pertencentes ao mesmo campo ou departamento geral do direito, e em seguida desdobrar-se ainda mais, até onde as perspectivas lhe pareçam mais promissoras." DWORKIN, Ronald. O império do direito, cit. p. 294

148 "Os juízes que aceitam o ideal interpretativo da integridade decidem casos difíceis tentando encontrar, em algum conjunto coerente de princípios sobre os direitos e deveres das pessoas, a melhor interpretação da estrutura política e da doutrina jurídica de sua comunidade." DWORKIN, Ronald. $O$ império do direito, cit. p. 305

149 DWORKIN, Ronald. Levando os direitos a sério,cit. pp. 182-184
} 
trabalho (Capítulo II.3.4).

Cumpre ressaltar que a consistência/coerência que Hércules procura nas decisões institucionais, tanto dos precedentes dos Tribunais, como na legislação positivada, não é absoluta ${ }^{150}$. Ele admite a existência de erros nesta história institucional. Para lidar com estes erros, Dworkin esclarece que Hércules deve distinguir a autoridade específica daquela decisão institucional (o poder de produzir certos resultados por ela expressamente previstos) de sua força gravitacional (o poder de continuar a produzir resultados no futuro, orientando novas decisões, em casos diversos daquele previsto).

Para avaliar esta questão da força gravitacional e do erro é importante destacar o papel do argumento de equidade ${ }^{151}$, importante para Hércules, enquanto comando que exige tratar todos igualmente, na medida de suas semelhanças, no passado, presente e futuro (coerência intertemporal), aplicado às decisões judiciais.

150 Quanto à necessidade de coerência da decisão judicial com o conjunto da prática jurídica e sua eventual contradição com algum de seus elementos, menciona-se ANDREW ALTMAN, professor de filosofia na George Washington University: "The coherence does not have to be perfect, for Dworkin allows that the soundest theory may characterize some rules and legal outcomes as mistakes, but coeherence with most of setlled law is demanded. In principle, the soundest theory is to encompass every area of law: every branch of the common law, all statutes, the whole body of administrative law, and the entire range of constitutional law." ALTMAN, Andrew. Legal Realism, Critical Legal Studies, and Dworkin, Philosophy \& Public Affairs, vol. 15, n. ${ }^{\circ}$, Princeton: Princeton University Press, 1986, p. 211

151 O princípio da equidade, na obra de Dworkin, decorre do ideal de integridade do Direito por ele defendido, na medida em que todos devem ser tratados com igual consideração e, por isso, em casos semelhantes submetidos à apreciação judicial, há esse dever de coerência na aplicação do Direito as partes litigantes. A esse respeito, menciona-se a professora ROBIN WEST, da Georgetown University, a qual afirma o que segue: “(...) Dworkin has shown that integrity imposes constraints upon and provides guidance to the work of judges in constitutional cases: every constitutional case that comes before a court must be decided by recourse to the same moral principles that have dictated results in relevant similar cases in the past. Any group or individual challenging the constitutionality of legislation which adversely affects his or her interests is entitled - morally and legally - to a reasoned decision illustrating why moral principles held constitutionally dispositive in earlier cases regarding similarly situated groups should not be equally dispositive for him or her." WEST, Robin. Integrity and Universality: A comment on Ronald Dworkin's Freedom's Law, Fordham Law Review, vol. 65,1997, p. 1313 
A aplicação do argumento de equidade, na decisão judicial a ser tomada por Hércules, depende que o argumento de princípio evocado na decisão institucional tomada pelo legislativo ou tribunais no passado (por exemplo, dever de indenizar quando houver dano por negligência) seja ainda aceito pela comunidade política no presente, que não seja obsoleto. Se o argumento de princípio que fundamenta a decisão institucional for ultrapassado, é difícil que ele continue a gerar novas decisões judiciais que o tenham como base. Nesses casos, Dworkin defende que o argumento de equidade cede espaço ao novo entendimento, pois ficou enfraquecido neste cenário.

Além disso, outro fator que relativiza a aplicação do argumento de equidade é se Hércules entender, com base na moralidade política da comunidade, que um argumento de princípio, que fundamentou certa decisão institucional pretérita, passou a mostrar-se injusto, na conjuntura atual, e que, portanto, não deveria ser aplicado a casos semelhantes a mesma solução. Neste caso, mesmo que o argumento de princípio injusto mantenha-se aceito pela comunidade, não mais poderá ser sustentado pelo argumento da equidade:

"Hércules aplicará, portanto, pelo menos duas máximas na segunda parte de sua teoria dos erros. Se puder demonstrar, por argumentos históricos ou pela menção a uma percepção geral da comunidade jurídica, que um determinado princípio, embora já tenha tido no passado atrativo suficiente para convencer o poder legislativo ou um tribunal a tomar uma decisão jurídica, tem agora tão pouca força que é improvável que continue gerando novas decisões desse tipo - então, nesse caso, o argumento de equidade que sustenta este princípio se verá enfraquecido. Se Hércules puder demonstrar, por meio de argumentos de moralidade política, que esse princípio é injusto, a despeito de sua popularidade, então o argumento de equidade que sustenta o princípio estará invalidado." 152

152 DWORKIN, Ronald. Levando os direitos a sério,cit. p. 191 
A moralidade política ${ }^{153}$ é parte indissociável da tarefa de construir decisões corretas para Hércules. No seu processo interpretativo, especialmente nos casos difíceis, quando se exige que o julgador recorra a princípios, cuja conceituação adequada depende da moralidade política da comunidade, para resolver a questão, Hércules deve buscar saber o que eles realmente exigem. Essa busca para se chegar ao melhor conceito de um princípio, diante de um caso concreto, pode se operar de duas formas centrais, conforme propõe a teoria de Dworkin, que vão variar conforme a valorização que o intérprete dá a um determinado princípio: a primeira é quando Hércules pessoalmente não valoriza um dado princípio; a segunda, e mais recorrente, é quando ele valoriza este princípio inserido em sua prática jurídica.

No primeiro caso, quando Hércules não valoriza pessoalmente um princípio, isso não permite que ele afaste já de antemão a sua aplicação em um caso que se apresente para julgamento; ao contrário, deve avaliar se o princípio deve, ou não, influenciar o seu julgamento procurando encontrar um conceito apoiado na moralidade da comunidade.

Antes de prosseguir, é necessário esclarecer que a moralidade da comunidade difere da moralidade da maioria que impera naquele momento, isto

153 CHARLES KELBLEY destaca a importância de se recorrer à moralidade política, na teoria de Dworkin, para decidir um caso difícil, cuja resolução não depende apenas de voltar-se às regras explícitas promulgadas, exigindo dos juízes essa consideração à moralidade política da comunidade na construção de sua decisão: "According to Dworkin, to understand the law more fully, one must routinely interpret it in light of political morality. In hard cases, a judge cannot escape the necessity to observe the law from a moral point of view by asking what interpretation places the law in its best or most politically attractive light. A judge must look not merely at the explicit rules previously endorsed, but also at the principles upon which these rules depend. A judge must then ask what further principles have been recognized in past decisions. Interpretation, so understood, imposes a duty upon judges to invoke their sense of political morality (...)" (KELBLEY, Charles. Makers and receivers: judicial heresy and the tempting of America, Fordham Urban Law Journal, vol. 18, 1990, p. 67). O referido autor faz questão de ressaltar na nota de rodapé número 92, do artigo ora em comento, que Dworkin não traz, em seus textos, uma definição precisa de moralidade política, mas certamente a diferencia da moralidade pessoal/privada do julgador, e a considera como algo público, pertencente à comunidade, e decorrente da história política e das decisões políticas passadas, dentre as quais se incluem os precedentes judiciais. 
é, não importa avaliar o que a maioria dos membros da comunidade entende como a correta interpretação de um princípio em um caso concreto, o que ela pretende que esse princípio faça. A moralidade da comunidade influencia decisivamente a decisão judicial de Hércules, todavia, esta não deve ser nem a moralidade da maioria, tampouco decorrer da convicção pessoal do julgador, a esse respeito Dworkin esclarece que:

\begin{abstract}
“A teoria da decisão judicial de Hércules não configura, em momento algum, nenhuma escolha entre suas próprias convicções políticas e aquelas que ele considera como as convicções políticas do conjunto da comunidade. Ao contrário, sua teoria identifica uma concepção particular da moralidade comunitária como um fator decisivo para os problemas jurídicos; essa concepção sustenta que a moralidade comunitária é a moralidade política que as leis e as instituições da comunidade pressupõem." 154
\end{abstract}

Feito este importante esclarecimento, prossegue-se na análise do primeiro caso, quando o julgador pessoalmente não valoriza um determinado princípio, ao qual, para decidir sua influência em um caso concreto, necessita buscar um conceito adequado a este princípio com base na moralidade política da comunidade, mesmo não o valorizando. Nesses casos, Hércules deve, em um primeiro momento, "compreender sua linguagem, quais são os casos claros e estabelecidos aos quais o conceito se aplica"; superada essa primeira análise, ele "tentará colocar-se, tanto quanto possa, no contexto mais geral das crenças e atitudes daqueles que valorizam o conceito, para ver os casos claros através dos olhos deles" ${ }^{155}$. A partir da análise desse segundo momento, Hércules será capaz de encontrar uma teoria geral daquele conceito, de modo que possa valorá-lo e aplicá-lo no caso concreto de acordo com a moralidade da comunidade sobre aquele princípio, mesmo que pessoalmente não lhe atribua grande valor.

154 DWORKIN, Ronald. Levando os direitos a sério,cit. p. 197

155 DWORKIN, Ronald. Levando os direitos a sério,cit. p. 199 
O segundo caso trata-se da situação oposta, quando Hércules valoriza o princípio que analisa. De acordo com Dworkin, esta é regra, porque geralmente os juízes se identificam quanto àquilo que consideram importante, porquanto também são membros da comunidade política da qual são julgadores, compartilhando desse substrato comum. Nestes casos, Dworkin esclarece que Hércules, diferentemente do ocorreu no primeiro caso, tem uma familiaridade com o princípio e de antemão já o valoriza, ao julgar um caso concreto em que irá aplicá-lo.

Portanto, nestes casos, para valorar o quanto ele será influente e determinante em sua decisão, com base na moralidade política, ele não precisa fazer um movimento de alteridade como fez no primeiro caso, em que procurava analisar as crenças e atitudes daqueles que valoravam o conceito como sua referência no seu processo interpretativo. Ele agora pode ser protagonista deste movimento, ele procurará ver qual a melhor forma de se aplicar àquele princípio em respeito à moralidade da comunidade, tendo a si mesmo como referência. Não se trata de impor sua convicção pessoal, para Dworkin, o papel dela é apenas relevante na medida em que lhe permite acessar a moralidade institucional da comunidade.

"Ele começará a partir de dentro, e não de fora, do esquema de valores que aprova o conceito, e poderá colocar a si próprio, e não algum hipotético eu, questões que remetam à moralidade profunda que dá valor ao conceito. A nítida distinção entre moralidade fundamental e institucional irá apagar-se, não porque a moralidade institucional seja desalojada por convicções pessoais, mas porque as convicções pessoais terão se tornado, para ele, a mais favorável via de acesso à moralidade institucional."

156 DWORKIN, Ronald. Levando os direitos a sério,cit. p. 200 
Ainda a esse respeito, reitera-se que os juízos próprios de Hércules sobre os direitos das partes (direitos institucionais jurídicos), por exemplo, o que um princípio exige se devidamente aplicado em um caso difícil, não se confundem com sua convicção pessoal, embora ele saiba que ela seja uma via de acesso à moralidade institucional importante a esse juízo, conforme explanado acima, pois Hércules sabe que sua opinião para ser Direito precisa estar calcada em algo maior, que é a moralidade política da comunidade a qual remeterá, necessariamente, à consulta do seu registro institucional (decisões políticas passadas registradas na história daquela comunidade política). ${ }^{157}$

Hércules, certamente, é muito mais limitado em suas decisões, nos casos difíceis, por defender a existência de direitos prévios para resolvê-los do que um juiz positivista, partidário das ideias de Hart, que primeiro encontrará os limites explícitos da norma e, quando entender que o caso não se encontra regulado por ela, decidirá com base em seu poder discricionário, ou seja, será livre para legislar no caso concreto ${ }^{158}$. Se esse juiz hartiano, que assume este papel de legislador nos casos difíceis, realmente pretender ser coerente ao seu propósito, deverá decidir de acordo com a vontade da maioria, o que nem sempre se mostra acertado à moralidade política da comunidade, a qual Hércules se vincula, conforme já foi mencionado.

Por último, para encerrar esta etapa da construção do julgamento dos casos difíceis pelo juiz Hércules, menciona-se a crítica de Habermas sobre o discurso monológico do juiz Hércules ${ }^{159}$.

157 DWORKIN, Ronald. Levando os direitos a sério,cit. p. 196

158 DWORKIN, Ronald. Levando os direitos a sério,cit. p. 195

159 "As objeções até aqui levantadas contra o sentido e viabilidade de uma teoria do direito ideal, capaz de proporcionar a melhor interpretação judicial dos direitos e deveres, da história institucional, da estrutura política e de uma comunidade constituída segundo o direito do Estado constitucional, partiram da premissa de que essa teoria possui um único autor - o respectivo juiz, que escolheu Hércules como seu modelo. Ora, as próprias respostas que Dworkin deu, ou poderia dar, a seus críticos levantam as primeiras dúvidas com relação à possibilidade de se manter esse princípio 
A crítica consiste na afirmação de que Hércules, na teoria de Dworkin, seria o único intérprete das normas, pois supostamente teria um privilégio cognitivo, e não permitiria, em seu processo interpretativo, a comunicação com os demais membros da comunidade política por meio de um debate argumentativo. Habermas faz referência direta a Peter Häberle ${ }^{160}$, ao mencionar a necessidade de construção da interpretação por uma perspectiva coletiva, segundo a qual todos são intérpretes e devem participar, ativamente, da interpretação dos normativos que regem a comunidade (a noção de Peter Häberle de sociedade aberta aos intérpretes da Constituição).

Com relação a essa crítica, pode-se concordar com Habermas apenas no sentido de que o juiz Hércules de Dworkin, realmente, faz sua interpretação construtiva sozinho. Todavia, parece não ser possível fazer diferente, o que retira a força da crítica habermasiana. Explica-se: os juízes, assim como qualquer pessoa, interpretam o que o Direito exige e chegam às suas conclusões (decisões judiciais) a partir dos elementos que estão à sua disposição e que não remontam apenas à sua bagagem prévia de conhecimento, mas que sofre acréscimos específicos com a argumentação que está nos autos do

monológico. Pois o ponto de vista da integridade, sob o qual o juiz reconstrói racionalmente o direito vigente, é expressão de uma ideia de Estado de direito que a jurisdição e o legislador político apenas tomam de empréstimo ao ato de fundação da constituição e da prática dos cidadãos que participam do processo constitucional. Dworkin oscila entre a perspectiva dos cidadãos que legitima os deveres judiciais e a perspectiva de um juiz que tem a pretensão de um privilégio cognitivo, apoiando-se em si mesmo, no caso em que a sua própria interpretação diverge de todas as outras." HABERMAS, Jürgen. Direito e democracia: entre facticidade e validade, cit., p. 276

160 “(...) a teoria da interpretação deve ser garantida sob a influência da teoria democrática. Portanto, é impensável uma interpretação da Constituição sem o cidadão ativo e sem as potências públicas mencionadas. Todo aquele que vive no contexto regulado por uma norma e que vive com este contexto é, indireta ou, até mesmo diretamente, um intérprete dessa norma. O destinatário da norma é participante ativo, muito mais ativo do que se pode supor tradicionalmente, do processo hermenêutico. Como não são apenas os intérpretes jurídicos da Constituição que vivem a norma, não detêm eles o monopólio da interpretação da Constituição." HÄBERLE, Peter. Hermenêutica Constitucional - A sociedade aberta dos intérpretes da Constituição: Contribuição para a interpretação pluralista e 'procedimental' da Constituição. Trad. Gilmar Ferreira Mendes, Sergio Antonio Fabris Editor, 1997, pp. 14-15 
caso sub judice. Hércules dialoga, amplamente, com a comunidade política e com as partes envolvidas no caso, para que tenha o máximo de elementos relevantes possíveis, na sua empreitada de construir a resposta correta. Todavia, a construção em si das suas conclusões (a sua resposta) é solitária.

Há um dever de decidir e seria um verdadeiro caos, se, a cada decisão judicial, fosse feito um plebiscito, em que todos os interessados manifestassem suas opiniões e interpretações sobre as normas, votando por uma ou outra decisão. Saliente-se que não se nega o fato de que qualquer pessoa, em tese, é capaz e deve interpretar as normas que regem a sua comunidade política, até mesmo para orientar as suas ações. Todavia, a elas não é atribuído o poder jurisdicional, isto é, elas não estão incumbidas, institucionalmente, de resolver conflitos, ao contrário, dos juízes. Além disso, seria um erro, para Dworkin, submeter a decisão judicial à vontade da maioria momentânea da comunidade política ${ }^{161}$, porque esta vontade não, necessariamente, corresponderá ao Direito como integridade por ele proposto. Por isso, Dworkin propõe que Hércules, em seu processo interpretativo do Direito como integridade, não deve dialogar apenas com o presente (os argumentos das partes e demais intervenientes no processo), mas deve também estabelecer uma conexão forte com o passado, que lhe permita reconstruir com a máxima precisão possível a moralidade política da comunidade, projetando-a também aos seus anseios futuros.

Após este esclarecimento sobre Hércules e a crítica e Habermas, levanta-se uma última crítica, a qual muitos poderiam endossar, que esse tipo de juiz não existe na realidade, especialmente, considerando a conjuntura atual do Judiciário, que tende a estar continuamente sobrecarregado com as demandas.

161 O Direito como integridade deve ser sempre inserido na concepção constitucional da Democracia, segundo a qual a verdadeira Democracia exige que todos os cidadãos sejam tratados com igual consideração, ou seja, afasta a concepção de Democracia centrada na vontade da maioria (premissa majoritária), a qual admitiria não tratar todos com igual consideração (vide inúmeros exemplos de repressão às minorias). Esta temática será devidamente tratada no Capítulo III.3.1. 
Poder-se-ia afirmar que nenhum juiz tem tempo para desenvolver o método de Hércules, que toda essa construção teórica não é relevante ${ }^{162}$. Todavia, aqueles que fazem esse tipo de afirmação esquecem-se que os ideais existem e que eles devem ser valorizados, mesmo que apenas possibilitem a reflexão e a crítica da prática estabelecida na conjuntura atual. Isso não retira o brilhantismo do método de Hércules, ou da teoria de Dworkin, que não é composta de um arcabouço teórico desprendido da realidade; ao contrário, ele constrói sua teoria do Direito ao lado da sua teoria da decisão judicial, como braços que se comunicam e caminham juntos como já foi demonstrado ao longo deste trabalho. A sua teoria tem aplicabilidade prática e, naquilo que ainda não se consegue implementar por problemas contingenciais de volume de trabalho, serve como um ideal a ser perseguido ${ }^{163}$.

\section{II.3.2. O PODER DISCRICIONÁRIO DO JUIZ}

Em continuidade a este Capítulo sobre a decisão nos casos difíceis, é importante aprofundar a diferença do que Dworkin propõe para resolver um

162 "Hércules nos é útil exatamente porque é mais reflexivo e autoconsciente do que qualquer juiz verdadeiro precisa ou, dada a urgência de trabalho, precisaria ser. Sabemos que os juízes reais decidem a maioria dos casos de maneira bem menos metódica, mas Hércules nos mostra a estrutura oculta de suas sentenças, deixando-as assim abertas ao estudo e à crítica. Além do mais, precisamos ter o cuidado de estabelecer uma distinção entre os dois sentidos nos quais se poderia dizer que ele tem mais poderes do que qualquer juiz verdadeiro. Ele trabalha tão mais rapidamente (e seu tempo disponível é tão maior) que pode explorar caminhos e ideias que os outros não podem; pode seguir não apenas uma ou duas direções evidentes ao ampliar o alcance dos casos que estuda, mas todas as linhas existentes. Esse é o sentido em que seus objetivos podem ser muito mais altos que os dos outros: ele pode aspirar a testar hipóteses mais abrangentes, enquanto os testes das hipóteses pelos outros devem ser parciais. Mas ele não tem acesso a mistérios transcendentais que são obscuros para eles. Seus juízos sobre adequação e moral política são feitos da mesma matéria e tem a mesma natureza que os deles. Ele faz o que eles fariam se tivessem toda uma carreira a dedicar a uma única decisão; precisam não de uma concepção de direito diferente da dele, mas de algo que ele nunca precisou cultivar: eficiência e capacidade de administrar com prudência." DWORKIN, Ronald. $O$ império do direito, cit. p. 316

163 Nesse sentido, AULIS AARNIO afirma que os juízes, embora não possam ser Hércules, devem se aproximar dele o máximo que conseguirem: "No single person can be a Hercules, but everybody can, no doubt, intelligibly postulate such a superhuman being. Therefore every judge can and should try to get as close to Herculean competence as he can." AARNIO, Aulis. The rational as reasonable, cit., pp. 163-164 
caso difícil daquilo que os positivistas, como Hart, defendem como sua teoria para estes $\operatorname{casos}^{164}$. Já se esclareceu parte da teoria da decisão judicial de Dworkin sobre os casos difíceis nos Capítulos supra, pelo menos o suficiente para ver com clareza a distinção entre as propostas apresentadas. Por ora, esclarece-se que com relação ao embate entre Hart e Dworkin, nos Capítulos II.1.2 e II.1.3., trabalhou-se as principais diferenças entre o pensamento destes autores, de maneira mais genérica, atinente à teoria geral e conceituação do Direito empreendida por ambos. Aqui o propósito mostra-se mais específico, pois apontará para os casos difíceis como objetivo central, procurar-se-á demonstrar o contraponto positivista da teoria de Dworkin como estratégia para resolver estes casos - aquilo que se denominou na doutrina hartiana de "poder discricionário dos juízes".

É prudente que se inicie a análise de quando se deve apelar ao poder discricionário dos juízes, com base nas palavras do próprio Hart, a fim de para se evitar eventuais distorções do que o filósofo propõe:

\begin{abstract}
"A interpretação que apresento neste livro é a de que as normas e princípios jurídicos, identificados em termos gerais pelos critérios oferecidos pela norma de reconhecimento, muitas vezes têm o que costumo chamar de "textura aberta". Assim, quando se quer saber se certa norma se aplica a um caso específico, a lei não oferece resposta em nenhum dos dois sentidos, mostrando-se, portanto, parcialmente indeterminada. Esses não são simples "casos difíceis", casos polêmicos no sentido de que juristas sensatos e bem-informados podem discordar sobre qual a resposta juridicamente correta; o direito é, nesses casos, fundamentalmente incompleto: não oferece nenhuma resposta aos problemas em pauta. Estes não são
\end{abstract}

164 A respeito da divergência da teoria proposta por Hart e Dworkin, para resolver os casos difíceis, JEREMY M. MILLER esclarece que: "Professor Dworkin, however, unlike the then prevailing "positivist" position espoused by his mentor H. L. A. Hart, explained that judges deciding cases truly were not allowed unmitigated discretion in filling these gaps. Instead, they were bound by "principles." Among the principles expressed by Dworkin were: not allowing one to profit by his own wrongs, equal treatment of society's members, and fairness" MILLER, Jeremy M. Law's Empire: Book Review, Campbell Law Review, vol. 9, 1986, p. 204 
regulamentados juridicamente; e, para chegarem a uma decisão em tais casos, os tribunais precisam exercer a função legislativa limitada que denomino "discricionariedade". Dworkin rejeita a ideia de que a lei possa ser assim incompleta, deixando lacunas a serem preenchidas pelo exercício dessa discricionariedade criativa." 165

Desse modo, Hart afirma que se deve apelar ao poder discricionário dos juízes, ao julgar um caso difícil, quando de fato há uma lacuna no Direito, de modo a não se poder resolver o caso com base nele. De acordo com Hart, esse poder discricionário é atribuído pelo Direito aos juízes nestes casos difíceis, porém, ele não seria equivalente ao poder atribuído ao Poder Legislativo, que teria o poder de mudar o Direito existente, na formulação de uma regra nova que irá regular o caso concreto. Pela teoria hartiana, o papel do juiz não é extrapolar, ou contradizer os dispositivos legais explícitos, deve atuar com consciência em respeito às suas convicções e valores. O juiz seria, desse modo, um "legislador consciencioso" na teoria do poder discricionário de Hart. $^{166}$

Para Dworkin, o exercício do poder discricionário, conforme externado na teoria de Hart, embora venha revestido de alguma forma de limitação do seu exercício, pode ser visto como um poder discricionário em sentido forte ${ }^{167}$, isto é, quando "um juiz esgota as regras à sua disposição, ele

165 HART, H. L. A. O conceito de direito, cit., p. 326

166 HART, H. L. A. O conceito de direito, cit., p. 352

167 NEIL MACCORMICK critica a posição de Dworkin sobre o poder discricionário enunciado por Hart em sua teoria. Explica-se. Ele afirma que Dworkin acredita que sua teoria, em razão de defender a aplicação de princípios, nos casos difíceis, não precisaria recorrer a esse poder discricionário em sentido forte, ou seja, haveria de fato uma limitação ao juiz por um padrão jurídico. Neil MacCormick refuta esta ideia de Dworkin, defende que aplicar princípios, na medida em que estes não determinam um resultado específico, como as regras, exigem do juiz recorrer a este poder discricionário em sentido forte: "Hence, there is a decided oddity in the criticism of Hart's theory of judicial discretion advanced by Ronald Dworkin. Dworkin says that because a legal system is always founded on principles, therefore judges do not really have 'strong' discretion. It is not true, he says, that when the rules fail to give a clear answer, the judge has discretion unlimited by any legal standards. That is quite correct in itself. The judge's discretion is discretion to do as seems right and proper consistent with legal principles, legal values, and other relevant legal standards. But that is as 
possui o poder discricionário, no sentido de que ele não está obrigado por quaisquer padrões derivados da autoridade da lei ${ }^{, 168}$.

Todo o esforço positivista para criar uma teoria para resolver os casos difíceis, isto é, aqueles em que supostamente não haveria padrões derivados da autoridade da lei, é decorrente do fato deles não aceitarem o importante papel desempenhado pelos princípios positivados e não-positivados (oriundos da moralidade política da comunidade), para constituírem uma obrigação jurídica. A esse respeito, importa ressaltar que se ele estiver explícito na legislação, isto é, não decorrer implicitamente da moralidade política da comunidade, poder-se-ia considerá-lo como parte do Direto para o positivista; todavia, ele continuará incapaz de produzir um resultado específico no caso concreto, isto é, uma obrigação jurídica.

Dworkin, por sua vez, discorda desse argumento, na medida em que defende a capacidade dos princípios de criar obrigações jurídicas, mesmo que não ditem resultados de antemão (prima facie) como as regras. Para Dworkin, a decisão fundada em princípio não é oriunda do poder discricionário como querem os positivistas, ao contrário, afirma que:

“(...) argumentamos em favor de um princípio e seu peso apelando para um amálgama de práticas e outros princípios, nos quais as implicações da história legislativa e judiciária aparecem juntamente com apelos às práticas e formas de compreensão compartilhadas pela comunidade. Não existe um papel de tornassol para testar a consistência desse argumento ele é matéria que depende de juízo e pessoas razoáveis podem

strong a discretion as there can possibly be. The decision how it is right and proper to interpret and apply vague-because-general principles involves evaluating consequences of a ruling this way or that. This is a matter of settling, not finding, priorities within states/societies about moral and political priorities; nor is there any reason to suppose that there is some ideal judge's or observer's standpoint from which to establish the true moral and political priorities served by the legal system." MACCORMICK, Neil. H. L. A. Hart, cit., p. 163

168 DWORKIN, Ronald. Levando os direitos a sério, cit., p. 55 
discordar a respeito dela."

Hart, em uma tentativa de manter firme sua teoria positivista (de acordo com Dworkin, desconsiderando elementos não explícitos na legislação mesmo que relevantes ${ }^{170}$ ) e conciliá-la com o poder discricionário dos juízes a ser utilizado nos casos difíceis, afirma que o próprio Direito deve permitir o exercício desse poder discricionário (explicitá-lo) e dar os limites necessários a ele.

Todavia, não demonstrou, empiricamente, tal previsão na legislação inglesa, norte-americana, ou de qualquer outro país. Como Hart pretende criar uma teoria geral do Direito fundada na descrição, esta pode ser apontada como uma grande falha em seu propósito, que, ao apresentar a teoria do poder discricionário judicial, para resolver os casos difíceis, acaba rompendo com os limites de sua suposta descrição avalorativa do Direito, na medida em

169 DWORKIN, Ronald. Levando os direitos a sério,cit. p. 58

170 Destaca-se a esse respeito, a crítica de JOSEPH RAZ a esta posição de Dworkin, segundo a qual a teoria de Hart, supostamente, não admitiria ser levados em consideração elementos que não estão explícitos na legislação positivada. A crítica concentra-se em dois argumentos centrais, quais sejam, (i) para compreensão do significado da lei e dos precedentes, na teoria de Hart e de outros positivistas legais, seria necessário ter uma considerável base prévia de informações (background) sobre a prática jurídica, que não se restringe ao dispositivo legal analisado; e (ii) a regra de reconhecimento formulada por Hart, ao contrário do que Dworkin defende, não seria incompatível ao que está implícito na legislação, porque a sua função é apenas de identificar os atos (leis, precedentes etc) que criam Direito: "Dworkin would require different arguments, some of which he has indeed deployed in later years, to show that Hart's theory cannot allow for the Constitution being part of American law. His stated criticism is so obviously unsustainable that one is compelled to conclude that his real target lay elsewhere. What it might have been is open to speculation. One suggestion is that Dworkin was implicitly arguing that Hart's theory recognizes as law only, to use Lyons's term, "explicit" law and denies the existence of "implicit" law. (....) First, to understand what the law states, to understand the plain meaning of statutes and judicial decisions, requires a good deal of background information. (...) To that extent, it is true that the Rule of Recognition does not and cannot include criteria which identify the implied law. But do we need such criteria? Isn't is enough to say that what is implied by legislation and precedent is law as well? To expect the Rule of Recognition to include criteria for the identification of implied law is to misconceive its function. In a sense it does not even contain criteria for the identification of explicit law. All it does, and all it is meant to do, is to identify which acts are acts of legislation and which are the rendering of binding judicial decisions, or more generally, which acts create law. The Rule of Recognition does not help one to understand what is the law thus created, whether it is stated or implied.” (g.n.) RAZ, Joseph. Dworkin: a new link in the chain, California Law Review, vol. 74, 1986, pp. 1106-07 
que não demonstra empiricamente o que afirma, cria de fato algo inovador.

De acordo com Hart, as principais críticas de Dworkin à sua teoria sobre o poder discricionário dos juízes consistem em: (i) esta não corresponder à prática jurídica, na medida em que toda discussão do processo, entre os advogados das partes, promotores, e demais interessados, tende a afirmar direitos e deveres já existentes das partes, não pressupondo um processo de criação de Direito novo; (ii) tratar-se de uma prática antidemocrática, na medida em que os juízes não são legisladores em vista da constitucional separação dos Poderes; e, por fim, (iii) por ela tratar-se de uma prática injusta, pois não permite que as partes planejem suas ações, tendo em vista que o direito novo oriundo do exercício do poder discricionário é ex post facto. ${ }^{171}$

Hart defende-se dessas críticas contra o poder discricionário. Ele afirma contra o primeiro argumento que, embora não seja reconhecida expressamente no litígio essa criação de Direito novo pelo argumento das partes e dos juízes, ela acontece na prática; contra o segundo argumento afirma que os juízes defendem a Democracia, na medida em que fazem controle de constitucionalidade das leis criadas pelo Poder Legislativo, além disso, afirma que nas democracias modernas a separação dos Poderes não é absoluta, sendo necessária essa intersecção de funções; por fim, contra o terceiro argumento afirma que nos casos difíceis, por sua condição de não ser regulamentado de maneira completa pelo Direito, ou por, efetivamente, não ser regulado, não se fere a expectativa jurídica que as partes poderiam ter quanto ao ganho, ou perda da causa. ${ }^{172}$

Quanto à defesa de Hart, pode-se dizer o seguinte: (i) os juízes não

${ }^{171}$ HART, H. L. A. $O$ conceito de direito, cit., pp. 353-356

${ }^{172}$ HART, H. L. A. $O$ conceito de direito, cit., pp. 353-356 
fazem o que Hart diz que eles fazem, nos casos difíceis, quando não há uma regra específica a resolver a questão, tendem a recorrer a princípios para resolvê-la, ao invés de criar um Direito novo como Hart defende; (ii) quanto à possibilidade dos juízes legislarem, sob o argumento de que eles fazem controle

de constitucionalidade e, por essa lógica, se podem saber o que é uma lei adequada à Constituição, poderiam também criá-la, nos exatos termos da Constituição em casos difíceis, rebate-se com o fato de que Hart, ao defender esta posição, esquece-se de que a Constituição inglesa, ou a norte-americana, não atribui esse papel de legislador sui generis ao Judiciário quando este se depara com casos difíceis; e (iii) ao contrário de Hart, Dworkin defende que as partes mesmo nos casos difíceis têm direito a ganhar, ou perder a causa, com base em obrigações jurídicas fundadas nos princípios e não nas regras, portanto, é incorreto afirmar que não há uma justa expectativa.

Feita a elucidação sobre a teoria hartiana para resolver os casos difíceis, de modo a pontuarem-se as falhas desta teoria e principais diferenças com a teoria proposta por Dworkin, passa-se à penúltima etapa dessa caminhada sobre a decisão nos casos difíceis, anterior à polêmica tese da única resposta certa nos casos controversos, que é a definição dos direitos institucionais e jurídicos na teoria de Dworkin.

\section{II.3.3. DIREITOS INSTITUCIONAIS E JURÍDICOS}

Como foi mencionado, antes de se apresentar a tese da única resposta certa nos casos controversos/difíceis, faz-se necessário esclarecer um relevante ponto na decisão desses casos que é aquele atinente aos direitos que devem ser considerados ao decidi-los. Dworkin esclarece que, diferentemente do defendido pelos positivistas alinhados a Hart, não se decide um caso difícil criando-se um direito novo tal qual faz o legislador. Ao contrário, sua teoria da 
decisão judicial defende que os direitos sobre os quais se devem fundamentar uma decisão sobre um caso difícil já existem, em geral, na forma de princípios do qual se extrairá uma regra particular ao caso concreto sub judice. De qualquer forma, sendo o caso difícil, ou fácil, pela teoria de Dworkin, os direitos sobre os quais os juízes devem fundamentar suas decisões são institucionais e não preferenciais e devem ser jurídicos ${ }^{173}$.

Os direitos institucionais, como o próprio nome indica, são decorrentes das instituições, as quais podem ser autônomas, ou não. Se forem autônomas espera-se que apenas se apele às regras estabelecidas para resolver a questão em foco, e não a outros elementos a ela externos (e.g., moralidade política), que poderiam trazer consequências benéficas às partes, ou à comunidade que a circundeia, mas que não estavam previstos no regulamento. A esse respeito, Dworkin ${ }^{174}$ menciona o jogo de xadrez como uma instituição autônoma, segundo a qual os participantes vencerão, ou perderão, a partida com base em suas jogadas reguladas conforme as regras de xadrez estabelecidas, e não conforme um direito preferencial, segundo o qual se um participante for pobre e o outro rico e estiver valendo um prêmio em dinheiro a partida, deverá ser declarado vencedor o jogador menos abonado.

Ao reverso do jogo de xadrez, as instituições jurídicas não são autônomas. Elas deixam em aberto muitas questões, o que inclusive é esperado dada a complexidade da sociedade contemporânea. Deve-se recorrer a elementos externos ao "regulamento", que na teoria de Dworkin seriam atinentes à moralidade política da comunidade. Pode-se argumentar que as

\footnotetext{
173 “A tese dos direitos estipula que os juízes decidem os casos difíceis por meio da confirmação ou negação dos direitos concretos. Mas os direitos concretos nos quais os juízes se apóiam devem ter duas outras características. Devem ser institucionais e não preferenciais; devem ser direito jurídicos em vez de outros tipos de direitos institucionais." DWORKIN, Ronald. Levando os direitos a sério, cit., p. 158

174 DWORKIN, Ronald. Levando os direitos a sério, cit. p. 159
} 
pessoas têm direitos com base nessa moralidade, mesmo que estes não estejam previstos expressamente no livro das regras. Considerando que esses direitos decorrentes da moralidade política são fundados em algo prévio e de conhecimento geral (dado que todos, em tese, podem conhecer com base em juízos próprios a moralidade política de sua comunidade), não se pode afirmar que se trata de um direito novo ex post facto, como ocorre na teoria do poder discricionário de Hart.

Os direitos institucionais, na tese dos direitos de Dworkin, por serem produzidos por instituições não autônomas, no sentido acima explanado, por vezes podem não ser tão claros quanto aos de um jogo de xadrez e, por essa razão, vir a exigir do intérprete um esforço maior na construção de sua decisão sobre os direitos institucionais aplicáveis ao caso.

Nos casos fáceis em que há uma regra clara aplicável, como, por exemplo, aquela que fixa um limite de velocidade aos carros em certa estrada, os direitos institucionais aplicáveis são bastante óbvios e dependem apenas de se recorrer à lei promulgada, não exigindo do intérprete maiores considerações acerca de outros elementos, que seriam relevantes à formação do seu juízo. Nesse sentido, operam como em um jogo de xadrez.

Por outro lado, nos casos difíceis a questão mostra-se de forma diversa. $\mathrm{O}$ reconhecimento de direitos institucionais depende de se recorrer a algo que vai além da literalidade do diploma legal, ou dos precedentes, exigindo-se do intérprete uma compreensão maior da sua própria prática e do papel que desempenha na comunidade. $O$ fato desse direito institucional que se irá encontrar, no processo interpretativo, não estar expresso na lei, ou no precedente, o qual seria obtido por meio de um processo silogístico perfeito, não lhe retira a qualidade de ser institucional. Somente não teria essa qualidade, se 
partissem do pressuposto que toda instituição deve ser autônoma, como em um jogo de xadrez, o que seria absolutamente falho face à sociedade complexa em que se vive. Não é possível afirmar que a lei e o precedente se bastam, e que, portanto, são capazes de resolver toda e qualquer questão. O Direito e as instituições que dele fazem parte carecem dessa heteronomia, a qual se revela com maior ênfase nos casos difíceis, quando se deve recorrer a princípios decorrentes da moralidade política da comunidade.

Esclarecido o que se considera, enquanto direito institucional, dáse o próximo passo na tese dos direitos de Dworkin, a questão se pode ser desconsiderado um direito institucional, em favor de um direito preferencial, que favoreceria uma classe, ou alguém, por um motivo nobre. Dworkin não admite essa desconsideração. As pessoas devem ser respeitadas em suas expectativas jurídicas e elas se formam com base nos direitos institucionais. Desse modo, na resolução dos litígios, eles prevalecem sobre eventuais direitos preferenciais que as pessoas possam alegar ter. Os direitos preferenciais, como aqueles que criam um benefício tributário a uma classe desfavorecida, apenas valem se forem devidamente institucionalizados.

$\mathrm{Na}$ última etapa deste percurso sobre a tese dos direitos de Dworkin, esclarece-se o que seriam os direitos jurídicos. Os direitos jurídicos seriam direitos institucionais especiais, isto é, decorrentes das instituições jurídicas. Portanto, neles se incluem aquilo que está prescrito na Constituição, nas leis e nos precedentes. Nesse contexto, os princípios, que são direitos jurídicos, de acordo com Dworkin, podem subjazer às regras positivas do Direito, ou estarem nelas inscritos expressamente ${ }^{175}$. Os direitos jurídicos são importantes elementos da argumentação jurídica, nos casos difíceis, e costumam gerar controvérsia quanto ao seu conteúdo, todavia, apesar de toda divergência,

175 DWORKIN, Ronald. Levando os direitos a sério,cit. pp. 164-165 
Dworkin afirma a existência de respostas certas.

\author{
A relevância deste Capítulo sobre os direitos institucionais e \\ jurídicos, como se pôde observar, decorre do fato dos casos difíceis serem \\ resolvidos com base neles, sendo, portanto, importante subsídio teórico para se \\ apresentar a tese da única resposta certa nos casos controversos.
}

\title{
II.3.4. TESE DA ÚNICA RESPOSTA CERTA NOS CASOS CONTROVERSOS
}

\section{A tese da única resposta certa nos casos difíceis defendida por}

Dworkin, desde a sua publicação, vem gerando bastante polêmica entre os diversos estudiosos do tema, especialmente, na comunidade anglo-americana ${ }^{176}$,

176 A esse respeito, menciona-se MICHAEL C. DORF, professor associado da Columbia University School of Law, o qual afirma haver uma forte crítica, na comunidade anglo-americana, a Dworkin por sua tese de uma única resposta correta nos casos difíceis: "During his long and distinguished carrer, Ronald Dworkin has championed a broad collection of claims about Anglo-American jurisprudence. Principal among these are: that there really are right aswers in hard cases (...)" (DORF, Michael C. Truth, Justice, and the American Constitution, cit., p. 134) Apenas para exemplificar, um dos críticos anglo-americanos é ROBERT LIPKIN, que refuta a tese de Dworkin, nos seguintes termos: "Dworkin explicitly uses the conception of truth. In his view, a legal proposition is true if it follows from the best constructive interpretation of the relevant legal practices. Because he believes in the concept of truth, Dworkin believes there are uniquely right answers even in hard legal cases. Although Dworkin's conception of truth is a weak conception because it follows from the best justification and not vice-versa, it still distorts his conclusion. Dworkin's use of the predicate "is true" precludes him from perceiving the relational or agent-relative character of law as integrity. It makes no sense to say that a proposition is true for me and not for you, and so Dworkin must insist on his one right answer thesis. Once Dworkin's theory is recognized as a theory of justification and not of truth, the fact that different justifications work for different people will become apparent, and his theory can be evaluated in those terms." (LIPKIN, Robert Justin. Indeterminacy, justification and truth in constitutional theory, Fordham Law Review, vol. 60,1992, pp. 630-631). Este autor parece distorcer o pensamento de Dworkin para firmar sua posição, na medida em que afirma que a teoria de Dworkin implica na ideia de que uma proposição pode ser verdadeira para uma pessoa e não ser para a outra, porque diferentes justificações funcionam de maneira diferente para as pessoas, o que parece ser uma grave distorção do pensamento do autor. Dworkin defende que a divergência, ou seja, o fato de uma pessoa achar sua posição melhor, mais justificável, que a de outra, não implica que existam "duas verdades" sobre a questão, ao contrário, defende que apenas uma delas (ou nenhuma delas, e sim uma terceira, caso ambas não apresentem a melhor justificativa para a prática jurídica) pode ser considerada verdadeira, ou a resposta correta, porque apenas uma delas pode representar " $a$ " melhor justificativa para prática. Portanto, o fato da pessoa achar sua resposta melhor, que as das demais, não significa que ela seja verdadeira, na teoria de Dworkin. Por último, destaca-se que a possibilidade de haver um empate, embora seja logicamente possível, é muito improvável na 
o que é bastante natural, tendo em vista que é popular a afirmação que as decisões judiciais não podem ser consideradas, objetivamente, verdadeiras, pois seriam produto da subjetividade do julgador ${ }^{177}$. A refutação preliminar da tese de Dworkin, em grande parte, decorre da falta de compreensão mais global do pensamento do autor, que, quando devidamente esclarecido, pode revelar algumas inconsistências das críticas a ele dirigidas.

A oposição a essa tese, de maneira geral, concentra-se nas ideias defendidas pelos céticos (ceticismo interno e externo), a qual será trabalhada em Capítulo próprio, dada a sua relevância. Neste Capítulo, procurar-se-á esclarecer em que consiste a tese da única resposta certa defendida por Dworkin e a sua consistência teórica, tendo especial atenção aos seus trabalhos mais recentes, $A$ Justiça de toga e Justice for Hedgehogs. Nesse sentido, não se focará em obras mais antigas do autor (Uma questão de princípio e Levando os direitos a sério), as quais trabalham expressamente o tema em capítulos específicos ${ }^{178}$, apenas mencionando-as quando se fizer necessário. O propósito é avançar em um caminho mais profundo dessa tese, com enfoque no que foi apresentado nas suas obras mais recentes, de modo que sua consistência teórica reste demonstrada com maior acuidade e atualidade.

complexidade da prática jurídica contemporânea.

177 Com relação a essa polêmica sobre a objetividade das decisões judicial, menciona-se ROBERT HANSON, o qual afirma que é comum haver críticas sobre essa objetividade, sendo, nesse sentido, usual a afirmação de que os juízes estão apenas aplicando suas preferências pessoais para resolver a questão controversa. Se esta crítica se comprovasse, o que o autor defende não ocorrer, implicaria em uma mácula à neutralidade do Poder Judiciário, afirmada na Constituição norte-americana no art. III: "It seems like every time a judge decides an important well-publicized case, those with access to the media who disagree immediately criticize the decision. A common approach for these critics is to show how judge's decison-making process was not objective; that is, that the decision was influences by judge's personal characteristics, such as political persuasion, race, ideology, gender, or economic background. (...) Despite the potential asymmetry in this type of critique of judge's decisions, their effect is to strike at the heart of the United States system of government: the independent, and formally neutral, judiciary" HANSON, Robert. Objective decision making in Lonergan and Dworkin, Boston College Law Review, vol. 44, 2003, pp. 825-826

178 Capítulos 13 e 5, respectivamente, das obras Levando os direitos a sério e Uma questão de princípio 
Com esse propósito, a condução deste Capítulo desenvolver-se-á em etapas, as quais (i) se iniciam nas indagações sobre os meios para se chegar a uma verdade moral; (ii) seguem com um debate metodológico sobre os diferentes tipos de conceito e a forma como a interpretação pode ser considerada verdadeira, nesses termos; e (iii) prosseguem com a questão da responsabilidade moral, importante elemento para se chegar na resposta certa, como se procurará esclarecer ao longo deste Capítulo.

A importância de se esclarecer os pontos acima elencados, especialmente, no que se refere aos pontos (i) e (iii), e a sua relevância para a resposta certa nos casos difíceis, cujas indagações são de natureza jurídica, é decorrente da já amplamente demonstrada moralidade do Direito, evidenciada ao longo deste trabalho em múltiplas oportunidades. Para ilustrar essa forte conexão, Dworkin ousa afirmar que "o argumento jurídico é um argumento típica e completamente moral" e complementa afirmando que "os juristas devem decidir qual desses conjuntos concorrentes de princípios oferece a justificação da prática jurídica como um todo, isto é, que seja mais peremptória em termos morais" ${ }^{, 179}$. Portanto, a questão do julgamento dos casos difíceis e a necessidade de se recorrer a expedientes morais para se construir a decisão judicial, na teoria de Dworkin, impõe o desafio de saber se a moralidade a que se socorre o julgador, para construir seu argumento jurídico, corresponde à verdade. Feito este comentário para situar as questões sem apenas lançá-las, imprudentemente, passa-se a análise das etapas acima elencadas.

Quanto à primeira etapa - os meios para se chegar a uma verdade moral - Dworkin, inicialmente, esclarece que essa indagação deve ser respondida pela própria moral e não se deve buscar algo externo a ela como ponto de referência para analisar a falsidade, ou a veracidade de uma proposição

179 DWORKIN, Ronald. A justiça de toga, cit., p. 205 
dessa ordem, defendendo a independência dos campos do conhecimento ${ }^{180}$, que operariam com regras próprias internas a eles. Nesse sentido, Dworkin rejeita ao que denomina ceticismo arquimediano, que busca essa perspectiva externa (metafísica), para avaliar a veracidade, ou falsidade, de uma proposição moral, embora reconheça que esse tipo de ceticismo é bastante popular entre os filósofos. ${ }^{181}$

Antes de prosseguir quanto aos meios de se chegar a uma verdade moral, faz necessário esclarecer que, para Dworkin, o que importa nesse debate, não é discutir a possibilidade de haver um julgamento moral verdadeiro, porque ele toma essa possibilidade como premissa, mas saber qual deles é o verdadeiro e, nesse sentido, elabora seus argumentos sobre o que deve ser levado em consideração para se chegar a ele.

Em primeiro lugar, quanto aos meios para se chegar a um julgamento moral verdadeiro, isto é, saber quais as proposições morais que podem ser ditas verdadeiras, ele faz uma importante distinção, qual seja, ele as diferencia das afirmações que são verdadeiras na física. Esclarece que, no mundo físico, as proposições são verdadeiras se elas corresponderem ao real estado físico dos objetos de estudo (fatos brutos). Não importa, a esse respeito, o quanto a pessoa é capaz de argumentar sobre a possibilidade de uma dada proposição ser verdadeira, no mundo físico, se ela não corresponder à realidade

\footnotetext{
180 “(...) morality and other departments of value are philosophically independent. Answers to large question about moral truth and knowledge must be sought within those departments, not outside them." - Tradução livre: “(...) moralidade e outros campos do valor são filosoficamente independentes. Respostas a uma grande questão sobre verdade moral e conhecimento têm de ser buscadas dentro de seus próprios campos, e não fora deles." DWORKIN, Ronald. Justice for hedgehogs, cit., p. 24

181 "That is not a popular view among philosophers. They think what I quote earlier: that the most fundamental questions about morality are not themselves moral, but rather metaphysical, questions." Tradução livre: "Isto não é uma visão popular entre os filósofos. Eles pensam que o que eu afirmei antes: que as questões mais fundamentais sobre moralidade não são elas mesmas morais, mas questões metafísicas.” DWORKIN, Ronald. Justice for hedgehogs, cit., p. 25
} 
do fato bruto, ela não será verdadeira por mais que tenha bons argumentos para afirmar aquela posição. A condição de veracidade não depende dos argumentos, mas de uma adequação perfeita à realidade que se afigura. Nesse sentido, Dworkin esclarece que:

"Afirmações sobre o mundo físico são verdadeiras se corresponderem ao real estado do mundo físico - seus conteúdos, partículas, e disposições. Nós podemos evidenciar muito comumente através da observação dos instrumentos científicos - sobre qual é o real estado do mundo físico. Esta evidência, nós podemos dizer, nos provê de um argumento para a nossa opinião sobre o mundo físico. Mas é o mundo físico por ele mesmo, a forma como as partículas realmente se aceleram, não a evidência que podemos afirmar, que determina se nossa opinião é verdadeira ou falsa. Nossa evidência pode ser mais poderosa, mas nossa conclusão restar errada, porque, como uma questão de fato bruto, o mundo não é da forma que achamos que provamos que ele é." 182

Quanto aos julgamentos morais, Dworkin afirma que não se pode aplicar o mesmo raciocínio, uma vez que, por sua natureza, os julgamentos morais não são julgamentos sobre fatos brutos do mundo físico. Nesse sentido, o filósofo exemplifica afirmando que não se consegue provar com base em fatos brutos que torturar um bebê por diversão é errado; ou que torturar um prisioneiro de guerra para obter informações importantes sobre o inimigo é a atitude certa, dentre outros casos que aqui se poderia mencionar. Trata-se de julgamentos morais, cuja veracidade, ou falsidade, não se encontram em fatos brutos, já postos e esperando ser descortinados da maneira correta ${ }^{183}$. Os

182 Tradução livre do trecho: "Statements about the physical world are made true by the actual state of the physical world - its continents, quarks, and disposition. We can have evidence - very often through observation of scientific instruments - about what the actual state of the physical world is. That evidence, we might say, provides an argument for our opinions about the physical world. But it is the physical world itself, the way the quarks actually spin, not the evidence we can assemble, that determines whether our opinion are actually true or false. Our evidence might be ever so powerful, but our conclusion nevertheless wrong, because, as a matter of brute fact, the world is not the way we think we have proved it is." DWORKIN, Ronald. Justice for hedgehogs, cit., pp. 28-29

183 A esse respeito, STEPHEN GUEST esclarece que Dworkin, alinhado a David Hume, diferencia a ciência dos valores, enuncia que a ciência depende de uma relação de causalidade para provar a 
julgamentos morais dependem de outras condições, que são também morais, para serem considerados verdadeiros.

Quanto às condições, Dworkin esclarece que os julgamentos morais são considerados verdadeiros quando há argumentos morais adequados, que são capazes de apresentar a melhor justificação nesse contexto de moralidade. ${ }^{184}$

Para compreender esta questão, que é o cerne deste Capítulo, é necessário fazer alguns esclarecimentos de ordem metodológica, os quais serão subsídios necessários à sua correta compreensão, na medida em que, como já se introduziu, há uma grande distinção entre a forma de verificação da veracidade das proposições morais e físicas, em virtude da forma como são apreendidos estes conceitos. Nesse sentido, irá se retomar a tipologia conceitual criada por Dworkin, já apresentada no Capítulo II.2, sobre a teoria da decisão judicial, e, posteriormente, na terceira etapa, referente à responsabilidade moral, irá se demonstrar em que consiste a adequação e justificação, já referidas enquanto condições necessárias para se considerar uma proposição moral verdadeira. ${ }^{185}$

Quanto à metodologia dos conceitos, Dworkin esclarece que há três tipos centrais de conceitos ${ }^{186}$, quais sejam, (i) os conceitos baseados em critérios; (ii) os conceitos de espécies naturais; e (iii) conceitos interpretativos.

veracidade de suas proposições, enquanto, os valores não carecem dessa relação de causalidade. "In short, Dworkin thinks, like Hume, that science and value are different and there are no causal accounts of truth in value (...) For him, truth represents success independently within either domain enquiry. Value is best seen as an integral unity - no conflict - of true propositions (just as scientists say of science). His theory of interpretation is that our value concepts are inherently controversial and we must make "best sense" of them; in the case of ethical and moral value this means making the best ethical and moral sense." GUEST, Stephen. Ronald Dworkin, cit., p. 11

184 DWORKIN, Ronald. Justice for hedgehogs, cit., p. 37

185 Importa ressaltar, nesse sentido, que já foram mencionadas as dimensões da adequação e justificação na formação do conceito de Direito como integridade, no Capítulo II.1. No presente Capítulo, far-seão complementações dessas dimensões já previamente trabalhadas.

186 DWORKIN, Ronald. A justiça de toga, cit., pp. 15-20 
Nestes últimos, encontram-se os que interessam à moral e, portanto, também ao Direito.

Em suma, como já foi tratada a diferença entre estes conceitos no Capítulo II.2, rememora-se apenas o que segue: (i) os conceitos baseados em critérios formam-se a partir do que se convencionou, enquanto critério de sua definição, em um dado contexto; (ii) os conceitos de espécies naturais baseiamse na matéria bruta, cada pessoa considera-os de acordo com seu interesse e nível cultural, mas isso não modifica a sua natureza; e, por fim, (iii) os conceitos interpretativos, que se fundam no compartilhamento de certas práticas na comunidade política, as quais carecem ser interpretadas para constituí-los. Por ora, a respeito dessa tipologia, salienta-se que não se pretende retomar aqui em todos os termos a discussão já empreendida no Capítulo II.2, pretende-se aprofundar as considerações naquilo que for pertinente ao tema em discussão neste Capítulo.

Quanto aos conceitos interpretativos ${ }^{187}$, destaca-se que eles diferem especialmente dos demais por envolver certo tipo de acordo diferente. Os demais conceitos, em geral, podem ser "testados" de maneira mais simplória, por exemplo, quando se afirma que um triângulo de três lados iguais, objeto da análise, é equilátero (conceito baseado em critérios), ou que a água é composta por duas moléculas de hidrogênio e uma de oxigênio (conceito de espécies naturais). Dworkin esclarece que é, em certa medida, simples atestar a veracidade destes conceitos. Por sua vez, os conceitos interpretativos são marcados pela divergência entre seus intérpretes, embora para formá-los estes partam de um substrato comum de práticas compartilhadas (por exemplo, os

187 “ $(\ldots)$ the kind of agreement that is required in the case of an interpretative concept is very different: it is not agreement on a decision procedure as a decisive test for instances. On the contrary, sharing an interpretative concept is consistent with very great and entirely intractable differences of opinion about instances." DWORKIN, Ronald. Justice for hedgehogs, cit., p. 161 
intérpretes concordam sobre a origem histórica da Democracia americana, os principais marcos institucionais dela, todavia, tendem a divergir ao discutirem se uma prática como a ação afirmativa é democrática, ou antidemocrática). Nesse sentindo, pode-se afirmar que não há um teste simples para verificar se uma prática é justa, igualitária, ou democrática, todavia, isso não impede que se afirme o conceito de justiça, igualdade, Democracia etc.

Os membros da comunidade política, para Dworkin, assumem de antemão a possibilidade de divergência entre si sobre a melhor interpretação dos conceitos interpretativos, pois este é um traço que lhes é característico. Eles não divergem quanto às práticas compartilhadas, mas quanto ao papel delas na formação do conceito interpretativo, privilegiando um, ou outro, de seus aspectos, o que leva, por conseguinte, a diferentes concepções do conceito. ${ }^{188}$ Em outras palavras, os conceitos interpretativos, nesse sentido, podem ser definidos pelos seus intérpretes, embora, esta definição seja inevitavelmente controversa. ${ }^{189}$

$\mathrm{Na}$ teoria formulada por Dworkin, para saber qual destes conceitos formulados melhor atende à prática compartilhada, o intérprete deve recorrer a uma rede mais ampla de valores ${ }^{190}$, que irão sustentar a sua concepção face às demais interpretações. Busca-se, portanto, nessa empreitada uma análise,

\footnotetext{
188 "Because we share the interpretative concept of justice; we can recognize the theories of a great variety of political philosophers as competing conceptions of that concept. Utilitarian and others consequentialist philosophers interpret the practices in which claims of justice figure by supposing those practices to aim at the general happiness or some other desirable goal. Political philosophers in the kantian tradition offer very different interpretations." DWORKIN, Ronald. Justice for hedgehogs, cit., p. 162

189 "I should add that because moral concepts are interpretative it is a mistake to say that they cannot be defined. Moral and political philosophy, as we shall see, is in large part an effort to define them. We should rather say that because any definition of a moral concept is a piece of moral interpretation, any helpful definition will inevitably be controversial" DWORKIN, Ronald. Justice for hedgehogs, cit., p. 170

190 Neste ponto, remete o leitor a concepção de valores integrados explanada no Capítulo II.2. A teoria da decisão judicial de Ronald Dworkin
} 
integrada, holística, para que o intérprete, diante de um dado caso prático, possa chegar à resposta correta quanto à aplicação daquele conceito.

A melhor maneira de chegar à resposta verdadeira é agindo com responsabilidade moral. Com esse propósito, o intérprete deverá procurar argumentos adequados, dentro dessa perspectiva de pluralidade de valores da prática jurídica, e, em uma etapa seguinte, verificar quais deles melhor a justifica, nesta visão holística dela, em que tudo está entrelaçado e conectado pela força da integridade. Se o intérprete agir dessa forma, estará agindo com responsabilidade moral e, para Dworkin, como já foi mencionado, esta é a melhor forma de se aproximar da resposta verdadeira:

“(...) o raciocínio interpretativo requerido para se agir com responsabilidade moral é nossa melhor esperança para alcançar a verdade moral."191

Inicia-se, então, a exposição da terceira etapa (iii), a qual abordará a questão da responsabilidade moral e sua importância na tarefa do intérprete que pretende alcançar a verdade moral.

Dworkin afirma que pessoas moralmente responsáveis podem até não atingir a verdade, mas certamente a procuram em suas ações ${ }^{192}$. Procurar a verdade, nesse sentido de agir com responsabilidade moral, significa buscar razões adequadas para justificar seu julgamento, de modo que se possa afirmar que a resposta encontrada é a verdadeira. Ou seja, agir com responsabilidade moral é procurar as razões das afirmações morais que se faz, e não apenas afirmá-las enquanto tal. Dworkin esclarece que as razões são necessárias para

191 Tradução livre do trecho: “(...) I emphasized the distinction between moral truth and moral responsibility. But I also said that the interpretative reasoning required for moral responsibility is our best hope for achieving moral truth.” DWORKIN, Ronald. Justice for hedgehogs, cit., pp. 179-180

192 "Morally responsible people may not achieve truth, but they seek it." DWORKIN, Ronald. Justice for hedgehogs, cit., p. 113 
atribuir a qualidade de verdadeiro a um julgamento moral:

"É sempre adequado perguntar porque a moralidade requer o que nós dizemos que ela requer, nesse sentido, nunca será adequado dizer: ela apenas requer. Muito frequentemente, claro, nós não podemos dizer muito mais que isso. Nos poderíamos dizer: 'a tortura é errada, e isso é tudo que se tem a dizer a respeitó. Mas isto revela apenas impaciência ou falta de imaginação: isso não expressa responsabilidade moral, mas seu oposto." 193

Alguém que tem compromisso com a verdade moral, isto é, que age de maneira responsável, não pode responder simplesmente sem qualquer fundamentação, quando confrontado sobre a veracidade da afirmação que faz. $\mathrm{O}$ fundamento, a razão que sustenta a veracidade de um julgamento moral, é apresentado por Dworkin dentro de uma circularidade de valores. Esclarece-se: um julgamento moral é verdadeiro se fundar-se em outros julgamentos morais, que também podem ser considerados verdadeiros:

"A verdade de qualquer julgamento moral consiste na verdade de um número indefinido de outros julgamentos morais. E sua verdade provê parte do que constitui a verdade de cada um deles. Não há hierarquia de princípios morais construídos em uma fundação axiológica (...)"194

Dworkin, portanto, considera que o processo interpretativo não deve considerar os valores como se eles fossem independentes, ou em alguns casos, pudessem até concorrer entre si, esta visão não tem guarida na sua teoria,

193 Tradução livre do seguinte trecho: "It is always appropriate to ask why morality requires what we say it does, and never appropriate to say: it just does. Very often, of course, we cannot say much more than that. We might say: 'torture is just wrong, and that's all there is to it.' But this is only impatience or lack of imagination: it expresses not responsibility but its opposite." DWORKIN, Ronald. Justice for hedgehogs, cit., p. 115

194 Tradução livre do seguinte trecho: "The truth of any true moral judgment consists in the truth of an indefinite number of other moral judgments. And its truth provides part of what constitutes the truth of any of those others. There is no hierarchy of moral principles built on axiomatic foundations (...)" DWORKIN, Ronald. Justice for hedgehogs, cit., p.117 
que defende a interpretação holística dos valores, em sua pluralidade, por uma perspectiva não fragmentada destes, mas unificadora. ${ }^{195}$

Por essa perspectiva, o julgamento moral para ser verdadeiro precisa mostrar-se sustentável face aos demais, deve mostrar-se compatível a eles. Essa compatibilidade (adequação), na teoria de Dworkin, pode ser representada pela ideia de que o julgamento moral concebido pode ser aplicado, em outras situações, melhor do que outros julgamentos que se poderiam conceber, ou seja, ele representa melhor o conjunto desses julgamentos (por exemplo, se for uma decisão judicial sobre um caso difícil - dependente de um julgamento moral nestes termos -, esse conjunto difuso seria composto pelo registro institucional, como as leis e decisões dos Tribunais, e pela moralidade política da comunidade). Nessa etapa, ainda assim, seria possível encontrar mais de um julgamento moral, que se mostraria adequado a esse conjunto, todavia, apenas um representaria uma justificativa melhor à moralidade daquela comunidade política, e, portanto, seria a melhor alternativa para a continuidade de sua história, escrita pelas mãos dos intérpretes do passado, do presente e cujo texto será apresentado aos intérpretes do futuro para que prossigam a jornada ${ }^{196}$ :

"Argumento que há duas dimensões ao longo das quais se deve
julgar se uma teoria fornece a melhor justificação dos dados
jurídicos disponíveis: a dimensão da adequação e a dimensão
da moralidade política. A dimensão da adequação supõe que
uma teoria política é pro tanto uma justificativa melhor que
outra se, grosso modo, alguém que a sustentasse pudesse, a
serviço dela, aplicar mais daquilo que está estabelecido do que
alguém que sustentasse outra. (...) A segunda dimensão - a
dimensão da moralidade política - supõe que, se duas
justificativas oferecem uma adequação igualmente boa aos

195 "We reinterpret our concepts to resolve our dilemma: the direction of our thought is toward unity, not fragmentation. However we decide, we have taken a step toward a more integrated understanding of our moral responsibilities." DWORKIN, Ronald. Justice for hedgehogs, cit., p. 119

${ }^{196}$ Ideia do romance em cadeia mencionado no Capítulo II.1. O Conceito de Direito para Ronald Dworkin 
dados jurídicos, uma delas, não obstante, oferece uma justificativa melhor que a outra se for superior enquanto teoria política ou moral; isto é, se apreende melhor os direitos que as pessoas realmente têm. " 197

Os elementos a que o intérprete recorre, neste processo, devem ser também considerados verdadeiros ${ }^{198}$, no sentido de que não seria plausível, por exemplo, recorrer a algo que, sabidamente, não é reconhecido enquanto um valor da comunidade política. Nisto reside a circularidade da teoria proposta por Dworkin, em que os elementos se auto-referenciam e atribuem entre si a veracidade de si mesmos, não se procura algo externo a eles, ou um critério outro que testaria sua veracidade. A verdade moral deve ser buscada na própria moral. Assim como, em um caso difícil, o intérprete deve recorrer à prática jurídica e não a um livro sagrado, não reconhecido por esta prática, para saber se encontrou a resposta correta.

A melhor forma de se obter a resposta correta é com este agir responsável do intérprete, que é cuidadoso, que leva em consideração na construção do seu juízo a ideia de adequação e justificação de sua resposta dentro da própria área que está em avaliação. Todavia, a teoria de Dworkin não apresenta e, diga-se de passagem, nem se propõe a apresentar, um teste que daria certeza ao intérprete de que ele estaria diante da resposta certa, a resposta verdadeira, até porque, como já se esclareceu, metodologicamente, nos conceitos interpretativos, este teste não existiria.

Dworkin admite que há a possibilidade lógica de haver mais de uma resposta correta, isto é, um empate entre duas posições equipotentes,

197 DWORKIN, Ronald. Uma questão de princípio,cit., p. 213

198 “Afirmo que uma proposição de direito é verdadeira se decorrer de princípios de moralidade pessoal e política que ofereçam a melhor interpretação das outras proposições de direito geralmente tratadas como verdadeiras na prática jurídica contemporânea." DWORKIN, Ronald. A justiça de toga, cit. , p. 22 
todavia, como o sistema jurídico contemporâneo é complexo, oferecendo muitos elementos a ser considerados pelo intérprete, seria muitíssimo improvável que isso acontecesse, nesse sentido, menciona-se que:

“(...) em um sistema jurídico complexo e abrangente é improvável que duas teses difiram a ponto de exigir respostas diferentes em algum caso e, ainda assim, adequar-se bem ao conteúdo jurídico relevante." 199

"Esta instrução não nega a possibilidade teórica de um empate, mas pressupõe que, dada a complexidade do material jurídico existente, os juízes irão concluir - depois de uma longa e exaustiva reflexão - que, pesados todos os prós e contras, uma ou outra das partes detém a melhor argumentação para o caso." $" 200$

Mesmo havendo essa possibilidade lógica de haver um empate, considerando que ela é remota, o intérprete deve envidar todos os seus esforços para encontrar a resposta certa. Além disso, reitera-se que a melhor forma de se chegar à resposta correta, ou verdadeira, na teoria de Dworkin, é agindo com responsabilidade moral, ${ }^{201}$ alguns poderiam discutir se seria, neste contexto, necessário falar em resposta correta, ou verdadeira, ou poder-se-ia apenas dizer que os intérpretes devem agir com responsabilidade ${ }^{202}$, seria mais simples e levantaria menos críticas enfurecidas. Dworkin, todavia, defende o seu empreendimento. Afirma que insistir na ideia de verdade traz virtudes positivas, dentre elas, o fato de que a busca por esta verdade manteria a profundidade do desafio filosófico que se propõe nestas difíceis questões.

199 DWORKIN, Ronald. Uma questão de princípio, cit., p. 215

200 DWORKIN, Ronald. Levando os direitos a sério, cit., p. 440

201 "(...) the interpretative reasoning required for moral responsibility is our best hope for achieving moral truth" DWORKIN, Ronald. Justice for hedgehogs, cit., p. 180

202 ROBERT LIPKIN defende que a ideia de verdade é, absolutamente, desnecessária para o Direito, prefere falar apenas em justificação: "A philosophical conception of truth as correspondence, or any strong conception of truth purporting to explain why we hold the beliefs we do, is unlikely and unnecessary in constitutional theory. Such a strong conception of truth is unlikely because the best theorists have been unable to devise such a notion of truth. Moreover, it is unnecessary because constitutional theory has operated well without such a notion of truth." LIPKIN, Robert Justin. Indeterminacy, Justification and Truth...., cit., p. 628 
Nesse esteio, com intuito de aprofundar o debate sobre a tese da única resposta certa (resposta verdadeira), cujas balizas centrais do pensamento de Dworkin, aqui foram apresentadas, é necessário dar um último passo, neste processo de esclarecimento, a crítica feita pelos céticos à sua tese.

\section{II.3.4.1. CRÍTICA DOS CÉTICOS (CETICISMO INTERNO E EXTERNO)}

Inicialmente, é importante distinguir dois tipos centrais de ceticismo, com os quais se irá trabalhar neste Capítulo: o ceticismo interior ${ }^{203} \mathrm{e}$ o ceticismo exterior $^{204}$. Essas duas formas de ceticismo, embora cada uma adote uma estratégia diferente, contestam a ideia de uma única resposta certa defendida por Dworkin. ${ }^{205}$ Essa contestação pode ser forte o suficiente para muitos rejeitarem a tese de Dworkin, especialmente, considerando que o autor não oferece um teste para averiguar a veracidade dos juízos interpretativos e segue uma linha que exige do intérprete um esforço hercúleo de conhecimento

203 Com relação ao ceticismo interior, ver: JOSEPH RAZ (Incommensurability, In: The Morality of freedom, New York: Oxford University Press, 1984, pp. 321-366); MARTHA MinOW e JOSEPH W. SINGER (In favor of foxes: pluralism as a fact and aid to the pursuit of justice, In: Symposium Justice for Hedgehogs: conference on Ronald Dworkin forthcoming book (special issue), Boston University Law Review, vol. 90, n. ${ }^{\circ}$ 2, abril, 2010); e LEO KATZ (Incommensurable choices and the problem of moral ignorance, University of Pennsylvania Law Review, vol. 146, n. ${ }^{\circ}$ 5, junho, 1998, pp. 14651485)

204 Com relação ao ceticismo exterior, ver: SIMON BLACKBURN (Spreading the word: grounding in the philosophy of language. Oxford University Press, 1984, pp. 167-71); ALLAN GIBBARD (Wise choices, apt feelings, Harvard University Press, 1992, pp. 126-151); R. M. HARE (The language of morals, Oxford University Press, 1952, pp. 163-179); RICHARD JOYCE (The Myth of Morality, Cambridge University Press, 2001, pp. 53-79); J. L. MACKIE (Ethics: inventing right and wrong, New York: Penguin, 1977, pp. 15-49)

205 Esclarece-se que os advogados anglo-americanos tendem a ser céticos sobre a ideia de uma única reposta certa às questões jurídicas. A esse respeito, menciona-se PAUL H. BRIETZKE: "Dworkin's treatment of skepticism offers too few incentives for the skeptics to join in his enterprise. He does admit that Anglo-American lawyers are skeptical about the possibility of right answers. But some other theorists would add their skepticism about the relevance of some or many of the questions in legal philosophy, questions like those Dworkin says judges and legislators should and actually do ask." (g.n.) BRIETZKE, Paul H. Dworkin today, Valparaiso University Law Review, vol. $21, n^{\circ} .2,1987$, p. 332 
de sua prática (quanto mais conhecer a sua prática, tiver um bom repertório, mais se aproximará de um juízo correto de adequação), e, também, exigirá do intérprete, na etapa seguinte, um processo reflexivo para saber qual julgamento melhor justifica aquela prática ${ }^{206}$. Nesse sentido, é possível afirmar que o fato de Dworkin não oferecer uma fórmula mágica das respostas corretas facilita a adesão às ideias céticas, daqueles que são mais pragmáticos e têm menos paciência para esse tipo de abstração empreendida pela teoria de Dworkin. ${ }^{207}$

O ceticismo interior não encontra em um elemento, ou teste, externo a impossibilidade de haver um juízo interpretativo correto. Ao contrário, por meio da própria interpretação, nega a possibilidade de afirmar que uma posição é mais correta do que outra. Ou seja, acredita ser possível haver posições equipotentes, a permitir um empate, que inviabilizaria a proposta de uma única resposta correta em matéria interpretativa. Enquanto, o ceticismo exterior adota a estratégia oposta, recorre a um elemento exterior. Isto é, não entra no mérito das interpretações feitas, prefere defender que nenhuma delas pode ser dita verdadeira, na medida em que não há um teste externo que lhes dê essa condição. ${ }^{208}$ Aprofunda-se, adiante, cada uma dessas ideias.

Como a crítica do cético interno, para Dworkin, apresenta maior

\footnotetext{
206 "A tese da resposta certa, conforme se procurará demonstrar, está na base de uma concepção interpretativa da verdade e da objetividade, segundo a qual afirmar a objetividade de uma proposição significa reconhecer que ela está justificada pelos melhores argumentos disponíveis." MACEDO JUNIOR, Ronaldo Porto. Do xadrez à cortesia: Dworkin e a teoria do direito contemporânea, cit., p. 33

207 “Apresentei esta caracterização geral e muito abstrata da interpretação: ela tem por finalidade apresentar em sua melhor luz o objeto ou à prática a serem interpretados. (...) Portanto, minha descrição abstrata do objetivo mais geral da interpretação pode muito bem reforçar, para muitos leitores, a tese cética de que é um erro filosófico supor que as interpretações podem ser certas ou erradas, verdadeiras ou falsas." DWORKIN, Ronald. $O$ império do direito, cit., p. 96

208 "Sua teoria é, na verdade, uma teoria de segundo grau sobre a posição ou a classificação filosóficas dessas afirmações. Ele insiste em que elas não são descrições que possam ser comprovadas ou testadas, como na física: nega que os valores estéticos ou morais possam ser parte daquilo que chama (em uma das metáforas perturbadoras que parecem cruciais a qualquer afirmação de seus pontos de vista) de 'fundamentos' do universo." DWORKIN, Ronald. O império do direito, cit., p. 98
} 
envergadura por partir de uma perspectiva interna à própria interpretação, iniciase a análise com os céticos externos.

Os céticos externos, por tomarem a possibilidade de verdade apenas por um critério externo ${ }^{209}$, que permitiria um teste descritivo da proposição afirmada (como ocorre com as proposições da física atinentes aos fatos brutos, em que se apresentam as evidências), limitam o seu debate para os juízos interpretativos, na medida em que por estes implicarem em um raciocínio diferenciado, não atrelado ao mundo físico, não seria possível evidenciar a sua veracidade nestes termos.

Além disso, pode-se afirmar que os céticos externos não vislumbram, metodologicamente, a diferença dos conceitos interpretativos com relação aos conceitos baseados em critérios, ou os de espécies naturais e, por isso, insistem na ideia equivocada de que a forma de se atingir a veracidade deveria ser a mesma para todos os tipos de conceito. Como, para os juízos interpretativos, não se consegue "testar" sua veracidade dessa forma neutra, como eles pretendem fazer, sem incorrer em uma nova interpretação, a um novo juízo moral, os céticos exteriores assumem que essas interpretações, esses juízos morais, são meras opiniões, que não podem arrogar para si o atributo de verdade.

Considerando que os céticos exteriores não concordam com o pressuposto metodológico de Dworkin para formação dos conceitos interpretativos, não se pode ter uma discussão franca e honesta com eles sobre a veracidade e falsidade desses juízos, por isso, não irá se alongar o debate com os

\footnotetext{
209 “(...) the most sophisticated external skeptics rely, as I said earlier, on metaphysical theses about the kind of entities the universe contains. They assume that these metaphysical theses are external statements abut morality rather than internal judgments of morality. (...) external skepticism is supposedly Archimedean: it stands above morality and judges from the outside." DWORKIN, Ronald. Justice for hedgehogs, cit., p. 32
} 
céticos exteriores sobre a tese da única resposta certa de Dworkin, apenas deixando registradas as considerações acima elencadas.

Os céticos interiores, por outro lado, oferecem um desafio mais perigoso. Explica-se: eles aceitam que os conceitos interpretativos são formados por interpretações, e, por isso, diferentemente dos céticos exteriores, não defendem que se deve atestar sua veracidade buscando um critério a eles externo. Então, pode-se dizer que compartilham do pressuposto metodológico de Dworkin, acreditam, que as interpretações não são neutras e tampouco teriam esse papel de descrever fatos sujeitos à evidência no mundo exterior. Todavia, discordam do autor ao afirmar que não é possível confrontar a veracidade de uma interpretação em face de outra, que também se mostre adequada. Defendem a existência, portanto, de interpretações equipotentes, inviabilizadoras da tese de Dworkin de uma única resposta certa nos casos difíceis.

Quanto à possibilidade do empate, defendida pelo ceticismo interno, Dworkin faz as seguintes considerações. Ele afirma que o juízo de empate, ou seja, que permitiria ao intérprete afirmar que nenhuma das interpretações é superior à outra, é também um juízo. Porém, o cético interno assume que ele seja o juízo verdadeiro, toma para si, como resposta correta, a afirmação de que não há resposta correta para questão ${ }^{210}$. Dworkin exemplifica este ponto mencionando uma escala de posições, em que uma das posições está à esquerda, a outra a ela oposta está à direita e, cujo empate, está no meio. $\mathrm{O}$ intérprete pode defender a posição da esquerda e apresentar argumentos para

\footnotetext{
210 “O juízo de empate é da mesma natureza daquele segundo o qual uma das proposições contrárias é verdadeira e a outra, falsa. (...) O juízo de empate é, porém, um juízo positivo que tem a mesma natureza dos outros dois. Compete com eles e tem exatamente os mesmos pressupostos epistemológicos ou ontológicos (quaisquer que possam ser). Podemos dizer que o terceiro juízo é um juízo de que 'não há reposta correta' se com isto queremos dizer apenas que nenhuma das outras duas respostas disponíveis é correta; mas o terceiro juízo é um juízo com pretensão de ser a resposta correta.” DWORKIN, Ronald. Levando os direitos a sério, cit., pp. 437-438
} 
ela; outro poderia defender ferrenhamente a da direita, também, apresentando bons argumentos para a sua posição; e o cético interno, em face desta discussão, dirá que nenhuma das posições pode ser melhor do que a outra, que são interpretações equipotentes do caso em questão, e, portanto, o seu juízo é ficar no meio da escala, declarando o empate das posições. Dworkin defende que esta suspensão de juízo do cético interno, também, é assumir uma posição, sendo, a partir disso, um juízo como os da esquerda e os da direita. O cético interno optou por estar no meio e não em seus extremos, ou em alguma das escalas graduais da esquerda, ou da direita. Portanto, os céticos internos falham nesse sentido, pois seu juízo é tão falível quanto os demais por se tratar, também, de um juízo ${ }^{211}$.

Indo além, aplicando-se de maneira mais prática o que foi dito, pode-se dizer que, quando se deve decidir algo como uma controvérsia judicial, não é admissível ao juiz simplesmente não decidir, falar que ambas as partes têm bons argumentos e, por isso, nenhuma tem direito ao ganho de causa. $\mathrm{O}$ argumento cético pode ser interessante, enquanto uma posição acadêmica, mas não enquanto uma posição de grande serventia para orientar a vida prática, que exige a todo tempo tomadas de decisão. Dworkin, ao menos, oferece uma teoria que permite as pessoas decidirem, tomarem partido de uma, ou outra, posição colocadas sob análise, e, mais que isso, impõe a elas o dever de agir com

211 “(...) a resposta chamada de 'não há resposta correta', enquanto juízo no âmbito do empreendimento, é um juízo da mesma natureza que qualquer uma das outras respostas disponíveis e igualmente falível. Não se trata de uma resposta residual nem de uma resposta por omissão, que é automaticamente verdadeira sempre que não se disponha de um argumento convincente para qualquer outra resposta ou sempre que houver bons argumentos a favor das outras duas respostas." (DWORKIN, Ronald. Levando os direitos a sério, cit., pp. 438-439); "The critics do not pause to consider whether they themselves have any substantive arguments for their equally substantive position, and, if they do, whether these might not also be ridiculed as vague or unpersuasive or as resting on even bare assertions in the same way. (...) The rest of us must do the best we can: we must choose among all the substantive views on offer by asking which strikes us, after reflection and due thought, as more plausible than the others. And if none does, we must then settle for the true default view, which is not indeterminacy but uncertainty." (DWORKIN, Ronald. Justice for hedgehogs, cit., pp. 95-96) 
responsabilidade, na busca da resposta certa. Um cético interno, investido da judicatura, ao considerar que as posições das partes sub judice são equipotentes, teria que apelar, talvez, para um sorteio, já que seria obrigado, de qualquer forma, a decidir. Os céticos internos, portanto, não oferecem uma possibilidade de agir responsável para o intérprete, o que não é de forma alguma desejável em uma teoria da decisão judicial.

Por fim, apenas pontua-se que o empate entre duas proposições equipotentes, embora seja logicamente possível para Dworkin, como já foi esclarecido no Capítulo supra, não é plausível em uma comunidade política complexa, que fornece aos intérpretes elementos suficientes para afirmar que uma posição é melhor do que outra, que permite a eles encontrar com responsabilidade uma interpretação que melhor justifique esta prática, e que, portanto, pode ser considerada como a verdadeira, a única correta. A teoria de Dworkin não impõe ao intérprete a arrogância de deter a verdade, até porque a qualquer momento, pode-se encontrar uma interpretação, que melhor justifique a prática, a qual o intérprete ainda não havia considerado em seu juízo. Todavia, em que pese a possibilidade de erro, que se admite de antemão, incentiva o intérprete a buscar a verdade, pois somente assim poderá agir com responsabilidade, o que, como já foi mencionado, é muito relevante para aqueles que desempenham funções institucionais, como os juízes. 


\section{LEGITIMIDADE}

Realizada a análise das questões atinentes à decisão judicial, passa-se ao problema da legitimidade destas nos casos difíceis. A análise a ser aqui empreendida, relativa à questão da legitimidade, perpassa por alguns pontos centrais: (i) a concepção que se tem do papel definido a ser desempenhado pelos juízes no Estado de Direito; (ii) a possibilidade de coerção com o uso legítimo da força estatal para fazer cumprir a decisão sobre um caso controverso entre as partes; (iii) a suposta violação da Democracia, com a implementação da teoria da decisão judicial proposta por Dworkin; e, por fim, (iv) a legitimidade e os modelos de comunidade política, que a amparam. Estes pontos mencionados, como se demonstrará nesta análise, estão relacionados e tangenciam-se em diversos aspectos. Além disso, destaca-se que serão retomados, com menor profundidade, diversos pontos já mencionados nos Capítulos supra, referentes ao processo decisório, na medida em que se visa à discussão de sua legitimidade.

\section{III.1. CONCEPÇÕes De ESTAdo DE DiReito E SUAS RELAÇÕES COM O PAPEL A SER DESEMPENHADO PELOS JUÍZES}

O papel a ser desempenhado pelos juízes, para que o Estado de Direito seja preservado, é um dos pontos centrais da temática da legitimidade política da decisão judicial sobre um caso controverso. Os juízes, ao decidirem os casos difíceis, devem fazer juízos políticos, que a princípio seriam da esfera de outro Poder? Essa pergunta é a chave deste ponto inicial.

Na concepção de Dworkin, tanto nos Estados Unidos, quanto na Grã-Bretanha, os Tribunais Constitucionais decidem questões que envolvem controvérsias políticas, e, nestes casos, para fundamentar suas decisões, devem 
buscar fundamentos nos princípios de moralidade política daquela comunidade - por exemplo, a liberdade, a igualdade etc. - que, para o autor, seriam distintos da agenda partidária de qualquer grupo político.

Dworkin esclarece que, na Grã-Bretanha, é forte a ideia de que os juízes não devem tomar decisões políticas, embora, na prática o façam. A esse respeito, um dos autores ingleses exponenciais, que escreveram sobre o tema e é comentado por Dworkin, é John Griffiths, com sua obra The Politics of the Judiciary $^{212}$, a qual analisa algumas decisões políticas da Câmara dos Lordes inglesa, que, embora enviesadas por fundamentos jurídicos, não passavam de decisões essencialmente políticas. ${ }^{213}$

Nos Estados Unidos, esse debate sobre o caráter político das decisões mostra-se um pouco mais dividido, de acordo com Dworkin, pois há juristas que defendem abertamente que as decisões judiciais podem e devem ser políticas. Esse caráter político, inclusive, nesta perspectiva, não estaria restrito apenas às questões constitucionais, mas também se aplicaria a decisões de tribunais inferiores relativas à legislação infra-constitucional. É uma visão progressista, que reveste o juiz desse forte papel político, atribuindo-lhe um poder de criação mais amplo, típico do poder legislativo.

Ronald Dworkin não concorda com nenhuma dessas duas visões apresentadas, i.e., a posição majoritária inglesa, de que nunca se deve fazer juízos políticos nas decisões judiciais, ainda que elas versem sobre casos controversos; e a visão progressista norte-americana, que defende a ampla

${ }^{212}$ GRIFFITHS, John, The Politics of the Judiciary. Nova Iorque: Fontana Books, 1977

213 "Griffiths acredita que em cada um desses casos (e em muitos outros que discute) a Câmara agiu a partir de uma postura política particular, que defende valores ou estruturas sociais estabelecidas e se opõe a reforma. Ele não diz que os juízes que tomam essas decisões tinham consciência de que, contrariamente à visão oficial de sua função, estavam impondo uma posição política. Mas crê que, não obstante, era isso que estavam fazendo." DWORKIN, Ronald. Uma questão de princípio, cit., p. 5 
liberdade dos juízos na seara política. Ele acredita que ambas as posições não consideram uma distinção pertinente a uma análise mais acurada da questão, qual seja, a diferença entre os argumentos de princípio político e os argumentos de procedimento político.

Os argumentos de princípio político seriam aqueles relativos a "direitos políticos de cidadãos individuais"; e os argumentos de procedimento político destinar-se-iam a fundamentar "que uma decisão particular promova alguma concepção de bem-estar geral ou interesse público "214. Os juízes ao se depararem com um caso controverso devem julgar com base em argumentos de princípio político, não de procedimento político, na concepção de Ronald Dworkin, pois os argumentos de princípio político são argumentos de Direito. ${ }^{215}$

A consideração desses argumentos de princípios políticos como argumentos de Direito depende da concepção do que seria o Estado de Direito. Dworkin esclarece que há duas formas centrais de concebê-lo: (i) uma concepção centrada no texto legal; e (ii) uma concepção centrada nos direitos.

De acordo com Dworkin, a concepção centrada no texto legal defende que:

“o poder de Estado nunca deve ser exercido contra os cidadãos individuais, a não ser em conformidade com regras

214 DWORKIN, Ronald. Uma questão de princípio, cit, p. 6

${ }^{215}$ Ronald Dworkin destaca que a distinção entre princípios políticos e procedimento político remete a uma diferença anterior entre política e princípios. Os princípios são proposições que descrevem direitos e a política são proposições que descrevem objetivos. Ressalta-se que a diferença entre os conceitos de política e princípios foi aprofundada em capítulo próprio, Capítulo II.1.3., neste momento, apenas se retomou algumas ideias necessárias ao desenvolvimento do presente Capítulo. Dworkin afirma que: “Os argumentos de princípio são argumentos destinados a estabelecer um direito individual; os argumentos de política são argumentos destinados a estabelecer um objetivo coletivo. Os princípios são proposições que descrevem direitos; as políticas são proposições que descrevem objetivos. Mas o que são os direitos e os objetivos, e qual a diferença?" DWORKIN, Ronald. Levando os direitos a sério, cit., p. 141 
explicitamente especificadas num conjunto de normas públicas à disposição de todos. (...) Enfatiza que, sejam quais forem as regras colocadas no "livro das regras", elas devem ser seguidas até serem modificadas. Os que tem essa concepção do Estado de Direito realmente se importam com o conteúdo das normas jurídicas, mas dizem que isso é uma questão de justiça substantiva e que a justiça substantiva é um ideal diverso que não é, em nenhum sentido, parte do ideal do Estado de Direito." 216

Desse modo, o juiz seria um mero reprodutor de normas, teria sua função de julgar, independentemente do caso ser fácil ou difícil, limitada à letra estrita da lei, para que o Estado de Direito, assim concebido, não fosse seriamente violado.

Essa forma de conceber o papel do juiz, neste Estado de Direito centrado nas regras, assemelha-se muito com a concepção mecânica proposta pela Escola da Exegese, que desconsidera o conteúdo, ou o fim do Direito, em favor da segurança jurídica. A respeito dessa teoria, o professor Celso Lafer esclarece que:

"Em nome da segurança, da certeza e da racionalidade do legislador que, com base na doutrina da separação de poderes, a Escola da Exegese afirmou o silogismo jurídico enquanto expressão de um juízo determinante (...). Para isso, o juiz deverá formular um silogismo, cuja premissa maior seria fornecida pela regra de Direito apropriada, a menor pela verificação de que as condições de fato, previstas na norma, ocorreram, decorrendo a sentença, logicamente, da conclusão do silogismo." 217

A desconsideração da finalidade do Direito com o centrismo nas regras mostra-se inadequada e insuficiente para atender as demandas sociais da sociedade complexa em que se vive. Por ela, correr-se-ia o risco de colocar em

${ }^{216}$ DWORKIN, Ronald. Uma questão de princípio, cit., p. 7

${ }^{217}$ LAFER, Celso. A reconstrução dos direitos humanos. Um diálogo com o pensamento de Hannah Arendt. São Paulo: Cia das Letras, 1988, pp. 280-81 
prática decisões nada razoáveis sob o ponto de vista da justiça, da equidade e dos princípios morais de uma comunidade política. Desse modo, como alternativa a esta teoria de Estado de Direito centrada nas regras, Dworkin desenvolveu a concepção centrada nos direitos, a qual defende que:

\begin{abstract}
“(...) os cidadãos têm direitos e deveres morais entre si e direitos políticos perante o Estado como um todo. Insiste em que esses direitos morais e políticos sejam reconhecidos no Direito positivo, para que possam ser impostos quando da exigência de cidadãos individuais por meio de tribunais e outras instituições judiciais do tipo conhecido, na medida que isso seja praticável. (...) Não distingue, como faz a concepção centrada no texto legal, entre o Estado de Direito e a justiça substantiva; pelo contrário, exige, como parte ideal do Direito, que o texto legal retrate os direitos morais e os aplique." 218
\end{abstract}

Esta concepção centrada nos direitos, proposta por Dworkin, alinha-se à ideia de legitimidade do Estado de Direito defendida por Eros Roberto Grau, segundo a qual a legitimidade do Direito não se confunde com a ideia de legalidade; ela é mais ampla que esta e, por vezes, podem até mesmo confrontarem-se $\mathrm{s}^{219}$. A legitimidade, para Eros Roberto Grau, funda-se nos padrões histórico-culturais, os quais se diferenciam da vontade da maioria eventual, portanto, essa concepção aproxima-se da ideia defendida por Dworkin, segundo a qual os direitos não se limitam ao que foi positivado (concepção centrada nas regras), conforme os processos majoritários, encontram respaldo na moralidade política da comunidade e, por isso, são mais amplos do que o que se assenta na lei.

${ }^{218}$ DWORKIN, Ronald. Uma questão de princípio, cit., p. 7

219 "A legitimidade que ora cuido, pois - legitimidade que não se identifica com a legalidade; legitimidade do direito posto -, é produto da autoridade, entendida esta como decorrente da captação de padrões histórico-culturais, e não da captação de qualquer vontade ou conjunto de vontades, razão pela qual dispenso, em minha concepção, o recurso à ideia de "consenso social". A construção histórica desses padrões passa à margem de um contrato social e da regra da maioria." GRAU, Eros Roberto. $O$ direito posto e o direito pressuposto. 8a. edição, São Paulo: Malheiros, 2011, p. 88 
$\mathrm{Na}$ concepção centrada nos direitos, que é uma forma mais elaborada de conceber o Estado de Direito, Dworkin aponta a possibilidade dela não ser bem sucedida em três aspectos, quais sejam: o Estado pode fracassar no âmbito da efetividade dos direitos individuais que alega impor; o Estado pode não ser preciso no reconhecimento de direitos individuais importantes; e, por fim, pode não ser equânime na imposição desses direitos, de modo que haja um tratamento diferenciado injustificado entre os cidadãos, em razão de classe, raça, condição social etc. Porém, ainda assim, ela seria melhor de que a concepção centrada nas regras, conforme será demonstrado.

Prosseguindo a análise dessas duas concepções, Dworkin aprofunda as suas diferenças, primeiro, no que se refere aos pressupostos para alcançar a justiça ${ }^{220}$; segundo, quanto à crítica à neutralidade filosófica dessas concepções; e terceiro, quanto à resolução dos casos controversos.

Com relação à primeira diferença, Dworkin esclarece que para que se alcance o ideal de justiça, na concepção centrada nas regras, exigir-se-ia um elevado grau de aquiescência às leis pelos cidadãos e a atuação do governo em conformidade a este repertório legal. Ele aponta que a aquiescência à lei, embora seja necessária, não é suficiente para que se alcance o ideal de justiça, pois o conteúdo das regras pode ser muito injusto ${ }^{221}$, por exemplo, com a criação de leis discriminatórias impostas pela maioria dos membros daquela comunidade a uma minoria política. A deficiência da aquiescência encontra-se nesta ideia de que ela, por si só, não controla o conteúdo das leis, há apenas uma expectativa de que a maioria seja sensata e não pratique barbaridades, mas isso é

${ }^{220}$ Dworkin afirma que essas concepções de Estado de Direito, embora muito diversas no que se refere à prestação jurisdicional, apresentam um objetivo comum que é uma sociedade mais justa, por meio de seus modelos adotados. Em outras palavras, cada uma tenta realizar, ao seu modo, esse objetivo caro a ambas.

221 "Mas a aquiescência às leis evidentemente não é suficiente para a justiça; a aquiescência plena provocará injustiça muito séria se suas regras forem injustas." DWORKIN, Ronald. Uma questão de princípio, cit., p. 8 
apenas uma expectativa, que não garante o ideal de justiça.

Ainda nesta seara, é importante destacar que a ideia de aquiescência à lei por parte dos cidadãos é muito vinculada à ideia de legitimidade política, porque os homens quando fazem as leis que os governam se auto-determinam, isto é, são livres no aspecto da liberdade positiva. ${ }^{222} \mathrm{~A}$ liberdade positiva como ensina o professor Celso Lafer é:

“(...) autonomia: direito de se reger pela própria lei. A liberdade, nesta acepção da autonomia, coincide com a esfera do obrigatório, porém o obrigatório resulta da obediência à própria lei coletivamente elaborada na praça pública. A liberdade antiga sugere o que Kant chamou de 'liberdade legal', ou seja, a faculdade de obedecer apenas à lei exterior à qual se pode dar assentimento. O seu oposto é a heteronomia da norma imposta por poucos em relação a todos."223

É evidente que a aquiescência à lei, enquanto expressão da liberdade positiva dos cidadãos, é importante no que tange à legitimidade e significa um valor político importante para o Estado de Direito, todavia, como já foi mencionado, não representa garantia de realização do ideal de justiça, significa apenas um passo desejável para a sua realização.

Feita essa análise do primeiro aspecto colocado em questão - os pressupostos para se alcançar esta meta comum de justiça -, na concepção centrada nas regras, passa-se a analisar a realização desse ideal de justiça na concepção centrada nos direitos. Para Dworkin, se não houver falhas nas

222 'O sentido 'positivo' da palavra 'liberdade' tem origem no desejo do indivíduo de ser seu próprio amo e senhor. Quero que minha vida e minhas decisões dependam de mim mesmo e não de forças externas de qualquer tipo. Quero ser instrumento de mim mesmo e não dos atos de vontade de outros homens (...). Sinto-me livre na medida que creio na verdade disso e sinto-me escravizado na medida em que me forçam a reconhecer que não existe tal verdade." BERLIN, Isaiah. Quatro ensaios sobre a liberdade. Brasília, Editora Universidade de Brasília, 1981, p. 142

223 LAFER, Celso. "O moderno e o antigo conceito de liberdade" in Ensaios sobre a liberdade. São Paulo: Perspectiva, 1980, cap. 1., p. 14 
dimensões desta concepção - reconhecimento de direitos individuais importantes; efetividade e equidade na imposição desses direitos reconhecidos chegar-se-á muito perto de uma sociedade justa, ainda que esta seja mal administrada, ou desprovida de outras qualidades desejáveis para uma comunidade política. ${ }^{224}$

Com relação ao segundo aspecto colocado em questão, qual seja, a crítica à neutralidade filosófica dessas concepções, Dworkin esclarece que a concepção centrada nos direitos sofre mais objeções que as concepções centradas nas regras, conforme abaixo explicado.

A concepção centrada nos direitos, como ela pressupõe que os cidadãos têm direitos morais, $i$. e., possuem direitos não positivados, recebe a crítica de que esses direitos morais são controvertidos, inclusive do ponto de vista filosófico, desse modo, esta concepção falharia na dimensão da exatidão dos direitos que reconhece. ${ }^{225}$ Todavia, deve-se destacar que essa inexatidão pode ocorrer até mesmo com direitos escritos, por exemplo, com os princípios positivados na Constituição, que por serem genéricos não estipulam uma

${ }^{224}$ Dworkin esclarece que há críticos que defendem ser desnecessária a concepção centrada nos direitos para que alcance uma sociedade justa: "a concepção centrada nos direitos não é necessária para uma sociedade justa porque, para que os direitos dos cidadãos sejam protegidos, não é necessário que os cidadãos sejam capazes de exigir o julgamento e a imposição desses direitos como indivíduos. Um governo de funcionários sábios e justos protegerá os direitos (assim diz o argumento) por sua própria iniciativa, sem o processo pelo qual os cidadãos podem discutir, como indivíduos, o que são esses direitos. Na verdade, a concepção do Estado de Direito centrada nos direitos, que insiste na importância dessa oportunidade, é muitas vezes rejeitada como legalista, como encorajadora de uma preocupação egoísta com a propriedade e os direitos individuais.” DWORKIN, Ronald. Uma questão de princípio, cit, p. 9

225 "Muitos filósofos, porém, duvidam que as pessoas tenham quaisquer direitos que não os concedidos a elas por leis ou outras decisões oficiais, ou mesmo que a ideia de tais direitos faça sentido. Duvidam particularmente que seja sensato dizer que as pessoas têm direitos morais quando (como a concepção centrada nos direitos deve admitir que ocorre frequentemente) é controvertido numa comunidade quais direitos morais ela têm. Isto é, a concepção pode falhar na dimensão da exatidão mesmo quando é controvertido se falhou ou não; mas isso é apenas o que os filósofos duvidam que faça sentido. A concepção centrada nos direitos, portanto, parece aberta à objeção de que ela pressupõe um ponto de vista filosófico que é, ele próprio, controvertido, e que, portanto, não será aceito por todos os membros da comunidade." DWORKIN, Ronald. Uma questão de princípio, cit., p. 9 
solução exata e prévia ao problema colocado em questão. ${ }^{226}$ Desse modo, como nem os direitos positivados, após a expansão axiológica do Direito ${ }^{227}$ com a positivação de princípios, estão livres e isentos das controvérsias, o argumento desses críticos não se justificaria.

Por fim, o terceiro ponto, que merece análise quanto às distinções dessas concepções de Estado de Direito, é a forma que cada uma indica para se decidir um caso controverso. Esta questão é muito relevante à análise que se realizou ao longo deste trabalho.

Com relação a essa distinção do método para decidir um caso controverso, conforme a concepção de Estado de Direito adotada, a pergunta, que foi feita no início deste Capítulo e que aqui se retoma, é se os juízes devem tomar decisões políticas nos casos controvertidos? A resposta que a concepção centrada nas regras dará a essa pergunta é a de que o juiz não deve decidir de maneira política os casos controversos, ao contrário, deve buscar o que realmente o texto jurídico indica, ainda que, em um primeiro momento, isso não pareça claro a ele. De acordo com Dworkin, a razão de rejeitarem a ideia do juiz poder decidir, politicamente, é o fato deste juízo político não estar no texto legal, mas apenas ser expressão do que o juiz acredita que deveria estar nele.

226 “É o caso da Constituição de 1988. Princípios são genéricos em contraste com as regras, que são específicas. E é precisamente na interpretação e exegese da aplicação dos princípios constitucionais, que não têm a especificidade das regras, que os grandes temas da Filosofia do Direito se colocam e vêm sendo elaborados em função dos problemas colocados para os juristas à luz da experiência jurídica." LAFER, Celso. Filosofia do direito e princípios gerais: considerações sobre a pergunta 'O que é a Filosofia do Direito?'. In: Alaôr Caffé Alves e outros. (Org.). O que é a Filosofia do Direito?, Barueri: Manole, 2004, p. 57

227 “A expansão axiológica do Direito é um dos objetivos dos princípios gerais que permeiam as Constituições contemporâneas, inclusive a Constituição do Brasil de 1988, que assinala, no plano jurídico, a passagem política do regime autoritário-militar para a democracia. Por esta razão, a Constituição brasileira de 1988, como Constituição programática, não se limitou a distribuir competências e garantir direitos. Caracteriza-se pela substantiva incorporação de princípios gerais, voltados para indicar um sentido de direção que a Constituição busca imprimir à sociedade brasileira." LAFER, Celso. A Constituição de 1988 e as relações internacionais- reflexões sobre o art. $4^{o}$. In: A internacionalização dos direitos humanos: Constituição, racismo e relações internacionais. Barueri: Manole, 2005. p. 13 
Nesse sentido, o juiz se agisse desse modo estaria desrespeitando a separação dos Poderes, agindo como se legislador fosse.

Uma crítica que Dworkin faz com relação ao método apresentado para resolver os casos difíceis, por esta concepção centrada no livro de regras, é com relação a essa suposta possibilidade de se buscar o que realmente está no texto legal. Os casos controversos revelam exatamente a incerteza de se saber qual regra é determinante para a resolução do caso, porque como Dworkin afirma "as regras que ali estão falam com voz incerta",228.

Com o propósito de se saber o que a regra realmente quer dizer foram desenvolvidos inúmeros métodos de interpretação centrados no texto legal. Essas técnicas são múltiplas e, no momento, serão selecionadas apenas algumas delas apontadas por Dworkin como relevantes ao debate por ele proposto.

A primeira técnica apresentada é a semântica, que se volta para o significado do texto positivado pelo legislador. Quando uma expressão, ou palavra usada pelo legislador, gera controvérsia, os intérpretes buscam o seu significado, até então dúbio, de diversas maneiras, podem recorrer ao significado comum daquela palavra, o significado que ela tem em outros textos legais, a forma como ela se conecta com outra palavra etc. O que é importante ressaltar, a esse respeito, é que o significado buscado pelo juiz não será unânime, muitos irão discordar de sua interpretação ${ }^{229}$, embora ele possa ter sido

${ }^{228}$ DWORKIN, Ronald, Uma questão de princípio, cit, p.10

${ }^{229}$ A respeito dessa técnica o Professor Tércio Sampaio Ferraz Junior esclarece que: "Quando se enfrenta uma questão léxica, a doutrina costuma falar em interpretação gramatical. Parte-se do pressuposto de que a ordem das palavras e o modo como elas estão conectadas são importantes para obter-se o correto significado da norma. Assim, dúvidas podem surgir, quando a norma conecta substantivos e adjetivos ou usa pronomes relativos. Ao valer-se da língua natural, o legislador está sujeito a equivocidades que, por não existirem nessas línguas de rigor (como na ciência), produzem perplexidades." FERRAZ JUNIOR, Tércio Sampaio. Introdução ao Estudo do Direito. Técnica, 
cuidadoso e agido de boa-fé na busca deste significado. O que não se pode negar, na empreitada realizada por esses juízes, é que eles tentam ser fiéis ao propósito exigido pela concepção centrada nas regras do Estado de Direito, isto é, descobrir o que realmente o texto legal queria dizer.

De acordo com Dworkin, esta técnica é muito utilizada na GrãBretanha pelos convencionalistas. Por outro lado, nos Estados Unidos, é mais popular a ideia de psicologia de grupo $^{230}$, que trabalha com uma ideia diversa da semântica, não focam no conteúdo das palavras, mas no processo decisório do legislador. $\mathrm{O}$ objetivo é saber o que os legisladores pretendiam quando positivaram uma determinada regra. Todavia, essa ideia de recorrer ao que o legislador pretendia que sua linguagem fizesse, também, não traz consenso entre os juristas, já que muitos vão dizer que o legislador pretendia um determinado resultado com a lei e outros que ele pretendia outro ${ }^{231}$. Isso porque quando os legisladores aprovam uma lei, se analisados os debates, pode-se observar as mais diversas pretensões sobre o que eles queriam que a lei aprovada fizesse.

Outra teoria sobre como identificar o que realmente o texto legal significa, tal como exigido pela concepção centrada nas regras, apresentada por Dworkin, é a histórica contrafactual. Esta teoria defende que, na resolução dos

\footnotetext{
Decisão e Dominação, $4^{\mathrm{a}}$ ed., São Paulo: Atlas, 2003, p. 283

${ }^{230}$ Essa ideia se aproxima muito da teoria originalista, apresentada por Dworkin, em seu livro " $O$ direito da liberdade: A leitura moral da Constituição norte-americana", a qual defende que, no processo de aplicação da lei, deve-se tentar desvendar o desejo do legislador quanto às consequências do dispositivo legal que aprovou. No originalismo, a Constituição significa aquilo que o legislador queria que sua linguagem fizesse. Assim, limitam-se as possibilidades de interpretação dos juízes, os quais ficam presos pelas expectativas dos autores daquele dispositivo. Dworkin discorda, veementemente, desta teoria.

231 "Mais uma vez, não ocorre aqui nenhuma suposição de que todos os juristas sensatos concordarão quanto ao que os legisladores pretendiam. Pelo contrário, os defensores do modelo centrado no repertório legislativo sabem que mesmo advogados habilidosos discordarão no que diz respeito a inferências da intenção legislativa extraídas de uma mesma prova. Insiste, não obstante, em que a questão da intenção é a pergunta certa a se fazer, pois cada juiz que a faz está, pelo menos, fazendo o melhor que pode para seguir o modelo do repertório legal e, portanto (segundo sua concepção), seguir o Estado de Direito.” DWORKIN, Ronald. Uma questão de princípio, cit., p.12
} 
casos difíceis, não se deve nem recorrer à semântica, nem à intenção do legislador quanto ao que queriam que determinado dispositivo legal fizesse, mas ao que os legisladores teriam decidido, caso se deparassem com o caso concreto controverso, ou seja, qual solução eles teriam dado àquela questão difícil colocada em relevo. Dworkin afirma que, igualmente às demais teorias, não se teria consenso sobre a decisão mais acertada, já que esta seria produto de um exercício especulativo que trabalha com hipóteses não demonstráveis sobre um provável juízo do legislador.

Feitas essas considerações, pode-se afirmar que a análise dessas três teorias demonstram a tentativa de se respeitar o texto legal, reverenciar a vontade do legislador ao positivar um determinado dispositivo, e refutar a possibilidade de um juízo político feito pelos juízes, já que, na concepção centrada nas regras, busca-se a neutralidade do julgamento e o respeito à separação dos Poderes, por meio da obediência ao texto legal e à vontade do legislador.

Em oposição, como já foi mencionado, na concepção centrada nos direitos, permite-se a interface entre Política e Direito, uma vez que os direitos podem ser morais e indicar princípios políticos que devem ser observados, independentemente, do texto legal positivado. Esta concepção não desconsidera o texto legal, mas não condiciona a existência do Direito a ele, tal como esclarece Dworkin:

“(...) a questão final que ela apresenta em um caso controverso é a questão de determinar se um queixoso tem o direito moral de receber de um tribunal aquilo que exige. O texto jurídico é relevante para essa questão final. Numa democracia, as pessoas têm, pelo menos, um forte direito moral prima facie a de que os tribunais imponham os direitos que o legislativo aprovou. É por isso que alguns casos são casos fáceis no modelo centrado nos direitos, assim como no modelo centrado no texto jurídico. Se 
está claro o que o legislativo lhes concedeu, então também está claro o que elas têm direito moral de receber no tribunal. (Esse enunciado deve ser ressalvado numa democracia cuja Constituição limita o poder legislativo. Deve também ser ressalvado - embora seja uma questão complexa quais devem ser as ressalvas - numa democracia cujas leis são fundamentalmente injustas)."232

A prestação jurisdicional desta concepção centrada nos direitos indica que, ainda que não haja uma lei positivada, o cidadão tem direito de ter seu pleito reconhecido perante um Tribunal, caso demonstre ter um direito moral que o subsidie. Esses direitos morais, em geral, são positivados na forma de princípios pela comunidade política, e, ainda que não sejam, devem passar pelo crivo de uma análise que considere a legislação positivada. Dworkin esclarece o que seria essa consideração à legislação positivada: o juiz deveria levar em conta o conjunto de normas jurídicas positivadas de uma comunidade política e analisar se a aplicação daquele princípio é adequada, ou não, a este conjunto. Em outras palavras, o juiz não deve impor todo e qualquer princípio, que considere compatível com suas convicções pessoais, como fundamento para a resolução de um caso controverso, mas apenas aqueles que passam por essa dimensão de adequação, necessária a visão de Direito como integridade de Dworkin. ${ }^{233}$ Todavia, esta limitação não implica na ausência de um julgamento, em certa medida, político realizado pelo juiz, porquanto este escolhe, dentre uma gama de princípios compatíveis, aqueles que consideram mais adequados à resolução do caso controverso ${ }^{234}$. A decisão pode ser considerada política apenas

${ }^{232}$ DWORKIN, Ronald. Uma questão de princípio, cit, p.14

233 A visão de Dworkin do Direito como integridade foi aprofundada no Capítulo II.1, relativo ao conceito de Direito por ele desenvolvido.

234 "A questão diante de uma corte é como um caso difícil deve ser decidido. Uma corte pode responsavelmente decidir um caso apelando somente a padrões que são capazes de determinar o que deveria ser feito. Se a orientação da lei foi esgotada, isso parece implicar que as cortes deveriam decidir tais casos apelando para princípios morais. Se isso é assumido, então podemos dizer que os juízes são impelidos pelo dever de decidirem casos difíceis utilizando-se de princípios morais, porque esta é única forma possível de proceder. Qualquer fracasso em decidir um caso difícil seria uma quebra do dever judicial, uma questão de erro judicial. Isso sugere outra possível "conexão necessária" entre a lei e aqueles princípios morais que o dever judicial requer que sejam usados ao 
neste aspecto de escolha a se fazer, tendo em vista que o juiz não deve, pela teoria da decisão judicial de Dworkin, fundamentar sua decisão em argumentos de política, mas de princípios $^{235}$, como já foi ressaltado no Capítulo II.1.3. (Diferenças entre regras, princípios e políticas). ${ }^{236}$

A esse respeito, destaca-se que esta concepção de ser possível uma decisão política, na medida em que esta consistiria em uma escolha a se fazer pelo intérprete, alinha-se a tese defendida por Eros Roberto Grau, segundo a qual, embora a interpretação do Direito seja orientada pelos princípios, os quais dão a necessária coerência a ele, não há uma neutralidade absoluta por parte do intérprete, na medida em que este faz escolhas. ${ }^{237}$ A concepção de Dworkin alinha-se a deste autor no que se refere aos casos difíceis, todavia, dela se distingue nos casos fáceis, em que há uma regra clara aplicável, pois Dworkin defende que, nestes casos, não há espaço para decisões políticas.

A necessidade de distinguir essas duas formas centrais de se conceber o Estado de Direito mostra-se relevante na medida em que implica em duas maneiras, também, diversas de se resolver os casos difíceis, uma que admite a possibilidade de se fazer juízos, em certa medida, políticos (concepção centrada nos direitos), que impliquem na definição, dentre as diversas

decidir casos difíceis." LYONS, David. As regras morais e a ética, Campinas: Papirus, 1990, p. 93

235 HABERMAS esclarece que na teoria de Dworkin: “(...) somente os argumentos de princípio, orientados pelo sistema de direitos, são capazes de conservar o nexo interno que liga a decisão no caso particular com a substância normativa da ordem jurídica em seu todo." HABERMAS, Jürgen. Direito e democracia: entre facticidade e validade, cit., p. 258

236 “Cada juiz que decide essa questão de princípio faz o que faz, não porque todas as possibilidades sejam excluídas pelo que já está na legislação, mas porque acredita que o seu princípio está correto ou, pelo menos, mais próximo de ser correto do que outros princípios também não excluídos. Assim, sua decisão é uma decisão política no sentido descrito. É justamente esse tipo de decisão política que a concepção centrada na legislação regularmente condena." DWORKIN, Ronald. Uma questão de princípio, cit., p. 16

237 "A interpretação do direito deve ser dominada pela força dos princípios; são eles que conferem coerência ao sistema. (...) De todo modo, ainda que os princípios vinculem, a neutralidade política do intérprete só existe nos livros. Na práxis do direito ela se dissolve, sempre. Lembre-se que todas as decisões jurídicas, porque jurídicas, são políticas." GRAU, Eros Roberto. Ensaio e discurso sobre a interpretação/aplicação do direito, 4a edição, São Paulo: Malheiros, 2006, p. 55 
possibilidades de soluções adequadas, de uma única decisão judicial, aquela que melhor justifique a prática jurídica sem limitar-se ao que foi positivado; e a outra que limita a decisão estritamente ao direito positivado (concepção centrada nas regras).

Esta análise é crucial na afirmação da legitimidade das decisões nos casos difíceis, seja por uma concepção, ou pela outra. Os defensores da concepção centrada nas regras não considerarão legítimas as decisões que recorram a fundamentos distintos do texto legal. Assim como a concepção centrada nos direitos não considerará legítima uma decisão fundada no texto da lei, que viole direitos morais do cidadão. A legitimidade das decisões judiciais, nesse sentido, irá variar de acordo com a própria concepção que cada um tem sobre o que é o Estado de Direito.

\section{III.2. O PROBLEMA DA COERÇÃO NOS CASOS CONTROVERSOS}

A questão que se vislumbra neste capítulo é se é legítimo o uso da coerção estatal em um caso controverso, no qual as partes não têm prima facie um direito que lhes permita o ganho de causa, ou o dever que lhes imponha alguma sucumbência.

A esse respeito, é importante retomar que, nos casos fáceis, não há grande discussão, porque eles resolvem-se com as $\operatorname{regras}^{238}$, as quais

238 Destaca-se que a resposta ao caso, a decisão judicial, é fácil, porque funda-se claramente na regra, há uma subsunção perfeita entre o caso e a norma a ele aplicável, não suscitando grandes dúvidas ao julgador. Nestes casos, a dimensão de moralidade é decorrente do fundamento da autoridade do juiz, que se firma com base em princípios da comunidade política como a Democracia, o Estado de Direito etc., nesse sentido, MichaEL S. MOORE: "Judges make people do things they do not want to do. With all the force of the state behind them, they coerce people into giving up their money, their liberty, their children, and their lives. Such coercion requires justification. The immediate justification for each occasion of judicial coercion is of course the (obvious) law itself: a judge might justify his judgment in a particular criminal case, for example, by a penal statute which directs him to 
especificam resultados determinados para as condutas, enquanto os casos difíceis resolvem-se pelos princípios, que não determinam um resultado específico, mas apenas indicam uma direção para se decidir o caso. ${ }^{239}$ Carla Faralli, ao esclarecer o pensamento de Dworkin a respeito dessa distinção entre regras e princípios, afirma que:

\begin{abstract}
"Os principles são realidades heterogêneas em relação às regras, mas são complementares a elas no ordenamento jurídico: as regras são válidas enquanto normas estabelecidas, e podem ser mudadas somente por força de uma deliberação, enquanto os princípios são válidos enquanto correspondem a exigências morais sentidas num período específico, e seu peso relativo pode mudar no decorrer do tempo. Os tribunais devem recorrer a estes últimos para resolver os casos difíceis (hard cases), aos quais não seria possível aplicar uma regra sem cometer uma injustiça." 240
\end{abstract}

A resolução dos casos controversos pela teoria proposta por

Dworkin exige essa consideração aos princípios e, por conseguinte, abala a expectativa de segurança jurídica do cidadão, na medida em que não se sabe qual das partes se sagrará vencedora, pois o direito de nenhuma delas é evidente prima facie. A partir disso, questiona-se o seguinte: posso ser coagido a cumprir uma determinada obrigação, se não tinha o conhecimento prévio dela, não

so decide. But the thoughtful judge regresses the question of justification: what justifies the judge in regarding that criminal statute as imposing this obligation upon her? The answer is presumably in terms of some doctrines of legislative supremacy and the ban on common law crimes. But what makes those doctrines a source of judicial obligation? Presumably, some political ideals such as democracy, the separation of powers, and the rule of law. By this time the thoughtful judge is deep into the morality of such ideals even in applying the most obvious cases." MOORE, Michael S. Four Reflections on Law and Morality. William and Mary Law Review, vol. 48, 2007, p. 1528

239 “(...) somente regras ditam resultados. Quando se obtém um resultado contrário, a regra é abandonada ou mudada. Os princípios não funcionam dessa maneira; eles inclinam a decisão em uma direção, embora de maneira não conclusiva. E sobrevivem intactos quando não prevalecem. Esta não parece uma razão para concluir que juízes devem haver-se com princípios possuam poder discricionário, já que um conjunto de princípios pode ditar um resultado. Se um juiz acredita que os princípios que ele tem obrigação de reconhecer apontam em uma direção e os princípios que apontam em outra direção não têm igual peso, então ele deve decidir de acordo com isso, do mesmo modo que ele deve seguir uma regra que ele acredita obrigatória. Ele pode, sem dúvida, estar errado na sua avaliação de princípios, mas pode também estar errado em seu juízo de que a regra é obrigatória." DWORKIN, Ronald. Levando os direitos a sério, cit., p. 57

240 FARALLI, Carla. A filosofia contemporânea do direito. Temas e desafios, Trad. Candice Premaor Gullo, São Paulo: Martins Fontes, 2006, pp. 4-5 
porque não conhecia a lei, mas porque a questão era efetivamente controversa?

Essa pergunta relaciona-se com a ideia do Direito como justificativa para a coerção oficial, isto é, o Estado somente pode coagir legitimamente alguém, se tiver fundamento no Direito daquela comunidade. Essa é uma construção que visa proteger o próprio cidadão contra a eventual arbitrariedade de seus governantes. Remete a ideia de governo das leis e não dos homens, nesse sentido, o professor Tércio Sampaio Ferraz Junior esclarece que:

"Para um homem comum, o direito por vezes aparece como um conjunto de símbolos incoerentes, que o torna inseguro, por exemplo, quando se vê envolvido numa pendência processual. Confrontado com os direitos do outro, estes, embora the pareçam ilegítimos, também são afirmados. É claro que seria impensável que o direito admitisse oficialmente que se move em múltiplas e incoerentes direções. Seu êxito, como força unificadora, depende, pois, de se dar um significado efetivo à idéia de um governo do direito, unificado e racional. Para isso trabalha a hermenêtica. Funcionalmente (cf. Thurman, 1971:51), a finalidade da teoria dogmática (da interpretação) consiste em ser uma caixa de ressonância das esperanças prevalecentes e das preocupações dominantes dos que crêem no governo do direito acima do arbítrio dos homens. ${ }^{241}$

A partir dessa análise, pode-se afirmar que os direitos nãopositivados, quando utilizados para fundamentar uma decisão sobre um caso controverso, seriam produto do governo dos homens e não das leis? Dworkin responderia não a essa pergunta, porque o juiz não pode impor toda e qualquer convicção pessoal para atribuir direitos às partes, não é uma escolha arbitrária, há um dever de observar a dimensão da adequação do Direito e, além disso, deve haver uma justificação para a sua escolha ${ }^{242}$.

${ }^{241}$ FERRAZ JUNIOR, Tércio Sampaio, Introdução ao Estudo do Direito..., cit., p. 285

${ }^{242}$ Esta análise foi aprofundada no Capítulo II.1. (O Conceito de Direito para Ronald Dworkin), por ora, apenas remete-se ao que significa a adequação e a justificação, dentro da perspectiva do direito como um romance em cadeia. A adequação determina que o juiz "não pode adotar nenhuma interpretação, por mais complexa que seja, se acredita que nenhum autor que se põe a escrever um 
Nesta seara, outra pergunta que se poderia fazer é se os direitos não-positivados não seriam propriamente direitos e, em razão disso, o Estado não estaria legitimamente autorizado a exercer seu poder de coerção para fazêlos cumprir. Volta-se à concepção do Estado de Direito. Se responder sim a essa pergunta, isto é, que os direitos não-positivados não são direitos, não posso coagir, ou obrigar a parte a cumprir uma decisão judicial proferida em um caso controverso, porque eles não fariam parte do Direito (concepção centrada nas regras). Por outro lado, na concepção de Estado de Direito centrada nos direitos, os direitos não-positivados, desde que tenham respaldo na moralidade política de uma comunidade, são direitos tanto quanto os contidos no texto positivado, o que legitimaria o uso da coerção estatal para fazer cumprir as decisões judiciais que neles se fundamentem. ${ }^{243}$

Como se pôde observar, o poder legítimo de coagir do Estado está condicionado àquilo que se entende por Direito, o que afeta diretamente a maneira como se concebe a legitimidade de um Estado e, nesse sentido, Dworkin afirma que:

“Um Estado é legítimo se sua estrutura e suas práticas constitucionais forem tais que seus cidadãos tenham uma obrigação geral de obedecer às decisões políticas que

romance com as diferentes leituras de personagem, trama, tema e objetivo que essa interpretação descreve, poderia ter escrito, de maneira substancial, o texto que lhe foi entregue”. A justificação: "vai exigir-lhe então que julgue qual dessas leituras possíveis se ajusta melhor à obra em desenvolvimento, depois de considerados todos os aspectos da questão”. DWORKIN, Ronald. $O$ império do Direito, cit., pp. 277-78.

243 A respeito dessa questão, EUSEBIO FERNÁNDEZ GARCíA tenta conectar a moral com a lei, esclarece que a obrigação de obedecer à lei é uma obrigação moral, portanto, as obrigações morais, as quais todos estão sujeitos e devem observar, são mais amplas que o direito positivado, e em alguma medida o fundamentam como elemento inicial do sistema legal: "En primer lugar, porque nuestra obligación fundamental de obedecer a la ley es una obligación moral y no una obligación legal. No puede ser una obligación legal porque esto nos llevaría de regreso al infinito: puesto que las obligaciones legales se derivan de leyes, tendría que haber una ley que dijese que debemos obedecer a la ley. (...) Se hay alguna obligación de obedecer la ley deve ser em última instancia una obligación moral." GARCÍA, Eusebio Fernández. La obediencia al derecho, Madrid: Editorial Civitas S.A., 1987, p. 60 
pretendem impor-lhes deveres. Um argumento a favor da legitimidade só precisa oferecer razões para essa situação geral. Não precisa demonstrar que um governo, legítimo nesse sentido, tem autoridade moral para fazer o que bem entende com seus cidadãos, ou que estes sejam obrigados a obedecer a toda e qualquer decisão que venha a ser tomada. (...) Oferecenos, em particular, um forte argumento em favor de uma concepção do direito que considere a integridade fundamental, porque qualquer concepção deve explicar por que motivo o direito é a autoridade capaz de legitimar a coerção."244

A ideia da legitimidade do uso da força do Estado, nos casos controversos, em que há uma incerteza do direito das partes, como se tentou demonstrar, depende da maneira que se entende o Direito de uma comunidade política, isto é, qual seria o seu repertório, apenas o direito positivado, ou também nele se incluiria os direitos morais. Isso implica nos limites de atuação dos juízes, que aplicam esse direito na resolução dos casos concretos. Os juízes ao resolverem um caso difícil, pela teoria proposta por Ronald Dworkin, não advinham quais são esses direitos morais, a sua apreensão advém da visão do Direito como integridade ${ }^{245}$, que "oferece a melhor interpretação construtiva da prática jurídica de uma comunidade "246, e esta melhor interpretação tem limites (dimensões de adequação e justificação, mencionadas supra). Nesse passo, em síntese, a crítica central de que o uso da força estatal é ilegítimo, porque os cidadãos não sabem a que direitos e deveres estão submetidos, não se sustenta, porque não se trata de um procedimento arbitrário, fundado na convicção

${ }^{244}$ DWORKIN, Ronald. O império do Direito, cit., p. 232

245 ANDREI MARMOR comenta sobre o Direito como integridade de Dworkin e o importante papel desempenhado pela coerência neste conceito: "In his interpretative theory of law, Dworkin clearly distinguished between the role played by coherence at the methodological level, namely, in the form of a coherence theory of knowledge, and at the level of soundness, namely, as a particular value of political morality. In other words, Dworkin's concept of interpretation presupposes a coherence theory of knowledge which, however, once it is applied to law, must leave a room for coherence as a distinct value, as entailed by his concept of 'integrity'. As such a value, coherence is rendered a guiding principle for one particular interpretative strategy which may be chosen from among various others. Law as integrity urges judges to grasp their adjudicative assignment as guided primarily by concern with the moral value of coherence." MARMOR, Andrei. Interpretation and legal theory, cit., p. 53

${ }^{246}$ DWORKIN, Ronald. O império do direito, cit., p. 272 
pessoal do juiz, ao contrário, trata-se de um procedimento fundamentado na moralidade política de uma comunidade, que se constrói e solidifica-se ao longo de toda a sua existência, e pode ser conhecida por todos os cidadãos que a compõem.

\section{III.3. VIOLAÇÃO DA DEMOCRACIA}

O terceiro ponto em discussão, na temática da legitimidade, é a questão da eventual violação da Democracia pelo Poder Judiciário quando este resolve casos controversos recorrendo aos princípios, que não indicam uma decisão prima facie aos casos como as regras fazem. A esse respeito, questionase se os juízes estariam adentrando na seara exclusiva de outros Poderes, democraticamente, eleitos.

Essa questão é bastante repercutida na atualidade. Se a resposta for sim a essa pergunta, isto é, que os juízes estão adentrando na seara exclusiva de outros Poderes, está-se diante de um caso de ativismo judicial, que, de acordo com a doutrina dogmática, seria "o exercício da função jurisdicional para além dos limites impostos pelo próprio ordenamento que incumbe, institucionalmente, ao Poder Judiciário fazer atuar, resolvendo litígios de feições subjetivas (conflitos de interesse) e controvérsias jurídicas de natureza objetiva (conflito normativo) "247 como ensina o professor Elival da Silva Ramos. Dworkin, todavia, não considera sua teoria do direito como um suporte para o ativismo judicial:

"O ativismo é uma forma virulenta de pragmatismo jurídico. Um juiz ignora o texto da Constituição, a história de sua promulgação, as decisões anteriores da Suprema Corte que buscaram interpretá-la e as duradouras tradições de nossa cultura política. $\mathbf{O}$ ativista ignoraria tudo isso para impor a

${ }^{247}$ RAMOS, Elival da Silva. Ativismo Judicial. São Paulo: Saraiva, 2010, p. 129 
outros poderes do Estado seu próprio ponto de vista sobre o que a justiça exige. $O$ direito como integridade condena o ativismo e qualquer prática de jurisdição constitucional que lhe esteja próxima. Insiste que em que os juízes apliquem a Constituição por meio de interpretação, e não por fiat, querendo com isso dizer que suas decisões devem ajustar-se à prática constitucional, e não ignorá-la." ${ }^{248}$ (g.n.)

A teoria de Dworkin do Direito como integridade indica limites para que não haja a usurpação, pelos juízes, do poder pertencente a outras instituições políticas, democraticamente, eleitas. Para que se compreenda a crítica, amplamente ventilada, de violação da Democracia da teoria proposta por Dworkin, deve-se aprofundar a análise de alguns elementos importantes.

O primeiro deles é a ideia corrente de que o respeito à vontade da maioria, manifestada pelo legislador por meio de leis em uma Democracia representativa, significa o respeito à Democracia. Se a Democracia for de fato a vontade da maioria (premissa majoritária), os magistrados ao fazerem juízos morais dos princípios constitucionais, para que uma minoria não seja oprimida, estariam agindo de maneira antidemocrática. ${ }^{249}$

O segundo elemento relevante é a concepção de Dworkin acerca do que seria a Democracia, a esse propósito, ele desenvolve uma concepção própria, a concepção constitucional de Democracia, a qual defende que o objetivo da Democracia é tratar todos os cidadãos com igual consideração. ${ }^{250}$

\footnotetext{
${ }^{248}$ DWORKIN, Ronald. O império do direito, cit., p. 452

249 "Para eles, o entusiasmo pela leitura moral dentro de uma estrutura política que atribui aos juízes a suprema autoridade em matéria de interpretação é elitista, antipopulista, anti-republicana e antidemocrática. Como veremos, essa ideia se baseia num pressuposto bastante difundido, mas pouco estudado, acerca do vínculo entre a democracia e a vontade da maioria, pressuposto esse que, aliás, a história dos Estados Unidos sempre rejeitou. Quando compreendemos melhor a democracia, vemos que a leitura moral de uma constituição política não só não é antidemocrática como também, pelo contrário, é praticamente indispensável para a democracia". DWORKIN, Ronald. $O$ direito da liberdade: A leitura moral da Constituição norte-americana, cit., p. 9

${ }^{250}$ DWORKIN, Ronald. O direito da liberdade: A leitura moral da Constituição norte-americana, cit., p. 26
} 
Essa concepção alinha-se a defendida por Norberto Bobbio:

“(...) queremos não apenas compreender o que é a democracia, mas dar-lhe uma justificação, se queremos passar, como diria o filósofo, do juízo de fato ao juízo de valor, devemos, depois de ter discorrido sobre os meios, discorrer, mesmo que brevemente, também sobre o fim. $\mathrm{O}$ fim que nos move quando queremos um regime organizado democraticamente é, numa única palavra, a igualdade. Assim podemos definir a democracia, não mais com relação aos meios, mas relativamente ao fim, como o regime que visa realizar, tanto quanto possível, a igualdade entre os homens.,"251

Para que seja efetiva esta igualdade entre os cidadãos, os princípios morais positivados na Constituição devem ser interpretados da maneira mais geral possível, partindo da própria linguagem empregada pelo legislador, não de sua intenção quanto ao que desejaria que ocorresse a partir daquele dispositivo, como defendem os originalistas.

Como já foi mencionado, os princípios enviesados em dispositivos constitucionais abstratos não permitem qualquer juízo moral particular, ainda que sejam múltiplas as possibilidades de interpretação, há limites aos juízos morais feitos pelos juízes. ${ }^{252}$

Os juristas tentam encontrar meios de limitar o poder dos juízes, para que não haja a violação à Democracia e à separação dos Poderes. Dworkin a esse respeito menciona os originalistas ${ }^{253}$, que buscam limitar o poder dos

${ }^{251}$ BOBBIO, Norberto. Qual democracia?, São Paulo: Edições Loyola, 2009, p. 38

252 "Saliento as restrições da história e da integridade porque elas mostram o quanto é exagerada a queixa comum de que a leitura moral dá aos juízes um poder absoluto para impor a todos nós suas próprias conviç̧ões morais". DWORKIN, Ronald. O direito da liberdade: A leitura moral da Constituição norte-americana, cit., p. 17

253 Um dos maiores defensores do "originalismo" é ANTONIN SCALIA (Originalism: the lesser evil, The University of Cincinnati Law Review, vol. 57, 1989), o qual defende que é necessário recorrer à intenção histórica do legislador, ao positivar certo dispositivo legal, na medida em que a linguagem por si só não é suficiente para interpretar o significado daquela proposição jurídica positivada, de 
juízes à vontade dos legisladores, no que tange às consequências concretas, que gostariam que ocorressem, a partir do dispositivo legal que positivaram; por essa perspectiva, a Constituição e as leis significariam aquilo que o legislador queria que sua linguagem fizesse. É, plenamente, possível fazer aqui um paralelo do originalismo com as correntes explanadas no Capítulo III.1. (semântica, psicologia de grupo e histórica contrafactual) adequadas à concepção de Estado de Direito centrado nas regras.

A doutrina dworkiana rejeita o originalismo, pois entende que esta forma de conceber as leis impede que haja qualquer tipo de atualização, ou adaptação aos novos tempos da legislação, e como elemento empírico de falha dessa doutrina, demonstra com casos concretos a sua inadequação. A esse propósito, Dworkin menciona o caso Brown vs. Board of Education, no qual a Suprema Corte norte-americana decidiu pela cessação da segregação racial nas escolas públicas, com base na Décima Quarta Emenda da Constituição norteamericana, consagradora da igualdade entre os cidadãos. Se os juízes que compunham a Suprema Corte, à época, tivessem adotado a estratégia originalista para resolver este caso, teriam mantido a segregação, uma vez que os próprios legisladores não pretendiam, quando elaboraram tal dispositivo

modo que, considerar apenas a linguagem, poderia conduzir o intérprete a fazer do dispositivo legal aquilo que ele gostaria que ele fosse, e não aquilo que ele realmente é: "Originalism does not aggravate the principal weakness of the system, for it establishes a historical criterion that is conceptually quite separate from the preferences of the judge himself. And the principal defect of that approach - that historical research is always difficult and sometimes inconclusive - will, unlike nonoriginalism, lead to a more moderate rather than a more extreme result. The inevitable tendency of judges to think that the law is what they would like it to be will, I have no doubt, cause most errors in judicial historiography to be made in the direction of projecting upon the age of 1789 current, modern values - so that as applied, even as applied in the best faith, originalism will (as the historical record shows) end up as something of a compromise." (SCALIA, Antonin. Originalism: the lesser evil, cit., p. 864). No mesmo sentido, TARA SMITH, defensora do originalismo, professora de filosofia da Universidade do Texas, em Austin, a qual afirma que é necessário recorrer à intenção do legislador nos casos difíceis, não devendo o intérprete se ater apenas à linguagem do dispositivo legal: "Authors' intents can be an important part of that. I do not mean to suggest that intent is everything or that the written words are unimportant. The point is simply that words by themselves cannot furnish all that is needed to answer the question that arise in hard cases." (SMITH, Tara. Why originalism won't die - common mistakes in competing theories of judicial interpretation. Duke Journal of Constitutional Law \& Public Policy, vol. 2, 2007, p. 168) 
constitucional, que fosse colocado um fim a esta prática racista.

Na concepção de Dworkin, a interpretação, especialmente nos casos difíceis, exige a consideração de princípios, que se fundamentam na moralidade de uma comunidade política. Os críticos, que consideram antidemocráticas essa prática, partem da premissa que a Democracia significa respeito à vontade da maioria representada pela lei positivada e que, portanto, as restrições impostas à vontade da maioria pelos juízos morais dos juízes, no processo interpretativo da Constituição, a violariam.

A divergência quanto ao que seria a Democracia é muito debatida entre os cientistas e filósofos políticos. A tese que defende que os processos políticos devem ser estruturados de modo a permitir que, nas questões relevantes, a maioria dos cidadãos tenha a última palavra (premissa majoritária) não nega os direitos individuais dos cidadãos, mas defende que o melhor meio de se chegar a eles é pela decisão da maioria.

Em contraposição a esta ideia, Dworkin defende a concepção constitucional de Democracia, na qual se afirma que o objetivo da Democracia deve ser proporcionar condições de igualdade entre os cidadãos, tratando todos com a mesma consideração. Para que isso seja possível, é preciso haver instituições políticas adequadas.

Nesse sentido, Dworkin argumenta que a estrutura política necessária à implementação deste modelo é bem semelhante à estrutura já empregada no modelo majoritário. Todavia, para o filósofo, as semelhanças estruturais não implicam em semelhança de objetivos. A adoção dos processos majoritários, neste sentido, é apenas para melhor instrumentalizar a promoção da igualdade entre os cidadãos, figurando como um meio, não um fim. Assim, 
quando a adoção da decisão majoritária implicar em desigualdade entre os cidadãos, não poderá se opor pela sua manutenção objeções alegando violação do regime democrático, pois este estará sendo devidamente respeitado com a reforma desta decisão. Isto porque, por esta concepção constitucional de Democracia, proposta por Dworkin, as condições democráticas são justamente aquelas que proporcionam igualdade de status a todos os cidadãos.

Uma das críticas centrais que se levantam contra a possibilidade de se recorrer a princípios morais, nos casos difíceis, é a de que os princípios morais não podem ser considerados, em termos objetivos, verdadeiros ${ }^{254}$, pois apenas indicam preferências de uma pessoa ou grupo, não devendo servir de baliza segura para as decisões judiciais em uma Democracia. A ideia de que proposições morais não podem ser consideradas verdadeiras já foi refutada no Capítulo II.3.4. deste trabalho.

Ademais, complementa-se que, para Dworkin, essas afirmações de independência moral no ato decisório não condizem com a prática constitucional, a qual está arraigada de moralidade política. ${ }^{255}$ A resistência a essa influência da moral nas decisões é oriunda da suposta independência entre Moral e Direito, visto que pode não parecer razoável colocar o Direito na dependência dos princípios morais identificados pelos juízes que compõem o órgão julgador em um determinado período. Os juízes, enquanto uma elite intelectual, supostamente, estariam usurpando o poder do povo ao realizar esse

${ }^{254}$ Essa crítica foi tratada com profundidade no Capítulo II.3.4.1. Crítica dos céticos (ceticismo interno e externo)

255 "É evidente que as opiniões dos juízes sobre a moralidade política influenciam suas decisões constitucionais; e, embora fosse fácil para eles explicar essa influência pelo fato de a Constituição exigir uma leitura moral, eles nunca o fazem. Antes, indo contra toda evidência, eles negam a influência e procuram explicar suas decisões de outras maneiras, aliás constrangedoramente insatisfatórias. Dizem, por exemplo, que estão dando eficácia a obscuras "intenções" históricas ou apenas expressando uma "estrutura" constitucional geral porém inexplicada, que supostamente seria compreensível de maneira não-moral." DWORKIN, Ronald. O direito da liberdade: A leitura moral da Constituição norte-americana, cit., p. 5 
tipo de juízo. Por essa perspectiva, a influência da moral em uma decisão judicial seria uma afronta à Democracia, ao poder popular, o que, para Dworkin, não ocorre por inúmeras razões que já foram demonstradas e serão aprofundadas no Capítulo seguinte.

\section{III.3.1. CONCEITOS DE DEMOCRACIA: A CONCEPÇÃo CONSTITUCIONAL, A PREMISSA MAJORITÁRIA E SUA RELAÇÃO COM AS AÇÕES COLETIVAS ESTATÍSTICA E COMUNITÁRIA}

A Democracia ("demos": povo; "cratos": poder/governo) tanto pelo conceito consolidado na teoria política, como pelo seu sentido etimológico, é concebida como o governo do povo. Dworkin esclarece que, embora haja algum consenso quanto a essa concepção, há muita divergência quanto à forma como esse poder irá se operar, isto é, ao que seriam as melhores formas de representação; a distribuição de poder entre os entes da federação; a frequência das eleições; os modos de eleição, dentre outros elementos que favoreceriam a melhor versão de Democracia. Apesar desse debate sobre o melhor arranjo institucional da Democracia, para a teoria de Dworkin, a questão central é conhecer o objetivo fundamental da democracia. Sobre esse objetivo da Democracia, como já foi mencionado no Capítulo supra III.3, há duas correntes importantes, que se contrapõe, quais sejam, a premissa majoritária e a concepção constitucional.

Pela premissa majoritária, defende-se a prevalência da vontade da maioria dos cidadãos nos assuntos importantes da comunidade política como objetivo central da Democracia. Por essa acepção, não importa os resultados concretos que a prevalência dessa vontade produz, pois a ideia de Democracia se esgotaria na observância da vontade da maioria. ${ }^{256}$ Em contraposição a essa

256 DWORKIN, Ronald. O direito da liberdade: A leitura moral da Constituição norte-americana, cit., 
teoria, Dworkin desenvolve a concepção constitucional de Democracia, ${ }^{257}$ na qual defende que o objetivo da Democracia deve ser proporcionar condições de igualdade entre os cidadãos, tratando todos com a mesma consideração e, para que isso seja possível, é preciso haver instituições políticas apropriadas.

A teoria da premissa majoritária alinha-se à concepção separada de Democracia, formulada por Dworkin, na qual se afirma que a Democracia existe se a distribuição do poder político for feita de maneira igualitária, não sendo relevantes os resultados por ela produzidos. Essa concepção:

\begin{abstract}
“(...) faz questão de que julguemos a equidade ou caráter democrático de determinado processo político por meio do exame de características desse processo apenas, só perguntando se ele distribui poder político de maneira igualitária, e não quais resultados ele promete produzir. Uma concepção separada pretende explicar e justificar nossos principais pressupostos acerca da democracia de maneira austera. Assim, ela argumenta que a liberdade de expressão, bem como o sufrágio amplo e irrestrito, ajuda a tornar mais igualitário o poder político, e argumenta que, quando surgem questões controversas acerca de detalhes do nosso processo político, que devemos resolvê-los perguntando qual decisão é a mais bem calculada para aumentar ainda mais a igualdade do poder político.,258
\end{abstract}

Por outro lado, a ideia de Democracia alinhada à concepção constitucional é a Democracia dependente, a qual defende que a verdadeira Democracia é aquela que garante decisões substantivas, assegurando o tratamento igualitário a todos os cidadãos. O foco, por essa perspectiva, está no

\footnotetext{
p. 24

257 "O objetivo que define a democracia tem de ser diferente: que as decisões coletivas sejam tomadas por instituições políticas cuja estrutura, composição e modo de operação dediquem a todos os membros da comunidade, enquanto indivíduos, a mesma consideração e o mesmo respeito." DWORKIN, Ronald. $O$ direito da liberdade: A leitura moral da Constituição norte-americana, cit., p. 26

258 DWORKIN, Ronald. A virtude soberana: A teoria e prática da igualdade, trad. Jussara Simões, São Paulo: Martins Fontes, 2005, p. 256
} 
resultado da decisão e não na igualdade do procedimento adotado, conforme esclarece Dworkin:

"nessa perspectiva, as principais características da democracia - sufrágio quase universal, liberdade de expressão e tudo o mais - justificam-se porque a comunidade na qual o voto é generalizado terá mais probabilidade de distribuir recursos materiais e outras oportunidades e valores de maneira equânime. Portanto, ela recomenda, quando surgirem casos controversos relativos à melhor forma de democracia, que se recorra ao teste consequencialista: qual decisão dessas questões controversas parece mais conducente para promover ou proteger essas metas igualitárias substantivas?"259

A noção de igualdade dos cidadãos, seja por meio dos procedimentos adotados, seja pelos resultados destes, varia conforme a concepção de Democracia. Por uma perspectiva, a Democracia está atrelada à igualdade de participação dos indivíduos no processo político e à legitimidade de fazer valer a vontade da maioria, já que todos tiveram igual oportunidade de participar, ainda que a sua vontade não prevaleça. Em outras palavras, permite que não se trate a todos com igual consideração, se esta for a vontade da maioria, desde que os meios (e.g., o voto) para se formar essa vontade sejam observados. Dworkin esclarece que pela outra perspectiva, ao revés, a Democracia está ligada a ideia de tratar a todos com igual consideração ${ }^{260}$, focando-se nas metas igualitárias substantivas da comunidade política, não sendo relevante, nesse sentido, a vontade da maioria, se esta desejar o tratamento desigual de seus membros (e.g., com a repressão de minorias).

259 DWORKIN, Ronald. A virtude soberana: A teoria e prática da igualdade, cit., pp. 255-256.

260 É de suma importância, na teoria de Dworkin, a ideia de tratar todos com igual consideração, enquanto elemento fundamental de legitimidade das decisões políticas, ou jurídicas, tomadas pelos agentes de poder. Ele repete esta ideia em diversas de suas obras publicadas, e, portanto, não é de se estranhar que em sua obra mais recente, Justice for hedgehogs, novamente, seja reafirmada esta noção: "A political community has no moral power to create and enforce obligations against members unless it treat their fates as equally important and respect their individual responsibilities for their own lives. That principle of legitimacy is the most abstract source of political rights. Government has no moral authority to coerce anyone, even to improve the welfare or well-being or goodness of the community as a whole, unless it respects those two requirements person by person." DWORKIN, Ronald. Justice for hedgehogs, cit., p. 330 
A Democracia, enquanto governo do povo, deve considerar e esclarecer as formas de ação dos cidadãos em conjunto, como forma de expressão da vontade desse povo. A esse propósito, Dworkin esclarece duas formas de ação coletiva, quais sejam, a estatística e a comunitária. A relevância dessa conceituação decorre da possibilidade de verificação de qual delas melhor atende aos objetivos da Democracia.

A ação coletiva estatística é, no entendimento de Dworkin, um conjunto de ações que os indivíduos sem saber que estão agindo, enquanto grupo, praticam. A combinação dessas ações, ainda que independentes, é uma forma de ação conjunta. A esse propósito, um exemplo bastante ilustrativo, formulado por Dworkin, é a queda do preço do dólar em decorrência do mercado de moedas estrangeiras. $\mathrm{O}$ mercado de moedas estrangeiro não é um ente coletivo de fato, mas pode ser afetado por um conjunto de banqueiros e especuladores agindo em um mesmo sentido. Estes indivíduos não percebem que fazem parte de uma coletividade, isto é, não têm consciência que estão agindo em conjunto. ${ }^{261}$

A ação coletiva comunitária, por outro lado, para Dworkin, exige consciência por parte dos indivíduos, uma vez que estes agem por meio de um ente coletivo de fato. A ação coletiva, neste caso, não é o conjunto das ações individuais sem consciência de conjunto, mas se trata efetivamente de uma ação em grupo. Este tipo de ação pode ser exemplificado, de acordo com Dworkin, pelos músicos que compõem uma orquestra. Todos os indivíduos fazem a sinfonia, sendo importantes para que a música seja construída. O violinista, o flautista, o trompetista, o pianista ao lerem sua partitura e sincronicamente

${ }^{261}$ DWORKIN, Ronald, O direito da liberdade: A leitura moral da Constituição norte-americana, cit., p. 33 
reproduzirem o som estão agindo como ente coletivo, uma orquestra. Os músicos têm consciência de que estão agindo em conjunto, assumindo cada um deles a responsabilidade de executar o seu instrumento de maneira harmônica aos demais. A este tipo de ação denomina-se ação coletiva comunitária. ${ }^{262}$

A Democracia, como o governo do povo, em face destes dois conceitos de ação coletiva - estatística e comunitária - enunciados por Dworkin, consubstancia-se no seguinte: (i) por uma interpretação estatística de ação coletiva, as decisões são tomadas por um conjunto de cidadãos considerados individualmente; e (ii) por uma interpretação comunitária, as decisões políticas são tomadas pelo povo, aqui considerado como um ente coletivo distinto de cada um dos indivíduos. Essa distinção entre os tipos de ação coletiva será relevante na análise do princípio da igualdade e suas relações com a Democracia, a ser trabalhada no Capítulo seguinte.

\section{III.3.1.1. AS RELAÇÕES DO PRINCÍPIO DA IGUALDADE COM AS CONCEPÇÕES DE DEMOCRACIA}

O princípio da igualdade, na teoria de Dworkin, é um ideal político que requer a ação do governo no sentido de tratar todos os cidadãos com igual consideração. Todavia, conforme a concepção que é feita do que seria tratar todos com igual consideração, pode-se verificar a violação, ou não, deste ideal, bem como seus reflexos no regime democrático. ${ }^{263}$

262 DWORKIN, Ronald, O direito da liberdade: A leitura moral da Constituição norte-americana, cit., p. 33

263 "Esse princípio estipula que o governo deve agir para melhorar a vida dos cidadãos, com igual consideração pela vida de cada um deles. Chegamos a uma teoria útil e prática sobre o que a igualdade requer, construindo e testando interpretações concretas - concepções - de tal princípio, para decidir qual concepção é, afinal, a melhor. Certamente, o princípio igualitário abstrato não pode decidir tudo: o governo e a política enfrentam uma série de problemas, em todos os níveis de abstração e concretude, que não é possível resolver com uma simples escolha entre as diversas interpretações ou concepções de igualdade abstrata. Não obstante, a influência do princípio igualitário será profunda em qualquer sociedade que o aceite. A interpretação proferida da consideração igualitária influirá não só no projeto de todas as instituições fundamentais do governo, 
Os adeptos da premissa majoritária entendem que a igualdade política fica prejudicada ao se adotar a concepção constitucional de democracia. Entretanto, para que seja possível verificar se essa afirmação de fato se sustenta, é necessário recorrer aos modelos de ação coletiva (estatística e comunitária) apresentados anteriormente.

Como já foi mencionado, por uma perspectiva estatística, formulada por Dworkin, a Democracia é vista como a manifestação da vontade de um conjunto de pessoas, consideradas individualmente, isto é, não vinculadas por uma entidade coletiva distinta. Por essa acepção, a igualdade política deve ser considerada em relação a cada um dos indivíduos, havendo a sua violação caso algum deles não tenha o mesmo direito político que outro. Não se trata de poder político, mas de direitos políticos. $O$ poder político ${ }^{264}$ pode ser diferente entre esses indivíduos, mas todos devem ter os mesmos direitos, a igualdade de pontos de partida na vida política da comunidade. A esse respeito, Dworkin esclarece que:

mas também nas decisões específicas tomadas por essas instituições." DWORKIN, Ronald. A virtude soberana: A teoria e prática da igualdade, cit., p. 253

264 Para Dworkin, o poder político pode ser entendido como uma medida do impacto político de cada um, em outras palavras, o quanto cada indivíduo consegue afetar uma decisão política, a despeito dos outros cidadãos. Por exemplo, uma pessoa que tenha um cargo político (Presidente, Senador, Deputado, Ministro etc.), certamente, consegue fazer valer suas opiniões no campo político mais do que os cidadãos comuns. Esse impacto é decorrente do próprio cargo ocupado dentro da estrutura de poder. Em contrapartida, pode-se entender que o poder político não decorreria do cargo ocupado, mas do quanto cada indivíduo conseguiria, por si mesmo, influenciar as decisões da comunidade, independentemente da posição que ocupa dentro da estrutura de poder. Como poderia ocorrer, por exemplo, com um sujeito que compra várias horas da programação da televisão para disseminar seus ideais, o que a maioria dos indivíduos que compõem a comunidade não pode adquirir. Esse poder econômico possibilita a ele influenciar o pensamento de milhares de pessoas que acompanham a programação. Essa influência, dentro de uma interpretação estatística de democracia, não é desejável, pois a riqueza não é distribuída de maneira homogênea entre os indivíduos. Entretanto, a influência política não decorre somente do poderio econômico, pode advir, por exemplo, da capacidade de convencimento dos indivíduos quando estes conseguem fazer com que os outros concordem com eles e sigam suas ideias. De acordo com Dworkin, essa influência é desejável, todavia, é inegável que ela traria desigualdade política entre os indivíduos, pois uns teriam mais poder político que outros. 
“(...) pelo modelo estatístico de ação coletiva, a igualdade política não pode ser definida em função do poder, mas sim do status de que falei quando tratei das condições de autogoverno democrático. O sufrágio exclusivamente masculino e os votos universitários não eram igualitários porque pressupunham que certas pessoas tinham mais condições ou mais direitos que outras de participar das decisões coletivas. Mas a mera autoridade política - o poder ligado a cargos políticos para os quais todos são, em princípio, elegíveis - não está ligado a nenhum pressuposto desse tipo. É por isso que o poder especial dos ocupantes de cargos públicos não destrói a verdadeira igualdade política (e, quanto a isso, não faz diferença que esses ocupantes sejam eleitos diretamente ou não).,"265

A partir desse entendimento estatístico de ação coletiva, Dworkin defende que os juízes da Suprema Corte ao serem eleitos indiretamente, isto é, por meio dos políticos eleitos pelos cidadãos (indicação pelo Presidente da República e aprovação pelo Senado Federal, por exemplo) não violam, ou prejudicam, a igualdade política destes, ao decidirem os casos difíceis com base na moralidade política de uma comunidade.

Por uma interpretação comunitária de ação coletiva, não se deve considerar os indivíduos isoladamente, mas o ente coletivo distinto - o povo ao se pensar em igualdade política. Pela concepção comunitária, Dworkin afirma que a igualdade política é entendida como o governo do povo, enquanto ente coletivo distinto. ${ }^{266}$ Por esse argumento, poder-se-ia defender que há uma efetiva perda da igualdade política ao se permitir que um Tribunal constitucional dê a última palavra nas questões constitucionais. O Judiciário, ao fazer essa revisão, e declarar determinada norma, criada pelo povo por meio de seus representantes, inconstitucional, e retirá-la do sistema jurídico, faria com que o povo deixasse de governar-se, de modo que o governo passaria a ser do Poder

${ }^{265}$ DWORKIN, Ronald. O direito da liberdade: A leitura moral da Constituição norte-americana, cit., pp. $42-43$

266 DWORKIN, Ronald. O direito da liberdade: A leitura moral da Constituição norte-americana, cit., p. 43 
Judiciário, o que implicaria uma desigualdade política entre o povo (representado pelo Poder Legislativo) e o Judiciário. Esse argumento, todavia, não se sustenta como esclarece Dworkin, porque auto-governo depende da possibilidade de todos terem iguais condições de participação, o que nem sempre implica na prevalência da vontade da maioria, uma vez que pode ser que a maioria reprima uma minoria, retirando-lhes direitos e seu status de igualdade política. Desse modo, a prevalência da premissa majoritária não representa garantia do auto-governo com a preservação da igualdade política entre os cidadãos.

Por todo o exposto, Dworkin entende não haver qualquer violação ou prejuízo da igualdade política ao se preterir a premissa majoritária em favor da concepção constitucional de Democracia.

\section{III.4. OS MODELOS DE COMUNIDADE POLÍTICA E A QUESTÃO DA LEGITIMIDADE}

O ponto que fecha a discussão sobre a legitimidade política é análise da base sobre a qual se assenta essa concepção, isto é, a ideia de comunidade política. Somente é possível analisar a legitimidade política quando ela é vista em perspectiva com a noção de comunidade, isto porque é necessário analisar a vinculação dos cidadãos às decisões tomadas coletivamente por uma comunidade política. Se essas decisões forem legítimas, o cidadão vincula-se; se não forem, não está obrigado a considerá-las. A esse respeito, Dworkin esclarece que:

“(...) a melhor defesa da legitimidade política - o direito de uma comunidade política de tratar seus membros como tendo obrigações em virtude de decisões coletivas da comunidade vai ser encontrada não onde os filósofos esperaram encontrá-la - no árido terreno dos contratos, dos deveres de justiça ou das 
obrigações do jogo limpo, que poderiam ser válidos entre os estranhos -, mas no campo mais fértil da fraternidade, da comunidade e de suas obrigações concorrentes."267

A questão que se coloca a partir da afirmação da legitimidade na ideia de fraternidade da comunidade política é quais características ela deve ter para ser considerada uma comunidade política verdadeiramente fraterna. Para fins de esclarecer esse ponto, Dworkin divide as comunidades políticas em três modelos distintos, quais sejam, o modelo de fato; das regras; e de princípio. ${ }^{268}$

O modelo de fato ocorre quando os membros de uma comunidade se associam em virtude de um evento histórico, geográfico, ou por qualquer outra razão contingencial. Esses membros não se agruparam por terem preferências similares, a mesma língua, religião, gosto musical etc., mas por um elemento externo contingencial. É uma espécie de coexistência pacífica, em que um tolera o outro, porque dadas as circunstâncias é melhor estar junto do que só. Esses membros podem ter empreendimentos comuns, dividir o trabalho, dentre outras coisas, para que a vida de todos fique melhor. De acordo com Dworkin, não há qualquer outro elo que os una de uma maneira verdadeiramente fraternal, é uma relação de troca, que perdurará enquanto for benéfica para esses membros.

O outro modelo de comunidade apresentado pelo filósofo é o modelo de regras, no qual os membros de uma comunidade política aceitam obedecer regras comuns, porque é do interesse individual de cada um fazê-lo. Esses membros não vão além desse espírito individualista, pensam nas regras apenas como um acordo de interesses, que pode favorecê-los mais, ou menos, conforme o caso, não consideram os princípios que fundamentam aquela

267 DWORKIN, Ronald. O império do direito, cit., pp. 249-50

268 DWORKIN, Ronald. O império do direito, cit., p. 252 
comunidade. $^{269}$ Cada um visa ganhar o máximo possível a despeito dos demais membros, sob este aspecto, esse modelo de comunidade adequa-se aos ideais utilitaristas $^{270}$. Os membros da comunidade, fundada no modelo de regras, consideram que têm o dever apenas de respeitar e obedecer às regras expressas que acordaram politicamente, não admitindo qualquer consideração às regras não escritas, que se fundamentem, por exemplo, na moralidade política da comunidade.

O terceiro modelo de comunidade apresentado por Dworkin, a de princípios, concorda com o modelo de regras, na medida em que considera relevante o acordo político que estabelecem as regras, mas dá um passo a frente, ao considerar essencial a uma comunidade política verdadeira o reconhecimento pelos membros desta comunidade de que são governados por princípios comuns, que antecedem e são mais relevantes que as regras. Nesse sentido, Dworkin esclarece que:

\begin{abstract}
"Para tais pessoas, a política tem uma natureza diferente. É uma arena de debates sobre quais princípios a comunidade deve adotar como sistema, que concepção deve ter de justiça, equidade e justo processo legal e não a imagem diferente, apropriada a outros modelos, na qual cada pessoa tenta fazer valer suas convicções no mais vasto território de poder ou de
\end{abstract}

269 "Não consideram que as regras foram negociadas com base em um compromisso comum com princípios subjacentes que são, eles próprios, uma fonte de obrigação; pensam, ao contrário, que essas regras representam um acordo entre interesses ou pontos de vista antagônicos. Se as regras são o produto de uma negociação especial, como no caso do contrato, cada parte tentou ceder o menos possível para obter o máximo possível de retorno, e seria portanto injusto, e não apenas equivocado, que cada uma delas afirmasse que o acordo abrange tudo que não foi explicitamente acordado." DWORKIN, Ronald. O império do direito, cit., p. 254

270 “(...) a maneira mais natural de chegar ao utilitarismo (embora não seja, é óbvio, a única maneira) é adotar para a sociedade como um todo os princípios da escolha racional utilizados por um único ser humano. (...) A natureza da decisão tomada pelo legislador ideal não é, portanto, substancialmente diferente da de um empreendedor que decide como maximizar seus lucros por meio da produção desta ou daquela mercadoria, ou da de um consumidor que decide como maximizar sua satisfação mediante a compra desta ou daquele conjunto de bens. Em cada um desses casos há uma única pessoa cujo sistema de desejos determina a melhor distribuição de meios limitados. A decisão correta é essencialmente uma questão de administração eficiente.” RAWLS, John. Uma teoria da justiça, trad. Alimiro Pisetta e Lenita M. R. Esteves, São Paulo: Martins Fontes, 1997, p. 29 
regras possível. Os membros de uma sociedade de princípio admitem que seus direitos e deveres políticos não se esgotam nas decisões particulares tomadas por suas instituições políticas, mas dependem, em termos mais gerais, do sistema de princípios que essas decisões pressupõem e endossam." ${ }^{271}$

A consideração aos princípios que fundamentam uma comunidade política é relevante à noção de legitimidade, pois somente nesta forma de comunidade, de acordo com a teoria de Dworkin, ter-se-ia uma verdadeira fraternidade entre seus membros que se veem como irmãos de uma empreitada comum, que não se resume aos acordos políticos que são feitos de tempos em tempos e estabelecem novas regras, mas uma empreitada diversa que se perpetua no tempo e se subsidia em princípios políticos fortes que constituem e sustentam aquela comunidade.

Uma comunidade política baseada em princípios, na teoria de Dworkin, requer a observância de algumas condições: a condição de participação moral estrutural e de relação.

As condições de participação moral estrutural, de acordo com Dworkin, são aquelas "que determinam o caráter que a comunidade como um todo tem de ter para que possa ser considerada uma verdadeira comunidade política." 272 Essas condições podem ser históricas como o estabelecimento daquela comunidade enquanto ente coletivo distinto, delimitado por fronteiras territoriais reconhecidas. Poder-se-ia, também, mencionar o compartilhamento de outros elementos, como a língua, cultura, religião etc.

As condições de participação moral de relação "determinam como

${ }^{271}$ DWORKIN, Ronald. O império do direito, cit., pp. 254-55

${ }^{272}$ DWORKIN, Ronald. O direito da liberdade: A leitura moral da Constituição norte-americana, cit., p. 37 
um indivíduo deve ser tratado por uma comunidade política verdadeira para que possa ser um membro moral dessa comunidade. "273 A comunidade política verdadeira deve permitir que o indivíduo participe das decisões coletivas e que seja independente ao tomar sua decisão.

Nesse sentido, Dworkin entende que os indivíduos devem ter, ao menos em potência, a capacidade de interferir em uma decisão coletiva. A medida dessa interferência não está relacionada às preferências do indivíduo, se ele tem boas posições, ou não, se ele tem uma determinada característica, se pertence a uma determinada classe social etc. Pela condição de participação moral de relação, por exemplo, justifica-se a existência do sufrágio universal, a possibilidade dos indivíduos se manifestarem com liberdade, independentemente de qualquer convocação. A liberdade de expressão, na opinião de Dworkin, é o magma da participação no autogoverno, no qual todos, independentemente de sexo, raça ou cor, possam se manifestar de maneira livre e igual. $^{274}$

Além dessa capacidade de interferir na decisão coletiva, a condição de relação exige o tratamento igualitário dos membros da comunidade política, ou seja, deve-se tratar os interesses de todos os membros da comunidade com igual consideração na tomada de decisões. Um indivíduo, para que seja considerado membro moral de uma comunidade política, não basta que se considere nessa condição, é necessário que a comunidade o trate enquanto tal, isto é, que cuide de seus interesses com igual consideração aos dos demais membros daquela comunidade, ainda que ele represente uma minoria. É uma mão de via dupla, o indivíduo, além de se sentir membro de uma comunidade

273 DWORKIN, Ronald. O direito da liberdade: A leitura moral da Constituição norte-americana, cit., p. 37

74 Essa igualdade na liberdade de expressão pode ser reduzida em virtude do poder econômico e ampliada com acesso às mídias virtuais (redes sociais, blogs etc) por um número elevado de pessoas. 
política, deve receber um tratamento adequado desta, pois uma comunidade política que o ignora, ou o menospreza, não é justa, nem legítima, de acordo com a teoria proposta por Dworkin.

Quando há a combinação desses dois elementos - o tratamento igualitário dos membros; e a consideração destes como parte da comunidade política - há a formação de uma associação verdadeira, na qual os membros, ainda que tenham posicionamentos divergentes sobre algumas questões, aceitam as decisões da comunidade.

A presença de posicionamentos divergentes dos membros, associado ao fato destes nem sempre conseguirem fazer prevalecer todos os seus interesses, nos processos decisórios, não implica em uma quebra da comunidade política, porque os membros da comunidade aceitam que algumas decisões sejam tomadas pela coletividade, desde que não deixem de ter o controle sobre os seus gostos, ideologias, preferências individuais etc. Os indivíduos, no pensamento de Dworkin, têm liberdade e, por conseguinte, responsabilidade por decidir seus gostos pessoais, o estilo de vida que mais aprecia e, nem por isso, tornam-se menos independentes ao permitir que a coletividade decida as questões que têm por objetivo balancear os interesses de todos os cidadãos. Um exemplo interessante disso, que Dworkin traz para esclarecer esse ponto, seria o do jogo de futebol, no qual o técnico elabora um determinado plano de ataque, os jogadores discutem a estratégia proposta e, por fim, a maioria dos jogadores concorda em implementar esse plano. Os jogadores que discordaram e manifestaram posicionamentos diversos, também, farão parte da execução do plano proposto pelo técnico, pois são membros morais do time e compartilham do mesmo objetivo comum, que é vencer a partida. Essa situação é bastante diversa daquela em que os jogadores, que tivessem um posicionamento divergente do técnico e do restante do time, não pudessem manifestar a sua 
posição, ou que tivessem de mudar o seu próprio pensamento sobre a questão.

Destaca-se que, na teoria de Dworkin, conforme apontado no exemplo acima elencado, é muito relevante a independência moral dos membros de uma comunidade política, isto é, a liberdade de cada um poder decidir sobre seus valores centrais, seus gostos e preferências particulares. Essas decisões não devem ser objeto de deliberação coletiva, pois se fossem determinadas pela coletividade, não se teria uma comunidade política verdadeira, visto que é condição essencial desta a independência de seus membros. ${ }^{276}$

Se observadas essas condições de participação moral dos indivíduos (estrutural e de relação) na comunidade política de princípios, para Dworkin, tem-se uma comunidade política verdadeiramente fraterna e legítima, a qual exige que o juiz, ao resolver um caso difícil, não se atenha apenas ao conjunto de regras positivadas (comunidade política fundada nas regras), mas que leve em conta os princípios que fundam aquela comunidade política, para que sua decisão de fato possa ser considerada legítima. ${ }^{277}$

${ }^{275}$ DWORKIN, Ronald. O direito da liberdade: A leitura moral da Constituição norte-americana, cit, p. 39

276 “(...) a comunidade política verdadeira é uma comunidade feita de agentes morais independentes. Ela não pode determinar o que seus cidadãos devem pensar a respeito de política ou ética, mas deve, por outro lado, propiciar circunstâncias que lhes permita chegar a crenças firmes em matéria de ética e política através de sua própria reflexão e, por fim, de sua convicção individual." DWORKIN, Ronald. $O$ direito da liberdade: A leitura moral da Constituição norte-americana, cit., p. 40

277 "Uma comunidade de princípios, fiel a essa promessa, pode reivindicar a autoridade de uma verdadeira comunidade associativa, podendo, portanto, reivindicar a autoridade moral - suas decisões coletivas são questões de obrigação, não apenas de poder - em nome da fraternidade. (...) Se podemos compreender nossas práticas como apropriadas ao modelo de princípios, podemos sustentar a legitimidade de nossas instituições, e as obrigações políticas que elas pressupõem, como uma questão de fraternidade, e deveríamos portanto tentar aperfeiçoar nossas instituições em tal direção.” DWORKIN, Ronald. O império do direito, cit., p. 258 


\section{ANÁLISE CASUÍSTICA DA TEORIA APRESENTADA}

Com relação à análise casuística da teoria acima apresentada, destaca-se que não se voltará os olhos, neste Capítulo, para verificar se os juízes aplicaram, ou não, integralmente, Dworkin em suas decisões. Isso porque sequer seria possível, realmente, empreender uma análise neste sentido, na medida em que o processo interpretativo, em sua integridade, supera o que está externado nos votos dos juízes, conforme já foi evidenciado ao longo deste trabalho. Por essa razão, para não se incorrer em simplificações equivocadas do processo interpretativo e, por conseguinte, da própria teoria de Dworkin, optou-se por analisar trechos de votos dos ministros do Supremo Tribunal Federal brasileiro, nos quais se menciona, expressamente, a teoria de Dworkin, em algum de seus aspectos, para fundamentar certas posições dos ministros.

Ressalta-se que o objetivo aqui, além de demonstrar a relevância deste autor ao direito brasileiro, é analisar o que está em jogo nas decisões e a posição adotada pelos ministros, que prestigiam aspectos da teoria proposta por Dworkin.

Quanto ao critério utilizado para selecionar os casos, esclarece-se que foram relacionados aqueles cujos votos fazem menção expressa a Dworkin, conforme sistema de busca por palavras-chave disponibilizado no sítio eletrônico oficial do Supremo Tribunal Federal ${ }^{278}$. Ou seja, todos os votos em que se menciona Dworkin, expressamente, conforme apontado pelo sistema de busca, serão aqui analisados. Totalizam-se sete casos práticos ${ }^{279}$, aos quais serão

\footnotetext{
${ }^{278}$ Sistema de busca disponível em: http://www.stf.jus.br/portal/jurisprudencia/pesquisarJurisprudencia.asp. Acesso em: 18 de novembro de 2012.

279 ADPF 132; ADFP 130; Adin 3.510/DF; $\mathrm{HC}$ n. ${ }^{\circ} 84.025-6 / \mathrm{RJ} ; \mathrm{HC}^{\circ} .^{\circ} 84.078-7 / \mathrm{MG}$; Medida Cautelar na Adin n. ${ }^{\circ}$ 4.264/PE; MS n. ${ }^{\circ}$ 26.602/DF; 26.603/DF; e 26.604/DF (sendo estes três Mandados de Segurança julgados em conjunto pelo STF)
} 
dados mais, ou menos, destaque conforme a relevância do aspecto abordado da teoria de Dworkin atinente ao tema deste trabalho.

(i.) O primeiro caso a ser tratado é a Arguição de Descumprimento de Preceito Fundamental 132 (“ADPF 132”) ${ }^{280}$, proposta pelo governador do Estado do Rio de Janeiro, julgada em 05 de maio de 2011, e relatada pelo Ministro Carlos Ayres Britto. O ponto central trazido pelo requerente à apreciação de constitucionalidade foi o tratamento diferenciado, redutor de direitos das pessoas com preferência, ou concreta orientação homossexual, dado pelo Poder Judiciário, com base em dispositivos do Estatuto dos Servidores Civis do Estado do Rio de Janeiro (Decreto-lei 220/1975), no que se refere aos direitos às licenças (art. 19, incisos II e V, Decreto-lei 220/1975), à previdência e à assistência (art. 33, incisos I a X, Decreto-lei 220/1975) dos servidores civis estaduais. Esta interpretação reducionista dos referidos dispositivos do Estatuto, a qual não equipararia as uniões homoafetivas às uniões heterossexuais, seria violadora dos dispositivos constitucionais que consagram a igualdade (art. $5^{\circ}$, caput, CF), a segurança jurídica (art. 5 , caput, CF); a liberdade (art. 5º II, CF); e, por fim, a dignidade da pessoa humana (art. $1^{\circ}, \mathrm{IV}, \mathrm{CF}$ ). $\mathrm{O}$ requerente postulou, igualmente, que as uniões estáveis homoafetivas fossem equiparadas às uniões estáveis heteroafetivas, aplicando-se o método analógico de integração do Direito ao art. 1.723 do Código Civil ${ }^{281}$, o que ampliou o escopo da ação proposta a todos que dela possam se beneficiar.

A ação foi julgada procedente, por votação unânime, com eficácia

\footnotetext{
280 Houve a encampação dos fundamentos desta ADPF pela ADI n. ${ }^{\circ}$ 4227-DF, para que se pudesse fazer a "interpretação conforme à Constituição" do art. 1723 do Código Civil (conforme o item 1, da ementa do julgado), disponível em: http://redir.stf.jus.br/paginadorpub/paginador.jsp?docTP=AC\&docID=628633, acessado em 19 de novembro de 2012.

281 Art. 1.723. É reconhecida como entidade familiar a união estável entre o homem e a mulher, configurada na convivência pública, contínua e duradoura e estabelecida com o objetivo de constituição de família.
} 
erga omnes e efeito vinculante, ou seja, asseguraram-se, em todo o território nacional, às uniões homoafetivas o mesmo tratamento dirigido às uniões heteroafetivas pela legislação vigente, sendo esta a interpretação conforme a Constituição consignada pelo Supremo Tribunal Federal. Passa-se a analisar em como a teoria proposta por Dworkin serviu de argumento a essa decisão.

O ministro Ayres Britto citou Dworkin, em seu voto ${ }^{282}$, para fundamentar a igualdade, consubstanciada no direito à "igual consideração" no tratamento das pessoas, que deve ser proporcionado pelo Estado, independentemente da preferência, ou da orientação sexual, que elas venham a ter. A tese de se tratar as pessoas com igual consideração é central na teoria de Dworkin, enquanto elemento fundamental de uma verdadeira Democracia (concepção constitucional de Democracia). A vontade da maioria, externada por meio de leis, que podem segregar, ou criar tratamentos diferenciados injustificáveis entre as pessoas, pode e deve ser sempre corrigida pelo Poder Judiciário, o qual tem papel fundamental no zelo da Constituição e, por conseguinte, da própria Democracia enquanto tal. O argumento de se tratar todos com igual consideração formulado por Dworkin e mencionado pelo ministro Ayres Britto, em seu voto, foi tratado com a devida profundidade nos Capítulos III.3. e III.4. desta dissertação. A esse respeito, apenas reitera-se que é uma condição de participação moral de relação, em uma comunidade política legítima, que os indivíduos sejam tratados com igual consideração por esta. Nesse sentido, qualquer distinção fundada em uma escolha da esfera pessoal do indivíduo (e.g., orientação sexual), que implique em uma restrição legal de

\footnotetext{
282 "Não se pode ceder, no caso, a considerações de ordem moral, exceto por uma, que, ao revés, é indispensável: todos os indivíduos devem ser tratados com igual consideração e respeito. É esta a base da leitura moral da Constituição propugnada por RONALD DWORKIN (Freedom's Law: The Moral Reading of The American Constitution. Cambridge: Harvard University Press, p. 7-8), que, mesmo tecendo argumentos sobre o constitucionalismo nos EUA, formula assertivas perfeitamente aplicáveis ao direito constitucional brasileiro." ADPF 132, voto no Ministro Carlos Ayres Britto, p. 65
} 
direitos é antidemocrática e, consequentemente, ilegítima na teoria proposta por Dworkin.

Por último, quanto a este caso, traça-se uma distinção elucidativa, sobre a concepção do Direito como integridade para Dworkin e o originalismo. Conforme já explanado no Capítulo III.3, os originalistas têm como fio condutor de suas decisões a intenção concreta do legislador ao positivar um certo dispositivo legal, de modo que qualquer interpretação que viole essa intenção seria inadequada e impertinente ao Poder Judiciário. Nessa toada, um originalista fiel não daria a decisão que o Supremo Tribunal Federal consagrou, ao revés, afirmaria que a vontade do legislador é manifesta e não deveria ter sido tergiversada pelos juízes, ao interpretar o art. 1.723 do Código Civil e não respeitar a expressão homem (gênero masculino) e mulher (gênero feminino) do referido artigo. Diria que essa decisão cabe ao legislador e não ao Judiciário sob pena de se violar a separação dos Poderes. Todavia, como foi evidenciado neste trabalho, o Judiciário tem o papel de defender as minorias contra a vontade da maioria eventual, tem o papel precípuo na defesa de que todas as pessoas sejam tratadas com igual consideração, e este princípio está acima de qualquer regra que estabeleça desigualdades injustificadas. O caso da equiparação da união homoafetiva à união heteroafetiva, considerando-a como uma entidade familiar, nos termos do art. 1.723 do Código Civil, é uma questão de princípio que supera a terminologia adotada pelo legislador ao formular a sua regra.

(ii.) O segundo caso que se irá analisar é a Arguição de Descumprimento de Preceito Fundamental 130 (“ADPF 130”) ${ }^{283}$, relatada pelo Ministro Carlos Ayres Britto, proposta pelo Partido Democrático Trabalhista (“PDT”), referente à Lei de Imprensa (Lei 5.250/1967). O requerente

${ }^{283}$ Disponível em: http://redir.stf.jus.br/paginadorpub/paginador.jsp?docTP=AC\&docID=605411, acessado em 19 de novembro de 2012 
questionava, a princípio, a não-recepção de alguns dispositivos da Lei de Imprensa pela Constituição Federal de 1988, e requeria a interpretação conforme a esta de outros dispositivos; alegando violação aos seguintes artigos constitucionais: art. 5', incisos IV, V, IX, X, XIII e XIV ${ }^{284}$, e dos arts. 220 a $223^{285}$, da Constituição Federal. Houve uma modificação dos pedidos, no curso da ação, tendo o arguente requerido a declaração de invalidade jurídica da Lei de Imprensa, em sua totalidade, sob o argumento de que esta seria incompatível à Democracia. Caso o Supremo Tribunal Federal não entendesse ser este o caso, requereu, alternativamente, que fosse declarada a não-recepção de inúmeros dispositivos da referida lei. Não se irá aqui listar quais eram as dezenas de dispositivos arguidos incompatíveis à Constituição, até mesmo porque o foco está na análise do que está em jogo, em termos principiológicos, e em que Dworkin ajudou a formular posições de ministros. O confronto formado tem dois frontes, quais sejam, a liberdade de imprensa, de um lado, e os direitos de imagem, honra, intimidade e vida privada, de outro. A esse respeito, vale ressaltar que a Lei de Imprensa, em questão, foi promulgada em plena ditadura militar e, portanto, não é de se esperar que reverencie, adequadamente, a

284 Art. 5. IV- é livre a manifestação do pensamento, sendo vedado o anonimato; V - é assegurado o direito de resposta, proporcional ao agravo, além da indenização por dano material, moral ou à imagem; (...) IX - é livre a expressão da atividade intelectual, artística, científica e de comunicação, independentemente de censura ou licença; X - são invioláveis a intimidade, a vida privada, a honra e a imagem das pessoas, assegurado o direito a indenização pelo dano material ou moral decorrente de sua violação; (...)XII - é livre o exercício de qualquer trabalho, ofício ou profissão, atendidas as qualificações profissionais que a lei estabelecer; XIV - é assegurado a todos o acesso à informação e resguardado o sigilo da fonte, quando necessário ao exercício profissional.

285 Art. 220. A manifestação do pensamento, a criação, a expressão e a informação, sob qualquer forma, processo ou veículo não sofrerão qualquer restrição, observado o disposto nesta Constituição. (...) Art. 221. A produção e a programação das emissoras de rádio e televisão atenderão aos seguintes princípios: I - preferência a finalidades educativas, artísticas, culturais e informativas; II - promoção da cultura nacional e regional e estímulo à produção independente que objetive sua divulgação; III regionalização da produção cultural, artística e jornalística, conforme percentuais estabelecidos em lei; e IV - respeito aos valores éticos e sociais da pessoa e da família. Art. 222. A propriedade de empresa jornalística e de radiodifusão sonora e de sons e imagens é privativa de brasileiros natos ou naturalizados há mais de dez anos, ou de pessoas jurídicas constituídas sob as leis brasileiras e que tenham sede no País. (...) Art. 223. Compete ao Poder Executivo outorgar e renovar concessão, permissão e autorização para o serviço de radiodifusão sonora e de sons e imagens, observado o princípio da complementaridade dos sistemas privado, público e estatal. 
liberdade de expressão ${ }^{286}$.

A ação foi julgada procedente, em 30 de abril de 2009, por maioria de votos, pelo Supremo Tribunal Federal, vencido, integralmente, o Ministro Marco Aurélio, e, em parte, os Ministros Joaquim Barbosa e Gilmar Mendes, e a Ministra Ellen Gracie. Ou seja, o tribunal priorizou a defesa da liberdade de imprensa em face dos direitos de imagem, honra, intimidade e vida privada, conforme estipulado na Lei de Imprensa. Esses direitos personalíssimos (honra, intimidade, vida privada etc) continuaram a ser protegidos, mas não nos termos da herança do regime militar, manifesta na Lei de Imprensa. Os direitos personalíssimos mencionados passaram a encontrar resguardo na Constituição Federal, no Código Penal, e no Código Civil.

Dworkin foi mencionado no voto Ministro Menezes Direito, o qual conclui que uma lei, que regula a liberdade de expressão, promulgada em pleno regime militar não merece guarida em um regime democrático estabelecido pela Constituição de 1988. A menção a Dworkin é para firmar duas de suas posições: (i) a primeira delas ${ }^{287}$ é a de que a imprensa desenvolve um

286 De acordo com notícia veiculada no sítio eletrônico oficial do Senado Federal: "Datada de 9 de fevereiro de 1967, a Lei de Imprensa (Lei 5.250), que regulava a liberdade de manifestação do pensamento e de informação, foi assinada pelo general Humberto de Alencar Castello Branco, então Presidente da República, com o objetivo de restringir as atividades da imprensa e punir jornalistas e veículos de comunicação que se opusessem ao regime militar.” (g.n.) Disponível em: http://www12.senado.gov.br/noticias/entenda-o-assunto/lei-de-imprensa. Acesso em: 24 de novembro de 2012

287 "E, ainda, lembrei Dworkin, que mostrou com pertinência que tanto a imprensa quanto o Estado sofreram desenvolvimento no seu modo de operação. Escreveu Dworkin que "as duas instituições aumentaram seu poder juntas, numa espécie de simbiose constitucional: a influência da imprensa decorre em grande parte da justificada crença do público de que uma imprensa livre e poderosa serve para impor bem-vindas restrições às atitudes de segredo e desinformação por parte do Estado. A intenção mais básica dos autores da Constituição era a de criar um sistema equilibrado de restrições ao poder: o papel político da imprensa agindo dentro de uma imunidade limitada em relação aos seus próprios erros, parece agora um elemento essencial desse sistema - pelo fato mesmo de a imprensa ser a única instituição dotada de flexibilidade, do âmbito e da iniciativa necessárias para descobrir e publicar as mazelas secretas do Executivo, deixando a cargo das outras instituições do sistema a tarefa de saber o que fazer com essas descobertas" (O direito da liberdade, Martins Fontes, 2006, pág. 300)." Voto do Ministro Menezes Direito, ADPF 130/DF, pp. 85-86 
importante papel no controle do poder do Estado, especialmente, do Poder Executivo, por meio de investigação e divulgação de informações, que revelam ilegalidades perpetradas na surdina e que, provavelmente, nunca seriam descobertas se não fosse por ação dela; por isso, mostra-se muito relevante mantê-la livre e sem má-fé, com espírito de bem informar a população; e (ii) a segunda posição firmada pelo Ministro, inspirado em Dworkin, refere-se a questão do direito à indenização, em razão de matéria jornalística veiculada ${ }^{288}$. A esse respeito, o Ministro remete ao famoso caso norte-americano New York Times vs. Sullivan, citado por Dworkin, e defende que apenas deve ser devida indenização se houver descuido, negligência e má-fé por parte do jornalista, que, como qualquer outro profissional, deve ser responsabilizado nestes casos. Nesse sentido, a ação dos jornalistas, em respeito à liberdade de expressão que lhes é assegurada, deve ser orientada pela boa-fé, e não pela maledicência, ou pelo medo de ser reprimido injustamente.

Dworkin, como um bom norte-americano, é um grande defensor da liberdade. O Ministro Menezes Direito cita trechos interessantes de sua obra, aplicando-os à realidade brasileira. Ressalta-se que o Brasil, embora tenha uma tradição mais intermitente quanto a este valor, especialmente, em razão da sua experiência histórica, com o regime militar, mostrou, por meio da sua Corte Constitucional, que a comunidade política brasileira avança nos trilhos de uma liberdade de imprensa responsável, que somente deve sofrer restrições quando

288 "O regime constitucional nascido com a Constituição de 1988 não se compadece com outra forma de mediação do Estado. Veja-se ainda uma vez a lição extraída por Dworkin no caso New York Times vs. Sullivan em torno da Primeira Emenda no sentido de que o voto do Juiz Brennnan "dá a moderna fundamentação do direito de liberdade de expressão nos Estados Unidos" (op. cit., pág. 312). É que naquela decisão criou-se limitação quanto à prova para que os agentes públicos pudessem receber indenização, cabendo-lhes provar a existência de "malícia efetiva", isto é, a prova de que os "jornalistas não só foram descuidados ou negligentes ao fazer as pesquisas para a reportagem, mas que também a publicaram sabendo que ela era falsa ou com temerária desconsideração' (reckless disregard) pela veracidade ou falsidade das informações ali contidas" (op. cit., pág. 311). É claro que muitas vezes há a veiculação do mal, mas isso não se deve à liberdade de imprensa e sim à qualidade do profissional, como ocorre em qualquer atividade humana" Voto do Ministro Menezes Direito, ADPF 130/DF, pp. 93-94 
age com descuido, negligência e má-fé. Ainda destaca-se que, como já esclarecido neste trabalho, os valores devem ser interpretados de maneira integrada (Capítulo II.2.), isto é, o intérprete deve considerar o conjunto de valores que compõem o Direito como integridade. O Supremo Tribunal Federal ao afastar a aplicação da lei de imprensa, privilegia essa visão integrada de valores, de modo a deixá-los todos sob sua melhor luz, porquanto, tanto o direito à liberdade de expressão, como os direitos personalíssimos (à honra, à imagem, à vida privada etc) restaram assegurados, sem haver um tratamento desmedido entre eles conforme a herança do regime militar.

Por fim, salienta-se que este caso serve para ilustrar que, como propõe Dworkin (Capítulo II.3.1., desta dissertação), não há um dever de coerência com todas as partes da história de uma comunidade política, deve-se privilegiar uma visão holística, integrada, que permita romper com uma parte da história (censura à imprensa promovida pelo regime militar, fundada na Lei de Imprensa) que não se mostra mais adequada com a conjuntura atual.

(iii.) O terceiro caso que se irá analisar trata-se da Ação Direta de Inconstitucionalidade n. 3.510 ("Adin 3.510/DF") ${ }^{289}$, relatada pelo Ministro Carlos Ayres Britto, proposta pelo Procurador Geral da República, em face da Lei de Biossegurança (Lei n. ${ }^{\circ}$ 11.105/2005). Em suma, questionava-se a constitucionalidade do art. $5^{\mathbf{o}^{290}}$, da referida lei, o qual estabelecia condições

${ }^{289}$ Disponível em: http://redir.stf.jus.br/paginadorpub/paginador.jsp?docTP=AC\&docID=611723. Acesso em: 30 de novembro de 2012.

290 "Art. $5^{\circ}$. É permitida, para fins de pesquisa e terapia, a utilização de células-tronco embrionárias obtidas de embriões humanos produzidos por fertilização in vitro e não utilizados no respectivo procedimento, atendidas as seguintes condições: I - sejam embriões inviáveis; ou II - sejam embriões congelados há 3 (três) anos ou mais, na data da publicação desta Lei, ou que, já congelados na data da publicação desta Lei, depois de completarem 3 (três) anos, contados a partir da data de congelamento. $\S 1{ }^{\mathrm{O}} \mathrm{Em}$ qualquer caso, é necessário o consentimento dos genitores. § 2 - Instituições de pesquisa e serviços de saúde que realizem pesquisa ou terapia com células-tronco embrionárias humanas deverão submeter seus projetos à apreciação e aprovação dos respectivos comitês de ética em pesquisa. § 3 OÉ vedada a comercialização do material biológico a que se refere este artigo e sua 
para “a utilização de células-tronco embrionárias obtidas de embriões humanos produzidos por fertilização in vitro e não utilizados no respectivo procedimento”, sob o argumento de que violaria o direito à vida, partindo do pressuposto que o embrião humano é uma vida humana e, por conseguinte, merecedor da mesma proteção a esta assegurada pela Constituição.

A ação foi julgada improcedente, por maioria de votos, em 29 de maio de 2008, tendo sido vencidos, parcialmente, em diferentes partes, os Ministros Menezes Direito, Ricardo Lewandowski, Eros Grau, Cezar Peluso e Gilmar Mendes.

Dworkin foi citado por cinco Ministros em seus votos: Ministros Carlos Ayres Britto; Menezes Direito; Ricardo Lewandowski, Gilmar Mendes e Ministra Cármen Lúcia. Os Ministros privilegiaram, em seus votos, diferentes aspectos da teoria de Dworkin.

Com relação ao Ministro Ayres Britto, ele menciona a obra de Dworkin para firmar as seguintes posições: (i) o Direito protege de maneira diferenciada cada um dos estágios da biologia humana ${ }^{291}$, por exemplo, uma pessoa morta recebe menos proteção do ordenamento jurídico que uma pessoa viva, e, do mesmo modo, deve ser encarada a proteção de um embrião humano, que não deve ser a mesma dirigida a uma pessoa já constituída, titular de

prática implica o crime tipificado no art. 15 da Lei no-9.434, de 4 de fevereiro de 1997."

291 "Convergentemente, essa constatação de que o Direito protege por modo variado cada etapa do desenvolvimento biológico do ser humano é o próprio fio condutor de todo o pensamento de Ronald Dworkin, constitucionalista norte-americano, exposto ao longo das 347 páginas do seu livro "Domínio da Vida" (Editora Martins Fontes, São Paulo, 2003). Proteção que vai aumentando à medida que a tais etapas do evolver da criatura humana vai-se adensando a carga de investimento nela: investimento natural ou da própria natureza, investimento pessoal dos genitores e familiares. É o que se poderia chamar de tutela jurídica proporcional ao tamanho desse investimento simultaneamente natural e pessoal, dado que também se faz proporcionalmente maior a cada etapa de vida humana a carga de frustração com a falência ou bancarrota do respectivo processo (a curva ascendente e de expectativas somente se transmuta em descendente com a chegada da velhice)" Voto Ministro Celso Ayres Britto, Adin 3.510/DF, pp. 167-168 
personalidade pelo Direito; e (ii) a de que o embrião in vitro não mantém o mesmo vínculo físico e afetivo, com seus genitores, que o embrião convencional concebido in natura. Esclarece o Ministro, em referência a Dworkin, que a relação que a gestante estabelece com a vida que cresce dentro dela é muito diversa da relação com o embrião congelado em laboratório, ainda que dela proveniente, este representaria apenas um início de uma trajetória, a qual pode redundar em uma vida, se implantado em um útero, ou continuar congelado em uma "urna mortuária", a qual seria o "absoluto e terrível colapso da luz"292, recorrendo o Ministro a metáfora enunciada por Dworkin.

Quanto ao voto do ministro Menezes Direito, ele reitera a primeira posição firmada pelo Ministro Ayres Britto, com base no pensamento de Dworkin, qual seja, a diferente proteção do ordenamento jurídico aos diferentes estágios biológicos do desenvolvimento da vida humana. Ele cita ipsis litteris o trecho do voto do relator, Ministro Ayres Britto. ${ }^{293}$

A Ministra Cármen Lúcia preferiu não repetir o relator no aspecto abordado da teoria de Dworkin. Ela, em referência ao filósofo norte-americano,

292 "Realmente, o feto é organismo que para continuar vivo precisa da continuidade da vida da gestante. Não subsiste por conta própria, senão por um átimo. Cresce dentro de um corpo que também cresce com ele. Pulsa em par com outra pulsação e respira igualmente a dois. Não sabe o que é solidão, porque desmente a lei da Física de que dois corpos não podem ocupar ao mesmo tempo o mesmo espaço. Se desde os seus primeiros sinais de formação neural já reconhece a voz e o riso de quem o transporta e alimenta, quem o transporta e alimenta fica para sempre com o seu retrato sentimental na parede do útero. Impossível esquecê-lo! Se o homem esgota o seu constitutivo papel na formação de um novo ser com o ato em si da produção do sêmen fecundante, a mulher não exaure esse papel com a produção do óvulo fecundado. Esse ovócito ou célula-ovo é apenas o início de uma trajetória intestina que tanto pode dar no esplendor da vida cá de fora, passando pelo útero, naturalmente, como acabar na escuridão de uma urna mortuária ("o absoluto e terrível colapso da luz", na precisa metáfora do mesmo Ronald Dworkin, página 280 do seu precioso livro). Se a partir de um certo período de vida o feto experimenta o que os teólogos chamam de animação ou presença da alma, essa alma junta-se à da parturiente para um tipo de coabitação tão inescapável quanto aquela de ordem corporal.” (g.n.) Voto Ministro Celso Ayres Britto, Adin 3.510/DF, p. 190

293 “"(v) sobre a existência de graus diversos de proteção do ser humano: "25. Convergentemente, essa constatação de que o Direito protege por modo variado cada etapa do desenvolvimento biológico do ser humano é o próprio fio condutor de todo o pensamento de Ronald Dworkin, constitucionalista norte-americano (...)"." Voto do Ministro Menezes Direito, Adin 3.510/DF, p. 227 
menciona que, embora o embrião não seja titular de personalidade pelo Direito, é dotado de humanidade, assim como o morto, e por isso deve receber a devida proteção jurídica. Nesse ponto, remete a ideia de dignidade humana, que se estenderia a todos aqueles dotados de humanidade (pessoa morta, embrião humano etc), independentemente, de serem considerados titulares de personalidade jurídica pelo ordenamento. ${ }^{294}$

Com relação ao voto do Ministro Ricardo Lewandowski, ele apenas faz uma referência breve a Dworkin, enquanto um dos precursores da diferença entre regras, princípios e postulados, estabelecida por Humberto D’Ávila. ${ }^{295}$ Ressalta-se, a esse respeito, que Dworkin não elabora a distinção entre princípios, regras e postulados, mas princípios, regras e políticas, conforme esclarecido no Capítulo II.1.3, desta dissertação.

Por último, o Ministro Gilmar Mendes, em seu voto, destaca um importante aspecto da teoria de Dworkin ${ }^{296}$, mencionado neste trabalho, nos

294 "Significa que o princípio constitucional da dignidade humana estende-se além de cada pessoa, considerando todos os seres humanos, os que compõem a espécie, dotam-se de humanidade, ainda quando o direito sequer ainda reconheça (ou reconheça precariamente, tal como se tem na fórmula da Convenção Nacional de Ética francesa de pessoa humana em potencial) a personalidade. É o que se dá com o embrião e com o morto, que não dispõe das condições necessárias para titularizar a personalidade em direito (pelo menos em todas as legislações vigentes, hoje, no mundo), mas que compõem a humanidade e são protegidos pelo direito pela sua situação de representação da humanidade." Neste trecho a ministra insere ao final a nota de rodapé 7. "Nota 7. Ronald Dworkin salienta a sacralidade da dignidade da vida, construindo vasto e fecundo trabalho sobre o seu domínio, no qual expõe que "A segunda afirmação que se pode fazer mediante o uso da conhecida retórica é muito diferente: a vida humana tem um valor intrínseco e inato; a vida humana é sagrada em si mesma; o caráter sagrado da vida humana começa quando sua vida biológica se inicia, ainda antes de que a criatura à qual essa vida é intrínseca tenha movimento, sensação, interesses ou direitos próprios. ... Se as grandes batalhas sobre o aborto e a eutanásia são realmente travadas em nome do valor intrínseco e cósmico da vida humana, como acredito que o sejam, então essas batalhas têm ao menos uma natureza quase religiosa, e não chega a surpreender que muitas pessoas acreditem que o aborto e a eutanásia sejam profundamente condenáveis e, ao mesmo tempo, que não cabe ao governo tentar estigmatizá-los com a força bruta das leis penais" (DWORKIN, Ronald - Op. cit., p.18).” Voto da Ministra Cármen Lúcia, Adin 3.510/DF, p. 360 e p. 370

295 "Humberto D'Ávila, com arrimo nas idéias de Karl Larenz, Ronald Dworkin e Robert Alexy, dentre outros, distingue três modalidades de normas jurídicas: as regras, os princípios e os postulados." Voto Ministro Ricardo Lewandowski, Adin 3.510/DF, p. 413

296 "Muito se comentou a respeito do equívoco de um modelo que permite que juízes, influenciados por 
Capítulos III.1. e III.3., a respeito do papel do Poder Judiciário, enquanto uma instituição contra-majoritária, a qual faz valer a Constituição, a despeito da vontade da maioria. Para o Ministro, respaldado na teoria de Dworkin, deixar decisões desta envergadura submetidas à vontade da maioria não produz melhores decisões, tampouco se pode considerar que estas seriam mais democráticas. Neste ponto, reitera-se que para Dworkin, Democracia não se confunde com vontade da maioria, trata-se, na verdade, de um conceito que exige que todos sejam tratados com igual consideração, o que a experiência indica ser mais bem realizado pelo Judiciário, enquanto instituição contramajoritária, zeladora da Constituição.

Cumpre elucidar e aprofundar, com relação ao trecho do voto do Ministro Gilmar Mendes, ora mencionado, que Dworkin não entende ser papel do Judiciário adentrar em questões filosóficas, ou de ordem religiosa, sobre qual seria o início, o conceito de vida, a existência de alma no feto, dentre outras questões que aqui se poderia levantar, mas a correta interpretação da Constituição quanto à proteção dirigida ao feto. Ao discutir o emblemático caso sobre a possibilidade de aborto até o primeiro trimestre de gestação (Roe vs. Wade $^{297}$ ), Dworkin afirma que a submissão desta questão ao legislativo seria um erro, pois a questão é de cunho evidentemente jurídico. Explica-se: para ele, deve-se interpretar a Constituição de modo a saber se o feto é, ou não, pessoa constitucional, isto é, se deve ser tratado com a mesma consideração que os

suas próprias convicções morais e religiosas, dêem a última palavra a respeito de grandes questões filosóficas, como a de quando começa a vida. Lembro, em contra-argumento, as palavras de Ronald Dworkin que, na realidade norte-americana, ressaltou o fato de que "os Estados Unidos são uma sociedade mais justa do que teriam sido se seus direitos constitucionais tivessem sido confiados à consciência de instituições majoritárias". Em nossa realidade, o Supremo Tribunal Federal vem decidindo questões importantes, como a recente afirmação do valor da fidelidade partidária (MS ${ }^{\circ}$ 26.602, 26.603 e 26.604), sem que se possa cogitar de que tais questões teriam sido melhor decididas por instituições majoritárias, e que assim teriam maior legitimidade democrática." Voto do Ministro Gilmar Ferreira Mendes, Adin 3.510/DF, pp. 597-598

297 DWORKIN, Ronald. O direito da liberdade: A leitura moral da Constituição norte-americana, cit., pp. $70-72$ 
outros indivíduos, afirmando, a esse respeito, que "é uma questão complexa e difícil e de fato envolve problemas de moral. Não obstante, é diferente da questão metafísica debatida pelos filósofos e teólogos; não há incoerência nenhuma em se pensar, por exemplo, que um feto é tão ser humano quanto um adulto ou que ele tem alma desde a concepção, e que mesmo assim a Constituição, segundo a melhor interpretação que podemos dar, não garante ao feto os mesmos direitos que garante a outras pessoas. "298

(iv.) Passa-se a análise do quarto caso, o Habeas Corpus $n .^{\circ}$ 84.025-6/RJ ${ }^{299}$, de relatoria do Ministro Joaquim Barbosa, julgado em 04 de março de 2004. O habeas corpus era de natureza preventiva, pleiteava-se a concessão de ordem, para que a paciente pudesse fazer aborto de feto anencefálico, o qual gestacionava, sem incorrer no crime insculpido no art. 124, do Código Penal.

Os ministros do Supremo Tribunal Federal julgaram, por unanimidade, prejudicado o habeas corpus, tendo em vista que a gestante deu à luz antes do julgamento do writ.

O Ministro Joaquim Barbosa, embora tenha julgado prejudicado o writ, fez importantes considerações quanto ao mérito das questões envolvidas no referido caso. Esclarece que o caso envolve o embate entre o direito à vida, em sentido amplo, e o direito à liberdade, à intimidade e à autonomia privada da mulher, em sentido estrito. Para firmar a sua posição, esclarece que, considerando que o feto anencefálico não tem chance de vida extrauterina, o direito à vida, constitucionalmente assegurado, deveria ceder espaço ao direito à

298 DWORKIN, Ronald. O direito da liberdade: A leitura moral da Constituição norte-americana, cit., p. 71

299 Disponível em: http://redir.stf.jus.br/paginadorpub/paginador.jsp?docTP=AC\&docID=384874. Acesso em: 03 de dezembro de 2012. 
liberdade, à intimidade e à autonomia privada da mulher, pessoa também protegida constitucionalmente. Nesse sentido, ela não deveria ser obrigada a gestacionar um feto, que comprovadamente, por laudos médicos, não vingará. $\mathrm{O}$ Ministro Joaquim Barbosa para reforçar essa posição menciona lição de Dworkin, a qual defende que o controle sobre o corpo da mulher gera uma séria lesão à sua liberdade, caracterizando uma servidão parcial, absolutamente indevida. ${ }^{300}$ Trata-se de um embate, entre o direito à vida do feto anencefálico e o direito à liberdade, à intimidade e à autonomia privada da mulher, cuja leitura da Constituição e dos precedentes, realizada pelo Ministro Joaquim Barbosa, evidencia a sua preocupação em construir a sua decisão, de maneira coerente e integrada, como orienta Dworkin na sua teoria da decisão judicial.

É interessante observar que, tanto no presente caso, como no da Adin 3.510/DF, cujas temáticas envolvem a questão da proteção à vida, os Ministros do Supremo Tribunal Federal mencionaram Dworkin, pinçando diversos aspectos de sua teoria, o que mostra o prestígio deste autor ao tratar de casos difíceis relacionados ao direito à vida em suas obras.

(v.) O quinto caso que irá analisar é o Habeas Corpus n. ${ }^{\circ} 84.078$ $7 / \mathrm{MG}^{301}$, de relatoria do Ministro Eros Grau, julgado em 05 de fevereiro de 2009, referente à possibilidade de execução antecipada da pena. Questionava-se o disposto no art. 637 do Código de Processo Penal ("o recurso extraordinário

\footnotetext{
300 "Trago igualmente a reflexão a percuciente observação do filósofo norte-americano Ronald Dworkin, que, em sua obra Freedom's Law, sob o epíteto "conformidade e coerção", sustenta o seguinte: "Proibir o aborto não é a mesma coisa que tomar decisões coercitivas no campo do zoneamento urbano ou da proteção de espécies em perigo. O impacto em certas pessoas (mulheres grávidas) é bem maior. Uma mulher que é obrigada a levar adiante uma gravidez em razão da pressão de sua comunidade não tem mais o controle sobre o seu corpo. Isto é uma escravidão parcial, uma privação de liberdade muito mais séria do que os ônus sofridos pelos cidadãos em razão do poder de polícia do Estado em matéria urbana! Ter um filho pode significar a destruição da vida de uma mulher!". "Voto do Ministro Joaquim Barbosa, HC 84.025-6, pp. 356-357

${ }^{301}$ Disponível em: http://redir.stf.jus.br/paginadorpub/paginador.jsp?docTP=AC\&docID=608531. Acesso em 07 de dezembro de 2012.
} 
não tem efeito suspensivo, e uma vez arrazoados pelo recorrido os autos do translado, os originais baixarão à primeira instância para a execução da sentença") face ao art. $5^{\circ}$, inciso LVII, da Constituição Federal ("ninguém será considerado culpado até o trânsito em julgado da sentença penal condenatória"). Nesse sentido, pleiteava-se, no referido habeas corpus, que o paciente ficasse em liberdade até o trânsito em julgado do seu Recurso Extraordinário, não se aplicando o disposto no art. 637 do Código de Processo Penal, face à sua contrariedade à norma constitucional insculpida no art. $5^{\circ}$, inciso LVII.

O Supremo Tribunal Federal decidiu, por maioria de votos, conceder a ordem pleiteada no habeas corpus.

O Ministro Menezes Direito divergiu da posição vencedora, em seu voto, defendendo a impossibilidade de se atribuir interpretações conflitantes quanto à aplicação do princípio de presunção de inocência, insculpido no art. $5^{\circ}$, inciso LVII, da Constituição Federal. O ministro defende que se é admitida a prisão, antes do trânsito em julgado, enquanto medida cautelar, não faria sentido entender que ela não seria cabível, quando já há uma condenação, estando pendente apenas Recurso Extraordinário, conforme a hipótese que versa o habeas corpus ora em análise. $\mathrm{O}$ ministro argumenta que, embora reconheça que os princípios, conforme ensina a lição de Dworkin, não sigam a ideia do "tudo ou nada", há um dever de aplicá-los de maneira coerente a casos que envolvam o mesmo conflito ${ }^{302}$. Dworkin realmente defende, em sua teoria (Capítulo II.3.1.

302 "Os princípios, segundo está no magistério de Dworkin, não seguem a ideia do "tudo ou nada"; ora se aplicam, ora não (Taking Rights Seriously. Cambridge: Harvard University Press, 1978, pág. 24). Mas isso não quer dizer que possam ser aplicados de forma discriminatória a situações que envolvam o mesmo conflito. Não é possível dizer que a privação da liberdade antes do trânsito em julgado ora viola ora não viola o princípio da inocência. (...) se essas situações são as mesmas, a posição tomada não pode ser variável. Nessa discussão, não vejo diferença entre a prisão em decorrência de uma faculdade processual e a prisão decorrente da aplicação da lei penal. Ambas envolvem a privação de liberdade do acusado e, a se erigir a norma do art. $5^{\circ}$, LVII, em uma absoluta aplicação da presunção 
desta dissertação), que há um dever de coerência por parte do intérprete-juiz, na aplicação dos princípios, ao decidir casos sobre o mesmo conflito, na medida em que se deve respeitar a equidade dos jurisdicionados, os quais não podem ser tratados de maneira diferenciada pelo Judiciário, quando em situações preponderantemente semelhantes. O ministro Menezes Direito acolhe essa visão de Dworkin em seu voto divergente.

A esse respeito, apenas a título ilustrativo, esclarece-se que é possível defender a posição de que não se trata de situações semelhantes (prisão cautelar e prisão antes do trânsito em julgado) e, por essa razão, não se justificaria o tratamento equitativo com base na teoria de Dworkin, que determina a equidade na aplicação de princípios a casos, preponderantemente, semelhantes. Um argumento forte a esse respeito é o fato da prisão cautelar apenas ser possível em situações excepcionalíssimas, em que estão em jogo a garantia da ordem pública, da ordem econômica, a instrução criminal, ou o asseguramento da aplicação da lei penal ${ }^{303}$, por isso, não seria semelhante ao caso da prisão antes do trânsito em julgado, ao qual não estaria sujeito a essas condições, aplicando-se a todos os casos, independentemente, de qualquer condição. Sob essa perspectiva, não deveria ter sido evocado o princípio da equidade na aplicação dos princípios enunciados na teoria de Dworkin, porque se tratam de situações diferentes.

(vi.) O sexto caso trata-se de Medida Cautelar em Ação Direta de Inconstitucionalidade n. ${ }^{\circ} 4.264 / \mathrm{PE}^{304}$, de relatoria do Ministro Ricardo

de inocência, ambas não deixariam de constituir a sua violação.” Voto do Ministro Menezes Direito, HC 84.078-7/MG, p. 1103

303 Art. 312 do Código de Processo Penal: “A prisão preventiva poderá ser decretada como garantia da ordem pública, da ordem econômica, por conveniência da instrução criminal, ou para assegurar a aplicação da lei penal, quando houver prova da existência do crime e indício suficiente de autoria."

304 Disponível em: http://redir.stf.jus.br/paginadorpub/paginador.jsp?docTP=AC\&docID=623508. Acesso em 07 de dezembro de 2012. 
Lewandowski, proposta pela Mesa da Assembleia Legislativa do Estado de Pernambuco, na qual se pleiteava, cautelarmente, a declaração de inconstitucionalidade do art. 11 do Decreto-lei n. ${ }^{\circ}$ 9.760/1946 ${ }^{305}$, conforme a redação dada pelo art. $5^{\circ}$ da Lei n. ${ }^{\circ} 11.481 / 2007^{306}$. A alteração legislativa questionada retirou a possibilidade de citação pessoal dos interessados acerca da demarcação das linhas do preamar médio do ano de 1831 e da média das enchentes ordinárias, a qual passaria a ser feita apenas por edital, o que violaria o devido processo legal, assegurado pelo Constituição Federal no art. $5^{\circ}$, inciso LIV ("ninguém será privado da liberdade ou de seus bens sem o devido processo legal").

Os Ministros do Supremo Tribunal Federal, em julgamento realizado em 16 de março de 2011, por maioria de votos, deferiram a Medida Cautelar pleitada.

O Ministro Luiz Fux, cujo voto sagrou-se vencedor, menciona Dworkin ao afirmar que o direito à propriedade é um direito a ser levado a sério $^{307}$, portanto, deveria ser respeitado o devido processo legal, consubstanciado no direito à ampla defesa e ao contraditório, ao serem feitas

305 Redação antes da alteração promovida pela Lei questionada: “Art. 11. Para a realização do trabalho, o S.P.U. convidará os interessados, certos e incertos, pessoalmente ou por edital, para que no prazo de 60 (sessenta) dias ofereçam a estudo, se assim lhes convier, plantas documentos e outros esclarecimentos concernentes aos terrenos compreendidos no trecho demarcado." (g.n.)

306 “Art. 11. Para a realização da demarcação, a SPU convidará os interessados, por edital, para que no prazo de 60 (sessenta) dias ofereçam a estudo plantas, documentos e outros esclarecimentos concernentes aos terrenos compreendidos no trecho demarcando. (Redação dada pela Lei ${ }^{\circ}$ 11.481, de 2007).” (g.n.)

307 "Um Estado Democrático de Direito, como é o caso do Estado brasileiro, por imperativo do que disposto em nossa Carta de 1988, deve observar alguns princípios fundamentais, tais como os estampados no artigo $1^{\circ}$ da Constituição da República. Sem ter a pretensão de, neste voto, discorrer sobre quais princípios são indispensáveis e um Estado de Direito, resta incontroverso, que a cidadania deve ser garantida para que um Estado seja reconhecido como tal. E, nesse contexto, a cidadania plena exige a observância do devido processo legal, isto é, de uma efetivo direito ao contraditório e à ampla defesa, especialmente quando se está diante de uma privação ao direito de propriedade. O direito fundamental à propriedade é, parafraseando o filósofo do Direto norteamericano Ronald Dworkin, um direito a ser levado a sério! (In Taking Right Seriously, Cambridge: Harvard University Press, 1977)" Voto do Ministro Luiz Fux, MC ADI 4.264/PE, p. 79. 
demarcações as quais afetam este direito de propriedade. A citação por edital, nesse sentido, seria violadora do devido processo legal e, portanto, seria inconstitucional. Não se irá alongar, aqui, com considerações outras sobre a menção do Ministro, até mesmo porque ela é bastante pontual ao mencionar a ideia, que deu nome a uma das obras de Dworkin ${ }^{308}$, a respeito de se levar os direitos a sério. De qualquer modo, não se nega que ela é útil para evidenciar o prestígio das ideias de Dworkin no Supremo Tribunal Federal, o qual é um dos propósitos deste Capítulo.

(vii.) O último caso que aqui se irá tratar são os Mandados de Segurança 26.602/DF; 26.603/DF, e 26.604/DF ${ }^{309}$, de relatoria, respectivamente, do Ministro Eros Grau, do Ministro Celso de Mello e da Ministra Cármen Lúcia, impetrados por partidos políticos (PPS, PSDB e DEM), que questionavam ato do Presidente da Câmara dos Deputados, que indeferira requerimento para declaração de vacância dos mandatos exercidos por Deputados Federais, que se desfiliaram dos referidos partidos, sob o argumento de restar ferida a fidelidade partidária, conforme estabelecido pelo Tribunal Superior Eleitoral, na consulta n. ${ }^{\circ} 1.398$, respondida em 27 de março de 2007.

O Supremo Tribunal Federal, em julgamento realizado em 4 de outubro de 2007, por maioria de votos, conheceu do Mandado de Segurança e denegou a ordem pleiteada, considerando que os Deputados Federais, em questão, mudaram de partido, antes da resposta da consulta ao Tribunal Superior Eleitoral, e apenas a partir da qual passou-se a vigorar o instituto da fidelidade partidária.

${ }^{308}$ DWORKIN, Ronald. Levando os direitos a sério, cit.

${ }^{309}$ Disponível em: http://redir.stf.jus.br/paginadorpub/paginador.jsp?docTP=AC\&docID=555539. Acesso em: 7 de dezembro de 2012. 
O Ministro Menezes Direito menciona Dworkin, em seu voto ${ }^{310}$, para defender a relevância da fidelidade partidária, a partir de uma leitura moral da Constituição proposta por Dworkin. Ele defende que este método de interpretação constitucional mostra-se mais adequado que uma análise apenas histórica, gramatical e sistemática da Constituição, conforme orienta o método tradicional de interpretação. Deve-se, portanto, interpretar os dispositivos relativos aos direitos políticos (por exemplo, aquele que estabelece as condições de elegibilidade e, dentre elas, elenca a obrigatoriedade da filiação partidária art. $14, \S 3^{\circ}, \mathrm{V}, \mathrm{CF}-$; o que obriga os partidos políticos a prestarem contas da campanha eleitoral - art.17, III, CF - dentre outros); em uma visão conjunta que dá unidade à Constituição e a todos os seus dispositivos. Nesse sentido, o voto do Ministro Menezes Direito mostra-se bastante alinhado às ideias propostas na teoria de Dworkin, na visão do Direito como integridade, segundo o qual devese interpretar os direitos e deveres do cidadãos, com uma perspectiva ampla de toda a prática jurídica da comunidade, em uma visão não limitadora e autônoma dos dispositivos legais, procurando-se sempre enxergá-los sob sua melhor luz diante do conjunto. A leitura moral da Constituição, proposta por Dworkin, e defendida pelo Ministro Menezes Direito, em seu voto, revela esse apreço e necessidade de se enxergar os dispositivos constitucionais sob a sua melhor luz, tanto enquanto uma técnica adequada à interpretação constitucional, como também uma forma de legitimar, verdadeiramente, o Estado de Direito que se quer ter.

Concluída a análise dos setes casos que se propôs discutir, esperase que tenha restado clara a relevância e influência que as ideias defendidas por Dworkin, em sua teoria, exercem nos ministros da mais alta Corte brasileira ao elaborar seus votos. Além disso, cumpre ressaltar que os casos nos quais os ministros citam Dworkin são bastante paradigmáticos no direito constitucional

310 Voto do Ministro Menezes Direito, nos referidos Mandados de Segurança, pp. 237-239 
brasileiro recente, por exemplo, o tratamento às uniões homoafetivas; a lei de imprensa; as pesquisas com células-tronco embrionárias; o aborto de feto anencefálico; a questão da fidelidade partidária etc. A análise casuística, que aqui se empreendeu, auxilia no destaque de alguns pontos altos da teoria apresentada nos Capítulos anteriores, como o dever do Estado de tratar as pessoas com igual consideração; o Direito como integridade; a interpretação dos valores de maneira integrada (não-autônoma); a questão da leitura moral da Constituição, dentre outros temas que foram aqui considerados. 


\section{CONCLUSÃo}

Nesta dissertação, procurou-se desenvolver questões atinentes à legitimidade e à decisão dos casos difíceis, conforme teoria proposta por Ronald Dworkin. Para tanto, passou-se pelos pontos teóricos centrais que esta temática exige $^{311}$ e, como ilustração prática, da teoria desenvolvida, bem como da relevância do tema e do autor escolhidos, foi realizada uma análise focalizada de julgados do Supremo Tribunal Federal.

As decisões sobre os casos difíceis, conforme se pôde constatar, envolve muitos aspectos polêmicos quanto à possibilidade do juiz ser mais criativo ou, estritamente, conservador, em suas funções institucionais; aos limites da atividade jurisdicional, para que ela continue legitima. Enfim, todas essas questões são de suma relevância, no contexto atual, que se vivencia, na medida em que se revela a necessidade de se desenvolver teorias consistentes para lidar com esses temas de maneira apropriada e abrangente. Nesse sentido, as teorias devem ser capazes de lidar tanto com as técnicas de decisão, como embrenhar-se na difícil tarefa de legitimar o que se propõe, sem desvincular-se da realidade da prática jurídica.

Dworkin esforça-se nessa direção. Propõe uma união entre teoria e prática, alia a sua teoria do Direito à teoria da decisão judicial, conforme se evidenciou no Capítulo II.2., de modo que, diferentemente dos adeptos das escolas analíticas do Direito (e.g.,Hart), não constrói a sua teoria geral focada na ideia de validade das normas (e.g., regra de reconhecimento), ao revés, foca-se na interpretação destas. O Direito, para Dworkin, é um conceito interpretativo,

${ }^{311}$ O conceito de direito para Ronald Dworkin (Capítulo II.1.); a teoria da decisão judicial por ele proposta (Capítulo II.2.); a decisão nos casos difíceis (Capítulo II.3.); a concepção de Estado de Direito e o papel a ser desempenhado pelos juízes (Capítulo III.1.); o problema da coerção nos casos controversos (Capítulo III.2.); a eventual violação da Democracia pela teoria por ele proposta (Capítulo III.3.); e os modelos de comunidade política e a questão da legitimidade (Capítulo III.4). 
que ganha sentido na prática jurídica, na sua aplicação. Ele dirige seu esforço teórico a resolver os problemas que essa prática demanda, foca-se na aplicação, uma vez que a interpretação, que se realiza com este processo, revela o que o próprio Direito é. A questão dos casos difíceis emerge nesse contexto interpretativo. Considerando que o presente trabalho versa sobre a resolução destes casos na teoria de Dworkin, tanto pela perspectiva da decisão, quanto de sua legitimidade, rememora-se, neste fechamento, algumas ideais-chave trabalhadas ao longo desta dissertação.

No que se refere aos casos fáceis e difíceis, esclarece-se que, nos casos fáceis, as decisões judiciais se baseiam em uma lei, ou precedente claros, cuja aplicação é indubitável. Estas decisões, para Dworkin, são justificadas somente por argumentos de princípio e não há margens para indagações de ordem política, ainda que o fundamento da criação da referida lei seja alguma política. Por outro lado, nos casos difíceis, em que não há uma regra, ou precedentes, claros a serem aplicados aos fatos descritos pelas partes, a decisão poderia, ao menos em tese, fundamentar-se tanto em argumentos de princípio, como em argumentos de política.

Para ilustrar essa afirmação, conforme mencionado nesta dissertação, Dworkin refere-se ao caso Spartan Steel \& Alloys Ltd vs. Martin \& $\mathrm{Co}^{312}$. Afirma que a decisão do tribunal poderia ter se baseado tanto no eventual direito à indenização por parte do autor - argumento de princípio - como poderia ter se baseado em um fundamento econômico, que seria dividir a responsabilidade pelo acidente entre a companhia de eletricidade e a ré argumento de política. Para fundamentar uma decisão com base em um argumento político seria necessário pressupor a função de legisladores exercida pelos Tribunais, o que não é aceito na teoria formulada por Dworkin, a qual

312 Este caso é tratado no Capítulo II.2. A teoria da decisão judicial de Ronald Dworkin 
entende que as decisões judiciais, nos casos cíveis difíceis, como o Spartan Steel, devem se fundamentar, precipuamente, em argumentos de princípio, porque os juízes não são legisladores delegados. Portanto, a afirmação de que aos juízes é permitido fazer juízos, como os políticos, ao resolver casos difíceis não encontra guarida na teoria proposta por Dworkin.

A esse respeito, Dworkin esclarece que as decisões fundamentadas em argumentos políticos levantam duas objeções centrais, quanto à legitimidade, quais sejam, (i) a de que o Direito deve ser criado por autoridades eleitas, que representariam a comunidade política que as elegeram; e (ii) a de que o juiz, ao fundamentar sua decisão em um suposto direito, até então inexistente, prejudicaria a parte sucumbente, tendo em vista que a esta seria o negado o direito de se planejar e antever os riscos que corria com a prática de determinada conduta, uma vez que o direito é criado pelo juiz após o fato. Essas objeções foram desenvolvidas ao longo desta dissertação, em especial, no Capítulo III.2. referente à coerção nos casos controversos.

Dworkin esclarece que as decisões judiciais devem ter coerência com a história institucional, em um sentido especial, que seria a coerência na aplicação do princípio no qual se assenta determinada decisão ${ }^{313}$. Essa história institucional é construída em conjunto por cada funcionário da justiça que dá sua contribuição de forma coerente, isto é, em harmonia com a legislação e com a história daquele país.

Na concepção de Dworkin, essa coerência é a diretriz para que os intérpretes do Direito, em especial os juízes no seu ato decisório, identifiquem direitos e deveres legais (Capítulo II.3.3. Direitos institucionais e jurídicos),

313 "Coerência aqui significa, por certo, coerência na aplicação do princípio que se tomou por base, e não apenas na regra específica anunciada em nome desse princípio.” DWORKIN, Ronald. Levando os direitos a sério, cit., p. 139 
tomando como pressuposto que o Direito forma-se por meio da comunidade personificada, sua única autora, a qual expressa uma concepção coerente de justiça e equidade.

O Direito como integridade, formulado por Dworkin, é essencialmente interpretativo, produto da interpretação ampla da prática jurídica da comunidade, exigindo-se dos juízes contínua interpretação das normas, em especial na resolução de casos difíceis. É um processo construtivo dessa melhor interpretação.

Neste ponto, Dworkin diferencia o Direito como integridade, essencialmente interpretativo, do convencionalismo e do pragmatismo (Capítulo II.1.1 Direito como integridade vs. Convencionalismo e Pragmatismo Jurídico). O convencionalismo, de acordo com a concepção de Dworkin, exige um profundo estudo dos juízes dos repertórios jurídicos e dos registros parlamentares, para que possam aferir as intenções proferidas pelas instituições a que se atribui o poder de legislar. O convencionalismo volta-se para o passado, neste processo de aferimento das intenções do Poder Legislativo. Por outro lado, o pragmatismo, no entendimento de Dworkin, exige uma instrumentalização do pensamento dos juízes voltada para o futuro; a sua decisão não considera o passado, prescinde de toda a construção histórica daquela comunidade política, foca-se em consequências desejáveis no futuro.

Essas concepções são incompletas, segmentam o processo interpretativo a um período temporal específico, não conseguem compreender o Direito como um todo íntegro (passado/presente/futuro). O Direito como integridade, em contrapartida, constrói-se pela interpretação ampla da prática jurídica, sendo tanto produto desta interpretação, como sua fonte inspiradora. 
Na concepção de Dworkin, a integridade ${ }^{314}$ (Capítulo II.1.) não exige coerência em todos os períodos históricos do Direito em uma comunidade, mas exige uma coerência voltada para o conjunto de princípios das decisões coletivas tomadas no passado, não se limitando ao seu conteúdo explícito. Assim, ao retornar ao passado não se pretende resgatar os ideais políticos e as intenções concretas dos criadores daquelas normas, ou dos juízes que formularam determinado precedente, mas de se compreender a história geral, os princípios gerais implícitos naquelas normas ou decisões a que se recorre. Em outras palavras, a integridade exige coerência de princípios, não às intenções práticas dos legisladores ou juízes do passado para, respectivamente, legislarem ou decidirem de uma forma ou de outra.

Ao se falar em integridade, Dworkin desenvolve a ideia de romance em cadeia, na qual os indivíduos do passado e do presente desenvolvem progressivamente uma moralidade constitucional coerente e harmônica. No romance em cadeia, Dworkin faz uma analogia entre o Direito e a literatura, e desenvolve a ideia de que cada romancista da cadeia interpreta os capítulos já escritos e escreve novos capítulos, passando adiante o romance. Todos os romancistas procuram desenvolver o romance da melhor forma, dando a ele a melhor interpretação, coerência e continuidade. O romancista deve ter em mente um só romance e para isso deve analisar cuidadosamente o material que recebeu, desenvolver a sua parte e a partir dela possibilitar o

${ }^{314}$ Dworkin desenvolve o conceito de integridade em várias dimensões, quais sejam, "em primeiro lugar, insiste em que a decisão judicial seja determinada por princípios, não por acordos, estratégias ou acomodações políticas. Essa exigência aparentemente banal é muitas vezes ignorada. A posição atual da Suprema Corte sobre a questão sensível da ação afirmativa, por exemplo, não pode ser justificada por nenhum conjunto coerente de princípios, por mais conservador ou monótono que seja. Em segundo lugar, aplica-se verticalmente: se um juiz afirma que um determinado direito à liberdade é fundamental, deve demonstrar que sua afirmação é coerente com todos os precedentes e com as principais estruturas de nosso arranjo constitucional. Em terceiro lugar, a integridade se aplica horizontalmente: um juiz que aplica um princípio deve dar plena importância a esse princípio os outros pleitos que decide ou endossa." DWORKIN, Ronald. O direito da liberdade: A leitura moral da Constituição norte-americana. cit., p. 133 
desenvolvimento do romance pelos seus sucessores, de modo a ser um todo tão coerente que pareça obra de um único romancista.

Assim, o autor, ao desenvolver este romance coerente, deve se atentar a duas dimensões, quais sejam, a adequação e a interpretação.

A dimensão da adequação, na teoria de Dworkin, relaciona-se ao fato do romancista não poder adotar interpretação que seja incoerente com o texto que lhe foi entregue, considerando os componentes do romance, como os personagens, trama, tema e objetivo etc. Não é necessário que a interpretação do romancista seja aderente a cada parte do texto que lhe foi entregue, mas deve fazer sentido com o texto como um todo.

A dimensão da justificação, de acordo com a teoria proposta por Dworkin, exige que o romancista decida entre as diversas leituras possíveis do texto, escolhendo aquela que corresponda a melhor leitura em conjunto com a obra em desenvolvimento. Nesse processo de julgamento da melhor leitura, vários fatores o compõem, como o juízo estético do romancista sobre a importância e beleza de cada uma das leituras, bem como qual melhor corresponde às expectativas daquilo que o romance deveria expressar. ${ }^{315}$

Os diversos juízos necessários à realização do processo de desenvolvimento do texto, que se consubstancia em uma constante disputa entre opiniões textuais e substantivas, é o que, no entendimento de Dworkin, distingue o romancista em cadeia de um produtor literário mais criativo e independente.

315 DWORKIN, Ronald. O império do direito, cit., p. 278 
Para elucidar o Direito como integridade, a partir desta ideia de romance em cadeia, Dworkin afirma que o juiz, ao decidir um caso difícil, deve consultar as decisões de outros juízes proferidas em casos semelhantes, considerando-as como parte de uma longa história, em que ele tem de interpretar e continuar, de acordo com o entendimento mais adequado ao texto que lhe foi entregue e ao caso que se apresenta. Assim, o Direito como integridade não permite que os juízes extraiam das normas qualquer juízo moral particular, ainda que isso lhes pareça correto. Esse juízo deve ser coerente com o desenho estrutural da legislação, bem como com a interpretação dada a ela pelos juízes do passado. O juiz, que consegue desempenhar esta função da forma proposta por Dworkin, é o juiz Hércules, figura mítica por ele reverenciada em sua obra, com paciência e capacidade sobre-humanas.

Os juízes humanos, que não são Hércules, para Dworkin, devem procurar aproximar-se da figura desse juiz mítico, decidindo sempre com responsabilidade, nos termos acima apresentados, porque esta seria a melhor forma de encontrar a resposta certa (Capítulo II.3.4.). Ainda sobre esta questão, esclarece-se que esse agir com responsabilidade assume uma relevância muito grande na questão da legitimidade das decisões dos agentes de poder, os juízes, os legisladores, diretores de agências reguladoras, dentre outras posições, cujas decisões impactam a vida do cidadão, pois vêm revestidas da coerção estatal.

A questão da coerção estatal e sua legitimidade, conforme esclarecido nesta dissertação, dependem da maneira como se concebe o Estado de Direito, pode-se entendê-lo (i) por um modelo centrado nas regras, segundo o qual apenas as regras positivadas legitimam uma decisão judicial; ou (ii) por um modelo centrado no Direito, de acordo com o qual é possível considerar elementos extrínsecos à norma positivada, como a moralidade política da comunidade, por exemplo, para fundamentar uma decisão judicial. Este último 
modelo de Estado de Direito é o defendido na teoria proposta por Dworkin e, nestes termos, justifica o uso de uma legítima coerção estatal.

Outro ponto que merece destaque, nas considerações finais deste trabalho, é questão da eventual violação da Democracia na teoria do Direito proposta por Dworkin, a qual atribui aos juízes um papel contra-majoritário, submetidos aos princípios (positivados, ou não) que regem a comunidade política, e não à vontade das maiorias eventuais. Se a Democracia for concebida, enquanto governo da maioria (premissa majoritária), realmente justifica-se esta preocupação; por outro lado, se for considerada enquanto uma obrigação de tratar todos com igual consideração, não há violação com as decisões judiciais, que visam resguardar esta igualdade mesmo que em contrariedade à vontade da maioria (concepção constitucional de Democracia).

Reitera-se que a teoria de Ronald Dworkin pode ser considerada por muitos enquanto uma teoria reacionária, que atribui mais poderes ao Judiciário, do que ele realmente deveria ter. Todavia, esta visão demonstrou-se equivocada ao longo deste trabalho. Primeiro, porque Dworkin, expressamente $^{316}$, não é adepto do ativismo judicial, afirma inclusive que esta é uma forma virulenta de pragmatismo jurídico; segundo, porque ele orienta a sua teoria naquilo que há de mais perene na comunidade que é moralidade política desta; terceiro, porque propõe uma Democracia em bases constitucionais, as quais impedem que reine a vontade das maiorias eventuais, que podem atentar contra membros minoritários da comunidade política, o que a história mostra não ser desejável, ou sequer aceitável (e.g. Holocausto promovido pelo nazismo).

Por fim, pode-se dizer, a partir de tudo que foi aqui discutido, que

${ }^{316}$ DWORKIN, Ronald. O império do direito, cit., p. 452 
a teoria de Dworkin deixa a lição de que o apego à regra, em um grau que conduza a uma irreflexão absoluta, produz decisões ruins ou sequer pode ser capaz de produzir decisões nos casos difíceis. A subsunção é mecânica, ao contrário dos direitos, na teoria proposta por Dworkin, os quais são oriundos de um processo interpretativo mais complexo, que exige considerações outras que não apenas o que está expresso na letra da lei.

Nesse sentido, pode-se dizer que o mecanicismo proposto por um jogo de validade, em que as funções de cada um dos Poderes são, absolutamente, distintas, sem qualquer zona de intersecção, que o malfeito de um dos Poderes atinja a atividade do outro, que reproduz o mesmo malfeito, e assim por diante, não deve imperar em um Estado de Direito sério. A cadeia deve ser mantida, mas o seu elo vicioso tem de ser quebrado, os malfeitos devem ser controlados e o Judiciário tem um papel fundamental nesta questão, especialmente, no que se refere ao tratamento a todos com igual consideração, freando os ímpetos repressores da maioria e colocando as coisas nos seus devidos eixos. Por sua vez, parece bastante equivocado presumir que o Judiciário não deva ser controlado. É claro que, em um Estado de Direito, em uma comunidade política verdadeira, todos os Poderes e todos os cidadãos (aqui entendidos como membros da comunidade, independentemente do status que o governo a eles atribua) devem controlar os atos de todos e denunciar qualquer tentativa de solapar os princípios da comunidade, seja por particulares, ou pelos Poderes constituídos. Porque só há legitimidade, conforme explanado no Capítulo III.4, de qualquer ato de governo, lei, ou decisão judicial, se todos forem tratados com igual consideração. Se esta regra de ouro, que é o verdadeiro sentido da Democracia proposta por Dworkin, for quebrada, não há legitimidade e as pessoas não podem ser coagidas a cumprir o que se estabeleceu pelo legislador, pelo juiz, ou por quem quer que seja. 


\section{BIBLIOGRAFIA}

AARNIO,Aulis. The rational as reasonable, Dordrecht: D. Reidel Publishing Company, 1987

ALEXY, Robert. Teoria de los derechos fundamentales, Madrid, Centro de Estudios Constitucionales, 1993

ALTMAN, Andrew. Legal Realism, Critical Legal Studies, and Dworkin, Philosophy \& Public Affairs, vol. 15, n. ${ }^{\circ}$ 3, Princeton: Princeton University Press, 1986

APPIO, Eduardo. Direito das minorias, São Paulo, Revista dos Tribunais, 2008

BERLIN, Isaiah. Quatro ensaios sobre a liberdade. Brasília, Editora Universidade de Brasília, 1981

BIX, Brian. Jurisprudence Theory and Context, 5a ed., London: Sweet \& Maxwell Ltd., 2009

BLACKBURN, Simon. Spreading the word: grounding in the philosophy of language, Oxford University Press, 1984

BOBBIO, Norberto. Qual democracia ?, São Paulo, Edições Loyola, 2009

BOITEUX, Elza Antonia Pereira Cunha. A função ética da pena, Tese de livredocência em Filosofia e Teoria Geral do Direito, Universidade de São Paulo, 2010 
O significado perdido da função de julgar, Tese de doutorado em direito, Universidade de São Paulo, São Paulo, 1990

BONAVIDES, Paulo. Curso de Direito Constitucional. 15a ed., São Paulo, Malheiros, 2004

BRIETZKE, Paul H. Dworkin today, Valparaiso University Law Review, vol. $21, n^{\circ} .2,1987$

CALSAMIGLIA, Albert. El concepto de integridad en Dworkin, Doxa: Cuadernos de Filosofía del Derecho, núm. 12, 1992 - ¿Por qué es importante Dworkin?, Doxa: Cuadernos de Filosofía del Derecho, nº 2, 1985

CAPPELLETTI, Mauro. Juízes Legisladores?, trad. Carlos Alberto Alvaro de Oliveira, Porto Alegre: Sérgio Antonio Fabris Editor, 1999

CHEMERINSKY, Erwin. Racionalizing the abortion debate: legal rethoric and abortion controversy, Buffalo Law Review, vol. 31, 1982

DASCAL, Marcelo. Leibniz's two-pronged dialetic, In: DASCAL, Marcelo (ed.), Leibniz: what kind of rationalist?, Logic, espistemologic, and the unity of science, vol. 13, Springer, 2008

DELTORO, Pablo de Lora. La interpretación originalista de la constitución: una aproximación desde la fiolsofia Del derecho, Madrid, Centro de Estudios Políticos y Constitucionales, 1998 
DE MIRANDA, Pontes. Comentários à Constituição de 1946. 3a ed., Tomo III, Rio de Janeiro, Editor Borsoi, 1960

DIMOULIS, Dimitri. Positivismo jurídico: introdução a uma teoria do direito e defesa do pragmatismo jurídico-político, São Paulo, Editora Método, 2006

DOBROWOLSKI, Silvio. A constituição no mundo globalizado, Florianópolis, Diploma legal, 2000

DORF, Michael C. Truth, Justice, and the American Constitution. Columbia Law Review, vol. 97:133, 1997

DWORKIN, Ronald. A justiça de toga, trad. Jefferson Luiz Camargo, São Paulo, Martins Fontes, 2010

. A virtude soberana: A teoria e prática da igualdade, trad. Jussara Simões, São Paulo, Martins Fontes, 2005.

. Hard cases, Harvard Law Review, vol. 88, abril, 1975

- Hart's Postscript and the character of political philosophy, Oxford Journal of Legal Studies, vol. 24, n. ${ }^{\circ}$ 1, 2004

Justice for Hedgehogs, Belknap Press of Harvard University Press, 2011 . Levando os direitos a sério, trad. Jefferson Luiz Camargo, São Paulo, Martins Fontes, 2007. 
. O direito da liberdade: A leitura moral da Constituição norte-americana, trad. Marcelo Brandão Cipolla, São Paulo, Martins Fontes, 2006.

. O império do direito, trad. Jefferson Luiz Camargo, São

Paulo, Martins Fontes, 2007.

. Uma questão de princípio, trad. Luís Carlos Borges, São

Paulo, Martins Fontes, 2005.

The model of rules, University of Chicago Law Review,

vol. 35,1967

What is equality? Part 3: the place of liberty, Iowa Law

Review, vol. 73, 1987

EISELE, Thomas D. Taking our actual constitution seriously, Michigan Law Review, vol. 95, 1997

ELY, John H. Democracy and distrust: a theory of judicial review, Harvard University Press, 1980

The ages of crying wolf: a comment of Roe vs. Wade, Yale law Journal, vol. 92, 1973

ENTERRÍA, Eduardo Garcia de. La constitución como norma y el tribunal 
constitucional, Madrid, Civitas Ediciones, 2001

FARALLI, Carla. A Filosofia contemporânea do Direito. Temas e Desafios, São Paulo, Martins fontes, 2006

FARIA, José Eduardo. O modelo liberal de direito e Estado. In: José Eduardo Faria (Org.), Direito e Justiça: a função social do judiciário, 3a edição, São Paulo, Editora Ática, 1997

FERRAZ JUNIOR, Tércio Sampaio. O Judiciário frente à divisão dos Poderes: um princípio em decadência?. Revista USP - Dossiê Judiciário, São Paulo, v. 21, 1994

Introdução ao Estudo do Direito. Técnica,

Decisão e Dominação, $4^{\text {a }}$ ed., São Paulo, Atlas, 2003

FISH, Stanley. Fish v. Fiss in Interpreting law and literature: a hermeneutic reader, Sanford Levinson \& Steve Mailloux editores, 3a edição, Illinois, Northwestern Univesity Press, 1991

FULLER, Lon. L. Positivism and Fidelity to Law: A Reply to Professor Hart. Harvard Law Review, vol. 71, nº. 4, Feb., 1958

GARCÍA, Eusebio Fernández. La obediencia al derecho, Madrid, Editorial Civitas S.A., 1987

GIBBARD, Allan. Wise choices, apt feelings, Harvard University Press, 1992

GRAU, Eros Roberto. Ensaio e discurso sobre a interpretação/aplicação do 
direito. 4a edição, São Paulo, Malheiros, 2006

. O direito posto e o direito pressuposto. 8a. edição, São

Paulo, Malheiros, 2011

GRIFFITHS, John. The Politics of the Judiciary. Nova Iorque: Fontana Books, 1977

GUEST, Stephen. Ronald Dworkin, 3a edição, Stanford, Stanford University Press, 2012

HÄBERLE, Peter. Hermenêutica Constitucional - A sociedade aberta dos intérpretes da Constituição: Contribuição para a interpretação pluralista $e$ 'procedimental' da Constituição. Trad. Gilmar Ferreira Mendes, Sergio Antonio Fabris Editor, 1997

HABERMAS, Jürgen. Direito e democracia: entre facticidade e validade, vol. I, trad. Flávio Beno Siebeneichler, Rio de Janeiro, Tempo Brasileiro, 1997

- Reconciliation through the public use of reason:

remarks on John Rawl's Political Liberalism, vol. 92, 1995

HAND, Learned. The Bill of Rights. Harvard University Press, 1958

HANSON, Robert. Objective decision making in Lonergan and Dworkin, Boston College Law Review, vol. 44, 2003

HARE, R. M. The language of morals, Oxford University Press, 1952 
HART, H. L. A.O conceito de Direito, trad. Antônio de Oliveira Sette-Câmara, São Paulo, Martins Fontes, 2009

HUNT, Alan. Reading Dworkin Critically, New York: Oxford, Berg, 1992

JOYCE, Richard. The Myth of Morality, Cambridge University Press, 2001

KATZ, Leo. Incommensurable choices and the problem of moral ignorance, University of Pennsylvania Law Review, vol. 146, n. ${ }^{\circ}$, junho, 1998

KELBLEY, Charles. Makers and receivers: judicial heresy and the tempting of America, Fordham Urban Law Journal, vol. 18, Issue 1, Article 3, 1990

KLATAU FILHO, Paulo de Tarso Dias. Igualdade e liberdade: Ronald Dworkin e a concepção contemporânea de direitos humanos, Belém, Cesupa, 2004

LAFER, Celso. A legitimidade na correlação Direito e Poder: uma leitura inspirada no tridimensionalismo jurídico de Miguel Reale. In: Miguel Reale: Estudos em homenagem a seus 90 anos, Porto Alegre, EDIPUCRS, 2000

A Constituição de 1988 e as relações internacionais- reflexões sobre o art. $4^{\circ}$ in A internacionalização dos direitos humanos: Constituição, racismo e relações internacionais, Barueri, Manole, 2005

A reconstrução dos Direitos Humanos. Um diálogo com o pensamento de Hannah Arendt. São Paulo, Cia das Letras, 1988

. Filosofia do direito e princípios gerais: considerações sobre a 
pergunta 'O que é a Filosofia do Direito?'. In: Alaôr Caffé Alves e outros. (Org.). O que é a Filosofia do Direito?, Barueri, Manole, 2004

. O moderno e o antigo conceito de liberdade, In: Ensaios sobre a liberdade. São Paulo, Perspectiva, 1980

LEITER, Brian. Beyond the Hart/Dworkin debate: The methodology Problem in Jurisprudence, American Journal of Jurisprudence, vol. 48, 2003

LIPKIN, Robert Justin. Indeterminacy, justification and truth in constitutional theory, Fordham Law Review, vol. 60, 1992

LYONS, David. As regras morais e a ética, Campinas, Papirus, 1990

MACEDO JUNIOR, Ronaldo Porto. Do xadrez à cortesia: Dworkin e a teoria do direito contemporânea, Tese de livre-docência em Filosofia e Teoria Geral do Direito, Universidade de São Paulo, 2012

MARANHÃO, Juliano Souza de Albuquerque. Positivismo Jurídico Lógicoinclusivo. Tese de livre-docência em Filosofia e Teoria Geral do Direito, Universidade de São Paulo, 2010

MARMOR, Andrei, Interpretation and legal theory, $2^{\mathrm{a}}$ edição revista, Oxford, Hart Publishing, 2005

MACCORMICK, Neil. Argumentação Jurídica e Teoria do Direito, São Paulo, Martins Fontes, 2006

H.L.A. Hart, 2a. ed., Stanford, Stanford University 
Press, 2008

MCCONNELL, Michael W. The Importance of humildity in judicial review: a comment on Ronald Dworkin's Moral Reading of the Constitution, Fordham Law Review, vol. 65, 1997

MICHELMAN, Frank, On protecting the poor through the fourteenth amendment, Harvard Law Review, vol. 83, 1969

MILLER, Jeremy M., Law's Empire: Book Review, Campbell Law Review, vol. 9, 1986

MINOW, Martha; SINGER, Joseph W. In favor of foxes: pluralism as a fact and aid to the pursuit of justice, In: Symposium Justice for Hedgehogs: conference on Ronald Dworkin forthcoming book (special issue), Boston University Law Review, vol. 90, n. ${ }^{\circ}$, abril, 2010

MOORE, Michael S. Four Reflections on Law and Morality. William and Mary Law Review, vol. 48, 2007

PATTERSON, Dennis. Law and Truth, Oxford, Oxford University Press, 1996

PÉREZ LUÑO, Antonio Enrique, Derechos humanos, estado de derecho y constitución, Madrid, Tecnos, 1984

POSNER, Richard A., Legal reasoning from the top down and from the bottom up: The Question of Unenumerated Constitucional Rights, University of Chicago law review, vol. 59, 1992 
PUTNAM, Robert, Making democracy work: civic traditions in modern Italy, Princeton University Press, 1993

RAMOS, Elival da Silva. Ativismo Judicial. São Paulo, Saraiva, 2010

RAZ, Joseph. Dworkin: a new link in the chain, California Law Review, vol. 74, 1986

Incommensurability, In: The Morality of freedom, New York, Oxford University Press, 1984

SAGER, Lawrence G, Fair measure: the legal status of underenforced constitucional norms, Harvard Law Review, vol. 91, 1978

SAGER, State courts and strategic space between norms and rules of constitucional law, Texas law review, vol. 63, 1985

SCALIA, Antonin, Originalism: The lesser evil, The University of Cincinati Law Review, vol. 57, 1989

SHAPIRO, Scott J. The "Hart-Dworkin" Debate: a short guide for the perplexed, Public law and legal theory working paper series, University of Michigan Law School, working paper n. ${ }^{\circ}$ 77, março, 2007

SMITH, Tara. Why originalism won't die - common mistakes in competing theories of judicial interpretation. Duke Journal of Constitucional Law \& Public Policy, vol. 2, 2007

SOLUM, Lawrence B. The unity of interpretation, Boston University Law 
Review, vol. 90

STEVENS, John Paul, The bill of rights: a century of progress, University of Chicago law review, vol. 59, 1992

WEST, Robin. Integrity and Universality: A comment on Ronald Dworkin's Freedom's Law, Fordham Law Review, vol. 65,1997 